Page 1 of 2 Proj. ECN

\begin{tabular}{|c|c|c|c|c|c|c|}
\hline \multirow{3}{*}{$\begin{array}{l}\text { 2. ECN Category } \\
\text { (mark one) } \\
\text { Supplemental } \\
\text { Direct Revision } \\
\text { Change ECN } \\
\text { Temporary } \\
\text { Standby } \\
\text { Supersedure } \\
\text { Cancel/Void }\end{array}$} & \multirow{3}{*}{$\begin{array}{r}{[]} \\
{[x]} \\
{[]} \\
{[]} \\
{[]} \\
{[]} \\
{[]}\end{array}$} & \multicolumn{2}{|c|}{$\begin{array}{l}\text { 3. Originator's Name. Organization. MSIN. } \\
\text { and Telephone No. } \\
\text { K. D. Daschke/Regulatory Integration } \\
\text { \& Public Involvement/R3-86/373-4781 }\end{array}$} & \multicolumn{2}{|c|}{$\begin{array}{l}\text { 3a. USQ Required? } \\
\text { [] Yes }[X] \text { No }\end{array}$} & $07 / 01 / 96$ \\
\hline & & \multicolumn{2}{|c|}{$\begin{array}{l}\text { 5. Project Title/No. Work Order No. } \\
\text { Spent Nuclear Fuel Project Regulatory } \\
\text { Integration \& Public Involvement }\end{array}$} & \multicolumn{2}{|c|}{$\begin{array}{l}\text { 6. Bldg. /Sys./Fac. No. } \\
\text { N/A }\end{array}$} & $\begin{array}{c}\text { 7. Approval Designator } \\
\qquad, S, Q, D\end{array}$ \\
\hline & & \multicolumn{2}{|c|}{$\begin{array}{l}\text { 8. Cocument Numbers Changed by this ECN } \\
\text { (includes sheet no. and rev.) } \\
\text { WHC-SD-SNF-PLN-012, Rev. } 1\end{array}$} & \multicolumn{2}{|c|}{ 9. Related ECN No(s). } & $\begin{array}{l}\text { 10. Related PO No. } \\
\qquad N / A\end{array}$ \\
\hline \multicolumn{2}{|l|}{ 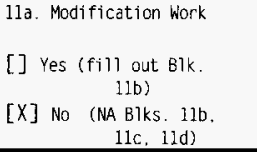 } & $\begin{array}{l}\text { 11b. Work Package } \\
\text { No. } \\
\text { N/A }\end{array}$ & \multicolumn{2}{|c|}{$\begin{array}{l}\text { 11c. Modification Work Complete } \\
\text { N/A } \\
\text { Cog. Engineer Signature \& Date }\end{array}$} & \multicolumn{2}{|c|}{$\begin{array}{l}\text { 11d. Restored to Original Condi- } \\
\text { tion (Temp. or Standby ECN only) } \\
\text { N/A }\end{array}$} \\
\hline
\end{tabular}

12. Description of Charge

Not a baseline document.

This document is being revised in its entirety to address comments on Revision 1.

13a. Justification (mark one)

Criteria Change []

As-Found

[]

Design Improvenent

[]

Environimental

[]

Facility Deactivation

Const. Error/Omission

[] Design Error/Omission

13b. Justification Details

The document is being revised based on comments received on Revision 1 of the plan by the Department of Energy and the Independent Review Panel in April. May, and June, 1996.

14. Distribution (include name. MSIN, and no, of copies)

Distribution Coversheet Attached.

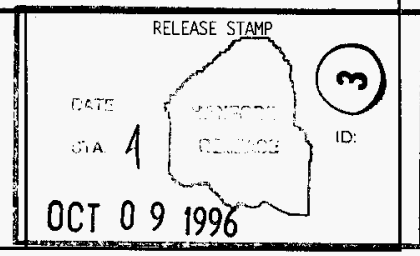

A-7900-013-2 (11/94) GEF095 


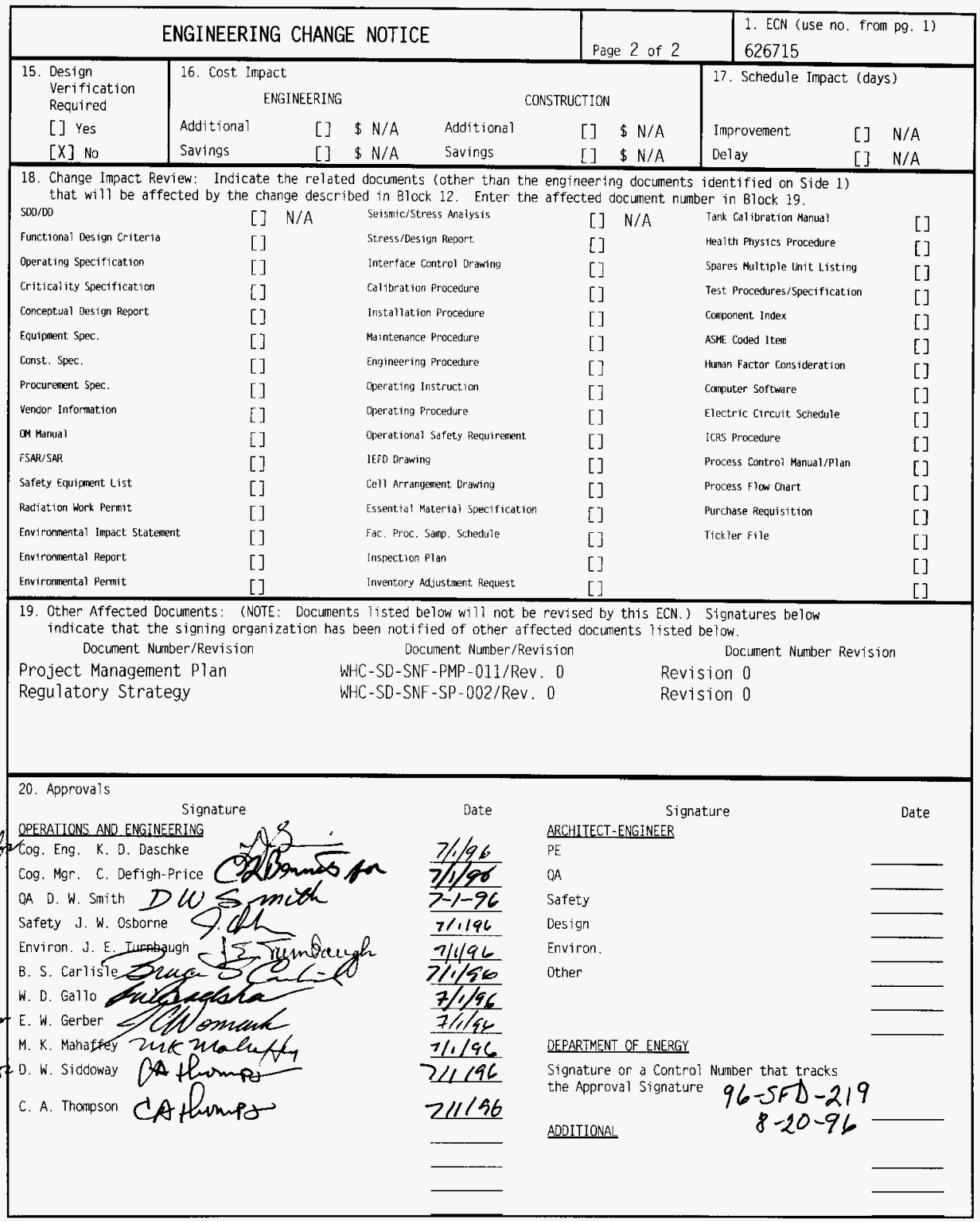




\section{Spent Nuclear Fuel Project Integrated Safety Management Plan}

\section{Kent D. Daschke}

Westinghouse Hanford Company, Richland, WA 99352

U.S. Department of Energy Contract DE-AC06-87RL10930

EDT/ECN: 626715 kns \%//4

Org Code: 5V400

B\&R Code: EW3135040
UC: 510

Charge Code: F93DL1

Total Pages: $\angle 76$

Key Words: Safety, Safety Management

Abstract: This document is being revised in its entirety and the document title is being revised to "Spent Nuclear Fuel Project Integrated Safety Management Plan.

TRADEMARK DISCLAIMER. Reference herein to any specific commercial product, process, or service by trade name. trademark, manufacturer, or otherwise, does not necessarily constitute or imply its endorsement, recommendation, or favoring by the United States Government or any agency thereof or its contractors or subcontractors.

Printed in the United States of America. To obtain copies of this document contact: WHC/BCS Document Control Services, P.0. Box 1970. Mailstop H6-08. Richland WA 99352. Phone (509) 372-2420; Fax (509) 376-4989
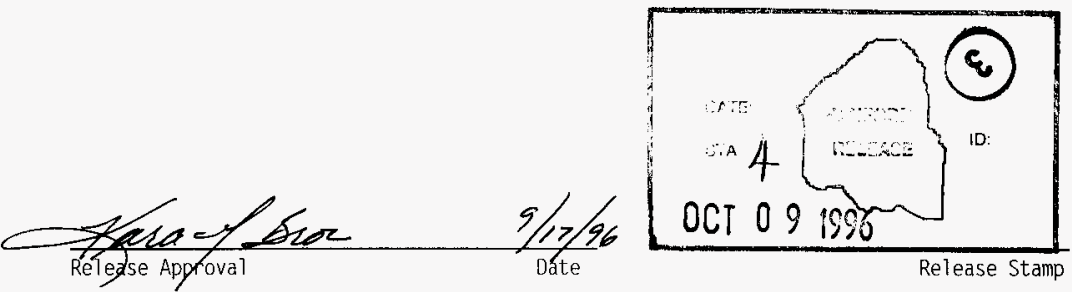

\section{Approved for Public Release}


RECORD OF REVISION

(2) ritle

Spent Nuclear Fuel Project

Integrated Safety Management Plan (ECN 626715)

CHANGE CONTROL RECORD

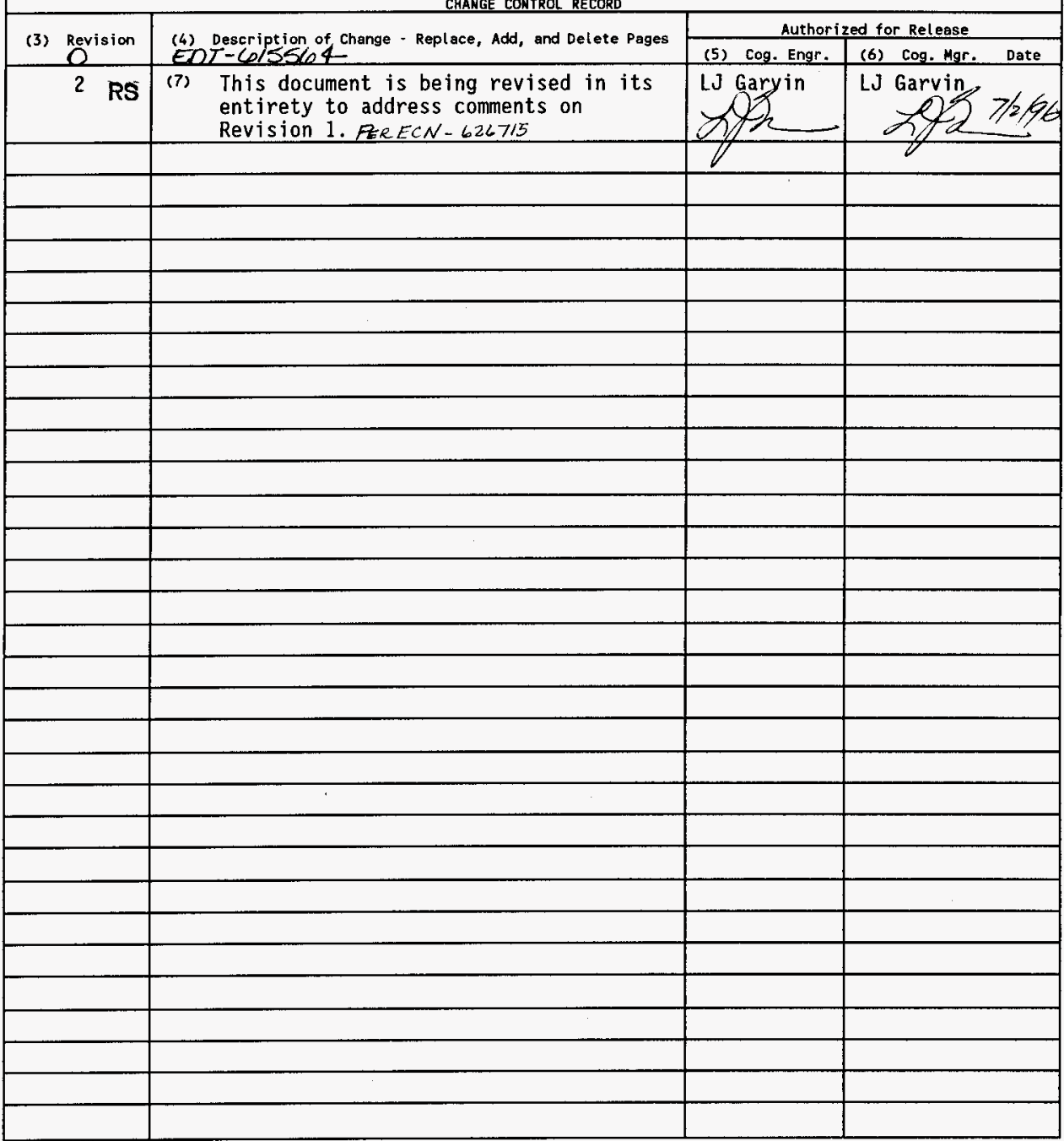




\section{SPENT NUCLEAR FUEL PROJECT INTEGRATED SAFETY MANAGEMENT PLAN}

Spent Nuclear Fuel Project

June 1996

Prepared for the U.S. Department of Energy

Office of Environmental Restoration and Waste Management

Westinghouse Hanford Company

P. O. Box 1970

Richland, Washington 99352 


\section{CONTENTS}

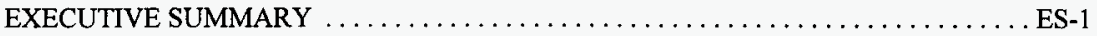

1.0 BACKGROUND AND INTRODUCTION $\ldots \ldots \ldots \ldots \ldots \ldots \ldots \ldots \ldots \ldots \ldots \ldots \ldots \ldots$

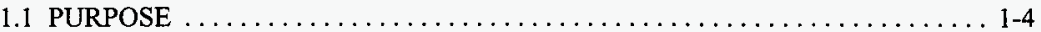

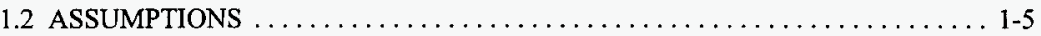

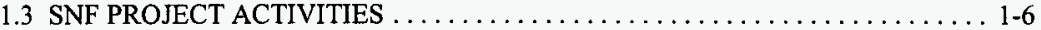

1.4 SNF PROJECT SAFETY MANAGEMENT ROLES AND RESPONSIBILITIES 1-7

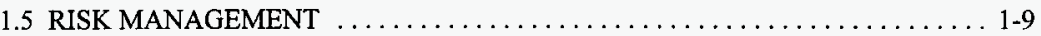

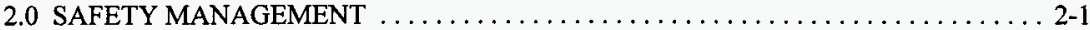

2.1 SNF PROJECT SAFETY MANAGEMENT APPROACH $\ldots \ldots \ldots \ldots \ldots \ldots .2-1$

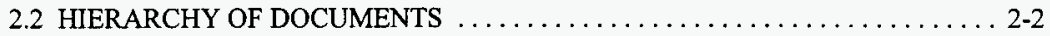

$2.3 \mathrm{~K}$ BASIN SPENT NUCLEAR FUEL PROJECT REGULATORY POLICY $\ldots \ldots .2-3$

2.4 NRC NUCLEAR SAFETY EQUIVALENCY $\ldots \ldots \ldots \ldots \ldots \ldots \ldots \ldots \ldots \ldots \ldots \ldots$

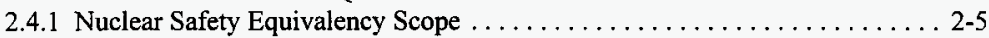

2.4.2 Nuclear Safety Equivalency for New SNF Project Facility SARs $\ldots \ldots \ldots 2-6$

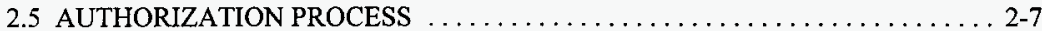

2.5.1 Public Involvement $\ldots \ldots \ldots \ldots \ldots \ldots \ldots \ldots \ldots \ldots \ldots \ldots \ldots \ldots \ldots \ldots \ldots \ldots \ldots, 2-7$

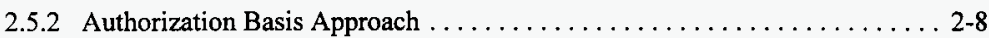

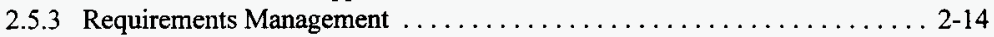

2.5.4 Safety Analysis Process and Documentation $\ldots \ldots \ldots \ldots \ldots \ldots \ldots \ldots .2-21$

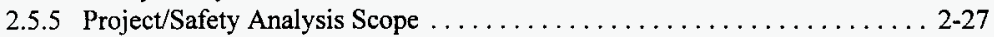

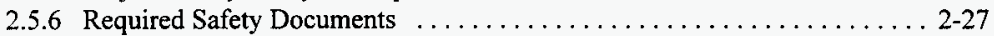

2.5.7 K Basins SAR/OSR Preparation, Review, and Approval .......... 2-27

2.5.8 SAR/TSR Preparation, Review, and Approval for New Facilities . . . . . . 2 2-33

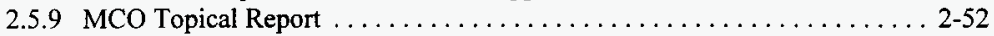

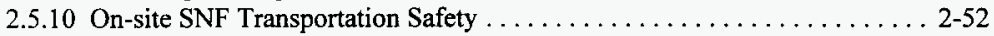

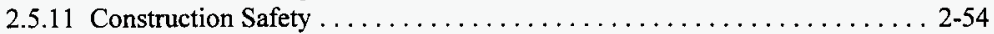

2.5.12 Operational Readiness Review/Declaration of Readiness . . . . . . . . 2 2-55

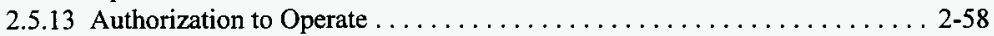

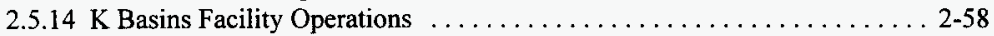

2.5 .15 Other Spent Nuclear Fuel $\ldots \ldots \ldots \ldots \ldots \ldots \ldots \ldots \ldots \ldots \ldots \ldots .2-58$

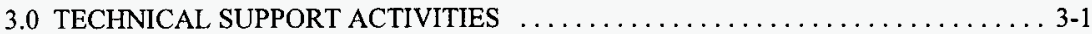

3.1 OVERVIEW OF MAJOR TECHNICAL SUPPORT PROGRAMS $\ldots \ldots \ldots \ldots$ 3-1

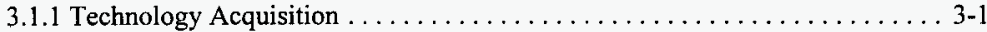

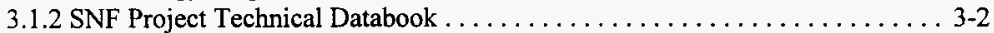

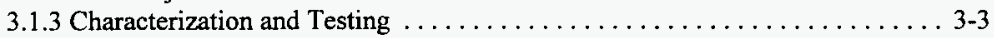

3.2 PROCESS CHARACTERISTICS AFFECTING SAFETY ANALYSIS $\ldots \ldots \ldots$ 3-3

3.3 INTEGRATION OF TECHNICAL SUPPORT FOR SUBPROJECTS $\ldots \ldots \ldots \ldots 3-4$ 


\section{CONTENTS cont.}

\subsection{TECHNICAL SUPPORT ACTIVITIES TO SUPPORT DESIGN AND SAFETY} ANALYSIS (SUMMARY LEVEL) $\ldots \ldots \ldots \ldots \ldots \ldots \ldots \ldots \ldots \ldots \ldots \ldots$

3.4.1 Characterization and Technology Acquisition Program Support of Safety Analysis .................................... 3-7

3.4.2 Integrated Testing Support of Safety Analysis . . . . . . . . . . . . .

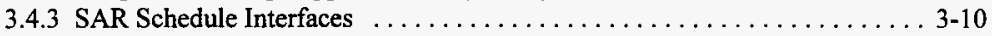

4.0 SNF PROJECT ENVIRONMENTAL DOCUMENTATION $\ldots \ldots \ldots \ldots \ldots \ldots .4$.

4.1 NEPA Documentation $\ldots \ldots \ldots \ldots \ldots \ldots \ldots \ldots \ldots \ldots \ldots \ldots \ldots \ldots \ldots \ldots \ldots \ldots, 1$

4.2 Environmental Regulatory Requirements and Permitting .............. 4-2

4.3 Identification of Required Spent Nuclear Fuel Project Environmental Permits ... . 4-3

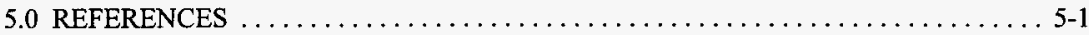

APPENDIX A - SPENT NUCLEAR FUEL PROJECT SAFETY ANALYSIS

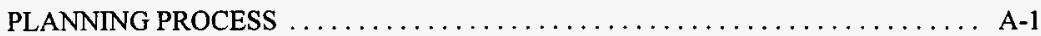

APPENDIX B - SUMMARY OF TECHNOLOGY ACQUISITION PROGRAM AND

CHARACTERIZATION PROGRAM TECHNICAL REPORTS ............. B-1 


\section{LIST OF TABLES}

2-1. K Basins Modifications - SNF Project Authorization Approach $\ldots \ldots \ldots \ldots \ldots \ldots$ 2-9

2-2. New Facility, MCO, and Transportation and Packaging Authorization Approach . . . 2 2-10

2-3. MCO Topical Report Content ............................. 2-26

2-4. SNF Project K Basins Modifications -

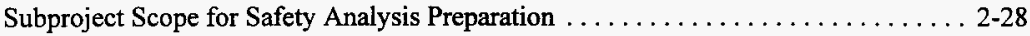

2-5. SNF Project New Facility, MCO, and Transportation System -

Subproject Scope for Safety Analysis Preparation . . . . . . . . . . . . . . . 2-29

2-6. Key Models and Technical Input for Accident Analysis ................ 2-31

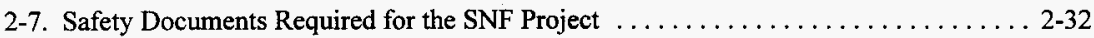

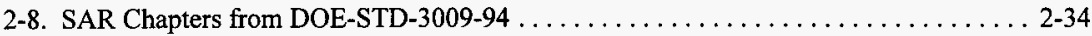

2-9. SNF Program New Facility Safety Documentation Task Responsibility Matrix . . . . . 2-43

2-10. SNF Program New Facility Safety Documentation Approval Matrix $\ldots . . \ldots \ldots . .24$

2-11. Canister Storage Building Phased Safety Analysis Report Approach ........... 2-46

2-12. Cold Vacuum Drying Phased Safety Analysis Report Approach $\ldots \ldots \ldots \ldots \ldots \ldots$ 2-49

2-13. Hot Conditioning Annex Phased Safety Analysis Addendum Approach $\ldots \ldots \ldots \ldots$ 2-51

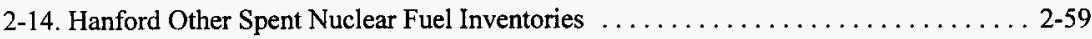

3-1. Process Characteristics and Potential Hazards that Drive Safety Analysis . . . . . . 3-5

3-2. Process Control Strategy for Retained Water Inventory Issue $\ldots \ldots \ldots \ldots \ldots \ldots . . \ldots \ldots$

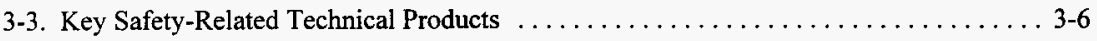

3-4. Integration of Technical Support Activities with CSB-Phased SAR . . . . . . . . 3-11

3-5. Integration of Technical Support Activities with CVD- and HCS-Phased SARs and MCO Topical ....................................... 3-14

4-1. Matrix of Environmental Documents Required for SNF Project Subprojects . . . . . . 4-4 


\section{LIST OF FIGURES}

2-1. Review and Approval of SNF Project New Facility Requirements Basis for NRC

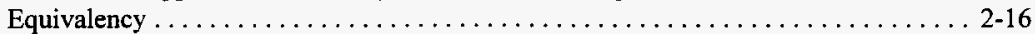

2-2. Typical Safety Analysis Process for New Facilities $\ldots \ldots \ldots \ldots \ldots \ldots \ldots \ldots . \ldots \ldots .2-22$

2-3. Construction Authorization - Phased SAR Chapter 3 Logic Model ........... 2-37

2-4. Phased SAR Review and Approval Process for SNF Project New Facilities . . . . . 2-38

2-5. SAR Review and Approval Process for SNF Project New Facilities $\ldots \ldots \ldots \ldots \ldots .2-40$

2-6. Diagrammatic Schedule of CSB Phased SAR Activities............... 2-45

2-7. Diagrammatic Schedule of CVD Phased SAR Activities. $\ldots \ldots \ldots \ldots \ldots \ldots \ldots . \ldots \ldots 2-48$

2-8. Diagrammatic Schedule of HCS Phased SAR Activities $\ldots \ldots \ldots \ldots \ldots \ldots \ldots \ldots \ldots \ldots$

2-9. Diagrammatic Schedule of MCO Topical Report $\ldots \ldots \ldots \ldots \ldots \ldots \ldots \ldots \ldots \ldots \ldots \ldots \ldots \ldots$ 


\section{ABBREVIATIONS AND ACRONYMS}

\begin{tabular}{|c|c|}
\hline ANL-W & Argonne National Laboratory - West \\
\hline $\mathrm{CCCs}$ & Core Component Containers \\
\hline CDR & Conceptual Design Report \\
\hline CFR & Code of Federal Regulations \\
\hline $\mathrm{CM}$ & Configuration Management \\
\hline $\mathrm{C}$ of $\mathrm{C}$ & Certificate of Compliance \\
\hline CSB & Canister Storage Building \\
\hline CSER & Criticality Safety Evaluation Report \\
\hline CVD & Cold Vacuum Drying \\
\hline $\mathrm{D} \& \mathrm{D}$ & Decontamination and Decommissioning \\
\hline DNFSB & Defense Nuclear Facilities Safety Board \\
\hline DOE & U.S. Department of Energy \\
\hline $\mathrm{DOH}$ & Washington State Department of Health \\
\hline DOT & U.S. Department of Transportation \\
\hline DRS & Debris Removal System \\
\hline $\mathrm{EH}$ & Environmental Health (DOE) \\
\hline $\mathrm{EH}-\mathrm{O}$ & Environmental Safety and Health - Independent Oversight (DOE-HQ) \\
\hline $\mathrm{EH}-\mathrm{T}$ & Environmental Safety and Health - Technical Support (DOE-HQ) \\
\hline EIS & Environmental Impact Statement \\
\hline EM & Environmental Restoration and Waste Management (DOE) \\
\hline EPA & U.S. Environmental Protection Agency \\
\hline $\mathrm{ES} \& \mathrm{H}$ & Environment, Safety and Health \\
\hline FDC & Functional Design Criteria \\
\hline FEIS & Final Environmental Impact Statement \\
\hline FFTF & Fast Flux Test Facility \\
\hline FHA & Fire Hazards Analysis \\
\hline FRD & Functions and Requirements Documents \\
\hline FRS & Fuel Retrieval System \\
\hline $\mathrm{HCS}$ & Hot Conditioning System \\
\hline HQ & Headquarters (DOE) \\
\hline IPS & Integrated Process Strategy \\
\hline IRP & Independent Review Panel \\
\hline ISA & Interim Storage Area \\
\hline ISC & Interim Storage Cask \\
\hline ISMP & Integrated Safety Management Plan \\
\hline IWTS & Integrated Water Treatment System upgrade \\
\hline KE & $\mathrm{K}$ East Basin \\
\hline KW & K West Basin \\
\hline $\mathrm{KR}$ & K Basins Review \\
\hline LLBG & Low-level Burial Grounds \\
\hline LWR & Light Water Reactor \\
\hline $\mathrm{MCO}$ & Multi-Canister Overpack \\
\hline MOU & Memorandum of Understanding \\
\hline MPC & Multi-purpose Canister \\
\hline
\end{tabular}




\section{ABBREVIATIONS AND ACRONYMS cont.}

\begin{tabular}{|c|c|}
\hline NEPA & National Environmental Policy Act \\
\hline NESHAPS & National Emission Standards for Hazardous Air Pollutants \\
\hline NOC & Notice of Construction \\
\hline NRC & U.S. Nuclear Regulatory Commission \\
\hline NRF TRIGAB & $\begin{array}{l}\text { Neutron Radiography Facility Test Reactor and Isotope Production } \\
\text { General Atomics }\end{array}$ \\
\hline OCRWM & Office of Civilian Radioactive Waste Management \\
\hline ORR & Operational Readiness Review \\
\hline OSR & Operational Safety Requirements \\
\hline PDC & Packaging Design Criteria \\
\hline PFP & Plutonium Finishing Plant \\
\hline PHA & Preliminary Hazards Assessment \\
\hline PMP & Project Management Plan \\
\hline PNNL & Pacific Northwest National Laboratory \\
\hline PSAR & Preliminary Safety Analysis Report \\
\hline PSE & Preliminary Safety Evaluation \\
\hline PWR & Pressurized Water Reactor \\
\hline QA & Quality Assurance \\
\hline RI\&PI & Regulatory Integration and Public Involvement (SNF Project) \\
\hline RL & Richland Operations Office (DOE) \\
\hline ROD & Record of Decision \\
\hline RRT & Regulatory Requirements Team \\
\hline S/RID & Standards/Requirements Identification Document \\
\hline SAR & Safety Analysis Report \\
\hline SARP & Safety Analysis Report for Packaging \\
\hline SEAC & Safety and Environmental Advisory Council \\
\hline SEMP & Systems Engineering Management Plan \\
\hline SEPA & State Environmental Policy Act \\
\hline SER & Safety Evaluation Report \\
\hline SFD & Spent Nuclear Fuel Project Division (DOE) \\
\hline SNF & Spent Nuclear Fuel \\
\hline SNF Project & Spent Nuclear Fuel Project \\
\hline SNFPO & Spent Nuclear Fuel Project Office (DOE) \\
\hline SRS & Sludge Removal System \\
\hline TAP & Technology Acquisition Plan \\
\hline TSR & Technical Safety Requirements \\
\hline TWRS & Tank Waste Remediation System \\
\hline USQ & Unreviewed Safety Question \\
\hline WAC & Washington Administrative Code \\
\hline WHC & Westinghouse Hanford Company \\
\hline
\end{tabular}




\section{EXECUTIVE SUMMARY}

The Spent Nuclear Fuel Project (SNF Project) is committed to the implementation of a comprehensive safety management plan that ensures protection of the public, workers, and the environment. The SNF Project approach to safety management is described in this Integrated Safety Management Plan (ISMP). The Project's safety management approach provides for a defense-in-depth safety culture in the context of the Defense Nuclear Facilities Safety Board's (DNFSB) Recommendation 95-2, Safery Management (Conway 1995), and complies with the policy defined by the U.S. Department of Energy's (DOE) K Basins Spent Nuclear Fuel Project Regulatory Policy (DOE 1995). In addition, as the ISMP further evolves, it will be updated to incorporate all elements of the DOE's Implementation Plan for DNFSB 95-2 (DOE 1996a). This update will systematically address the seven safety management Guiding Principles and the safety management functions of the DOE Implementation Plan.

The ISMP implements the SNF Project Regulatory Strategy (WHC 1995a) and defines the safety processes, requirements, and responsibilities to be applied to the SNF Project. The ISMP applies to all activities and facilities in the SNF Project during the acquisition and operation phases, including: K Basins maintenance and operations; fuel retrieval, cleaning, and repackaging; sludge and debris removal from the $\mathrm{K}$ Basins; packaging and transportation of the fuel; the cold vacuum drying facility and operations; the hot conditioning facility and operations; the Canister Storage Building (CSB) facility and operations; and for management of other Hanford spent nuclear fuel (SNF).

The ISMP describes the necessary programs and processes required to maintain the existing $\mathrm{K}$ Basins authorization basis and to develop the authorization basis for new SNF processes and facilities that ensure compliance with applicable environmental, safety, and health requirements. The ISMP describes the following:

- Development and maintenance of the authorization basis for the SNF Project facilities, including the Safety Analysis Reports (SARs), Technical Safety Requirements (TSRs) and Operational Safety Requirements (OSRs), Standards and Requirements Identification Documents (S/RIDs), and environmental documentation.

- Implementation of a phased SAR preparation and approval process to expedite authorization of construction of SNF Project facilities.

- Identification of specific safety analyses required to establish the authorization basis and specific SNF Project activities that support those analyses. This includes results of the fuel characterization program, technical analyses, model development, and testing required to verify enabling assumptions and close technical issues associated with the safety analyses. 
- Independent review and approval of the authorization basis, including Operational Readiness Reviews (ORRs), as required.

The ISMP will be updated as required to reflect changes in the SNF Project Regulatory Policy (DOE 1995) or the SNF Project Regulatory Strategy (WHC 1995a), and to reflect the results of more detailed project planning and scheduling. 


\section{SPENT NUCLEAR FUEL PROJECT INTEGRATED SAFETY MANAGEMENT PLAN (ISMP)}

\subsection{BACKGROUND AND INTRODUCTION}

The Hanford $\mathrm{K}$ Basins ( $\mathrm{K}$ East and $\mathrm{K}$ West Basins) are currently being maintained and operated to store approximately 2100 metric tons of N Reactor spent nuclear fuel. The Spent Nuclear Fuel Project (SNF Project) was formed in 1994 to address the urgent need to move the deteriorated spent nuclear fuel (SNF) from the K Basins to safe interim storage. In October 1994, the SNF Project recommended a Path Forward (WHC 1994a) to define the major process steps and facilities needed to achieve safe interim storage. Along with approval of the Path Forward in February 1995, DOE assigned an accelerated schedule goal to start fuel removal from the K Basins by December 1997 (one year earlier than the Path Forward recommendation), to complete fuel conditioning for dry storage as soon as feasible, and to implement those accelerations within current budget projections. The Integrated Process Strategy (IPS) (WHC 1995b) was developed to establish the technical framework to construct facilities and implement processes compatible with these goals. Major innovations, including repackaging the fuel into storage baskets to reduce needed storage space and containers for the fuel, removal of fuel corrosion products and other sludges, and application of a two-step fuel drying and conditioning process were developed to enable the Project to resolve technical issues and meet these goals.

Current plans are to remove fuel assemblies from the existing canisters, clean the fuel, and place it into specially designed baskets. The baskets will be placed into approximately 400 multi-canister overpacks (MCOs) containing five baskets each. Prior to shipment, the MCOs will be dewatered and vacuum dried at the Cold Vacuum Drying (CVD) facility. MCOs will be sealed and shipped to the newly constructed Canister Storage Building (CSB). At the CSB, the MCOs will be staged until the Hot Conditioning System (HCS), located in an annex to the CSB, is available to complete the processing required for dry interim storage. The MCOs will be held in interim storage at the CSB until final disposition can be achieved (in approximately 40 years). Interim storage of other, non-K Basin SNF will also occur within the CSB or in a 200 Area Interim Storage Area (ISA) adjacent to the CSB.

In order to accomplish the removal of the K Basins' spent fuel, sludge, and debris, several new systems and modifications to the $\mathrm{K}$ Basins will be necessary. The new systems include the Fuel Retrieval System (FRS), Sludge Removal System (SRS) and Debris Removal System (DRS). Modifications will also be made to the $\mathrm{K}$ Basins to allow installation of these systems, to provide related infrastructure support (K Basins Modifications), and to install an Integrated Water Treatment System (IWTS). The IWTS upgrade will handle the increased need for treated water to support the new systems and maintain basin water quality during in-basin activities. 
The SNF Project mission is to provide safe, economic, and environmentally sound management of Hanford's SNF. This includes transfer of the K Basins SNF into dry interim storage, and to oversee and direct activities associated with other Hanford SNF. When safe interim storage of the K Basins fuel has been attained, all Hanford SNF, facilities, equipment, documentation, and personnel will be assigned to other Hanford projects for management and for facility decontamination and decommissioning (D\&D).

The Defense Nuclear Facilities Safety Board (DNFSB) Recommendation 95-2 (Safety Management) recommends a safety management process be applied to the design, construction, and operation of defense nuclear facilities. The SNF Project has applied DNFSB 95-2 principles to develop this Integrated Safety Management Plan (ISMP). This plan describes the process for preparing the safety authorization basis documents for the design, construction, and operation of the SNF Project new facilities, the K Basins modifications, and for transfer and storage of other Hanford SNF. The ISMP provides the approach for developing and maintaining the SNF Project Safety Analysis Reports (SARs) and Operational Safety Requirements (OSRs)/Technical Safety Requirements (TSRs).

The ISMP is a living document and will remain in effect until all SNF Project facilities are transitioned for $D \& D$. In keeping with this approach, the ISMP will be updated to reflect the recently developed DOE Implementation Plan for DNFSB 95-2 (DOE 1996a). The ISMP will address the seven safety management Guiding Principles and the safety management functions as defined in the DOE Implementation Plan. These principles and functions, which are addressed to a significant degree in this version of the ISMP, are as follows:

\section{Guiding Principles}

- Line management responsibility for safety

- Clear roles and responsibilities

- Competence commensurate with responsibilities

- Balanced priorities

- Identification of safety standards and requirements

- Operations authorization

- Hazard control tailored to work.

\section{Functions}

- Define scope of work

- Analyze hazards

- Develop/implement controls

- Perform work 
- Feedback/improvement.

The DNFSB has issued recommendations (Conway 1990, 1992, 1995) on the application of appropriate standards and requirements to govern operating practices by contractors at the DOE defense nuclear facilities. The recommendations focus on the environmental, safety, and health (ES\&H) aspects of DOE's facility operations. The DOE has implemented a requirements development program in conformance with DNFSB recommendations, which include: identifying specific standards and requirements that apply, reviewing the adequacy of the standards, and determining the extent to which the standards have been implemented to ensure the protection of public health and safety at these facilities. The standards and requirements are collected in facility-specific documents known as Standards/Requirements Identification Documents (S/RIDs).

The specific standards and requirements that apply to the Hanford site are being identified by the implementation of an S/RIDs program (Wagoner 1994a and 1994b). Based on DOE direction for implementing DNFSB Recommendation 90-2, an operating facility at Hanford must have an approved S/RID in place by 1996. The S/RID for the K Basins was approved by the DOE on November 27, 1995 (Wagoner 1995). The new facilities at the Hanford site must develop S/RIDs as the facilities transition from design, construction, and start-up into the operations phase. The SNF Project will use the systems engineering approach to identify the functions and requirements for the new facilities. The S/RIDs for new facilities, and updates to the $\mathrm{K}$ Basins S/RIDs, will be derived from the systems engineering database as the projects transition from construction to operations, and will be verified for consistency with approved baseline requirements documents.

Additionally, the DOE has also applied the systems engineering methodology to the Hanford site in response to DNFSB Recommendations 92-4 and 94-1 (Conway 1992 and 1994). Systems Engineering is being implemented at Hanford based on this guidance and DOE Order 4700.1, Project Management System. Systems engineering is a formal discipline that systematically defines and controls the mission, functions and requirements, and the design baselines for programs and projects. DOE guidance for the systems engineering process at Hanford is provided by RLPD 430.1, Hanford Site Systems Engineering Policy (DOE 1996b) and RLID 430.1, Systems Engineering Criteria Document and Implementing Directive (DOE 1996c). The systems engineering process encompasses all requirements for a program and/or project, including laws, DOE Orders, U.S. Nuclear Regulatory Commission (NRC) and other regulations, and national standards for all phases of the project (e.g., design, construction, and operations).

The SNF Project has implemented the Hanford systems engineering process. The Spent Nuclear Fuel Project System Engineering Management Plan (SEMP) (WHC 1995c) establishes the systems engineering requirements for the project, and defines the process for development and control of the SNF Project technical baseline (WHC 1996a). 


\subsection{PURPOSE}

The ISMP describes the safety management process to achieve a defense-in-depth safety culture for design, construction, and operation of SNF Project facilities to assure protection of the public, workers, and the environment. The ISMP establishes the project plan for developing and maintaining an authorization basis for all aspects of the SNF Project. The ISMP reflects the current planning basis for the SNF Project. The safety programs and processes described in this document are consistent and in compliance with the policy for nuclear safety provided in the K Basins Spent Nuclear Fuel Project - Regulatory Policy (DOE 1995; hereafter referred to as the Regulatory Policy).

The ISMP addresses the following aspects of SNF safety management:

- Technical issues and risk management, and development of technical data (technical data development, characterization, and test data) to support safety analysis preparation.

- Preparation, review, and approval of safety and environmental permitting documentation, including definition of the approach for submittal of new facility SAR chapters in phases to expedite construction and operation of the SNF Project facilities.

- Integrating safety analysis and environmental permitting activities with design, construction, startup, and operation activities.

- Preparation, review, and approval of safety documentation associated with the on-site transportation and storage of other Hanford SNF.

- Management roles and responsibilities related to safety management to ensure the ISMP is implemented during design, construction, and operation of the SNF Project facilities.

The ISMP covers all SNF Project activities, including:

- K Basins operations.

- Design and construction of $\mathrm{K}$ Basins modifications, including the cask and transportation system interfaces, FRS, SRS, DRS, and IWTS.

- Design, construction, and operation of the CVD facility.

- Design, construction, and operation of the CSB.

- Design, construction, and operation of the HCS facility. 
- Design and fabrication of the cask and transportation system.

- Transportation of the spent fuel, sludge, and debris.

- Disposition of the sludge.

The ISMP does not address specific safety-related activities associated with D\&D work following transfer of the SNF facilities to other Hanford projects. However, the individual facility SARs will include an evaluation of D\&D to conform to the requirements of DOE Order 5480.23.

Section 4.0 of the ISMP describes the environmental documentation portion of the SNF Project authorization basis, which fulfills the SNF Project Management Plan requirement for a permitting plan (WHC 1995d).

\subsection{ASSUMPTIONS}

Key assumptions associated with the regulatory approach are listed below:

- Extended storage of fuel in the $\mathrm{K}$ Basins is unacceptable. The need for expedited removal of the fuel and sludge from the $\mathrm{K}$ Basins to a safer location away from the Columbia River justifies the accelerated schedules for safety and environmental review and the acceptance of programmatic risk.

- The K Basins SNF and adhered sludge that is not removed by the cleaning process will be managed as SNF in accordance with the Federal Atomic Energy Act and other applicable rules. This material will not be managed as waste under the federal Resource Conservation and Recovery Act regulations or the Washington Administrative Code (WAC). Sludge is considered SNF until it has been removed from the $\mathrm{K}$ Basins. Sludge that is removed from the $\mathrm{K}$ Basins by a sludge retrieval process will be handled as mixed waste after removal from the Basins for disposition through the Tank Waste Remediation System (TWRS).

- DOE will provide independent nuclear safety oversight and enforcement for the SNF Project. Independent review by the NRC staff of the SNF Project activities and facilities will not be required as part of the DOE authorization process.

- The SNF Project assumes the SNF will be moved for final disposition prior to exceeding the design life of the CSB. Final disposition of the SNF is unclear at this time; however, the SNF Project is considering the existing and draft SNF requirements for the geological repository. 
- Due to the urgent nature of the situation at the K Basins, the SNF Project regulatory strategy will not be subject to retroactive changes.

- The DOE Regulatory Policy on NRC nuclear safety equivalency will be applied to the SNF new facilities and activities associated with fuel removal from the $\mathrm{K}$ Basins, which have influence on the fuel acceptance criteria.

- The SNF Project can determine the final form or condition of the fuel based on the need for stable interim storage over a period of decades, without needing to achieve a waste form acceptable for disposal over periods of thousands of years.

\subsection{SNF PROJECT ACTIVITIES}

The life cycle of the SNF facilities and project activities will include the following phases:

- Operation ${ }^{1}$ of the $\mathrm{K}$ Basins for storage of the SNF.

- Design and construction of the K Basins systems necessary to support fuel, debris, and sludge removal activities.

- Design and fabrication of the MCOs and transportation system.

- Development, construction, and startup of the CVD facility.

- Fuel removal, debris removal, and sludge retrieval, staging, and removal operations.

- Transfer of K Basins sludge to TWRS.

- CVD facility operations.

- Transportation of the MCOs to the CSB.

- Transition of the K Basins for D\&D.

- Transition of the CVD facility for D\&D.

- Development, construction, and startup of the CSB.

' Operations includes all aspects of SNF facility operations; such as, preparation and control of procedures, personnel training, equipment maintenance, radiation protection (ALARA) programs, waste management, and records management. 
- CSB operations associated with staging and storage of K Basins SNF.

- Development, construction, and startup of the HCS facility.

- HCS operations.

- Transition of the HCS facility for D\&D.

- Interim storage of other Hanford SNF.

- Transition of the CSB to other Hanford projects for operations and other uses.

This ISMP document will be revised to reflect the changes in scope of the SNF Project.

\subsection{SNF PROJECT SAFETY MANAGEMENT ROLES AND RESPONSIBILITIES}

The Spent Nuclear Fuel Project, Project Management Plan (PMP) (WHC 1995d), SNF Project SEMP (WHC 1995c), Quality Assurance Program Plan (WHC 1996b), and Contractor implementing procedures provide the SNF Project charter and identify the organizational structure, functional responsibilities, levels of authority, and lines of communication for activities affecting safety for the SNF Projects. These responsibilities, as related to safety management, are delegated to various SNF Project organizations as described below:

- SNF Project Director - This individual is responsible for assuring a defense-in-depth safety culture is established for the SNF Project, assuring that subproject managers comply with the requirements of the ISMP when carrying out their responsibilities, and for assuring that SNF Project activities are conducted in a safe manner.

- SNF Subproject Managers - These individuals are responsible for assuring that design, construction, and safety management activities associated with their subproject scopes meet the intent and requirements of the ISMP. They are also responsible for assuring that systems engineering is properly employed for all SNF Project activities to define the necessary functions and requirements (Functions and Requirements Document [FRD] or Functional Design Criteria [FDC]).

- SNF Engineering - This organization is responsible for managing the systems engineering process. The organization is also responsible for completing the design support activities, and supporting the development and/or maintenance of the authorization bases such that the authorization basis demonstrates that SNF Project facilities and activities protect the health and safety of the workers, the public, and the environment per the ISMP. 
- SNF Subproject Design Authorities - These individuals are part of SNF Engineering and are responsible for assuring that the functions and requirements (FRD or FDC documents) and design process for the subproject provides reasonable assurance that the facilities and system provided can be designed, constructed, authorized, and operated in a safe manner. The subproject design authorities also perform an evaluation of the design changes that occur during construction for compliance with or impact to the project technical baseline and safety basis. The Design Authorities provide input to and perform reviews and approvals of the Project safety analyses, SARs, MCO Topical Report, and Criticality Safety Evaluation Reports (CSERs).

- K Basins Standards and Requirements - This organization is responsible for identifying and ensuring compliance with the nuclear and environmental safety aspects of the ES\&H requirements that are applicable to the $\mathrm{K}$ Basins and related modifications and responsible for updating and maintaining the $\mathrm{K}$ Basins facility authorization basis per the ISMP.

- Packaging and Transportation - This organization is responsible for identifying and ensuring compliance with the regulatory requirements that are applicable to transportation of SNF and sludge, and developing the Safety Analysis Report for Packaging (SARP) for on-site transportation activities per the ISMP.

- SNF Operations - These organizations are responsible for managing operation of the SNF Project facilities in a safe manner in compliance with the authorization basis per the ISMP. Operations integrates the safety basis into procedures, personnel training, and system configuration control. SNF Operations includes:

- Fuel Handling Operations - This organization is responsible for fuel retrieval operations in the K Basins, transfer of the fuel to the CVD facility, CVD facility operations, transfer of the fuel to the CSB, CSB operations, transfer of the fuel to the HCS facility, and HCS facility operations, in compliance with the authorization basis.

- K Basins Operations - This organization is responsible for all other K Basins operations, including sludge removal, debris removal, etc., in compliance with the authorization basis.

- Regulatory Integration and Public Involvement (RI\&PI) - This organization is responsible for the development of the authorization basis for new facilities (CVD, CSB, HCS) and the integration of the authorization basis of these facilities with the corresponding transportation and packaging activities. Additionally, RI\&PI is responsible for ensuring compliance with the regulatory requirements that are applicable to the new SNF Project facilities during design and construction. Other 
regulatory functions, such as environmental compliance and public involvement activities, are also the responsibility of the RI\&PI organization.

\subsection{RISK MANAGEMENT}

The SNF Project has undertaken an aggressive schedule with the goal of early fuel removal from the $\mathrm{K}$ Basins in order to reduce public risk. Disciplined implementation is required to assure the accelerated schedule does not result in undue safety, environmental, technical or financial risk. The SNF Project's approach to management of such risks includes an issues management program for dispositioning major technical issues, and disciplined configuration management practices to assure identification of technical uncertainties in the SNF Project SARs.

The design strategy is based on sound, well-documented technical analyses and reviews, with decisions based on a strong technical foundation and standard design practices. When technical data is limited, technical analyses are based on well-documented, conservative assumptions. This approach reduces the risk inherent in proceeding with limited data. Examples include implementation of the general defense-in-depth principles with strategies such as selection of multiple inherent-passive boundaries when achievable, selection of primary and secondary boundaries as close to the hazard as achievable to provide enhanced personnel protection, provision of backup capabilities for off-normal conditions, and limiting reliance on procedural controls.

A Technical Issue Management Board has been established to identify, track, manage resolution activities, and assure documented resolution of the major project-level issues. This team, chaired by the Deputy Project Manager, consists of senior project managers and a DOE representative. As appropriate for a project during design, issues are referred to the responsible subproject or program to be scheduled and resolved. The proposed resolutions are presented to the Board, and the Board's decisions are documented as changes to the SNF Project technical baseline.

The SARs for new SNF facilities are being transmitted to DOE in phases to accommodate an accelerated review process and ultimate approval. Not all issues will be finally resolved at the time of initial chapter transmission. All issues must be satisfactorily resolved prior to the final DOE approval of the SAR and authorization to operate the facility or activity. Examples that may fall in this category include: (1) characterization of adherent uranium oxide drying characteristics, and (2) benchmarking rate confirmation for irradiated N Reactor fuel and oxygen reactions. These uncertainties will be identified in the appropriate SAR transmittals along with the information currently known, the interim technical justification for use of the assumption in the analysis, the risk associated with the assumption, the impact of an incorrect assumption, the task scope for resolution, and the schedule for resolution. These assumptions will be tracked, and formally verified and documented prior to requesting final DOE operations authorization. 
The Contractor is legally and contractually committed to conduct activities (including design, construction, and operation of facilities) in a safe and environmentally sound manner, and in accordance with the Code of Federal Regulations, DOE Directives, and state regulations. The ISMP provides the plan for meeting these DOE Directives and Rules. The DOE acceptance of this plan, either by review comments or approval, shall not be construed as granting relief from any contractual obligations unless specifically identified as an exception or waiver, and approved by the appropriate DOE authority (i.e., the Contracting Officer). The DOE approval of this ISMP does not constitute approval of the Contractor procedures referenced in this document. The Contractor is accountable to assure the procedures comply with contractual obligations. 


\subsection{SAFETY MANAGEMENT}

This section describes the philosophy and policies that provide reasonable assurance that the SNF Project facilities and activities will be designed, constructed, and operated in a manner that will assure protection of the workers, the public, and the environment. A summary of the requirements to be met is also provided. The Contractor manuals and procedures referenced in this ISMP as implementing DOE Orders and regulations, do not imply DOE approval or acceptance of those manuals and procedures.

\subsection{SNF PROJECT SAFETY MANAGEMENT APPROACH}

The SNF Project has adopted an integrated safety management approach based on defense-in-depth principles that results in the generation of an authorization basis that provides for safe design, construction, and operation. The Project approach is consistent with the safety management principles recommended by the DNFSB (Conway 1995).

Key Safety Management Concepts. The SNF Safety Management approach described in this ISMP is based on four fundamental safety concepts:

- Defense-in-Depth - Designing facilities to provide multiple levels of defense against undue radiation exposure to the workers and the public.

- Minimizing Exposure - Keeping exposure to "as low as reasonably achievable" (ALARA).

- Hazards/Safety Analysis - Defining the hazardous aspects of the activity and features needed to render the probability of inadvertent exposure of workers and the public extremely low.

- Clear Delineation of Safety Responsibility - Defining and exercising responsibility, when using radioactive materials, to assure the safety of workers and the public, and to protect the environment.

Four safety practices and requirement sets embody these concepts:

- Prevention - Requirements pertaining to hazards analysis and the design of systems, structures, and components to prevent undue exposures, whether from normal or abnormal conditions attendant to the work activity or from unusual but credible events. 
- Preservation - Requirements to preserve the designed-in capability of the structures, systems, and components that are important to nuclear safety and for protection of the environment.

- Mitigation - Requirements that reflect possibilities for operational mishaps, man or nature caused, and the emergency response capabilities needed to regain control and mitigate the consequences of dispersed radioactive materials, if released beyond the immediate design barriers.

- Management - Requirements that address the need for detailed procedures and trained and qualified personnel to integrate, manage, and execute the safety functions.

These four concepts and the safety practices or requirements sets were adapted from the DNFSB's safety management recommendations (Conway 1995). They are equally applicable to the handling of hazardous materials for assuring the safety of workers and the public, and for protecting the environment.

\subsection{HIERARCHY OF DOCUMENTS}

The hierarchy of the source documents that define the requirements and implementing plans for the SNF Project is as follows:

- Federal, state, and local law.

- SNF Project requirements identified by contract with the DOE, including the DOE orders and directives made part of the contract requirements.

- DOE's K Basins Spent Nuclear Fuel Project - Regulatory Policy (DOE 1995).

- Spent Nuclear Fuel Project Regulatory Strategy (WHC 1995a).

- Nuclear safety equivalency and additional NRC requirements (WHC 1995e, 1995f, $1995 \mathrm{~g}$, and 1995h).

- OSRs/TSRs, SARs, and S/RIDs.

- Contractor policies and procedures (site-wide). ${ }^{2}$

- SNF Project PMP.

${ }^{2}$ The Contractor manuals and procedures referenced in this ISMP as implementing DOE Orders and regulations, do no imply DOE approval or acceptance of those manuals or procedures. The Contractor is responsible for maintaining manuals and procedures that comply with the DOE requirements. 
- SNF Project ISMP.

- Technical Baseline Description and subproject Functions and Requirements documents.

- Other SNF Project plans and procedures (e.g., Systems Engineering Management Plan, Configuration Management Plan, etc.).

- Subproject plans and procedures (e.g., subproject PMPs).

- Operating/Administrative requirements and procedures (e.g., facility-specific).

\subsection{K BASIN SPENT NUCLEAR FUEL PROJECT REGULATORY POLICY}

The K Basins Spent Nuclear Fuel Project - Regulatory Policy (DOE 1995) establishes DOE's policy that new SNF Project facilities will achieve nuclear safety equivalence to comparable NRC-licensed facilities. The safety management processes established by the ISMP comply with DOE's Regulatory Policy. The Regulatory Policy was developed to achieve three primary objectives:

- To achieve a set of requirements that are technically defensible and cost-effective.

- To achieve in the design and construction of new SNF Project facilities, a level of nuclear safety comparable to that of NRC-licensed commercial facilities.

- To enhance public understanding and confidence in the safety of the new facilities by following an enhanced regulatory strategy.

To facilitate accelerated facility authorization, the DOE established a Regulatory Requirements Team (RRT) comprised of DOE Headquarters (HQ), DOE Richland Operations Office (RL), Contractor, and vendor personnel. The RRT is comprised of individuals thoroughly familiar with the NRC and DOE regulatory requirements.

The RRT was established to help define the requirements to be used by the SNF Project for the new facilities. The RRT assisted with the task of evaluating NRC regulations and guidance to determine NRC requirements to be applied to new SNF Project facilities to achieve nuclear safety equivalency. The RRT members have the responsibility to facilitate review and comments within their organizations on issues that have come before the RRT as a body. The RRT members also have the responsibility to assess the progress of the SNF Project for potential issues and to raise issues to the appropriate level of authority for disposition.

The Regulatory Policy requires an independent review process to ensure that the requirements selected as the basis for the new SNF Project facilities provide an acceptable level 
of worker safety, public health and safety, and protection of the environment. The process is supported by DOE Environmental, Safety and Health (EH) staff and an Independent Review Panel (IRP). The IRP is comprised of nationally recognized technical experts, who provide highlevel external oversight of the requirements selection process. The IRP is an advisory panel that reports directly to the Manager of DOE-RL with duties and responsibilities defined in the Regulatory Policy (DOE 1995).

Federal and state regulations and DOE Directives and Rules comprise the baseline to which new SNF Project facilities are to be designed and constructed. These requirements are supplemented by appropriate and applicable NRC requirements to establish nuclear safety equivalency with comparable NRC-licensed facilities. DOE's Regulatory Policy includes the following major elements:

- Additional regulatory requirements were developed by the Contractor with the help of the RRT. The DOE-RL approved the requirements, with DOE Environmental Restoration and Waste Management (EM) and the IRP concurrence, and DOE Environment, Safety and Health - Independent Oversight's (EH-O) overview of the process.

The requirements development process included a review of NRC regulations (Title 10 Code of Federal Regulations [CFR], parts 0-199) and guidance to identify those requirements applicable to new SNF Project facilities under the Regulatory Policy. The applicable NRC requirements were compared with DOE requirements to identify significant differences. The DOE requirements and additional NRC requirements identified to establish nuclear safety equivalency are then applied to the SNF Project.

- SARs and TSRs are required to be developed, formally documenting the safety analysis and the proposed design implementation of the established requirements for new facilities. The SARs and TSRs will be prepared, internally approved, and submitted by the Contractor to DOE and the IRP for review and comment, followed by DOE approval and IRP concurrence.

- DOE's independent oversight of this process will be provided by EH-O.

- DOE EH Technical Support (EH-T) will provide technical support resources to supplement the resources of DOE-RL and EM in the development and review of safety documentation and technical requirements.

- DOE-RL will authorize construction and operation of the SNF Project facilities (CVD, CSB, HCS), in accordance with DOE Order 4700.1A, Project Management System, and RLID 5480.31, Startup and Restart of Facilities Operational Readiness Reviews and Readiness Assessments (DOE 1994). 


\subsection{NRC NUCLEAR SAFETY EQUIVALENCY}

DOE's Regulatory Policy (DOE 1995) defined NRC nuclear safety equivalency as:

- Technical requirements that meet the nuclear safety objectives of the NRC regulations for fuel treatment and storage facilities. These include requirements regarding radiation exposure limits, safety analysis, design, and construction.

- Administrative requirements that meet the objectives of the major elements of the NRC licensing process. These include formally documented design and safety analyses, independent technical review, and the opportunity for public involvement.

Technical requirements, in the context of the Regulatory Policy, are the design and construction measures (as opposed to pre-operational or operational measures) that are mandated by the NRC regulations. In addition, the Regulatory Policy specifically excludes those requirements that address environmental, Occupational Safety and Health Administration, chemical accident safety, and other non-nuclear safety issues.

Further, the NRC guidance that provides an acceptable means for implementing the regulations was defined as optional rather than mandatory in the Regulatory Policy. However, NRC guidance that was directly relevant to SNF Project activities (e.g., NRC Regulatory Guide 3.60, Design of an Independent Spent Fuel Storage Installation [Dry Storage]) was reviewed, and additional criteria believed necessary to achieve nuclear safety equivalency were evaluated for incorporation, as a prudent step in implementing the Regulatory Policy's objectives.

\subsubsection{Nuclear Safety Equivalency Scope}

The implementation approach for the Regulatory Policy (DOE 1995) is documented in the Spent Nuclear Fuel Project Regulatory Strategy (WHC 1995a). This strategy required a comparative evaluation of the NRC regulations against DOE's requirements, to determine additional NRC regulatory requirements (beyond the DOE's requirements) that apply to the SNF Project. In cases where the NRC requirements are more stringent than DOE requirements, the NRC requirements will be selected and applied. Consistent with the Regulatory Policy, a comprehensive evaluation of $10 \mathrm{CFR}$, Parts 0-199, and potentially relevant NRC guidance (including NRC Regulatory Guides, NRC NUREG and SECY documents, Standard Review Plans, Inspection and Enforcement Notices and Bulletins) was conducted and compared with the applicable DOE requirements. The results of the evaluation are documented in four reports:

- WHC-SD-SNF-DB-002, Spent Nuclear Fuel Project Path Forward, Nuclear Safety Equivalency to Comparable NRC-Licensed Facilities (WHC 1995e); 
- WHC-SD-SNF-DB-003, Spent Nuclear Fuel Project Path Forward, Additional NRC Requirements (WHC 1995f);

- WHC-SD-SNF-DB-004, Spent Nuclear Fuel Project Seismic Design Criteria, Nuclear Regulatory Commission Equivalency Evaluation Report (WHC 1995h); and

- WHC-SD-SNF-DB-005, Multi-Canister Overpack, Additional NRC Requirements (WHC 1995g).

The first report documents the equivalency review and identifies "Actions for Consideration" that may be necessary to demonstrate nuclear safety equivalency. The second report presents the SNF Project's position on each "Action for Consideration" identified in the first report and transforms those items identified for implementation into a requirements format for the CSB, CVD, and HCS. The second report also includes requirements applicable to the FRS and post-retrieval fuel handling activities. The third report provides an evaluation of seismic design criteria and establishes the basis for application of the recommended criteria for the SNF Project. The fourth report is similar to the second, but specifically considers equivalency as it pertains to the MCO. These reports have been incorporated into the SNF Project technical baseline via Engineering Change Notice ECN-191391.

\subsubsection{Nuclear Safety Equivalency for New SNF Project Facility SARs}

As an element to achieve NRC nuclear safety equivalency, WHC-SD-SNF-DB-003, Spent Nuclear Fuel Project Path Forward, Additional NRC Requirements (WHC 1995f), requires the CSB SAR to include the information unique to SNF storage that is called for in 10 CFR 72, Section 72.24 and the related Regulatory Guide 3.48, Standard Format and Content for the Safety Analysis Report for an Independent Spent Fuel Storage Installation (Dry Storage), which is not required in DOE Order 5480.23, Nuclear Safety Analysis Reports, and related DOE-STD-3009-94, Preparation Guide for U.S. Department of Energy Nonreactor Nuclear Facility Safety Analysis Reports.

To guide preparation of the CSB SAR, relative to format and content, an annotated outline will be prepared. In this outline, additional information required by and selected from 10 CFR 72.24 and Regulatory Guide 3.48 will be noted for the appropriate sections of the SAR. The annotated outline will be used as guidance for the CSB SAR authors.

WHC-SD-SNF-DB-003 (WHC 1995f) also requires that the CVD and HCS SARs include relevant information called for in NRC Regulatory Guide 3.26, Standard Format and Content of Safety Analysis Reports for Fuel Reprocessing Plants, related to 10 CFR 50, Domestic Licensing of Production and Utilization Facilities, which is unique to the conditioning processes in the CVD and HCS facilities, but not specifically required in DOE Order 5480.23. 
Annotated outlines will also be prepared for the CVD and HCS facilities to support the development of the SAR chapters.

\subsection{AUTHORIZATION PROCESS}

This section provides a description of the process to develop and maintain the authorization basis of the SNF Project facilities and activities. Requirements for performing safety analysis, preparing safety documentation, and obtaining the necessary approvals and authorizations for new SNF Project facilities, $\mathrm{K}$ Basins modifications, facility operations, and transportation activities are identified below. The environmental documentation required for authorization of SNF Project activities is described in Section 4.0. The design, construction, and operation phases will be authorized under current DOE statutory authority and existing DOE administrative processes. The DOE requirements will be augmented with NRC requirements, as necessary, to achieve nuclear safety equivalence in accordance with the SNF Project Regulatory Policy.

The authorization activities are divided into two distinct groups:

- K Basins operations and $\mathrm{K}$ Basins modifications.

- New facilities design, construction, and operations.

$\mathrm{K}$ Basins activities are performed in accordance with the existing authorization basis requirements (i.e., $\mathrm{K}$ Basins SAR/OSR and $\mathrm{K}$ Basins S/RID), as amended to address the new activities. New facilities and transportation activities will be performed in accordance with the new authorization basis developed and maintained in accordance with this ISMP.

\subsubsection{Public Involvement}

Public involvement will be a part of the safety and environmental review processes for the SNF Project. Public involvement will be achieved through routine review of the SNF Project plans and implementation results by the Hanford Advisory Board, which includes representation by key Hanford stakeholder groups. Key safety documents (e.g., SARs, Safety Evaluation Reports [SERs], etc.) will be made available in the Public Reading Room, and public inputs will be routinely solicited through a series of publicized public meetings. These activities are further defined in the Spent Nuclear Fuel Project Tribal, Stakeholder and Regulatory Communication and Participation Strategy (WHC 1995i). 


\subsubsection{Authorization Basis Approach}

The following sections define the safety authorization process and the documents comprising the Authorization Basis for SNF Project facilities. The approach to authorization includes development and approval of this documentation and implementation of the safety programs and related procedures to support safe operation.

Activities to be authorized include design, construction, and operation. Each activity may be authorized based on a different set of documents.

Table 2-1 provides the authorization approach for subproject modifications of the $\mathrm{K}$ Basins. Table 2-2 provides the authorization approach for the new facilities, MCOs, transportation, and packaging activities.

\subsubsection{Facility/Project Authorization Basis}

Specific elements of the safety authorization process are described below.

K Basins operations: Operation activities will be governed by the existing $\mathrm{K}$ Basins authorization basis (i.e., $\mathrm{K}$ Basins SAR/OSR, $\mathrm{K}$ Basins S/RID, as approved by the DOE), policies, and implementing procedures. The K Basins SAR and OSR are entitled, Safety Analysis Irradiated N Reactor Fuel, WHC-SD-WM-SAR-062 (WHC 1996c), and Operational Safety Requirements - 100-KE and 100-KW Fuel Storage Basins, WHC-SD-WM-OSR-006 (WHC 1996d).

K Basins FRS and MCO loading modifications: Design will be authorized based on DOE approval of Critical Decisions $1 / 2$ and contractor approval of the FRD, developed to include the applicable functions and requirements (i.e., codes, standards, etc.) from the SNF Project technical baseline and $K$ Basins S/RID. The FRD will be reviewed and approved by Project Management, Design Authorities, K Basins Operations, and K Basins Standards and Requirements personnel, including RI\&PI (as appropriate), Independent Safety, and Quality Assurance (QA).

Construction will be authorized based on DOE approval of the safety documentation (defined in Table 2-1, Table 2-2, and Section 2.5.8) that is tailored to the hazards of the modification to be authorized. The design and safety documentation will be reviewed and approved by Project Management, Design Authorities, K Basins Operations, Fuel Handling Operations, and K Basins Standards and Requirements personnel, including RI\&PI (as appropriate), Independent Safety, and QA personnel.

Operation will be authorized based on DOE approval of facility SAR/TSR revision, S/RID update (as necessary), and Operational Readiness Review (ORR) (as necessary). The 
Table 2-1. K Basins Modifications - SNF Project Authorization Approach.

\begin{tabular}{|c|c|}
\hline Program Element & Authorization Approach \\
\hline $\begin{array}{l}\text { K Basins Modifications } \\
\text { (K Basins Essential } \\
\text { Upgrades and Dose } \\
\text { Reduction System) }\end{array}$ & $\begin{array}{l}\text { - Hazard Category. } \\
\text { - Unreviewed Safety Question (USQ) Screening. } \\
\text { - SAR amendment by annual update, as needed.' }\end{array}$ \\
\hline Fuel Retrieval System & $\begin{array}{l}\text { - Hazard Analysis/Categorization. } \\
\text { Design - authorized based on DOE-RL Spent Nuclear Fuel Project Division } \\
\text { (SFD) approval of Critical Decision } 1 / 2 \text { and Contractor approval of the FRD. } \\
\text { Supporting information will include the Conceptual Design Report (CDR) and } \\
\text { Preliminary Safety Evaluation (PSE). } \\
\text { Procurement - authorized based on DOE-RL SFD approval of Critical } \\
\text { Decision 3a. Supporting information will include Contractor-approved } \\
\text { drawings and specifications, and draft safety analysis, as needed. } \\
\text { Construction - authorized based on DOE-RL SFD approval of Critical } \\
\text { Decision 3b. Supporting information will include Contractor-approved design } \\
\text { and Contractor-approved USQ Screening. } \\
\text { Operation - authorized based on DOE approval of Critical Decision } 4 . \\
\text { Supporting information will include Contractor-approved design, DOE-RL } \\
\text { approved SAR/TR revisions, }{ }^{1,2} \text { S/RID update (as needed), and ORR. }\end{array}$ \\
\hline $\begin{array}{l}\text { Integrated Water Treatment } \\
\text { System }\end{array}$ & $\begin{array}{l}\text { Hazard Category. } \\
\text { Design - authorized by DOE approval of FRD or FDC. } \\
\text { - Construction - authorized based on completion of KR-3 in the K Basins Plant } \\
\text { Project Review Process. Supporting information includes a Contractor- } \\
\text { approved USQ screening. } \\
\text { Operation - DOE approval of SAR revisions.2 and ORR, as needed. }\end{array}$ \\
\hline Debris Removal System & $\begin{array}{l}\text { - Hazard Category. } \\
\text { - USQ Screening. } \\
\text { - SAR annual update. if needed. } \\
\end{array}$ \\
\hline Sludge Removal System & $\begin{array}{l}\text { - Hazard Category. } \\
\text { Design - authorized by DOE approval of FRD or FDC. } \\
\text { Construction - authorized based on completion of KR-3 in the K Basins Plant } \\
\text { Project Review Process. Supporting information includes a Contractor- } \\
\text { approved USQ screening. } \\
\text { Operation - DOE approval of SAR/TSR revisions }{ }^{1,2} \text { and ORR, as needed. } \\
\text { Tank Waste Remediation System (TWRS) acceptance of sludge }{ }^{4} \text { - authorized } \\
\text { based on Safety Evaluation USQ and DOE approval of Safety Assessment and } \\
\text { amendment of TWRS Integrated Safety Basis/TSRs or Integrated Operating } \\
\text { Safety Requirements, as needed. Also includes preparation and approval of the } \\
\text { CSER. }\end{array}$ \\
\hline
\end{tabular}

A graded approach will be used to upgrade the K Basins SAR and OSR relative to full compliance with DOE Order 5480.22 and 5480.23 and related rules, prior to completion of fuel removal from the $K$ Basins.

2 The K Basins SAR/TSR revision will be developed by integrating the various impacts from the FRS, IWTS, MCO Assembly, MCO Topical, Cask/MCO handling. SARP(s), and CVD on the K Basins during the annual updates to the SAR.

3 This work is covered by the existing SAR/OSR.

- TWRS acceptance of the K Basins sludge is not part of the K Basins authorization basis; however, it will impact approval to start operations. 
Table 2-2. New Facility, MCO, and Transportation and Packaging Authorization Approach (2 Sheets).

\begin{tabular}{|c|c|}
\hline Program Element & Anthorization Approach \\
\hline $\begin{array}{l}\text { Cold Vacuum Drying } \\
\text { Facility }\end{array}$ & $\begin{array}{l}\text { Design - authorized based on DOE-RL SFD approval of Critical } \\
\text { Decision } 1 / 2 \text {. Supporting information will include the Contractor- } \\
\text { approved performance specification and completed conceptual design. } \\
\text { - PSE and Preliminary Hazards Assessment (PHA) to be provided to } \\
\text { support development of definitive design. } \\
\text { - Construction - authorized based on DOE-RL SFD approval of Critical } \\
\text { Decision 3. Supporting information will be the phased SAR submittal. } \\
\text { - Operation - authorized based on DOE approval of Critical Decision } 4 \text {. } \\
\text { Supporting information will include the MCO Topical Report, SARP, } \\
\text { SAR/TRS, S/RID, and ORR. }\end{array}$ \\
\hline $\begin{array}{l}\text { SNF Multi-canister } \\
\text { Overpacks }\end{array}$ & $\begin{array}{l}\text { Design - authorized based on DOE-RL SFD approval of Critical } \\
\text { Decision } 1 / 2 \text { and FRD. Supporting information will include the DOE-RL } \\
\text { approved Phase I design and Contractor-approved performance } \\
\text { specification. } \\
\text { Procurement - authorized based on DOE-RL SFD approval of Critical } \\
\text { Decision } 3 \text {. Supporting information will include the MCO Topical Report } \\
\text { and Contractor-approved definitive design. Long-lead procurement of } \\
\text { materials may take place in advance of completion of definitive design and } \\
\text { the Topical Report, with DOE-RL approval. } \\
\text { The MCO Topical Report will provide documentation of the MCO design and } \\
\text { safety features that will be referenced by the K Basins, CSB, CVD, and HCS } \\
\text { SARs. }\end{array}$ \\
\hline
\end{tabular}

1 Use of a single SAR (e.g., no Preliminary Safety Analysis Report) is specifically allowed by DOE Order 5480.23. DOE approval of the use of a single SAR approach was granted for the SNF Project facilities by a memorandum from J. E. Lytle to T. P. Grumbly (Lytle 1995). The single SAR approach is similar to the site-specific NRC 10 CFR 72 licensing process for commercial fuel storage facilities. Several exemptions from DOE Order 4700.1 requirements were requested by the SNF Project letter of January 31, 1995 (Fulton 1995). This request to streamline the DOE project management process was addressed and approved by the March 1995 memorandum from Lytle to Grumbly (Lytle 1995). 
Table 2-2. New Facility, MCO, and Transportation and Packaging Authorization Approach (2 Sheets).

\begin{tabular}{|c|c|}
\hline Program Element & Authorization Approach \\
\hline $\begin{array}{l}\text { Cask and Transportation } \\
\text { Systems }\end{array}$ & $\begin{array}{l}\text { Design - authorized based on DOE-RL SFD approval of Critical } \\
\text { Decision 1/2. Supporting information will include the DOE-RL approved } \\
\text { Packaging Design Criteria and performance specification, and Contractor- } \\
\text { approved preliminary design. } \\
\text { Fabrication - authorized based on DOE-RL SFD approval of Critical } \\
\text { Decision 3. Supporting information will include the Contractor-approved } \\
\text { final design. Long-lead procurement of materials may take place in } \\
\text { advance of completion of definitive design with DOE-RL approval. } \\
\text { Operation - authorized based on DOE approval of Critical Decision } 4 . \\
\text { Supporting information will include SARP(s), K Basins SAR/OSR } \\
\text { amendment, CVD and CSB SAR/TSRs, and ORR, as appropriate.' }\end{array}$ \\
\hline $\begin{array}{l}\text { Canister Storage } \\
\text { Building }\end{array}$ & $\begin{array}{l}\text { Design - authorized based on DOE approval of the FRD and Key } \\
\text { Decisions } 1 / 2 \text {. } \\
\text { Construction - authorized based on DOE approval of phased SAR } \\
\text { submittals, Key Decisions 3a and 3b, and Critical Decisions } 3 \mathrm{c} \text { and } 3 \mathrm{~d} \text {. } \\
\text { Operation - authorized based on DOE approval of the completed MCO } \\
\text { Topical Report, SARP, SAR/TSRs, S/RIDs, and ORR, as appropriate, and } \\
\text { Key Decision 4.' }\end{array}$ \\
\hline $\begin{array}{l}\text { Hot Conditioning } \\
\text { System Facility }\end{array}$ & $\begin{array}{l}\text { Design - CSB Annex authorized based on DOE-RL SFD approval of } \\
\text { Critical Decisions Ia/2a and Contractor-approved performance } \\
\text { specifications. HCS process design authorized based on DOE-RL SFD } \\
\text { approval of Critical Decisions } 1 \mathrm{~b} / 2 \mathrm{~b} \text {. Supporting information will include } \\
\text { the DOE-RL approved FRD and Contractor-approved CDR. } \\
\text { - PSE and PHA to be provided during the HCS process conceptual design to } \\
\text { support development of definitive design. } \\
\text { Construction - authorized based on DOE-RL SFD approval of Critical } \\
\text { Decisions 3a for the HCS Annex to the CSB and } 3 b \text { for the HCS process } \\
\text { system. Supporting information will include the Contractor-approved } \\
\text { definitive design and phased SAR submittal.' } \\
\text { Operation - authorized based on DOE approval of Critical Decision } 4 \text {. } \\
\text { Supporting information will include the MCO Topical Report, SAR/TSRs, } \\
\text { S/RID, and ORR, as appropriate.' }\end{array}$ \\
\hline $\begin{array}{l}\text { Other Spent Nuclear } \\
\text { Fuel }\end{array}$ & See Section 2.5.15. \\
\hline
\end{tabular}

1 Use of a single SAR (e.g., no Preliminary Safety Analysis Report) is specifically allowed by DOE

Order 5480.23. DOE approval of the use of a single SAR approach was granted for the SNF Project facilities by a memorandum from J. E. Lytle to T. P. Grumbly (Lytle 1995). The single SAR approach is similar to the sitespecific NRC 10 CFR 72 licensing process for commercial fuel storage facilities. Several exemptions from DOE Order 4700.1 requirements were requested by the SNF Project letter of January 31, 1995 (Fulton 1995). This request to streamline the DOE project management process was addressed and approved by the March 1995 memorandum from Lytle to Grumbly (Lytle 1995). 
SAR/TSR, S/RID, and ORR will be reviewed and approved by K Basins Operations Management, Project Management, Design Authorities, and Standards and Requirements, including RI\&PI (as necessary), Independent Safety, and QA personnel.

K Basins IWTS and SRS Modifications: The IWTS and SRS will be approved by DOE consistent with requirements defined by project-specific Project Management Plans. Each subproject PMP calls out the level of review and approval required (for specific activities/documentation). These projects shall follow the administrative procedure on the $\mathrm{K}$ Basins Plant Project Review Process to ensure configuration control of activities during design, construction, and operation of the modification.

Approval to transfer K Basins sludge to the Tank Waste Remediation System tank farms will be in accordance with a memorandum of understanding (MOU) with the TWRS Project (Fulton 1996a). The SNF Project is responsible for preparation and obtaining approval of the safety documentation associated with this transfer. This includes the SARP for transfer of the sludge and modifications to the TWRS safety authorization basis (see Table 2-1). The TWRS safety documentation to be prepared/modified includes: Preliminary Hazards Assessment (PHA), Hazard Category, USQ screening, Safety Assessment, Topical Report for the TWRS Facility Safety Analysis Report, and a CSER.

Other K Basins modifications: Other $\mathrm{K}$ Basins modifications within Contractor authority (e.g., pump replacement to support continued $\mathrm{K}$ Basins operations) will be authorized based on $\mathrm{K}$ Basins procedures.

New SNF Project facilities (CVD, CSB, HCS): Design will be authorized based on DOE approval as shown in Table 2-2. The requirements (i.e., codes, standards, etc.) will be reviewed and approved by Project Management, Design Authorities, Fuel Handling Operations, RI\&PI, K Basins Standards and Requirements (as necessary), Independent Safety, and QA personnel.

Construction (stages, as necessary) will be authorized based on DOE approval of the key decisions or critical decisions and safety documentation (defined in Table 2-1, Table 2-2, and Section 2.5.8) that are tailored to the hazards of the facility (for the corresponding stage of construction) to be authorized. The design and safety documentation will be reviewed and approved by Project Management, Design Authorities, Fuel Handling Operations, RI\&PI, $\mathrm{K}$ Basins Standards and Requirements (as needed), Independent Safety, and QA personnel.

Operation will be authorized based on DOE approval of facility SAR/TSR, S/RID, and Operational Readiness Review (ORR). The basis for DOE's approval will be documented in a DOE SER. The SAR/TSR, S/RID, and ORR will be reviewed and approved by Fuel Handling Operations Management, Project Management, Design Authorities, RI\&PI, K Basins Standards and Requirements (as required), Independent Safety, and QA personnel. 
SNF multi-canister overpacks: Design and procurement will be authorized as shown in Table 2-2. Design requirements, design, and safety documentation (MCO Topical Report) will be approved by Project Management, Design Authorities, Fuel Handling Operations, RI\&PI, $\mathrm{K}$ Basins Standards and Requirements, Independent Safety, and QA personnel.

"Operation" of the MCOs is directly linked to other SNF Project activities and will be authorized as part of each of these other functions. For example, loading fuel baskets into the MCOs will be authorized as part of the overall fuel retrieval and MCO-loading operations at the $\mathrm{K}$ Basins, as described in Table 2-1.

\subsubsection{Authorization Basis Development Process}

The process of developing the authorization basis include the following activities:

- Definition of a Requirements Basis - The requirements source documents (codes and standards, etc.) establish the requirements for design, safety analysis, environmental permitting, construction, and operation. The requirements basis is the SNF technical baseline and, for the work at the K Basins, the K Basins S/RID.

- Establishment of Functions and Requirements (FRD/FDCs) - Systems engineering analysis identifies the functions to be performed and the specific requirements to be met from the requirements basis.

- Develop Design and Safety Analysis Documents - The functions and requirements establish the scope and requirements to be met by the design and safety analysis documents. The functions and requirements are typically imposed by the performance specifications. The result of these activities is the creation of the detailed design documentation and SAR/TSR (or amendments) that support construction. The FRS, CVD, HCS, and Cask and Transportation detailed designs will start prior to approval of the FRD/FDC documents.

- Development of Operations Control Documentation - Authorization of operation will be based on a comprehensive review (ORR/Operations review, as appropriate) to assure the documentation, systems, and support functions are in place. Key documents supporting operations are the SAR/TSR (or amendments, as needed), the S/RID (or update, as necessary), and operating procedures that implement the safety basis. The SAR/TSR are developed during design. The final S/RID (or update) will be prepared based on all of the previous activities above. The operating procedures are developed during construction, and personnel training is completed during start-up testing. This process is discussed further in Section 2.5.3. 
Environmental permits are a portion of the authorization basis and will be obtained as necessary to support design, construction, and operation activities per the ISMP. Environmental permitting plans for SNF Project facilities and activities are discussed further in Section 4.0.

\subsubsection{Requirements Management}

SNF Project requirements are managed as a part of the Systems Engineering process. Requirements management includes the following:

- Establishing and managing the requirements basis (See Section 2.5.3.1).

- Establishing the functions to be performed and allocating the requirements associated with those functions (See Section 2.5.3.2).

- Developing designs and safety analysis for equipment and systems that perform the functions and implement the requirements (See Section 2.5.3.3).

- Constructing equipment and implementing systems in accordance with the designs and requirements (See Section 2.5.3.4).

- Development/update of S/RIDs (See Section 2.5.3.5).

- Operating the equipment and systems within design and safety limits and requirements (see Section 2.5.3.6), and in accordance with TSR/OSR requirements, per approved operating procedures.

The DOE has applied the Systems Engineering methodology to the Hanford site in response to DNFSB Recommendations 92-4 and 94-1 (Conway 1992 and 1994). Systems Engineering is being implemented at the Hanford site based on this guidance (RLPD 430.1, Hanford Site Systems Engineering Policy [DOE 1996b] and RLID 430.1, Systems Engineering Criteria Document and Implementing Directive [DOE 1996c]) and based on DOE Order 4700.1, Project Management System, where applicable. The systems engineering process for the SNF Project is defined in Spent Nuclear Fuel Project Systems Engineering Management Plan (WHC 1995c).

The SEMP describes the process of identifying, developing, and controlling project functions and requirements, including safety-related functions and requirements. The approved functions and requirements are incorporated into the SNF Project technical baseline (WHC 1996a). This systems engineering baseline includes the top-level functions and requirements and the technical baseline database, which is comprised of functions and requirements at the subproject level. Changes to the technical baseline are controlled in accordance with the SNF Project Configuration Management Plan (WHC 1995j), and its implementing procedures. 
The requirements basis for facility operations, the facility S/RIDs, are a sub-set of the overall systems engineering baseline. The S/RIDs will be derived from the technical baseline as the facilities transition from construction and start-up testing to operations. The S/RIDs are also controlled in accordance with the SNF Project Configuration Management Plan and its implementing procedures. Additional discussion of the SNF Project S/RIDS is provided in Section 2.5.3.5.

\subsubsection{Requirements Basis}

The requirements basis is the set of documents established as the source of the requirements to be applied to an activity. The requirements basis applicable to the SNF Project facilities is defined in the Spent Nuclear Fuel Project Technical Baseline Document, Fiscal Year 1996, WHC-SD-SNF-SD-00S (WHC 1996a), and the K Basins S/RID, WHC-SD-SNF-RD-001 (WHC 1995k). DOE-RL has reviewed and approved the SNF Project technical baseline and the $\mathrm{K}$ Basins S/RID. For the $\mathrm{K}$ Basins, the safety requirements basis is the $\mathrm{K}$ Basins $\mathrm{S} / \mathrm{RID}$. The SNF Project technical baseline and K Basins S/RID are the initial source documents used to establish the functions and requirements for all of the SNF Project subprojects.

An independent review process will ensure that the requirements basis for the $\mathrm{MCO}$, CSB, CVD, and HCS includes the requirements necessary to meet NRC nuclear safety equivalency (see Section 2.4.2). The approval process for the NRC equivalency requirements basis is shown conceptually in Figure 2-1.

The SNF Project requirements basis are under the configuration control and change management processes to assure that changes are properly reviewed, approved, and included in the technical baseline. Technical baseline changes will result in updates to the design and safety analysis products, as necessary.

\subsubsection{Functions and Requirements Analysis}

The development of the project mission, functions, and requirements, and the evolution of the system architecture through the design process, requires identification of requirements at each step. Detailed definitions of the requirements that apply are established by system engineering reviews of the requirements basis included in the SNF Project technical baseline, Section 3.5.4 (WHC 1996a), and the K Basins S/RID (WHC 1995k). Requirements will be selected and applied to functions in accordance with the SNF Project SEMP (WHC 1995c). The functions and requirements for the SNF Project facilities and activities will first be developed and documented in controlled FRDs, performance specifications, or FDCs, which will form the basis for facility and equipment design. The FRDs, performance specifications, or FDCs are used by DOE to approve the design bases. This process is used for new SNF Project systems and facilities, and for modification to the $\mathrm{K}$ Basins systems associated with FRS, SRS, DRS, and IWTS. 
Figure 2-1. Review and Approval of SNF Project New Facility Requirements Basis for NRC Equivalency.

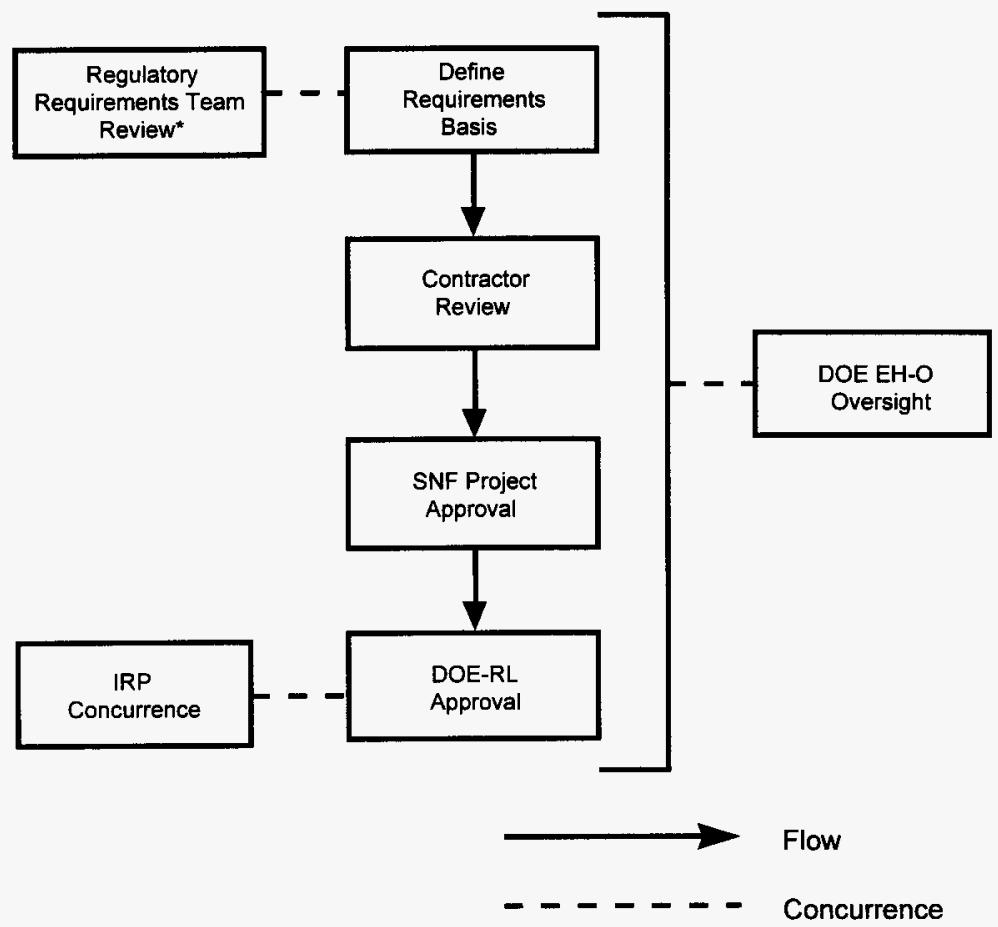

* Regulatory Requirements Team includes DOE-EM, DOE-EH-T, Contractor, and subcontractor representation. 


\subsubsection{Requirements Management During Design}

Design and procurement requirements for the SNF Project facilities and equipment will comply with the FRD/FDC requirements. During the design process, additional levels of detailed requirements will be developed, as needed, that are included in design configuration baseline documents, such as design drawings and specifications. The detailed requirements resulting from design activities are maintained in the design configuration baseline. DOE approval of the designs are provided by the key decision and/or critical decision processes.

It is common for design and safety analysis to require the definition of assumptions in order to support design and safety analysis activities. Assumptions are controlled in accordance with the SNF Project SEMP (WHC 1995c). Tracking assumptions to closure provides assurance that the designs and safety analysis are complete and based on solid technical principles, characterization activities, or test demonstrations.

Control interface is performed in accordance with the Spent Nuclear Fuel Project Interface Control Plan, WHC-SD-SNF-CM-003 (WHC 1995I). Interface requirements and changes to the interface requirements will be provided to the designers. Assessment of the impacts of these changes will include an assessment of the impacts on the safety basis. Design authorities maintain configuration control of the project design media until it has been issued as the design configuration baseline. After the design media has been issued as the design configuration baseline, any design changes are controlled in accordance with the SNF Project Configuration Management Plan (WHC 1995j). The requirements baseline will continue to be defined and managed in accordance with the SEMP (WHC 1995c).

Following initial issuance of the safety documents, any changes resulting from the identification of safety issues or changes to the facility design will be evaluated for impacts to the safety basis. Design authorities will track the resolution of safety issues and changes to the safety basis. Changes to the safety basis will be documented and approved in accordance with the SNF Project Configuration Management Plan (WHC 1995j) before release of the affected design media for procurement or construction. The safety documentation will be revised as appropriate to include information for closure of items requiring further resolution. Changes to the safety basis, technical baseline, and other safety documentation subsequent to the release of design media for procurement and/or construction will comply with the requirements of the SNF Project Configuration Management Plan (WHC 1995j).

The design of the CVD, CSB, and HCS facilities will be developed in phases. Typically, the first phase is the conceptual design based on the FRD or FDC. Conceptual design activities include the preparation of a PHA, the Hazards Categorization of the proposed facilities, and the Preliminary Safety Evaluation (PSE). The PSE provides the first evaluation of the unmitigated consequences of potential bounding accidents for the conceptual system and facility designs. The conceptual design is then updated to include preventive and/or mitigating features to reduce the consequences of the bounding accidents to acceptable levels. Additional analyses are performed 
as part of the PSE (or follow-on safety analyses) to confirm the effectiveness of the mitigating features.

For projects with abbreviated conceptual design phases (i.e., the CSB), the PSE is prepared based on detailed engineering studies. The results of the PSE are used during the early phases of definitive design in the same fashion discussed above.

Preliminary design is typically the second phase. Preliminary design activities further develop the design defined in the conceptual design. Depending on the complexity of the design and technological uncertainties, the preliminary design phase may require proof testing to validate certain design approaches. As the preliminary design progresses, continuous interaction occurs between design and safety analysis personnel. Safety analyses are performed as required to support design alternative evaluations. Designs and safety analyses are subjected to an ongoing review and feedback process by the design teams, the safety analysis personnel, and the independent safety reviewers during the preliminary design phase.

The last design phase is detailed design. Typical activities include the resolution of assumptions and issues, resolution and incorporation of the design review comments, incorporation of the test results, and completion of the detailed design outputs. As the design phases progress into detailed design, preparation of the accident analysis portion of the SAR is initiated. Improvements to the design resulting from the SAR development, review, and comment resolution processes are also included in this phase. The details of this approach will vary for each facility depending on project size and specific scope.

The development, approval, and change control requirements for design and safety analyses are provided in the SNF Project SEMP (WHC 1995c), the SNF Project Configuration Management Plan (WHC 1995j), the Standard Engineering Practices Manual (WHC 1995m), the SNF Project Quality Assurance Program Plan (WHC 1996b), and the Safety Analysis Manual (WHC 1996e).

The design activities for the $\mathrm{K}$ Basins Modifications, FRS, SRS, DRS and IWTS may use a modified form of the design/safety analysis process described above. For example, the FRS plans to develop the FRD, conceptual design and PHA/PSE concurrently, with the detailed design beginning slightly before the completion and approval of the FRD and Conceptual Design Report. The project management plans for these subprojects will define any unique steps planned for the design, development, and safety analysis processes. These plans will be reviewed and approved in accordance with the requirements of the SNF Project PMP (WHC 1995d).

Design documents developed by subcontractors are reviewed and approved through a process defined by specifications, vendor contractual provisions, and the Contractor design/configuration control manuals. Subcontractor designs are developed and controlled according to the requirements of their configuration management system. Contractor design activities are controlled under the provisions of WHC-CM-6-1, Standard Engineering Practices Manual (WHC 1995m), the SNF Project - Project Management Plan (WHC 1995d), and the 
SNF Project Configuration Management Plan (WHC 1995j). Design reviews will be performed at several stages during the course of design development (e.g., typically at the $30 \%$ and $90 \%$ completion stages of each design phase).

The safety-related design basis is documented in the SAR, in accordance with DOE Order 5480.23. DOE approval of the SAR reflects approval of that safety-related design basis and design descriptions.

\subsubsection{Requirements Management During Construction}

Following completion of the design activities and DOE's approval of the key/critical decisions, construction begins. Design changes that occur during construction will be evaluated for impact on the project safety basis and technical baseline. The SAR will be updated in accordance with the requirements of the SNF Project Configuration Management Plan (WHC 1995j) to reflect design changes and construction results as these efforts progress. Organizational responsibility for the requirements management processes are described in Section 1.5. Quality Assurance applied during the construction phase and as-built efforts will provide reasonable assurance that the constructed facility and equipment comply with the design and SAR requirements. In addition, equipment acceptance testing and facility cold test programs will be used to provide further assurance that the design and SAR requirements are met.

\subsubsection{Development of Standards/Requirements Identification Documents}

The DOE has implemented a standards and requirements management program in conformance with the DNFSB Recommendation 90-2 (Conway 1990). The objectives of this program are to identify the specific environmental, safety, and health-related standards and requirements to which the facilities were designed, constructed, and operated; to assess the adequacy of the standards to ensure the protection of public and worker health and safety and the environment; and to determine the extent to which these codes and standards have been implemented in the field. The standards and requirements identified under this program are collected in a document known as the S/RID. The S/RID defines the requirements agreed to by the Contractor and DOE. The S/RID is implemented through Contractor policies and procedures.

The SNF Project S/RIDs capture the applicable safety requirements of the DOE orders and regulations, Code of Federal Regulations, and the WAC, among other requirements source documents, that embody the necessary and sufficient requirements to ensure the safety of the public and worker and protection of the environment. The SNF Project S/RIDs and other applicable safety documentation will be used in the process to define the authorization basis for the new facilities or nuclear activities, which in combination with the readiness assessments, allows DOE to approve proceeding with the various SNF Project operations. 
The S/RID development efforts will be managed as a joint effort between the SNF Project's Systems Engineering and regulatory management personnel. An S/RID will be developed for new facilities based on information derived from the technical baseline database. The S/RID for the K Basins was approved in 1995 (Wagoner 1995).

The technical baseline database maps performance requirements, design standards, safety requirements, and regulatory requirements to the project functional breakdown structure, in accordance with the requirements of the SNF Project SEMP (WHC 1995c). The project functions will be cross-referenced to the twenty generic functional areas of the S/RIDs. The S/RIDs for new facilities are then derived from the project technical baseline database prior to initiation of operations.

\subsubsection{Operational Requirements Management}

Once a SAR is approved, changes will be processed in accordance with the requirements of the SNF Project Configuration Management Plan (WHC 1995j) and WHC-CM-6-1, Standard Engineering Practices Manual (WHC 1995m). Changes to the facility or its operating bases that may have an impact on the authorization basis of the facility will require a USQ evaluation screening as directed by DOE Order 5480.21, Unreviewed Safety Questions, and implemented through WHC-CM-1-5, Standard Operating Procedures, Section 7.3, "Identifying and Resolving Unreviewed Safety Questions" (WHC 1996f).

The SAR will be reviewed annually and updated as necessary pursuant to the requirements of DOE Order 5480.23, Nuclear Safety Analysis Reports. Changes to the SAR that are processed in accordance with the WHC-CM-6-1 manual (including USQ evaluations, amendments to TSRs, and other significant changes) will be accumulated and considered as an addendum to the SAR until the information is incorporated into the subject SAR as part of the next annual update.

The SNF Project technical baseline will be maintained to reflect modifications to the facility configuration during the operations phase. Approved changes to the technical baseline, changes to the requirements source documents, or the addition/deletion of the requirements source documents will be evaluated for the need to change the S/RID per Administrative Procedure 1-013-00, Establishment, Maintenance, and Control of S/RID Database (WHC 1995n).

The SNF Project operating procedures will implement the safety requirements from the TSRs/OSRs and the S/RIDs, during operation of the SNF facilities and systems.

Operational compliance reviews will provide assurance that the SNF Project facilities are operating in accordance with their authorization basis requirements. These reviews are conducted in accordance with Contractor procedures during the project ORRs and during facility operations. 


\subsubsection{Safety Analysis Process and Documentation}

DOE Order 5480.23, Nuclear Safety Analysis Reports, and its implementing standards provide guidance in using a "graded approach" to safety analysis and safety analysis reports. The primary objective of using a graded approach to the safety analysis process is to select and apply an analysis technique that provides sufficient detail to assess each postulated accident or failure, the resulting consequences, and means of prevention and mitigation. The level of effort, sophistication of the analysis, and the level of detail of the SARs are graded following the direction provided in DOE Order 5480.23 with the following considerations: (1) magnitude of the hazard being addressed, (2) complexity of the facility and the safety systems, (3) stage of the facility life cycle, and (4) programmatic mission of the facility.

This section presents the safety analysis process for the SNF Project. The detailed schedules for preparation, review, and approval of the safety analyses are included in the Integrated Project Schedule. Figure 2-2 illustrates typical safety analysis and documentation process that will be required for new $\mathrm{DOE}$ facilities including the requirements established in DOE Order 5480.23. The major steps in the process are discussed below, with SNF Projectspecific features noted. Section 2.5 .8 provides the requirements and description of the safety analysis and documentation approach for the SNF Project.

- Safety Evaluation USQ - (K Basins modifications and future CVD, CSB, and HCS modifications only.) In the design phase, USQ screening evaluations will be performed on the K Basins modifications as directed by DOE Order 5480.21 , Unreviewed Safety Questions, and implemented through WHC-CM-1-5, Standard Operating Procedures, Section 7.3, "Identifying and Resolving Unreviewed Safety Questions," (WHC 1996f). Further hazard and safety analysis, and the development of SAR revisions will be required for modifications determined to not be bounded by the safety basis. Changes to design of the $\mathrm{K}$ Basins modifications during the construction phase will also be subject to the requirements of DOE Order 5480.21.

New facilities will implement the USQ process following approval of the completed facility SARs. Control of changes to the design and safety analyses for new facilities will be in accordance with DOE Order 5480.23 and the SNF Project Configuration Management Plan (WHC 1995j) and implementing procedures. Control of the SAR development must address the following excerpts from DOE Order 5480.23:

"All contractors shall be held responsible for adhering to assumptions and commitments set forth in the safety analysis."

"The contractor must submit for DOE approval, a plan to resolve nonconformances, including identification of new evidence bearing on the validity of prior safety analyses." 
Rev. 2

Figure 2-2. Typical Safety Analysis Process for New Facilities.*

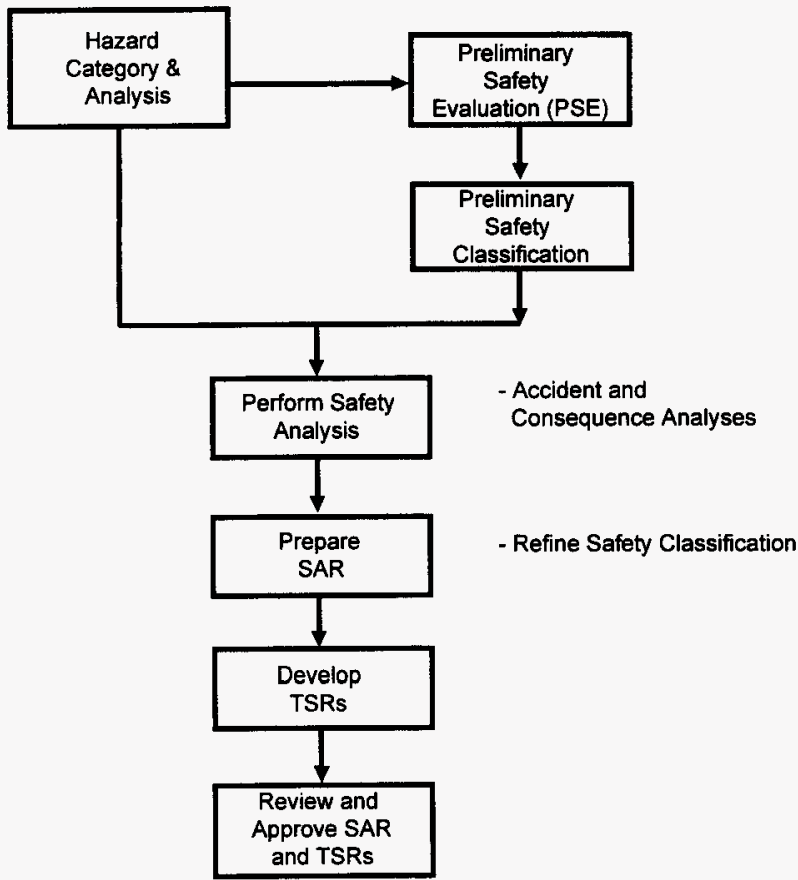

* The SNF Project will prepare, review, and approve SAR chapters using a phased approach that supports expedited construction and operation of new facilities. 
- Hazards Analysis - In the conceptual design phase, a preliminary hazards analysis is performed to identify potential hazardous conditions and postulated accident scenarios in accordance with DOE-STD-3009-94 as identified in WHC-CM-4-46 (WHC 1996e), Chapter 3.0, "Safety Analysis Requirements" and Chapter 4.0, "Determining and Documenting Facility Hazard Category."

The preliminary hazards analysis is updated during detailed design and documented in the SAR. The results of the hazard analysis provide the basis for identifying safetyrelated systems, structures, and components; establishing TSR controls; and establishing the level of detail necessary in the SAR.

- Hazard Categorization - The hazard categorization of a facility is based on the inventory of radioactive material present in the facility in accordance with the guidance provided in DOE-STD-1027-92 and as identified in WHC-CM-4-46, Chapter 3.0, "Safety Analysis Requirements," and Chapter 4.0, "Determining and Documenting Facility Hazard Category" (WHC 1996e). The initial facility hazard category may be included in the PSE. Based on the hazard category determination, a graded approach is developed for the analysis used for the safety evaluation. A final hazard categorization is performed during the definitive design/final safety analysis and submitted to DOE for review and approval. DOE approval of the hazard categorization is documented in the SAR.

- Preliminary Safety Evaluation - A preliminary safety evaluation is performed utilizing input from the hazards analysis. The PSE may be part of the conceptual or preliminary design of a modification or facility. The PSE identifies measures that must be incorporated into the design to reduce the impact of the identified hazards. The PSE is performed in accordance with WHC-CM-4-46, Chapter 5.0, "Preliminary Safety Evaluation" (WHC 1996e). A SAR supersedes any corresponding information of a PSE for start of the facility construction.

- Safety Classification - The hazards analysis, PSE, and subsequent accident analyses provide input for the safety classification of the systems, structures, and components. Equipment that must perform a function to prevent or mitigate the consequences of identified hazards are important to safety and are classified as safety equipment.

Safety classifications will be performed in accordance with DOE Order 6430.1A and DOE-STD-3009-94, as implemented by WHC-CM-4-46, Chapter 9.0, "Safety Classification of Structures, Systems and Components" (WHC 1996e).

- Fire Hazards Analysis (DOE Order 5480.7A) - The fire hazards analysis (FHA) comprehensively assesses the risk from fire within individual fire areas in a DOE facility. A graded FHA, that reflects the risks from fire in a facility, shall be performed for new facilities as directed by DOE Order 6430.1A, General Design Criteria, DOE Order 5480.23, Nuclear Safety Analysis Reports, and DOE 
Order 5480.7, Fire Protection. Additional requirements for fire protection are discussed in Section 2.4 .

The FHA is started early in the definitive design when sufficient information is available to determine combustible loadings in the facility. The FHA establishes requirements for fire protection (i.e., fire detection systems, fire suppression systems, and fire barriers) and estimates potential fire losses. Fire protection features are included in the facility design. The FHA is revisited near the completion of the definitive design to confirm the adequacy of the design and to reflect the final design configuration in all analyses.

- Accident Analysis - Events identified by the hazards analysis as having potential onsite and off-site consequences are further developed into accident scenarios. Accident scenario development includes a determination of the accident frequencies. After scenarios are defined and radiological and/or toxicological source terms are developed, consequence analysis is performed to evaluate preventive and mitigating design features and to quantify the impact to the public, on-site workers, and environment. Accident analysis will be performed in accordance with WHC-CM-4-46, Chapter 3.0, "Safety Analysis Requirements" (WHC 1996e), to comply with the requirements of DOE Order 5480.23 and DOE-STD-3009-94. Changes to the design and safety analysis are performed in accordance with the requirements of the SNF Project Configuration Management Plan (WHC 1995j).

- Criticality Safety Evaluation Report - The criticality safety of equipment and operations involving fissionable material for normal and credible abnormal conditions are evaluated in the criticality safety evaluation during definitive design. The evaluation confirms that the equipment design and/or administrative controls meet or exceed the margin of safety required by DOE Order 5480.24 , Nuclear Criticality Safety. Criticality safety evaluations will be performed in accordance with WHC-CM4-29, Nuclear Criticality Safety Manual (WHC 1995o). Additional requirements for criticality safety are discussed in Section 2.4 .

- Safety Analysis Report - The SAR documents the safety-related design basis and the safety analysis for a nuclear facility to ensure that the facility can be constructed, operated, maintained, shut down, and decommissioned safely and in compliance with the applicable laws and regulations. For K Basins modifications, SAR amendment(s) will be prepared and approved in accordance with WHC-CM-4-46 (WHC 1996e) and applicable sections of WHC-CM-3-6, Uniform Publication System (WHC 1995p).

The SARs for new facilities will implement the requirements of DOE Order 5480.23, and follow the format and content requirements of DOE-STD-3009-94, Preparation Guide for U.S. Department of Energy Nonreactor Nuclear Facility Safety Analysis Reports. Additional content and format requirements for the new facility SARs are 
discussed in Section 2.4.1. For the new facilities, a phased SAR approach is planned. See specific facility description in Section 2.5 .8 for details.

- Technical Safety Requirements - The TSRs define the conditions, boundaries, and the management or administrative controls that must be maintained to ensure the safe operation of a nuclear facility. The TSRs are developed in accordance with DOE Order 5480.22, Technical Safety Requirements, and are based on the operational limits identified in the SAR. The final TSRs are contained in a separate document that is approved by DOE prior to facility operations. TSRs will be developed in accordance with WHC-CM-4-46, Chapter 6.0, "Technical Safety Requirements" (WHC 1996e). The K Basins will continue to have OSRs that will be modified or updated by Engineering Change Notices per the guidance of WHC-CM-4-46, Chapter 6.0, until replaced by a K Basins TSR (see Section 2.5.7).

- MCO Topical Report - The MCO Topical Report will document the design and various functions that must be performed by the MCOs during fuel drying, staging, fuel conditioning, and interim storage. The SARs for the CSB, the fuel conditioning facilities, and the K Basins will reference the MCO Topical Report, as necessary.

The MCO Topical Report content areas are listed in Table 2-3. The format was derived from NRC Regulatory Guide 3.61, Standard Format and Content for a Topical Safety Analysis Report for a Spent Fuel Dry Storage Cask. Table 2-3 includes a cross-reference to DOE-STD-3009-94 to illustrate the SAR chapters with the potential for receiving support from or referencing the MCO Topical Report.

- Packaging Design Criteria document - The design of the packaging is based on the Packaging Design Criteria (PDC). The PDC document establishes the methodology used to implement on-site transportation safety requirements. The PDC establishes the specific design features required of the packaging and the acceptance criteria for the package safety analyses. The design and SARP will be prepared and approved in accordance with the requirements set forth in the PDC.

- Safety Analysis Report for Packaging - The SARP documents the safety analysis for handling, transportation, and packaging activities separately in accordance with the direction provided in DOE-RL Letter 95-SWT-186 (Valdez 1995), WHC-CM-2-14, Hazardous Material Packaging and Shipping (WHC 1995q), and WHC-SD-TP-RPT-001, Report on Equivalent Safety for Transportation and Packaging of Radioactive Materials (WHC 1994b). The SARP describes the packaging, evaluates the proposed payload, and documents the results of analysis performed to demonstrate that the package design meets safety requirements. 
Table 2-3. MCO Topical Report Content.*

\begin{tabular}{|c|l|c||}
\hline Chapter & \multicolumn{1}{|c|}{ Title } & $\begin{array}{c}\text { DOE-STD-3009-94 } \\
\text { Chapter }\end{array}$ \\
\hline 1 & General Description & 2 \\
\hline 2 & Principal Design Criteria & $4,12,16$ \\
\hline 3 & Structural Evaluation & $2,3,4$ \\
\hline 4 & Thermal Evaluation & $2,3,4$ \\
\hline 5 & Shielding & $3,4,7$ \\
\hline 6 & Criticality Evaluation & $3,4,6$ \\
\hline 7 & Confinement & $2,3,4,6,7,8,13,16$ \\
\hline 8 & Operating Issues & $11,12,13$ \\
\hline 9 & Acceptance Criteria \& Maintenance & 10,17 \\
\hline 10 & Program & 7,13 \\
\hline 11 & Accident Analyses & 3 \\
\hline 12 & Operating Controls and Limits & 12,17 \\
\hline 13 & Quality Assurance & 17 \\
\hline
\end{tabular}

* Patterned after NRC Regulatory Guide 3.61 . 


\subsubsection{Project/Safety Analysis Scope}

The scope of the SNF subprojects are described in Tables 2-4 and 2-5, and defines the activities to be included in the subproject safety documentation. Table 2-4 provides the K Basins subproject modification scope and Table 2-5 provides the new facilities, MCO, transportation and packaging scope. Appendix A provides an overview of the detailed safety analysis planning process.

The accident analyses of the CSB, CVD, and HCS include numerous common issues and models. Key accident issues include:

- MCO and confinement barrier integrity,

- MCO pressurization,

- Fuel reactivity and corrosion behavior,

- Hydrogen generation/potential for deflagration/detonation,

- Oxygen generation and reactivity with MCO components, and

- Product endstate/ability to seal the MCO (applies for interim storage).

The information needed to close the technical issues, complete model development, and perform the accident analysis is summarized in Table 2-6. This information is discussed in more detail in Section 3.0 and Appendix B.

\subsubsection{Required Safety Documents}

Table 2-7 summarizes the safety documents required for the SNF Project facilities and activities. The required safety documents are discussed in more detail in the sections that follow.

\subsubsection{K Basins SAR/OSR Preparation, Review, and Approval}

$\mathrm{K}$ Basins SAR and OSR amendments and annual updates will be processed in accordance with $\mathrm{K}$ Basins procedures. These updates are discussed in the sections that follow.

1996 Annual Update. The 1996 annual SAR update is to include the changes to the facility since the 1995 annual update, and is being reformatted and content added to the guidance of DOE-STD-3009-94, Preparation Guide for U.S. Department of Energy Nonreactor Nuclear 
Table 2-4. SNF Project K Basins Modifications -

Subproject Scope for Safety Analysis Preparation.

\begin{tabular}{||l|l||}
\hline \multicolumn{1}{|c|}{\begin{tabular}{|l||} 
Program \\
Element
\end{tabular}} & \multicolumn{1}{c||}{ Scope } \\
\hline $\begin{array}{l}\text { K Basins } \\
\text { Modifications } \\
\text { K Basins Essential } \\
\text { Upgrades and Dose } \\
\text { Reduction }\end{array}$ & $\begin{array}{l}\text { Includes design, physical installation, testing, development of training material, } \\
\text { and procedures associated with modifications to the K Basins facility or process } \\
\text { necessary to support the SNF Project activities. }\end{array}$ \\
\hline Fuel Retrieval & $\begin{array}{l}\text { Includes design, physical installation, testing, development of training material, } \\
\text { development of operating procedures and processes, and activities required to } \\
\text { demonstrate readiness of Fuel Retrieval System and related modifications to the } \\
\text { K Basins facility. Work scope includes retrieval of fuel, separation from } \\
\text { canisters, cleaning the fuel, loading the fuel into baskets, and staging loaded } \\
\text { baskets for MCO loading. }\end{array}$ \\
\hline $\begin{array}{l}\text { Water Treatment } \\
\text { System }\end{array}$ & $\begin{array}{l}\text { Includes design, physical installation, testing, development of training material, } \\
\text { development of operating procedures and processes, and activities required to } \\
\text { demonstrate readiness of the Water Treatment System and related modifications } \\
\text { to the K Basins facility. Work scope includes all activities necessary to provide } \\
\text { a decontaminated water supply to the K Basins subprojects and to maintain } \\
\text { water quality. }\end{array}$ \\
\hline $\begin{array}{l}\text { Debris Removal } \\
\text { System }\end{array}$ & $\begin{array}{l}\text { Includes design, physical installation, testing, development of training material, } \\
\text { development of operating procedures and processes, and activities required to } \\
\text { demonstrate readiness of the Debris Removal System and related modifications } \\
\text { to the K Basins facility. Work scope includes retrieval of debris, cleaning of the } \\
\text { debris, and packaging the debris for disposal. }\end{array}$ \\
\hline $\begin{array}{l}\text { Sludge Removal } \\
\text { System }\end{array}$ & $\begin{array}{l}\text { Includes design, physical installation, testing, development of training material, } \\
\text { development of operating procedures and processes, and activities required to } \\
\text { demonstrate readiness of the Sludge Removal System and related modifications } \\
\text { to the K Basins facility. Work scope includes retrieval of sludge, staging the } \\
\text { sludge within the Basins, loading sludge out of the basin into a container for } \\
\text { transfer to TWRS, transportation of sludge to TWRS, and transfer into the } \\
\text { double-shell tank system. }\end{array}$ \\
\hline
\end{tabular}


Table 2-5. SNF Project New Facility, MCO, and Transportation System Subproject Scope for Safety Analysis Preparation (2 Sheets).

\begin{tabular}{|c|c|}
\hline $\begin{array}{l}\text { Program } \\
\text { Element }\end{array}$ & Scope \\
\hline $\begin{array}{l}\text { Cold Vacuum } \\
\text { Drying Facility }\end{array}$ & $\begin{array}{l}\text { Includes design, construction, testing, development of training material, } \\
\text { development of operating procedures and processes, and operations associated } \\
\text { with the CVD; including the structure and equipment, monitoring equipment, } \\
\text { HVAC systems, radiological control systems, and other equipment as required for } \\
\text { fuel drying functions. The SAR will cover siting considerations, facilities, and } \\
\text { equipment to accommodate off-normal conditions. The SAR will also cover } \\
\text { facility D\&D. MCO performance will be covered for vacuum drying. Work scope } \\
\text { includes receipt of the cask and MCO loaded with SNF, dewatering the MCO, } \\
\text { vacuum drying the MCO internals (fuel, sludge, internal components, etc.), } \\
\text { sealing the MCO, and preparing the MCO for transport to the CSB. The MCO } \\
\text { Topical Report will be incorporated by reference. }\end{array}$ \\
\hline $\begin{array}{l}\text { Spent Nuclear } \\
\text { Fuel MCO }\end{array}$ & $\begin{array}{l}\text { Includes design, manufacture, testing, development of training material, } \\
\text { development of operating procedures and processes, and activities required to } \\
\text { demonstrate readiness of the MCOs and related MCO assembly and sealing } \\
\text { activities. The MCO technical baseline and Topical Report will document the } \\
\text { design and environments in which the MCO must function. This topical report } \\
\text { will be referenced by the related facility SARs, as necessary. The MCO safety } \\
\text { basis for transportation is covered in the SARP. }\end{array}$ \\
\hline $\begin{array}{l}\text { MCO Loading, } \\
\text { Cask, and } \\
\text { Transportation } \\
\text { System }\end{array}$ & $\begin{array}{l}\text { Includes design, safety analysis, procurement, testing, development of training } \\
\text { material and operating procedures and processes, activities required to } \\
\text { demonstrate readiness of the Cask and Transportation System to ship fuel on the } \\
\text { Hanford site, and the readiness of the K Basins MCO basket loading and } \\
\text { MCO/cask handling equipment. The SARP will establish the basis for safety of } \\
\text { the transportation packaging and conveyance, for administrative and site access } \\
\text { controls during shipment, for transport of the empty MCO/cask to the K Basins, } \\
\text { closing and sealing the loaded cask, transport of the MCO/cask to the CVD } \\
\text { facility, and transport to and off-loading at the CSB. Modifications to the } \\
\mathrm{K} \text { Basins SAR will document the safety basis for off-loading and placement of the } \\
\text { empty MCO/cask into the basin loadout pit, removal of the loaded MCO/cask } \\
\text { from the K Basins loadout pit, loading the MCO baskets into the MCO, } \\
\text { assembling the MCO, assembling the cask, and placement of the cask onto the } \\
\text { conveyance system. }\end{array}$ \\
\hline
\end{tabular}


Table 2-5. SNF Project New Facility, MCO, and Transportation System Subproject Scope for Safety Analysis Preparation (2 Sheets).

\begin{tabular}{|c|c|}
\hline $\begin{array}{l}\text { Program } \\
\text { Element }\end{array}$ & Scope \\
\hline $\begin{array}{l}\text { Canister Storage } \\
\text { Building }\end{array}$ & $\begin{array}{l}\text { Includes design, construction, testing, development of training material, } \\
\text { development of operating procedures and processes, and operations associated } \\
\text { with the CSB; including the modular storage vault, receiving and load-out } \\
\text { structures and equipment, vault monitoring equipment, cooling systems, HVAC } \\
\text { systems, radiological control systems, and other equipment as required for fuel } \\
\text { storage functions. The SAR will cover siting considerations and } \\
\text { facilities/equipment to accommodate off-normal conditions in an MCO } \\
\text { (e.g., retrieval and repair of an MCO, if necessary). The SAR will also cover } \\
\text { facility D\&D. MCO performance will also be covered for dry staging and storage } \\
\text { conditions. The MCO Topical Report will be incorporated by reference. } \\
\text { The design will consider and accommodate, as necessary, unique functions } \\
\text { associated with the staging of vacuum-dried MCOs prior to hot vacuum } \\
\text { conditioning; including venting of the MCOs to accommodate potential radiolytic } \\
\text { and corrosion gas generation, MCO heat removal, and monitoring and gas } \\
\text { blankets, as necessary, to ensure safe configurations are maintained. The CSB } \\
\text { design may also include the flexibility to store other fuel types or other radioactive } \\
\text { materials and waste forms. }\end{array}$ \\
\hline HCS Facility & $\begin{array}{l}\text { Includes design, construction, testing, development of training material, } \\
\text { development of operating procedures and processes, and operations associated } \\
\text { with the HCS, including the conditioning vault, structures and equipment, } \\
\text { monitoring equipment, HVAC systems, radiological control systems, and other } \\
\text { equipment as required for fuel conditioning functions. The SAR will cover siting } \\
\text { considerations and facilities and equipment to accommodate off-normal } \\
\text { conditions in an MCO container. The SAR will also cover facility D\&D. MCO } \\
\text { performance will also be covered for conditioning. The MCO Topical Report will } \\
\text { be incorporated by reference. }\end{array}$ \\
\hline
\end{tabular}


Table 2-6. Key Models and Technical Input for Accident Analysis.

\begin{tabular}{|c|c|c|c|c|c|}
\hline $\begin{array}{l}\text { Analysis Models/Technical } \\
\text { Inputs }\end{array}$ & Brief Description & $\begin{array}{c}\text { MCO } \\
\text { Topical }\end{array}$ & CVD & CSB & HCS \\
\hline $\begin{array}{l}\text { Fuel lgnition and Reaction } \\
\text { Kinetics: } \\
\text { - Correlation from empirical } \\
\text { data }\end{array}$ & $\begin{array}{l}\text { Fuel reaction rates as a function of: } \\
\text { temperature, humidity, and surface area. } \\
\text { Provides } \mathrm{H}_{2} \text { and } \mathrm{O}_{2} \text { generation }\end{array}$ & $\mathbf{X}$ & $\mathrm{X}$ & $\mathrm{X}$ & $\mathrm{X}$ \\
\hline $\begin{array}{l}\text { MCO Release: } \\
\text { - Thermal-hydraulics flow } \\
\text { model } \\
\text { - Aerosol transport model }\end{array}$ & $\begin{array}{l}\text { Gas and entrained particulates from } \\
\text { MCO as a function of } \mathrm{P}, \mathrm{T}, \mathrm{V} \text {, and } \mathrm{MCO} \\
\text { contents, particulate size distribution. } \\
\text { Provides quantity of gas and particulate } \\
\text { releases. }\end{array}$ & $\mathbf{X}$ & $\mathrm{X}$ & $\mathrm{X}$ & $\mathrm{X}$ \\
\hline $\begin{array}{l}\text { MCO Pressurization: } \\
\text { - Radiolysis rates } \\
\text { - Fuel corrosion reaction } \\
\text { kinetics model } \\
\text { - MCO thermal model }\end{array}$ & $\begin{array}{l}\text { Determines pressure in the MCO from } \\
\text { corrosion and radiolysis based on fuel } \\
\text { and particulate content, water content, } \\
\text { and external conditions. Provides gas } \\
\text { composition and generation rates. }\end{array}$ & $\mathbf{X}$ & $X$ & $\mathrm{X}$ & $\mathrm{X}$ \\
\hline $\begin{array}{l}\mathrm{H}_{2} \text { detonation and } \\
\text { deflagration: } \\
\text { - Radiolysis rates } \\
\text { - Fuel corrosion reaction } \\
\text { kinetics model } \\
\text { - Air ingress model } \\
\text { - } \mathrm{H}_{2} / \mathrm{O}_{2} \text { reaction regimes } \\
\text { - Oxygen } \\
\text { depletion/gettering model }\end{array}$ & $\begin{array}{l}\text { Determines } \mathrm{O}_{2} \cdot \mathrm{H}_{2} \text { ratio at which } \\
\text { detonation or deflagration will occur and } \\
\text { the transient behavior as a function of } \\
\text { confining geometry. } \\
\text { Evaluates air ingress and internal MCO } \\
\mathrm{O}_{2} \text { generation/gettering phenomena. }\end{array}$ & $\mathrm{X}$ & $\mathrm{X}$ & $\mathrm{X}$ & $\mathrm{X}$ \\
\hline
\end{tabular}


Table 2-7. Safety Documents Required for the SNF Project.

\begin{tabular}{|c|c|c|c|c|c|c|c|c|}
\hline Program Element & $\begin{array}{c}\text { FRD } \\
\text { or } \\
\text { FDC }\end{array}$ & PSE $^{1}$ & $\begin{array}{c}\text { USQ } \\
\text { Reviews }\end{array}$ & $\mathbf{S} / \mathbf{R W D}^{2 \mathbf{3}}$ & $\begin{array}{l}\text { SAR, } \\
\text { OSR, } \\
\text { TSR }^{3} \\
\end{array}$ & $\begin{array}{l}\text { MCO } \\
\text { Topical } \\
\text { Report } \\
\end{array}$ & SARP & $\begin{array}{l}\text { ORR, as } \\
\text { needed }^{3}\end{array}$ \\
\hline $\begin{array}{l}\text { K Basins } \\
\text { Modifications }\end{array}$ & & & $\checkmark$ & & $\mathfrak{J}^{4}$ & $\checkmark$ & & \\
\hline $\begin{array}{l}\text { Fuel Retrieval } \\
\text { System }\end{array}$ & $\checkmark$ & $\checkmark$ & $\checkmark$ & $\mathfrak{d}^{5}$ & $\sigma^{4}$ & & & $\checkmark$ \\
\hline $\begin{array}{l}\text { Water Treatment } \\
\text { System }\end{array}$ & $\checkmark$ & $\checkmark$ & $\checkmark$ & $s^{s}$ & $\Omega^{4}$ & & $\rho^{\circ}$ & $\checkmark$ \\
\hline $\begin{array}{l}\text { Debris Removal } \\
\text { System }\end{array}$ & $\checkmark$ & & $\checkmark$ & & $\boldsymbol{f}^{4}$ & & $\rho^{7}$ & $\checkmark$ \\
\hline $\begin{array}{l}\text { Sludge Removal } \\
\text { System }^{8}\end{array}$ & $\checkmark$ & $\checkmark$ & $\checkmark$ & $\rho^{s}$ & $f^{4}$ & & $\rho^{9}$ & $\checkmark$ \\
\hline $\begin{array}{l}\text { Cold Vacuum } \\
\text { Drying }\end{array}$ & $\checkmark$ & $\checkmark$ & & $\checkmark$ & $J^{10}$ & $\checkmark$ & $J^{\prime \prime}$ & $d$ \\
\hline $\begin{array}{l}\text { Multi-Canister } \\
\text { Overpacks }\end{array}$ & $\checkmark$ & & $J^{12}$ & & $\sqrt{4.10}$ & $d$ & $\sigma^{13}$ & \\
\hline $\begin{array}{l}\text { Cask and } \\
\text { Transportation } \\
\text { System }\end{array}$ & $9^{1 k}$ & & $J^{12}$ & & $\gamma^{4.10}$ & $\alpha$ & $d$ & $\checkmark$ \\
\hline $\begin{array}{l}\text { Canister Storage } \\
\text { Building }\end{array}$ & $\checkmark$ & $\checkmark$ & & $s$ & $\sqrt{10}^{10}$ & $\checkmark$ & & $\checkmark$ \\
\hline $\begin{array}{l}\text { Hot Conditioning } \\
\text { System }\end{array}$ & $\checkmark$ & $\checkmark$ & & $\checkmark$ & $\sigma^{10}$ & $\checkmark$ & & $\checkmark$ \\
\hline
\end{tabular}

' Including a hazard analysis and hazard categorization evaluation.

${ }^{2}$ Update S/RIDs, as needed.

${ }^{3}$ Included in the facility authorization basis.

${ }^{4}$ Amendment(s) to K Basins SAR/OSR, as needed.

${ }^{5} \mathrm{~K}$ Basins S/RID update, as necessary.

${ }^{6}$ SARP for removal of water treatment filters, etc., as needed.

${ }^{7}$ SARP for removal of debris, as needed.

${ }^{8}$ The SRS scope includes amendments to the TWRS safety documentation.

${ }^{9}$ SARP for removal of sludge, as needed.

${ }^{10} \mathrm{MCO} / \mathrm{SARP}$ impacts will be addressed in the new facility SAR/TSR, as appropriate.

"SARP for removal of contaminated water, as needed.

${ }^{12}$ USQ evaluation will be performed as part of the integrated K Basins SAR amendment development for actions in the Basins.

${ }^{13}$ MCO impacts will be addressed in the SARP.

${ }^{14}$ Packaging Design Criteria. 
Facility Safety Analysis Reports. The intent is to have a SAR compliant with DOE Order 5480.23, Safety Analysis Reports. Updates are to include basin water cleanup systems changes, crane USQ closure material, deletion of specific sections addressing encapsulation and hanging fuel. Content additions are event trees to support event frequencies, expanded system descriptions, and discussion of how key requirements are implemented and human factors are addressed.

The OSRs are to be updated, reformatted, and content changed or added to be in compliance with DOE Order 5480.22, Technical Safety Requirements, and are to be reissued as a TSR document.

The SAR and TSR, when approved and implemented, provide the basis for USQ evaluations and updates to support Integrated Process Strategy modifications to the K Basins Facility and to accommodate interfaces or interactions with CVD, CSB, and/or MCO requirements.

1997 Special Update. The purpose of the 1997 SAR/TSR amendment submittal is to include the FRS, the IWTS, the MCO Topical Report, loading the fuel baskets into the $\mathrm{MCO} /$ Cask, handling the $\mathrm{MCO} /$ Cask, the $\mathrm{MCO} /$ Cask transport within the $105 \mathrm{~K}$ fence, the $\mathrm{MCO}$ Cask/SARP interface, and the CVD interface/interaction issues into the $\mathrm{K}$ Basins safety authorization basis.

The SAR and TSR, when approved and implemented, provide the basis for USQ evaluations and updating to support additional IPS modifications to the $\mathrm{K}$ Basins facility and the start of fuel removal operations from the Basins.

1998 Special Update. The purpose of the 1998 submittal is to include the Sludge Removal subproject system and all other annual update issues into the $\mathrm{K}$ Basins safety authorization basis.

\subsubsection{SAR/TSR Preparation, Review, and Approval for New Facilities}

The following principles will be applied to streamline the SAR/TSR preparation, review, and approval process:

- The scope, format, and content of the SAR/TSR will be approved by the management of the organization performing the analysis, appropriate Contractor management and oversight organizations, and the DOE approval authority.

- The safety analysis preparation and review process is an ongoing, iterative effort between the SAR/TSR preparation staff; the design, construction, and operations staffs; and the staff responsible for review and oversight. The design organization for each project (i.e., Fluor Daniel is the architect engineer for the CSB) will have the 
responsibility to produce the initial drafts of the design-related chapters (Chapters 2 and 4) (see Table 2-8). These chapters will include identification of all necessary codes and standards used in the design and construction of the facility.

- The SARs may be prepared in phases (to support preparation of new facility operating procedures, operator training, and the $\mathrm{ORR}$, and for producing the completed SAR document) or as partial chapters of the SAR (to support construction activities) and reviewed in-process by DOE reviewers and the IRP. The RRT will be requested to review the SAR and oversight will be provided by DOE-EH. Review feedback will be provided to the Project throughout the process. The TSR preparation and review will be included in the appropriate SAR phase activity. Specifics of the phased and partial SAR chapters review processes are defined in the ISMP. (See the specific facility sections, 2.5 .8 .1 to 2.5 .8 .3 , for details.)

Table 2-8. SAR Chapters from DOE-STD-3009-94.

\begin{tabular}{|c|l|c|l||}
\hline Chapter & \multicolumn{1}{|c|}{ Content Description } & Chapter & \multicolumn{1}{|c|}{ Content Description } \\
\hline 0.0 & Executive Summary & 9.0 & $\begin{array}{l}\text { Radioactive and Hazardous Waste } \\
\text { Management }\end{array}$ \\
\hline 1.0 & Site Characteristics & 10.0 & $\begin{array}{l}\text { Initial Testing, In Service Surveillance, } \\
\text { and Maintenance }\end{array}$ \\
\hline 2.0 & Facility Description & 11.0 & Operational Safety \\
\hline 3.0 & Hazard and Accident Analysis & 12.0 & Procedures and Training \\
\hline 4.0 & $\begin{array}{l}\text { Safety Structures, Systems, and } \\
\text { Components }\end{array}$ & 13.0 & Human Factors \\
\hline 5.0 & $\begin{array}{l}\text { Derivation of Technical Safety } \\
\text { Requirements }\end{array}$ & 14.0 & Quality Assurance \\
\hline 6.0 & $\begin{array}{l}\text { Prevention of Inadvertent } \\
\text { Criticality }\end{array}$ & 15.0 & Emergency Preparedness Program \\
\hline 7.0 & Radiation Protection & 16.0 & $\begin{array}{l}\text { Provisions for Decontamination and } \\
\text { Decommissioning* }\end{array}$ \\
\hline 8.0 & Hazardous Material Protection & 17.0 & $\begin{array}{l}\text { Management, Organization, and } \\
\text { Institutional Safety Provisions }\end{array}$ \\
\hline
\end{tabular}

* Provisions for D\&D are discussed per the requirements of DOE Order 5480.23. Actual D\&D will be performed by other Hanford projects, not the SNF Project. 
- DOE's review of the SARs/TSRs will be documented in an SER or an equivalent document that will be scheduled and completed in a way that supports the IPS milestones for removal of fuel from the K Basins (WHC 1995b). Planning calls for the facility SAR/TSR to be reviewed by a dedicated DOE team, that will prepare the SER.

An independent review process will be implemented to ensure an acceptable level of worker safety, public health and safety, and protection of the environment. Independent reviews will be provided by DOE EH-O staff and the IRP. The IRP will review the SNF Project safety analysis documentation and verify that the MCO, CVD, CSB, and HCS meet DOE's policy with respect to demonstrating NRC nuclear safety equivalency. DOE EH-O will oversee the process, as necessary. The review process will also provide for appropriate public review and input to the safety authorization process as contained in the Spent Nuclear Fuel Project Tribal, Stakeholder, and Regulatory Communication and Participation Strategy (WHC 1995i).

The SNF Project plans to develop a single SAR for each of the new facilities (CVD, CSB, and HCS facilities), which combines the preliminary and final SAR development steps as allowed by DOE Order 5480.23, Nuclear Safety Analysis Reports. ${ }^{3}$ The single SAR will be developed in distinct phases that represent logical ties to the progress of the facility design, construction, and facility start-up activities. ${ }^{4}$ The development, review, and approval of facility SARs in phases is authorized in DOE Order 5480.23. The single SAR will be prepared in accordance with DOE Order 5480.23, Nuclear Safety Analysis Reports, following the content and format guidelines of the DOE-STD-3009-94, Preparation Guide for U.S. Department of Energy Nonreactor Nuclear Facility Safety Analysis Reports (chapter contents are shown in Table 2-8), and supplemented with the applicable requirements of 10 CFR Part 72.24 and NRC Regulatory Guides (see Section 2.4.2).

The use of the single SAR produced in phases is needed in order to support the expedited schedule for removing the SNF from the K Basins, which are located near the Columbia River. Typically, a Preliminary Safety Analysis Report (PSAR) is developed while the complete facility design is being finalized. This document is reviewed and approved by DOE and is the authorization basis for the construction of a facility. While the facility is being constructed, the Final Safety Analysis Report is prepared and reviewed and approved by DOE. This two-step process does not support the accelerated SNF Project schedule.

The expedited schedule being used by the project supports risk reduction by using a phased-construction start based on design package completion and not on completion of the

${ }^{3}$ DOE Order 5480.23 allows (with DOE approval) the preparation of a single SAR for facilities, in lieu of preparing separate preliminary and final SARs. The SNF Project obtained DOE direction to implement the single SAR approach in the memorandum from J. E. Lytle to T. P. Grumbly in March 1995 (Lytle 1995).

${ }^{4}$ DOE Order 5480.23, Paragraph 9.a.(3) allows (with DOE approval) the SARs to be prepared and submitted in stages. The SNF Project obtained DOE direction to implement staged SARs in a memorandum from J. E. Lytle to T. P. Grumbly in March 1995 (Lytle 1995). 
facility design. This phased concept allows construction to start (at some program risk) as much as six to eight months early for the CSB, as compared to the construction start based on a PSARauthorized construction. The CVD facility construction will start as much as six months early. These schedule savings correspond to a savings of $\$ 30$ to $\$ 40$ million for the SNF Project. An early start of construction for the HCS facility has an additional savings based on using the same civil/structural contractor as that of the CSB. Without this ability, the bid process to acquire another contractor would add cost to the overall project.

The programmatic risks associated with the phased construction authorization offset larger safety risks associated with delays in transfer of the SNF away from the Columbia River to the CSB. However, schedule delays caused by potential rework of facility designs to accommodate changes from the phased SAR submittals to the complete SAR do represent actual safety risks caused by delays in transferring the SNF.

Partial SAR chapters submitted for approval in support of facility construction activities are prepared following the logic presented in Figure 2-3. These partial SAR chapters are placed under configuration control in accordance with the requirements of the SNF Project Configuration Management Plan (WHC 1995j), until the full SAR chapters are approved.

Other safety documents that support preparation of the SAR documentation include the PSE and the FHA, preparation of an evaluation of Natural Phenomena Hazards, preparation of the CSER, and preparation of the TSR. These documents are described in Section 2.5.4.

The phased SAR documentation will receive reviews by the appropriate SNF Project disciplines. Following preparation and peer review, the phased SAR submittals will receive a functional review within the Contractor organization in accordance with the requirements defined in the SNF Project Configuration Management Plan (WHC 1995j) and WHC-CM-3-5, Document Control and Records Management Manual, Section 12.7, "Approval of Environmental, Safety, and Quality Affecting Documents" (WHC 1994c). The functional review involves a multi-disciplined review by responsible project staff, appropriate technical experts, and independent oversight organizations within the Contractor organization to validate the technical adequacy of the document. Review comments received at the Contractor functional level and from others will be formally dispositioned using Review Comment Record forms or equivalent documentation. Following the Contractor functional review, the phased SAR documents will be forwarded to the Safety and Environmental Advisory Council (SEAC) for review. Following receipt of the comments from the SEAC review, the phased SAR documentation will be sent to DOE for review and approval. During the phased SAR preparation process, cognizant reviewers will assist the SNF Project RI\&PI personnel in coordinating the reviews and comment resolution of each chapter evaluation to which they are assigned responsibility. Figure 2-4 depicts the review and approval process that is planned for the phased SAR submittals. 

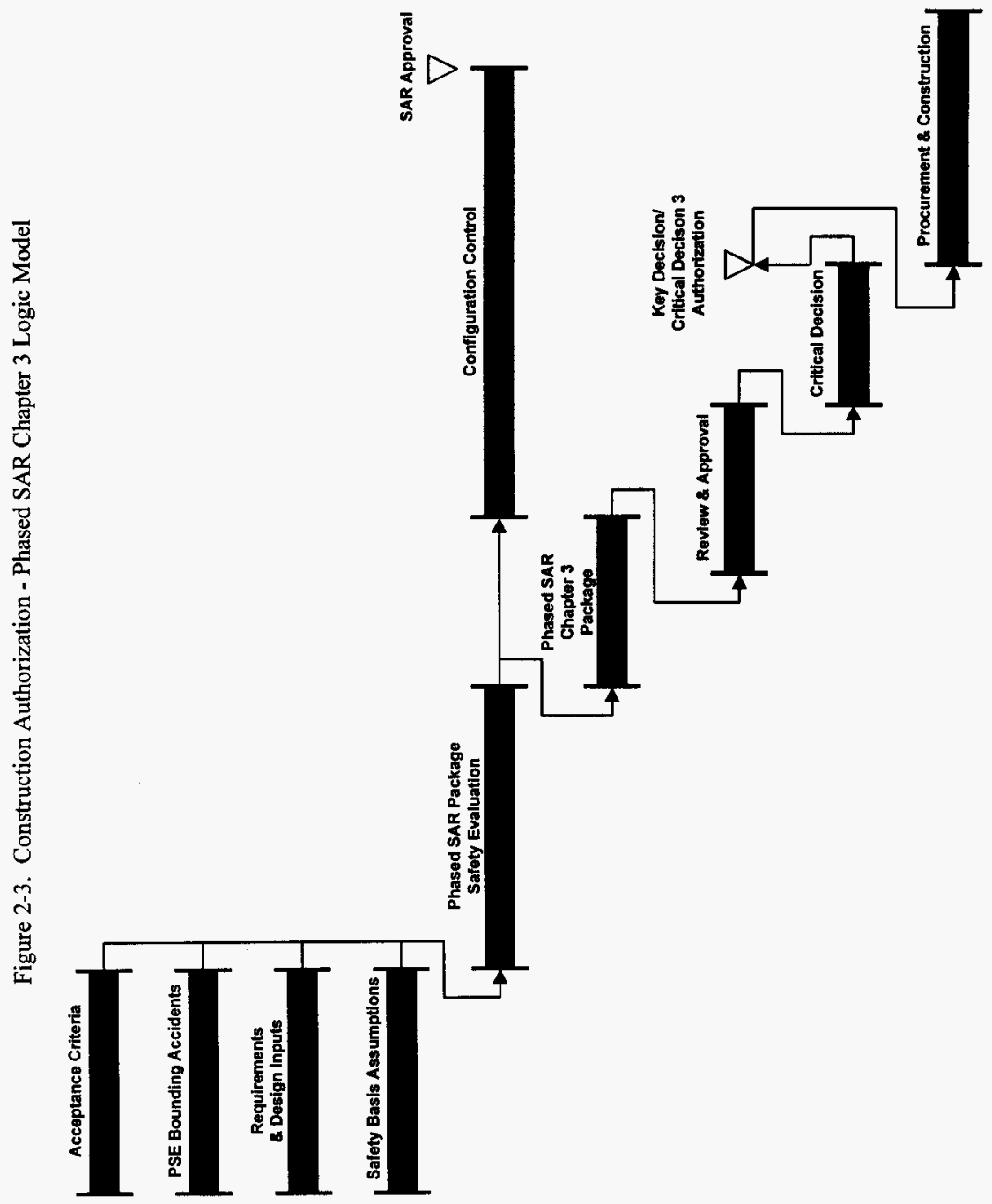
Figure 2-4. Phased SAR Review and Approval Process for SNF Project New Facilities.*

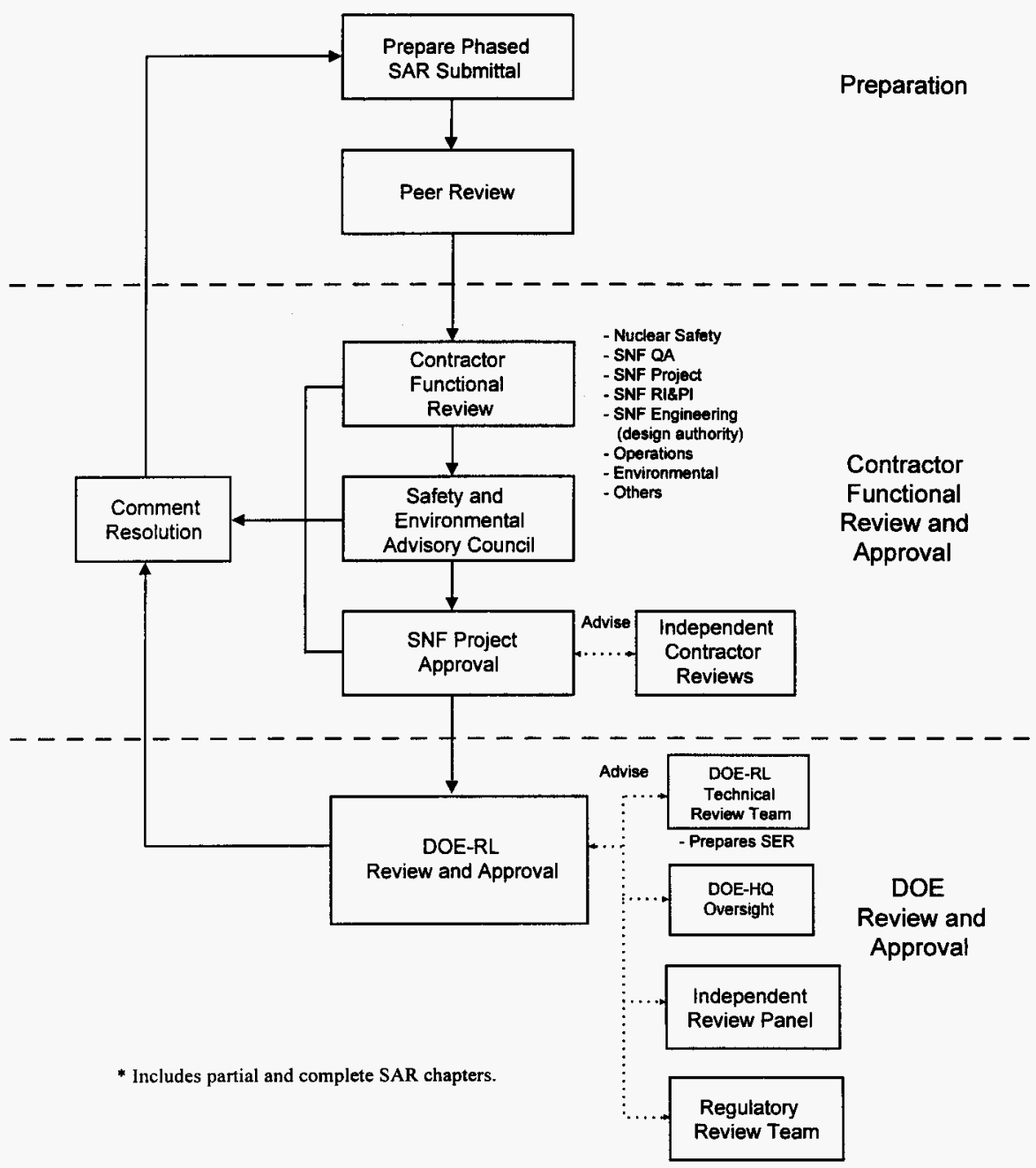


The SARs are being transmitted to DOE in phases to accommodate an accelerated review process and ultimate approval. Not all issues will be finally resolved at the time of initial chapter transmission. All issues must be satisfactorily resolved prior to the final DOE approval of the complete SAR and authorization to operate the facility or activity. Examples that may fall in this category include: characterization of sludge drying characteristics, and benchmarking rate confirmation for irradiated $\mathrm{N}$ Reactor fuel and oxygen reactions. These uncertainties will be identified in the appropriate SAR transmittals along with the information currently known, the interim technical justification for use of the assumption in the analysis, the task scope for resolution, and the schedule for resolution. All assumptions will be tracked, formally resolved, and documented prior to requesting final DOE operations authorization.

Assumptions used for phased SAR submittals that require subsequent verification will, to the degree practical, be conservative in order to minimize the program risks of characterization or test data failing to support the assumptions. Risk assessment and contingency planning will be used (where appropriate) for those tasks with inadequate information to proceed.

Each section contained in a phased SAR submittal will receive DOE approval, once all questions and review comments are resolved. DOE will consider the level of review required for approval of subsequent phased SAR submittals. Additional reviews of the same SAR chapter will focus on changes to approved submittals. Review and approval of the completed SARs will focus on verification of assumptions and changes in approved chapters. These reviews may be minimal depending on the similarity to previous submittals. It is anticipated that this process will aid in expediting the approval of SNF Project safety documentation.

DOE review of the SNF CSB SAR should carry over to subsequent SARs developed for the CVD and HCS, with the exception of specially identified facility-specific modifications. For example, submittals of generic SAR chapters, such as Quality Assurance (Chapter 14) and Emergency Preparedness (Chapter 15), for the CVD and HCS facilities should receive expedited approval because they will have minimal or no changes from the approved CSB SAR chapters. Other SAR chapters such as Radiation Protection (Chapter 7), Hazardous Material Protection (Chapter 8), and Management, Organization, and Institutional Safety Provisions (Chapter 17), should also receive expedited approval because they will implement only facility-specific changes to the approved CSB SAR chapters.

Once all of the chapters are completed, the entire SAR will be reviewed by the preparer organization and by the SNF Project organization to ensure it is complete. The focus of this review is on changes to approved chapters and on new chapters, as appropriate. Figure 2-5 depicts the review and approval process that is planned for the complete SAR. 
Figure 2-5. SAR Review and Approval Process for SNF Project New Facilites.

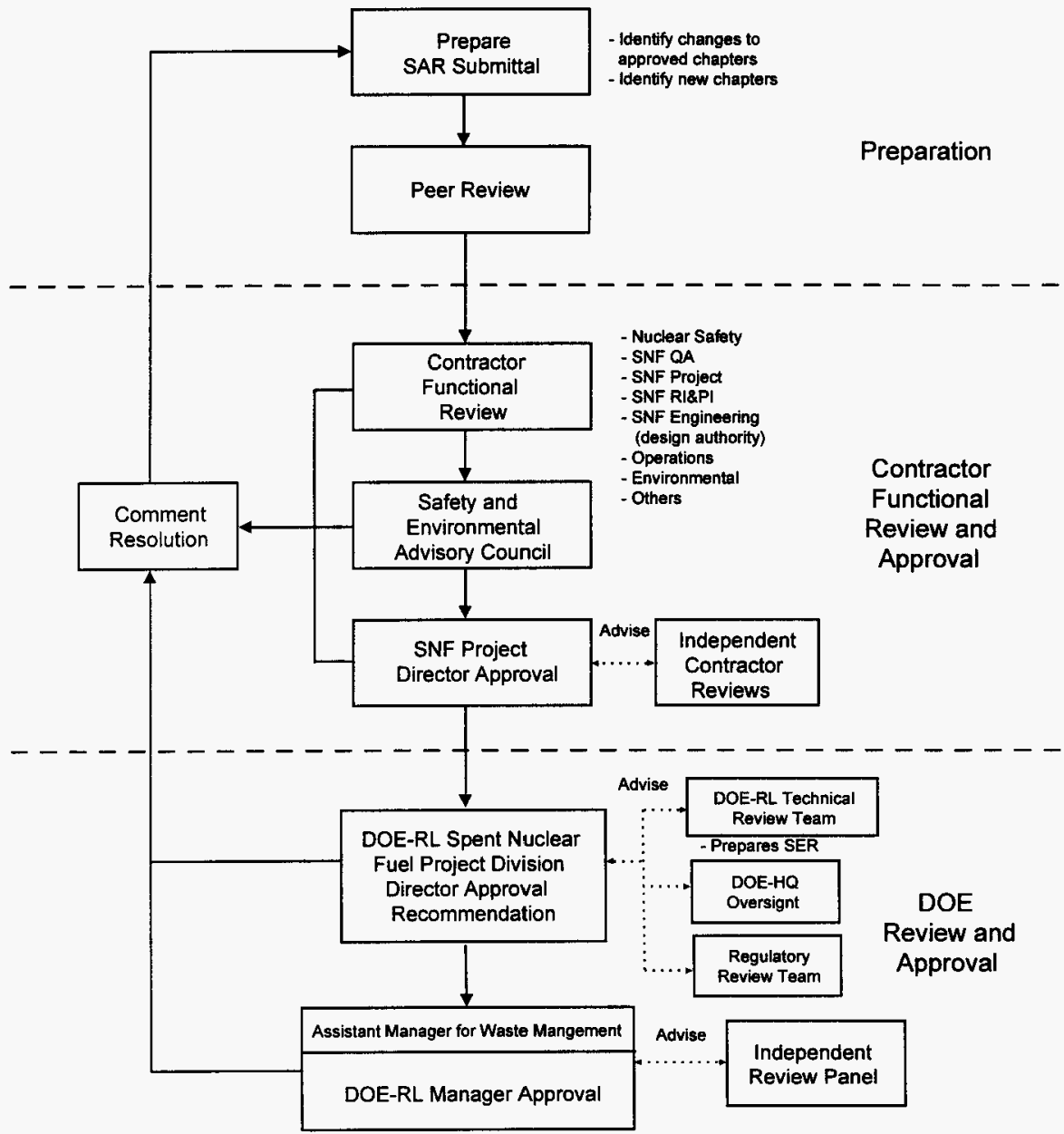


Formal comments for the complete SAR will be dispositioned and the SAR chapters corrected as required. Review meetings will be held with the reviewers to resolve difficult issues, as required. The SAR will be updated as appropriate until the final review and approval. Upon completion of the functional reviews, the SAR will be approved by the Contractor and then forwarded to DOE for review and approval. The DOE review process will be handled as discussed above, with formal comment disposition.

The Contractor and DOE SAR review process must be carefully managed to ensure thorough reviews of the phased SAR submittals. Partial reviews of the phased submittals with the expectation or plan to perform the "real" review of the completed SAR will cause major SNF Project delays. Once SAR chapters are approved, only changes will be subject to additional review and approval.

For the SNF Project, the DOE SNF Project Office will have the responsibility and authority for review and coordination of the safety documentation approval (Grumbly 1994). The Project Office staff will obtain the necessary internal DOE reviews. DOE will document their review in an SER for each SAR. A final SER will be prepared by DOE-RL for each SAR and submitted to the Manager of DOE-RL with the appropriate recommendations for SAR approval. The DOE-RL manager has authorization approval authority for SNF Project facilities operation.

While review of the SARs by the DNFSB is not required, the SNF Project recognizes that the DNFSB has an interest in the expedited removal of the K Basins fuel to safer storage conditions. Consequently, routine briefings of the DNFSB staff on progress, including the results of the safety analyses and evaluation, is planned as part of the normal SNF Project activities. This on-going effort to keep the DNFSB informed will provide a means to identify and resolve DNFSB comments and concerns relative to project safety issues in a timely manner.

The phases, including SAR chapters and other documentation that will be included in each phase, are each unique to their facility. However, each facility will have an initial phase that will be submitted to support the early start of construction. This construction support package contains partial SAR chapters selected from DOE-STD-3009-94, Preparation Guide for U.S. Department of Energy Nonreactor Nuclear Facility Safety Analysis Reports, and relates to construction, the management of construction, and the risks associated with the facility portion that is to be constructed using the SAR phase. This package consists of portions of Chapters 1,2 , $3,4,6,14,16$, and 17 (see Table 2-8). Other phases depend on the construction sequence, facility mission, and facility relationship to other SNF Project facilities. Before each of these construction-related phases are submitted to DOE for review, a letter defining the SAR chapter content to be used to support the construction phase will be produced by the Contractor and approved by DOE-RL. This letter of agreement will include the justification for the DOE-STD-3009-94 content selected. See Sections 2.5.8.1, 2.5.8.2, and 2.5.8.3 for additional information on phased SAR development for the CSB, CVD, and HCS subprojects.

All of the facility SARs will reference an MCO Topical Report, which will contain the design and standard accident analysis details related to the MCO. Specific accident analyses that 
are unique to the facility will be contained in the facility SAR text. See Sections 2.5 .4 and 2.5.9 for more information on the MCO Topical Report.

The required regulatory reviews and approvals for DOE and the Contractor are depicted in Tables 2-9 and 2-10, respectively.

\subsubsection{Canister Storage Building}

Figure 2-6 includes a diagrammatic schedule of the phased SAR activities planned for the CSB. The major elements in the CSB design and construction phases are included to illustrate their relationship to the phased SAR process. Relationships are indicated with tie lines from the construction activity to the specific SAR phase. Input from the MCO Topical Report is also shown on the schedule. The completed phased SAR chapters will contain information on the MCO, as required for the specific chapter, until the MCO Topical Report is issued. Once the MCO Topical Report is issued, the completed SAR will reference the Topical Report, and detailed information on the MCO will be deleted from the SAR.

The initial CSB phased SAR submittal supports initiation of construction of the CSB substructure. This package contains the construction-related sections of SAR chapters 1, 2, 3, 4,6, 14,16 , and 17 .

The second CSB phased SAR submittal supports authorization of construction for the CSB operating deck, storage tubes, receiving crane, and MCO Handling Machine. This submittal includes the FHA and completed Chapters 1 and 6 . The third CSB phased SAR submittal supports authorization of construction for the CSB superstructure and remaining operating systems. This package includes a partial SAR Chapter 4 . The remaining series of submittals are completed SAR chapters, leading to the submittal of the complete SAR to DOE for approval. These submittals support development of the facility operating procedures, personnel training, and initiation of the ORR.

The phases, including SAR chapters and other documentation that will be included in each phase, are presented in Table 2-11.

\subsubsection{Cold Vacuum Drying Facility}

The SNF Project plans to develop safety analysis documentation for the CVD facility using a phased document preparation and review approach as allowed by the direction provided in DOE Order 5480.23. ${ }^{5}$ The SAR development phases are intended to coincide with the progress

${ }^{3}$ DOE Order 5480.23, Paragraph 9.a.(3) allows (with DOE approval) the SARs to be prepared and submitted in stages. The SNF Project obtained DOE direction to implement staged SARs in a memorandum from J. E. Lytle to T. P. Grumbly in March 1995 (Lytle 1995). 
Table 2-9. SNF Program New Facility Safety Documentation Task Responsibility Matrix. ${ }^{1}$

\begin{tabular}{|c|c|c|c|c|c|c|c|c|}
\hline \multirow{3}{*}{$\begin{array}{c}\text { Regulatory Program } \\
\text { Task }\end{array}$} & \multicolumn{7}{|c|}{ Responsibility } & \multirow[b]{3}{*}{ Vehicle } \\
\hline & \multirow[b]{2}{*}{ Contractor } & \multirow[b]{2}{*}{ RRT $^{2}$} & \multicolumn{5}{|c|}{ DOE } & \\
\hline & & & SNFPO & $\mathbf{R L}$ & $\mathbf{E M}$ & EH & IRP & \\
\hline DOE's Regulatory Policy & & & $\mathrm{C}$ & A & $\mathrm{C}$ & $\mathrm{C}$ & & Action Memorandum \\
\hline Regulatory Requirements & $\mathbf{P}$ & $\mathrm{R}$ & A & A & $\mathrm{C}$ & $\mathrm{C}, \mathrm{O}$ & $\mathrm{C}$ & $\begin{array}{l}\text { Requirements identification process. } \\
\text { Regulatory Requirements } \\
\text { Document, approved and controlled. }\end{array}$ \\
\hline $\begin{array}{l}\text { Prepare and Issue SAR } \\
\text { and TSRs }\end{array}$ & $\mathrm{P}$ & & $\mathrm{R}, \mathrm{D}$ & & & & & SAR/TSR transmittal \\
\hline $\begin{array}{l}\text { SAR/TSR Technical } \\
\text { Review }\end{array}$ & $\mathbf{R}$ & $\mathbf{R}$ & $\mathbf{R}$ & $\mathrm{R}^{3}$ & & $\mathrm{O}$ & $\mathbf{R}$ & $\begin{array}{l}\text { Report documenting review process, } \\
\text { findings, and resolution }\end{array}$ \\
\hline SAR/TSR Approval & $A^{4}$ & & $\mathrm{C}$ & $\mathbf{A}$ & & & $\mathrm{C}$ & Approval Memorandum \\
\hline $\begin{array}{l}\text { Operational Readiness } \\
\text { Review and Authorization } \\
\text { to Operate }\end{array}$ & $\mathrm{S}$ & & $\mathrm{C}$ & $\mathrm{AO}$ & & C & & $\begin{array}{l}\text { Action Memorandum based on } \\
\text { Readiness Review }\end{array}$ \\
\hline $\begin{array}{l}\text { Public and Interested } \\
\text { Group Review }\end{array}$ & $\mathbf{S}$ & & D & & & & & $\begin{array}{l}\text { SNF Project Office (SNFPO) } \\
\text { Communication Strategy }\end{array}$ \\
\hline $\begin{array}{l}\text { Inspection and } \\
\text { Enforcement }\end{array}$ & $\mathbf{S}$ & & $\mathbf{S}$ & $\mathrm{S}$ & & D & & Inspection Plan \\
\hline
\end{tabular}

$\begin{array}{lll}\text { Legend: } & \mathrm{P}=\text { Prepare } & \mathrm{AO}=\text { Authoriz } \\ & \mathrm{R}=\text { Review } & \mathrm{S}=\text { Support } \\ \mathrm{A}=\text { Approve } & \mathrm{D}=\text { Direct } \\ \mathrm{C}=\text { Concur } & \mathrm{O}=\text { Oversight }\end{array}$

1 A safety documentation approval matrix is shown in more detail in Table 2-10.

2 The Regulatory Requirements Team is comprised of DOE-HQ, DOE-RL, Contractor and other vendor personnel, as needed, who are familiar with the NRC and DOE regulatory requirements.

3 The DOE-RL technical review team will be convened by DOE-RL's Office of Environment, Safety, and Health (RL-ESH) and will include technical specialists in the field of

4 facility nuclear safety, from EH-T and other organizations as appropriate. DOE's review of the SAR and TSRs will be documented in a formal Safety Evaluation Report.

4 Approve for submittal to DOE. 
Table 2-10. SNF Program New Facility Safety Documentation Approval Matrix. ${ }^{1,2}$

\begin{tabular}{|c|c|c|c|c|c|}
\hline \multirow[b]{2}{*}{ Contractor Approvals } & \multirow[b]{2}{*}{$\begin{array}{c}\text { Hazard } \\
\text { Categorization }\end{array}$} & \multirow[b]{2}{*}{ PSE } & \multirow{2}{*}{$\begin{array}{l}\text { MCO } \\
\text { Topical } \\
\text { Report }\end{array}$} & \multicolumn{2}{|c|}{ SAR $^{3}$} \\
\hline & & & & $\begin{array}{l}\text { Construction } \\
\text { Authorization }\end{array}$ & $\begin{array}{c}\text { Operating } \\
\text { Authorization }\end{array}$ \\
\hline Preparer & $\checkmark$ & $\checkmark$ & $\checkmark$ & $\checkmark$ & $\checkmark$ \\
\hline Peer Reviewer & $\checkmark$ & $\checkmark$ & $\checkmark$ & $\checkmark$ & $\checkmark$ \\
\hline SNF Design Authorities & $\checkmark$ & $\checkmark$ & $\checkmark$ & $\checkmark$ & $\checkmark$ \\
\hline SNF Engineering Manager & $\checkmark$ & $\checkmark$ & $\checkmark$ & $\checkmark$ & $\checkmark$ \\
\hline SNF Project Organization ${ }^{4}$ & $\checkmark$ & $\checkmark$ & $\checkmark$ & $\checkmark$ & $\checkmark$ \\
\hline $\begin{array}{l}\text { K Basins Standards and } \\
\text { Requirements }\end{array}$ & & & $\checkmark$ & & $\sigma^{5}$ \\
\hline Fuel Handling Operations & & & & & $s^{s}$ \\
\hline SNF Project QA Manager & $\checkmark$ & $\checkmark$ & $\checkmark$ & $\checkmark$ & $\checkmark$ \\
\hline $\begin{array}{l}\text { SNF Regulatory Integration and } \\
\text { Public Involvement }\end{array}$ & $\checkmark$ & $\checkmark$ & $\checkmark$ & $\checkmark$ & $\checkmark$ \\
\hline SNF Nuclear Safety Engineer & $\checkmark$ & $\checkmark$ & $\checkmark$ & $\checkmark$ & $\checkmark$ \\
\hline $\begin{array}{l}\text { Cognizant Nuclear Safety } \\
\text { Manager }\end{array}$ & $\checkmark$ & $\checkmark$ & $\checkmark$ & $\checkmark$ & $\checkmark$ \\
\hline $\begin{array}{l}\text { Manager, Criticality Safety (if } \\
\text { criticality analysis required) }\end{array}$ & & & $\checkmark$ & $\checkmark$ & $\checkmark$ \\
\hline $\begin{array}{l}\text { Safety and Environmental } \\
\text { Advisory Council }\end{array}$ & $\checkmark$ & & $\checkmark$ & $\checkmark$ & $\checkmark$ \\
\hline Director, SNF Project & $\checkmark$ & $\checkmark$ & $\checkmark$ & $d$ & $\checkmark$ \\
\hline \multicolumn{6}{|l|}{ DOE-RL Approvals } \\
\hline DOE-RL & $\checkmark$ & & $\checkmark$ & $\checkmark$ & $\checkmark$ \\
\hline
\end{tabular}

Conforms with WHC-CM-3-5, Chapter 12.7 requirements (WHC 1994c)

${ }^{2} \mathrm{~K}$ Basins documentation based on existing $\mathrm{K}$ Basins procedures.

${ }^{3}$ SAR approval process applicable to the CSB, CVD, and HCS facilities.

${ }^{4} \mathrm{~K}$ Basins Project Manager or SNF Project Manager

${ }^{5}$ Final SAR/TSR approval only 


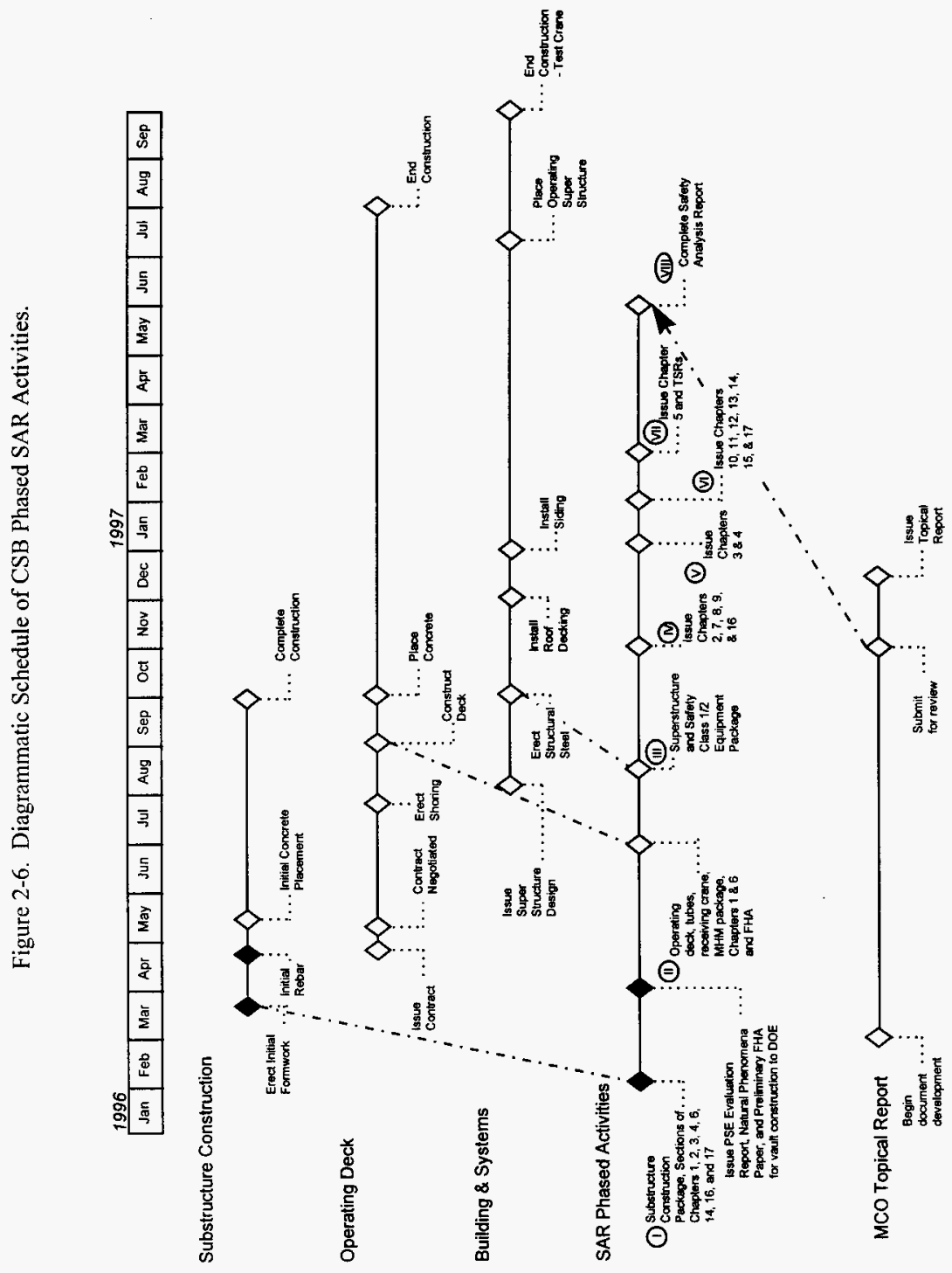


Table 2-11. Canister Storage Building Phased Safety Analysis Report Approach.

\begin{tabular}{|c|c|}
\hline Submittals & Contents \\
\hline I & $\begin{array}{l}\text { Substructure Construction Support Phase, Sections of Chapters: } \\
\text { 1.0 - Site Characterization (partial) } \\
\text { 2.0 - Facility Description (partial) } \\
\text { 3.0 - Hazards and Accident Analysis (partial) } \\
\text { 4.0 - Safety Structures, Systems, and Components (partial) } \\
\text { 6.0 - Prevention of Inadvertent Criticality (partial) } \\
\text { 14.0- Quality Assurance (partial) } \\
\text { 16.0 - Provisions for Decontamination and Decommissioning (partial) } \\
\text { 17.0 - Management, Organization, and Institutional Safety Provisions (partial) }\end{array}$ \\
\hline II & $\begin{array}{l}\text { Operating Deck Construction Support Phase - similar to Submittal I } \\
\text { 1.0 - Site Characteristics (complete) } \\
\text { 2.0 - Facility Description (partial) } \\
\text { 3.0 - Hazards and Accident Analysis (partial) } \\
\text { 4.0 - Safety Structures, Systems, and Components (partial) } \\
\text { 6.0 - Prevention of Inadvertent Criticality (complete) } \\
\text { 16.0 - Provisions for Decontamination and Decommissioning (partial) } \\
\text { Fire Hazards Analysis (complete) }\end{array}$ \\
\hline III & $\begin{array}{l}\text { Superstructure Building and Systems - Similar to Submittal l } \\
\text { 2.0 - Facility Description (partial) } \\
\text { 3.0 - Hazards and Accident Analysis (partial) } \\
\text { 4.0 - Safety Structures, Systems, and Components (partial) } \\
\text { 16.0 - Provisions for Decontamination and Decommissioning (partial) }\end{array}$ \\
\hline IV & $\begin{array}{l}\text { 2.0 - Facility Description (complete) } \\
\text { 7.0 - Radiation Protection (complete) } \\
8.0 \text { - Hazardous Materiais Protection (complete) } \\
\text { 9.0 - Radioactive and Hazardous Waste Management (complete) } \\
\text { 16.0 - Provisions for Decontamination and Decommissioning (complete) }\end{array}$ \\
\hline $\mathrm{V}$ & $\begin{array}{l}\text { 3.0 - Hazards and Accident Analysis (complete) } \\
\text { 4.0 - Safety Structures, Systems, and Components (complete) }\end{array}$ \\
\hline VI & $\begin{array}{l}\text { 10.0 - Initial Testing, In Service Surveillance, and Maintenance (complete) } \\
\text { 11.0 - Operational Safety (complete) } \\
\text { 12.0 - Procedures and Training (complete) } \\
\text { 13.0 - Human Factors (complete) } \\
\text { 14.0 - Quality Assurance (complete) } \\
\text { 15.0 - Emergency Preparedness Program (complete) } \\
\text { 17.0 - Management, Organization, and Institutional Safety Provisions (complete) }\end{array}$ \\
\hline VII & $\begin{array}{l}5.0 \text { - Derivation of Technical Safety Requirements (complete) } \\
\text { Executive Summary (complete) } \\
\text { TSR Document (complete) }\end{array}$ \\
\hline VIII & Complete SAR - Submitted for approval \\
\hline
\end{tabular}


of the facility design and construction activities. The objective of the phased approach will be to obtain early review by the DOE staff and early resolution of the DOE comments on the phased SAR chapters as they are prepared. The project anticipates that by obtaining DOE involvement as early as practical in the review of the SAR, the SAR review and approval will avoid unnecessary delays in support of the project's need to expedite operation of these facilities.

The phased review process for the CVD facility SAR allows authorization of construction prior to the complete SAR approval. The initial construction will be authorized as a result of the use of a safety analysis package created to initiate the civil/structural construction work, similar to that of the CSB initial construction support phase.

The second and third SAR package supports completion of civil/structural construction and initiation of process equipment installation. As more details of design/construction are known, the exact phasing of the SAR for this facility will be provided in this document and in the approved project schedule. The remaining submittals are for review and approval of the completed SAR chapters. The submittals support development of the facility operating procedures, personnel training, and initiation of the ORR.

Figure 2-7 depicts the general diagrammatic schedule layout of the phased preparation and review process that will be utilized for the CVD facility. Table 2-12 describes the SAR chapters and other documentation provided in these three phases.

\subsubsection{Hot Conditioning Annex Facility}

Hot conditioning will be accomplished in an annex to the CSB. The authorization basis of the facility will be documented in a HCS SAR, as an addendum to the CSB SAR. This addendum will contain all the interactions between the CSB and the hot conditioning processes and structures. The addendum is intended to be deleted when the hot conditioning process is no longer necessary, without affecting the remainder of the CSB SAR.

Construction of the civil/structural portion of the annex will be supported by the first phase of the addendum in a similar manner as that of the CSB and CVD. However, the support documentation will greatly benefit from the CSB initial below-grade construction package and the CSB package supporting operating deck construction.

The initiation of process equipment installation is supported by phased SAR submittals II, III, and IV. The remaining submittals are for DOE review and approval of the completed SAR chapters and the complete SAR.

Figure 2-8 depicts the general diagrammatic schedule layout of the HCS facility phased SAR addendum. Table 2-13 describes the SAR chapters and other documentation provided in these phases. 
Figure 2-7. Diagrammatic Schedule of CVD Phased SAR Activities.

1996
\begin{tabular}{|l|l|l|l|l|l|l|l|l|l|l|l|l|l|l|l|l|l|l|l|l|}
\hline Jan & Feb & Mar & Apr & May & Jun & Jut & Aug & Sep & Oct & Nov & Dec & Jan & Feb & Mar & Apr & May & Jun & Jul & Aug & Sep \\
\hline
\end{tabular}

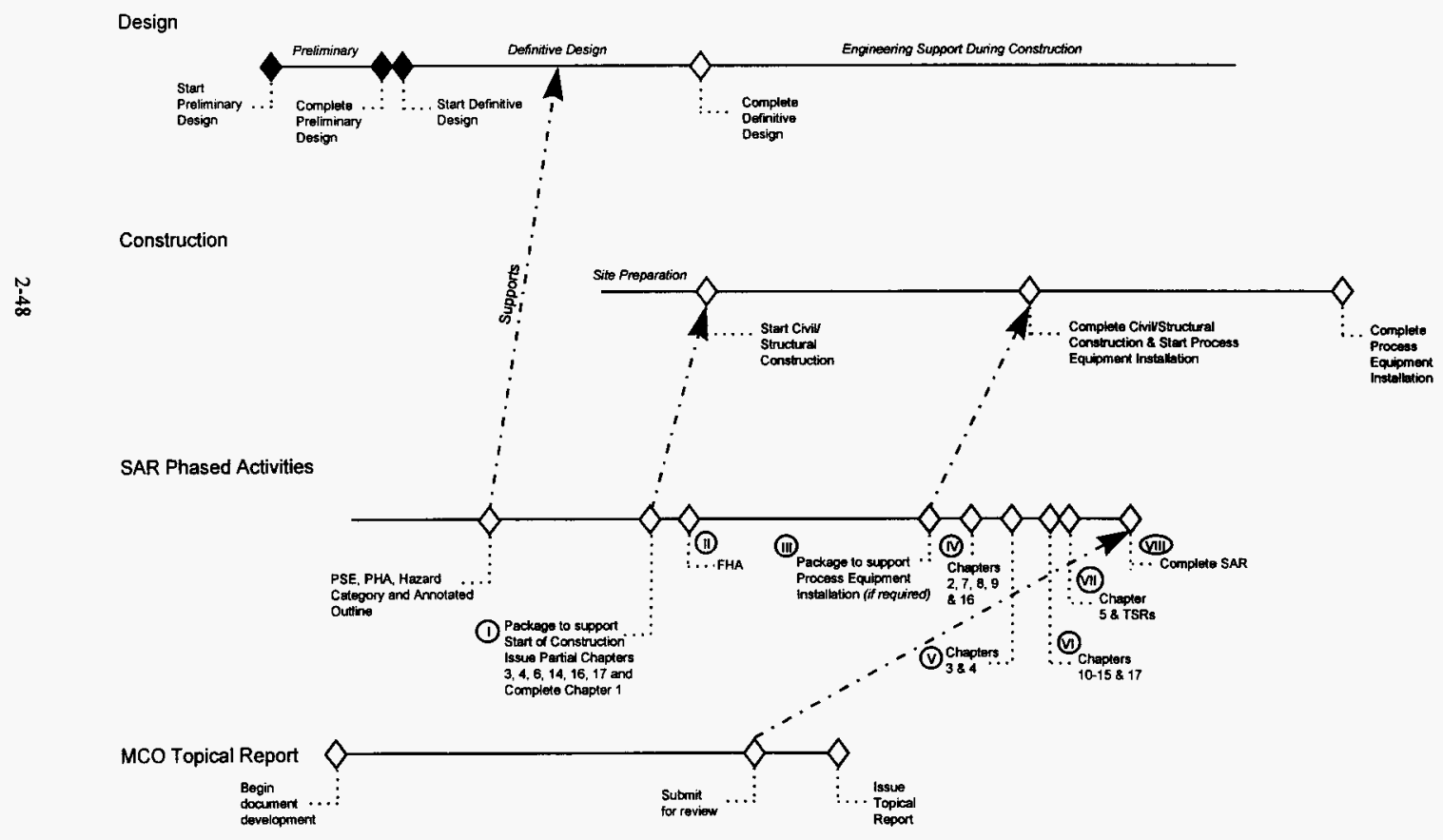


Table 2-12. Cold Vacuum Drying Phased Safety Analysis Report Approach.

\begin{tabular}{|c|c|}
\hline Submittals & Contents \\
\hline I & $\begin{array}{l}\text { Construction Support Phase } \\
\text { 1.0 - Site Characteristics (complete) } \\
\text { 3.0 - Hazards and Accident Analysis (partial) } \\
\text { 4.0 - Safety Structures, Systems, and Components (partial) } \\
\text { 6.0 - Prevention of Inadvertent Criticality (partial) } \\
\text { 14.0 - Quality Assurance (partial) } \\
\text { 16.0 - Provisions for Decontamination and Decommissioning (partial) } \\
\text { 17.0 - Management, Organization, and Institutional Safety provisions (partial) }\end{array}$ \\
\hline II & Fire Hazards Analysis \\
\hline III & $\begin{array}{l}\text { Equipment Installation Phase } \\
\text { 2.0 - Facility Description (partial) } \\
\text { 3.0 - Hazards and Accident Analysis (partial) } \\
\text { 4.0 - Safety Structures, Systems, and Components (partial) } \\
\text { 6.0 - Prevention of Inadvertent Criticality (complete) } \\
\text { 14.0 - Quality Assurance (complete) } \\
\text { 16.0 - Provisions for Decontamination and Decommissioning (partial) } \\
\text { 17.0 - Management, Organization, and Institutional Safety provisions (complete) }\end{array}$ \\
\hline IV & $\begin{array}{l}2.0 \text { - Facility Description (complete) } \\
7.0 \text { - Radiation Protection (complete) } \\
\text { 8.0 - Hazardous Materials Protection (complete) } \\
\text { 9.0 - Radioactive and Hazardous Waste Management (complete) } \\
16.0 \text { - Provisions for Decontamination and Decommissioning (complete) }\end{array}$ \\
\hline $\mathrm{V}$ & $\begin{array}{l}\text { 3.0 - Hazards and Accident Analysis (complete) } \\
\text { 4.0 - Safety Structures, Systems, and Components (complete) }\end{array}$ \\
\hline VI & $\begin{array}{l}\text { 10.0 - Initial Testing, In Service Surveillance, and Maintenance (complete) } \\
\text { 11.0 - Operational Safety (complete) } \\
\text { 12.0 - Procedures and Training (complete) } \\
\text { 13.0 - Human Factors (complete) } \\
\text { 14.0 - Quality Assurance (complete) } \\
\text { 15.0 - Emergency Preparedness Program (complete) } \\
\text { 17.0 - Management, Organization, and Institutional Safety Provisions (complete) }\end{array}$ \\
\hline VII & $\begin{array}{l}5.0 \text { - Derivation of Technical Safety Requirements (complete) } \\
\text { Executive Summary (complete) } \\
\text { TSR Document (complete) }\end{array}$ \\
\hline VIII & Complete SAR - Submitted for approval \\
\hline
\end{tabular}


Figure 2-8. Diagrammatic Schedule of HCS Phased SAR Activities.

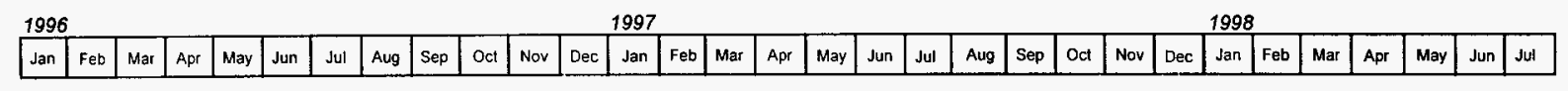

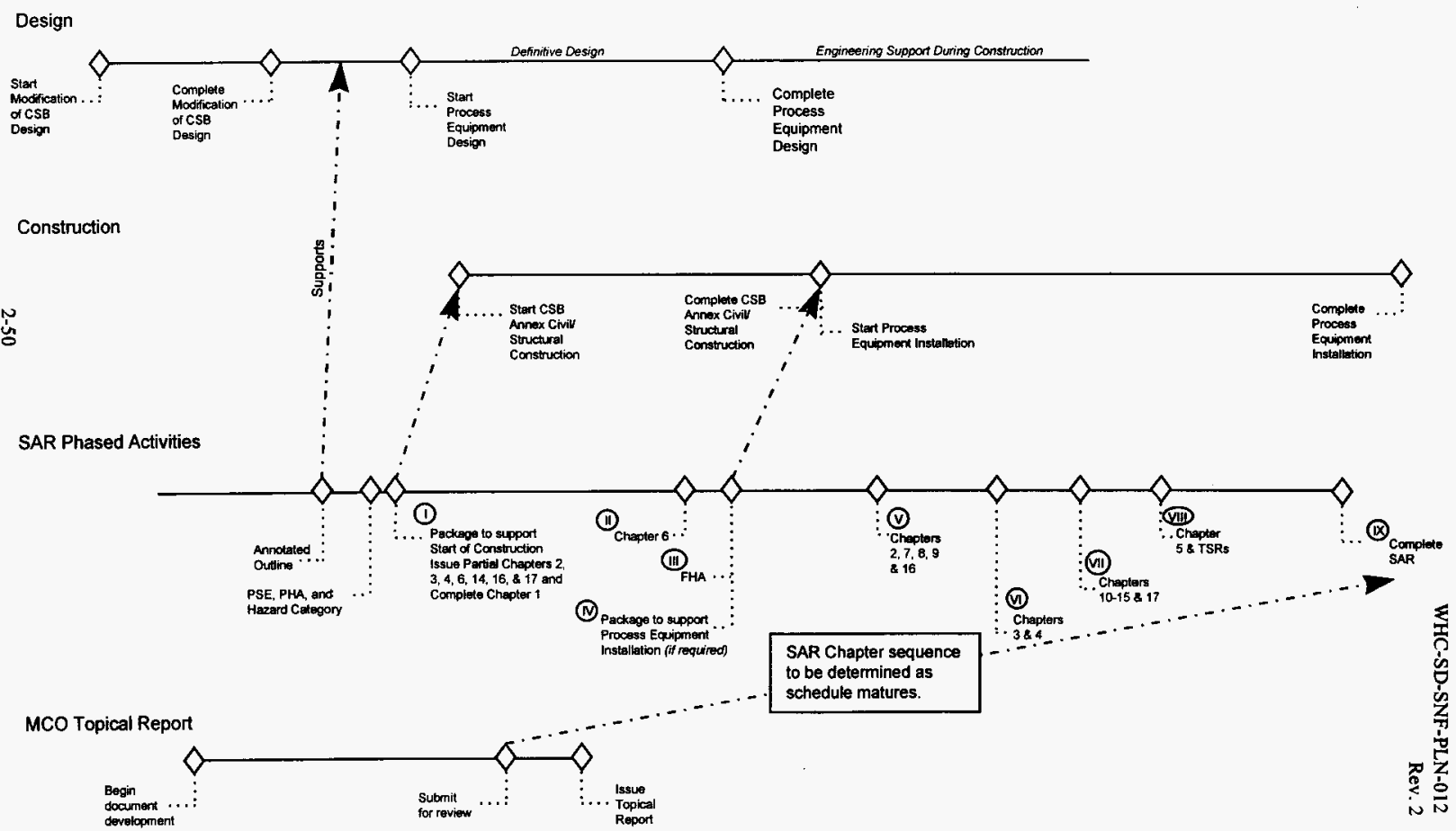


Table 2-13. Hot Conditioning Annex Phased Safety Analysis Addendum Approach.

\begin{tabular}{|c|c|}
\hline Submittals & Contents \\
\hline I & $\begin{array}{l}\text { Construction Support Phase } \\
\text { 2.0 - Facility Description (partial) } \\
\text { 3.0 - Hazards and Accident Analysis (partial) } \\
4.0 \text { - Safety Structures, Systems, and Components (partial) } \\
14.0 \text { - Quality Assurance (partial) } \\
\text { 16.0 - Provisions for Decontamination and Decommissioning (partial) } \\
\text { 17.0 - Management, Organization, and Institutional Safety provisions (partial) }\end{array}$ \\
\hline II & 6.0 - Prevention of Inadvertent Criticality (complete) \\
\hline III & Fire Hazards Analysis \\
\hline IV & $\begin{array}{l}\text { Equipment Installation Phase } \\
2.0 \text { - Facility Description (partial) } \\
3.0 \text { - Hazards and Accident Analysis (partial) } \\
4.0 \text { - Safety Structures, Systems, and Components (partial) } \\
\text { 16.0 - Provisions for Decontamination and Decommissioning (partial) } \\
\text { 17.0 - Management, Organization, and Institutional Safety provisions (partial) }\end{array}$ \\
\hline V & $\begin{array}{l}2.0 \text { - Facility Description (complete) } \\
\text { 7.0 - Radiation Protection (complete) } \\
\text { 8.0 - Hazardous Materials Protection (complete) } \\
\text { 9.0 - Radioactive and Hazardous Waste Management (complete) } \\
\text { 16.0 - Provisions for Decontamination and Decommissioning (complete) }\end{array}$ \\
\hline VI & $\begin{array}{l}\text { 3.0 - Hazards and Accident Analysis (complete) } \\
4.0 \text { - Safety Structures, Systems, and Components (complete) }\end{array}$ \\
\hline VII & $\begin{array}{l}\text { 10.0 - Initial Testing, In Service Surveillance, and Maintenance (complete) } \\
\text { 11.0 - Operational Safety (complete) } \\
\text { 12.0 - Procedures and Training (complete) } \\
\text { 13.0- Human Factors (complete) } \\
\text { 14.0 - Quality Assurance (complete) } \\
\text { 15.0 - Emergency Preparedness Program (complete) } \\
\text { 17.0 - Management, Organization, and Institutional Safety Provisions (complete) }\end{array}$ \\
\hline VIII & $\begin{array}{l}\text { 5.0 - Derivation of Technical Safety Requirements (complete) } \\
\text { Executive Summary (complete) } \\
\text { TSR Document (complete) }\end{array}$ \\
\hline IX & Complete SAR - Submitted for approval \\
\hline
\end{tabular}




\subsubsection{MCO Topical Report}

The MCO Topical Report supports several of the SNF Project SARs and the authorization for MCO procurement. The diagrammatic schedule for the MCO Topical Report is shown on Figure 2-9. The baseline schedule for the MCO Topical Report is included in the SNF Project schedule baseline.

\subsubsection{On-site SNF Transportation Safety}

On-site transportation activities are conducted in accordance with the on-site transportation program as implemented in Hazardous Material Packaging and Shipping, WHC-CM-2-14 (WHC 1995q). The authorization basis for the program is found in DOE-RL letter 95-SWT-186 (Valdez 1995). (Note - a more definitive authorization letter is in the approval cycle at DOE-RL.) On-site transportation is different from off-site transportation, which is regulated by the Department of Transportation.

On-site transportation safety practices are based on elements from the Department of Transportation (49 CFR) and NRC (10 CFR 71) regulations for off-site hazardous materials transportation; the NRC (10 CFR 72) regulations for spent fuel storage, which includes on-site movement of spent fuel; the Contractor facility safety analysis program (WHC-CM-4-46); ALARA principles; and risk management. The program utilizes a risk-based development, operations, and safety analysis process graded by the hazard posed by the material being transported.

Authorization for on-site transportation of SNF is given by the approval of a SARP (onsite). The SARP (on-site) provides the comprehensive safety evaluation to demonstrate compliance with the on-site transportation safety requirements, and the operational and system requirements necessary to ensure compliant operations.

A PDC is prepared as the first step in the development of an on-site transportation system. The PDC provides definition of the material to be transported and establishes its hazard, defines facility interfaces, clarifies the safety analysis requirements based on the hazard, and directs the design activities. The PDC is a baseline document that is approved by the same authorities that approve the SARP (on-site). Preliminary risk-based decisions are finalized in the SARP (on-site).

The SARP (on-site) evaluations consider the package configuration and the transportation activity after the package is secured on the conveyance, and during transport until the system is staged for facility activities at the receiving facility. Loading activities that affect the package during transport are also addressed in the SARP (on-site). 
Figure 2-9. Diagrammatic Schedule of MCO Topical Report.

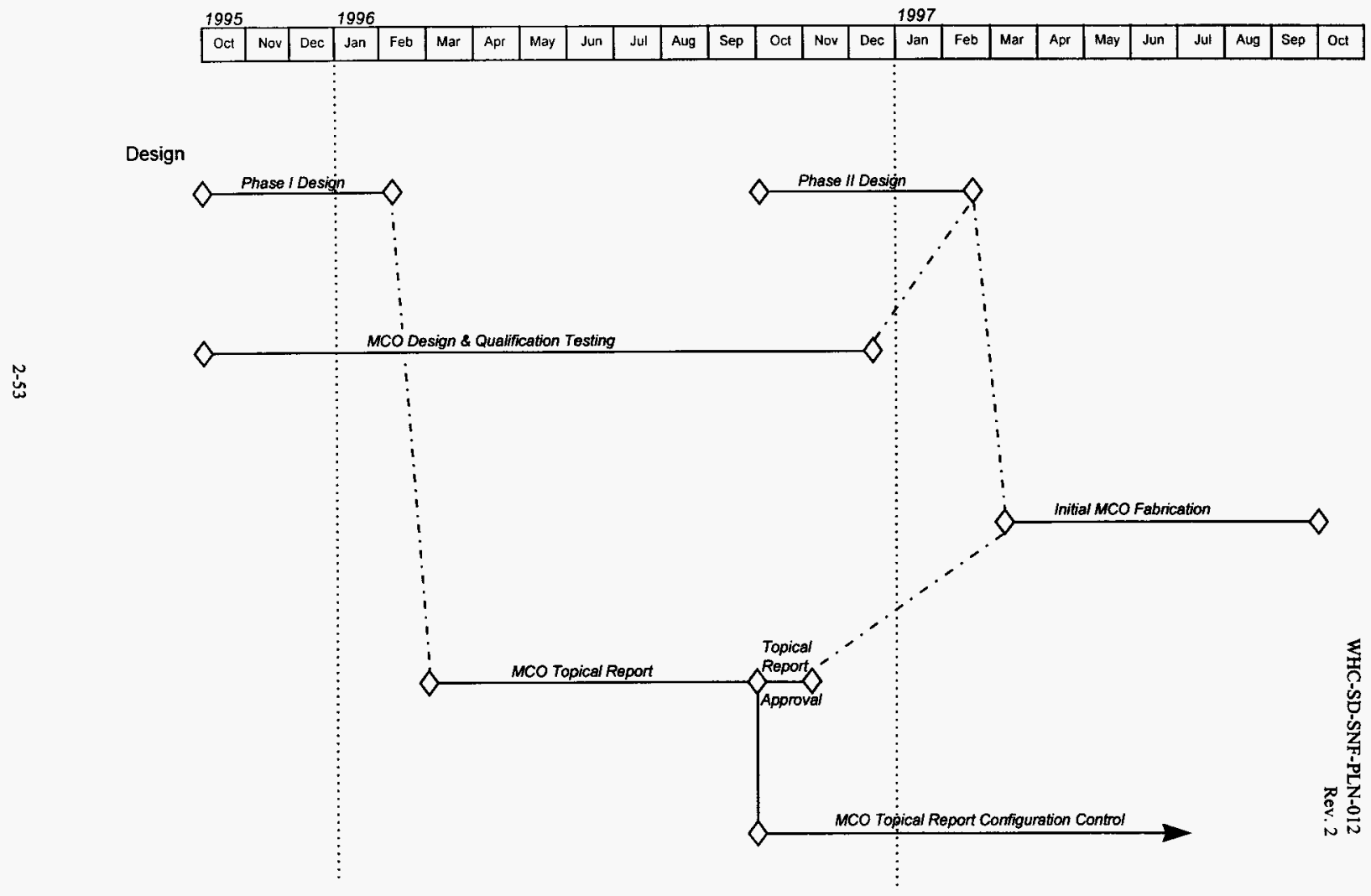


MCO Transportation System. The review and approval process for the MCO transportation system PDC and SARP (on-site) has been clarified in SNF Project Safety Analysis Report for Packaging (SARP) Approval Plan (WHC 1995r). The DOE-RL. Traffic Manager is the final approval authority.

The PDC for the MCO Transportation System defines a packaging system that provides containment, criticality control, and shielding under normal transport conditions and during any credible accident events. Packaging performance criteria are specified as developed from a riskbased failure threshold evaluation.

A preliminary SARP (on-site) was developed and reviewed as part of the MCO Transportation System preliminary design review process. The approval to begin final design of the transportation system was based, in part, on the results of the preliminary SARP (on-site). The SARP (on-site) will be prepared in parallel with the final design. The safety evaluations are being performed independently from the design agent.

The MCO is being developed separately from the MCO Transportation System. The MCO design description and analyses pertinent to transportation will be integrated into the SARP (on-site). Heat transfer, gas generation and chemical reactions, and criticality control are dependent on the MCO design. SARP (on-site) evaluations will verify that the MCO system may be transported in the cask in compliance with the on-site transportation safety requirements.

Sludge Transportation System. The review and approval process for the Sludge Transportation System PDC and SARP (on-site) has been clarified in $K$ Basins Packaging Design Criteria (PDC) and Safety Analysis Report for Packaging (SARP) Approval Plan (WHC 1995s). The DOE-RL Traffic Manager is the final approval authority.

The PDC for the Sludge Transportation System defines a packaging system that provides containment, criticality control, and shielding under normal transport conditions and during any credible accident events. Packaging performance criteria are specified as developed from a riskbased failure threshold evaluation. The SARP (on-site) will be prepared in parallel with the system design.

Other SNF Transportation Systems. There are numerous other transportation activities associated with the SNF Project, including: fuel and sludge characterization, ion exchange disposal, canister disposal, basin filter media disposal, and other spent fuel storage. The on-site transportation associated with these activities will comply with the on-site transportation safety requirements and procedures found in WHC-CM-2-14 (WHC 1995q).

\subsubsection{Construction Safety}

DOE has assigned the Contractor the responsibility and authority for overall direction of assigned projects, which includes the SNF Project. This responsibility includes the prime 
interface with DOE-RL on these projects and oversight of the design, construction, and inspection organizations. In this role, the Contractor's responsibilities include management of construction projects and providing project safety oversight to ensure compliance with the safety and health program requirements as outlined in DOE Order 5480.9A, Construction Safety and Health Program. The Contractor may subcontract day-to-day responsibility for construction safety to the performing construction contractor. The construction safety program, which reflects DOE Order 5480.9A, is documented in WHC-CM-1-10, Safety Manual. The safety program applies to new construction and modifications.

The Contractor construction safety program includes, but is not limited to, the following elements:

- Daily walk-through inspections of the worksite to assess safety and health performance, and corrective action as appropriate.

- Reviews of the project-specific safety and health plan and other relevant safety and health program documentation.

- Pre-job safety meetings.

- Maintenance of accident and injury/illness records and investigation and corrective action as appropriate.

- Review of construction equipment for compliance with applicable OSHA requirements and assurance that employees are qualified to operate such equipment.

- Control of hazardous materials and dangerous wastes in compliance with applicable DOE, federal, state, and local regulations.

Roles and responsibilities for construction project management are documented in the SNF Project PMP (WHC 1995d) and in subproject PMPs.

\subsubsection{Operational Readiness Review/Declaration of Readiness}

The DOE has instituted a process of readiness review and certification by both the operating Contractor and the responsible DOE authorities. Specifically, near completion of the construction phase and following approval of the SAR, the readiness for operation will be assessed in accordance with RLID 5480.31, Startup and Restart of Facilities Operational Readiness Reviews and Readiness Assessments. Approval of the SAR, TSRs, and S/RIDs and completion of the readiness review activities will provide the safety basis for DOE authorization to startup/operate. 
The SNF Project will perform four ORRs to support the numerous system and facility start-ups. A separate Plan of Action will be prepared for each ORR. The ORRs have been organized around the four major SNF Project process steps, as described below:

- The Fuel Retrieval ORR includes SNF retrieval, packaging, loading and transporting fuel. Fuel transportation includes fuel shipment to the CSB.

- The CVD ORR includes SNF vacuum drying and MCO closure.

- The CSB ORR includes SNF receiving, SNF preparation, and placing the MCOs into a CSB interim storage tube.

- The HCS ORR includes fuel conditioning in the HCS Annex to the CSB.

A common SNF operations management system will be implemented at the SNF facilities. This system includes plans, procedures, personnel training, organizational arrangements, and operations staff. The ORR for the FRS will include the review of the operations management system. The other ORRs will not require a repeat of this review.

The ORRs will be performed following a management assessment of readiness to start operations. Responsible SNF Project line management efforts to achieve readiness will be conducted in accordance with the SNF Project PMP, a start-up plan, and other project management documents. Once SNF Project line management has determined that readiness has been achieved and satisfies the prerequisites specified in the Plan of Action, SNF Project ORR will commence. Each Contractor ORR will be followed by a DOE ORR. The Secretary of Energy or delegate has approval authority for initiation of radioactive operations for the major SNF Project activities.

The ORR process focuses on the readiness of management systems and all hardware, personnel, procedures, and the ability to comply with the applicable requirements. The purpose of the ORR is to verify that the nuclear facility being started up meets the following criteria:

- Constructed in accordance with the approved design;

- Can be operated safely;

- Will be operated, maintained, and supported by trained and competent personnel;

- Designed and will be operated in conformance with applicable DOE Orders and regulatory requirements;

- Will be operated so that no undue risk to employees, the public, or the environment will result; and 
- All of the above items are properly and adequately documented.

Items important in determining operational readiness of the systems and facilities are approved safety documentation, approved environmental documentation, a satisfactory and safe working environment, and compliance with applicable Rules and DOE Orders. The ORR will verify that the necessary, approved requirements documentation is in place, and that the procedures, safe boundaries, personnel, equipment, and systems support the approved requirements. The ORR team will not approve the base document, but will only verify that it is approved and that it has been implemented.

A graded approach is planned for the SNF Project ORR by which the levels of analysis, documentation, and actions necessary to comply with a requirement are commensurate with: (1) the relative importance to safety, safeguards, and security; (2) the magnitude of any hazard involved; (3) the life cycle stage of a facility; (4) the programmatic mission of the facility; (5) the particular characteristics of the facility; and (6) other factors identified in the preliminary safety analysis.

The Contractor's ORR team will conduct performance-based reviews using field observations of personnel activity, whenever possible. For example, observing a dry run of processes conducted in the CVD will enable verification of operator knowledge of procedures; the adequacy of procedures for safe performance; readiness of tools, equipment, and instrumentation; conduct of operations practices, off-normal and emergency operation, and other items. When supplemented with, for example, personnel interviews and a detailed review of training requirements and records, this performance-based approach will provide a high degree of confidence in the acceptability of the Contractor's readiness preparations.

SNF Project ORR activities will be documented in a formal SNF Project ORR Report. When SNF Project programmatic pre-start findings have been resolved, the Approval Authority will prepare and forward a Readiness to Proceed Memorandum to DOE-RL. All actions required for startup or restart shall be completed with the exception of a manageable list of open pre-start findings. These finding must have a well-defined schedule for closure to allow review of the results of the closure process by the DOE ORR team.

Smaller activities at the $\mathrm{K}$ Basins (e.g., debris and sludge removal) will be evaluated using the USQ process on a case-by-case basis. DOE Order 5480.31 will be used to define the necessary readiness review actions and authorization steps.

\subsubsection{Certification of Readiness}

The new SNF Project facilities are currently Hazard Category 2 facilities, which require an ORR per the requirements of RLID 5480.31. Specifically, the responsible Contractor and DOE field management must certify that the DOE-imposed applicable requirements are 
demonstrably in place and functioning effectively, and designate the authorizing DOE official. This will be provided by successful completion of the ORR.

\subsubsection{Authorization to Operate}

Authorization to operate is based on DOE approval of the S/RIDs, the SAR/TSR/SARP, and completion of the ORR, as required. Authorization to operate is provided to the Contractor for the subject facility by official letter from the DOE.

The $\mathrm{K}$ Basins are currently operating under an approved SAR and S/RID. Modifications against that authorization basis are assessed via the USQ screening process. However, if necessary, as indicated via the USQ process, a specific SAR or OSR amendment would be pursued. DOE-RL would review and approve that amendment allowing such operation.

\subsubsection{K Basins Facility Operations}

Operational surveillance activities at the $\mathrm{K}$ Basins are documented in the $\mathrm{K}$ Basins OSR (WHC 1996d). Compliance activities at the K Basins are instituted by a self assessment process to ensure that the facility S/RID requirements are being met in the work processes. The selfassessment process is procedurally defined in the $\mathrm{K}$ Basins Administrative Procedure, AP-010, K Basins Self Assessments (WHC 1995t).

\subsubsection{Other Spent Nuclear Fuel}

The SNF Project has varied responsibility for management of the SNF located at Hanford facilities other than the K Basins (i.e., "other SNF"). These SNF inventories include: defense production reactor SNF at the N Reactor Basins; Fast Flux Test Facility (FFTF) SNF; Neutron Radiography Facility (NRF) Training Reactor and Isotopics Production General Atomics (TRIGA(R) SNF from the 308 Building annex; Shippingport Pressurized Water Reactor (PWR) Core 2 SNF at T Plant; TRIGA@ SNF and miscellaneous SNF at the 200 West Area Low-Level Burial Grounds (LLBG); miscellaneous SNF located at the Plutonium Finishing Plant (PFP); and Light Water Reactor (LWR) and miscellaneous SNF located at the 324, 325, and 327 Buildings. The SNF Project also has responsibility for the defense production reactor SNF from the PUREX Plant, which was transferred to the K West Basin in October 1995 and will be managed consistent with the K Basins SNF IPS.

The locations and quantities of the other SNF inventories are summarized in Table 2-14. This table is based on the current Hanford SNF baseline inventory. The ISMP will be revised to include any SNF not currently included in the baseline, as those fuels are identified. 
Table 2-14. Hanford Other Spent Nuclear Fuel Inventories.

\begin{tabular}{|c|c|c|c|}
\hline SNF Inventories & Storage Location & $\begin{array}{l}\text { Quantity } \\
\text { (Metric Tons of } \\
\text { Heavy Metal) }\end{array}$ & Material/Packaging Concerns \\
\hline Fast Flux Test Facility & $\begin{array}{l}\text { Fast Flux Test } \\
\text { Facility }\end{array}$ & 11.0 & $\begin{array}{l}\text { No significant material concern; facility deactivation requires } \\
\text { alternate storage. }\end{array}$ \\
\hline Shippingport & T Plant & 15.8 & $\begin{array}{l}\text { Aging facility; inefficient wet storage; facility mission } \\
\text { necessitates alternate storage. }\end{array}$ \\
\hline $\begin{array}{l}\text { Light Water Reactor and } \\
\text { Miscellaneous Fuels }\end{array}$ & $\begin{array}{l}324,325,327 \\
\text { Buildings }\end{array}$ & 2.3 & $\begin{array}{l}\text { Dispersible material clean-up and facility vulnerability } \\
\text { corrective actions necessitate alternate fuel storage; safety } \\
\text { authorization not to current standards. }\end{array}$ \\
\hline NRF TRIGA@ Fuel & $\begin{array}{l}400 \text { Area Interim } \\
\text { Storage Area }\end{array}$ & 0.02 & $\begin{array}{l}\text { Recently transferred to } 400 \text { Area from } 308 \text { Building to } \\
\text { support facility deactivation. }\end{array}$ \\
\hline $\begin{array}{l}\text { LAMPRE Fuel } \\
\text { University of Washington Fuel }\end{array}$ & $\begin{array}{l}\text { Plutonium } \\
\text { Finishing Plant }\end{array}$ & $8.4 \times 10^{-5}$ & $\begin{array}{l}\text { LAMPRE fuel repackaging may be required for interim } \\
\text { storage. } \\
\text { SNF Project assumes that slightly irradiated University of } \\
\text { Washington fuel will not be managed and dispositioned as } \\
\text { SNF, based on preliminary input from EM-67. }\end{array}$ \\
\hline $\begin{array}{l}\text { TRIGA@ Fuel and } \\
\text { Miscellaneous Fuels }\end{array}$ & $\begin{array}{l}\text { Low-Level Burial } \\
\text { Grounds }\end{array}$ & 0.02 & $\begin{array}{l}\text { Material buried with transuranic waste in solid waste } \\
\text { management system. Retrieval in parallel with solid waste } \\
\text { retrieval planned to minimize personnel exposure/risks. } \\
\text { Quantity includes only TRIGA@ SNF. EM-67 is reviewing } \\
\text { classification of other LLBG SNF materials, which will } \\
\text { likely increase total LLBG SNF quantity. }\end{array}$ \\
\hline TOTAL & Hanford Site & 32 & \\
\hline
\end{tabular}


The SNF Project responsibilities for management of the other SNF are being finalized through agreements established by MOUs between affected DOE-RL organizations. The SNF Project responsibilities will include actions to support:

- Consolidating defense production reactor SNF from the N Reactor Basins at the K Basins;

- Implementing near-term dry storage of current 300 Area and 400 Area SNF inventories in storage casks at the 400 Area ISA;

- Achieving and maintaining long-term interim dry storage of the SNF at the CSB, a contiguously located 200 Area Interim Storage Area, and the PFP.

Based on approved MOUs and anticipated agreements in MOUs, a description of the planned activities for each SNF type and the approach for developing and maintaining safety authorization bases that satisfy SNF Project requirements for management of these SNF inventories are as follows:

- Bechtel Hanford Incorporated plans to retrieve sludge from the N Reactor Basins floor in 1996. Bechtel estimates that up to 0.5 metric tons heavy metal of N Reactor SNF may be remaining in the sludge. Any SNF recovered during the N Reactor Basins deactivation will be transferred to the $\mathrm{K}$ West Basin for consolidated management with other N Reactor SNF. The current project baseline assumes the SNF will be received at the $\mathrm{K}$ Basins in Mark II canisters in existing well cars, without modification to the existing K Basins SAR.

Potentially, the schedule for SNF retrieval from the N Reactor Basin will not enable shipment prior to initiating modifications to the $\mathrm{K}$ West Basin south load-out pit. If this occurs, an alternate shipping plan will be required that could involve use of a different shipping cask. A K Basins SAR revision would then potentially be required in addition to a SARP modification to support an alternate shipping plan. The SNF Project would, at a minimum, be responsible for establishing and approving the $\mathrm{K}$ Basins SAR revision and reviewing and concurring on the SARP revision. If an alternate shipping plan is required, the safety management plan will be revised to incorporate the requisite safety documentation modifications.

- The FFTF Transition Project is removing SNF from in-sodium storage, placing up to seven assemblies into Core Component Containers (CCCs), and inserting each CCC into an Interim Storage Cask (ISC) for dry interim storage. This activity is on-going and will be completed in late 1998 . The FFTF SNF inventory will require approximately $50 \mathrm{ISCs}$. 
After each ISC is loaded, the ISCs will be moved to the adjacent 400 Area ISA with the exception of two or three ISCs requiring enhanced security. These ISCs will be transferred directly to the protected area at the PFP. The ISCs at the 400 Area ISA will be transferred later to the 200 Area ISA for storage until transfer off-site.

The 400 Area ISA will be managed by the FFTF Transition Project until turnover to the SNF Project. The SNF Project baseline assumes turnover will occur concurrent with transfer of FFTF to the Environmental Restoration Contractor, consistent with the approved MOU for management of FFTF SNF.

The safety authorization bases for storage of FFTF SNF at the 400 Area ISA will be approved and maintained by revisions to Appendix $\mathrm{H}$ of the FFTF SAR. To support startup of the 400 Area ISA, the FFTF SAR was revised to include a chapter in Appendix $\mathrm{H}$ for FFTF SNF cask storage at the 400 Area ISA. The current safety authorization basis was developed based on the intent to demonstrate nuclear safety equivalent to comparable NRC-licensed facilities, compliance with 400 Area specific requirements, and compliance with on-site requirements. The safety authorization basis currently addresses only standard driver fuel assemblies. Criticality safety analyses are documented separate from the FFTF SAR, and are also required to support SNF storage at the 400 Area ISA.

The FFTF Transition Project is responsible for maintaining the FFTF SAR until turnover of the 400 Area ISA to the SNF Project. The SNF Project will review and concur with Appendix $\mathrm{H}$ revisions related to FFTF SNF during FFTF Transition Project ownership of the 400 Area ISA, including revisions that will be required to incorporate the remaining FFTF SNF assemblies into the safety authorization basis.

The SNF Project will establish and approve revisions required after turnover of the 400 Area ISA to the SNF Project, including a revision that will be needed to support transfer of the ISCs to the 200 Area ISA.

Additionally, the FFTF Transition Project is responsible for establishing and approving a SARP to enable shipment of the FFTF SNF to the 200 Area directly or after storage at the 400 Area ISA. An initial revision of the SARP was issued that envelopes shipments of unirradiated or slightly irradiated SNF to the PFP in the ISCs. An additional revision will be completed to address the remaining SNF transfer to the 200 Area ISA. The SNF Project will review and concur with the SARP.

As part of the reviews of the existing Appendix $\mathrm{H}$ chapter for FFTF SNF and the initial SARP, the SNF Project documented multiple issues that require resolution for the safety authorization basis to satisfy requirements for nuclear safety equivalent to comparable NRC-licenced facilities and to ensure compatibility of the storage system with later requirements for transfer of the ISCs to the 200 Area ISA. The SNF Project will participate in issue resolution. 
- TRIGA® SNF previously stored at the 308 Building annex was loaded into six NRF TRIGA $\otimes$ casks and transferred to the 400 Area ISA for storage in December 1995. TRIGA@ Fuel Follower Control Rods were shipped at the same time and are being stored in two U.S. Department of Transportation (DOT) $6 \mathrm{M}$ containers. The NRF TRIGA@ casks and DOT $6 \mathrm{M}$ containers are stored in a vault module at the 400 Area ISA.

The NRF TRIGAB casks were designed with the intent of securing a Certificate of Compliance ( $\mathrm{C}$ of $\mathrm{C}$ ) to enable shipment of the casks off-site without repackaging. The DOT 6M casks are specification packages, and can be used for off-site shipment. The concrete vault will provide enhanced shielding during storage to meet the 400 Area ISA fence line maximum dose rate requirement of $0.5 \mathrm{mrem} / \mathrm{hr}$. Current plans are to transfer the NRF TRIGA $\otimes$ casks, DOT $6 \mathrm{M}$ containers and vault to the 200 Area ISA, consistent with the FFTF SNF ISCs.

The FFTF SAR was revised to include a chapter for NRF TRIGA SNF storage at the 400 Area ISA. A separate document was issued and released for the criticality safety analyses. Additionally, a SARP was issued to address the shipment of the NRF TRIGA $B$ SNF from the 308 Building annex to the 400 Area. The SAR revision was developed and approved by the SNF Project, including the SNF Project SEAC subcouncil, but was not reviewed or approved by the DOE-RL Spent Nuclear Fuel Project Division (SFD) due to schedule constraints. The SNF Project has recommended that SFD review and concur with the SAR revision.

During the SAR revision development and approval, an issue was identified on the NRF TRIGA® SNF cask bore seal life and replacement impacts. Demonstration of bore seal leaktightness was identified in the current SARP as a prerequisite for on-site transport and bore seal material is projected to have a minimal life expectancy (i.e., 5-10 years). The bore seal is not a requirement for storage of the SNF per the FFTF SAR. The SNF Project is developing a seal inspection/replacement plan to address the seal issue. If action is required for seal replacement or testing at the 400 Area ISA, a FFTF SAR revision may be required. A SARP revision may be completed to take credit for a longer seal life. This would enable transport from the 400 Area without seal replacement.

Additionally, the SNF Project will also be responsible for updating the NRF TRIGA cask SARP, if necessary, immediately prior to transport to the 200 Area.

- Two BWR assemblies and five PWR assemblies and miscellaneous pins and pieces stored primarily in the 324 Radiochemical Engineering Cells will be canistered by Pacific Northwest National Laboratory (PNNL) and transferred to NAC-1 casks. The NAC-1 casks will be qualified for both on-site shipping and storage of the LWR SNF. The casks will be shipped to the 400 Area ISA for storage. PNNL is performing 
activities to complete removal of the B Cell SNF by the end of 1996 . The casks will later be relocated to the 200 Area ISA, consistent with the FFTF SNF.

PNNL is currently preparing a revision to the FFTF SAR to add a chapter to Appendix $\mathrm{H}$ for storage of the LWR SNF in NAC-1 casks at the 400 Area ISA. Documentation for the criticality analyses is being prepared concurrently. The SNF Project will review and concur with the FFTF SAR revision prior to the SNF transfer to the 400 Area.

PNNL is also responsible for preparation of the SARP to enable transport of LWR SNF from the 324 Building to the 400 Area ISA in NAC-1 casks, and subsequent transfer from the 400 Area ISA to the 200 Area ISA. The SNF Project is responsible for review and concurrence of the SARP.

FFTF pins that are currently located at the 300 Area will be returned to FFTF for disposition with the remainder of the FFTF SNF. The SNF Project is not required to review the safety authorization basis for the transfer from the 300 Area to the 400 Area. No supplemental documentation will be required to implement interim storage of the SNF at the 400 Area.

Several containers of SNF materials managed as remote-handled transuranic waste are also stored at the 324/325/327 Buildings. The material will potentially be reclassified as SNF, based on EM-67 discussions with the Waste Isolation Pilot Project. If these materials are reclassified, repackaging at the 300 Area and transfer for storage at the 200 Area ISA is likely. If the materials are reclassified as SNF, the ISMP will be revised to incorporate the added scope.

- The SNF Project plans to retrieve the 72 Shippingport PWR Core 2 assemblies at T Plant, place this SNF into 18 storage containers similar the K Basins SNF MCOs, and transfer the loaded containers to the CSB vault for interim storage. Detailed plans for the activity are being developed. The SNF Project currently assumes that T Plant will provide modifications to the T Plant SAR to enable activities to occur within $T$ Plant and that the SNF Project will be responsible for a SARP amendment to the $\mathrm{K}$ Basins SNF transport cask SARP and a revision to the CSB SAR to accommodate the PWR Core 2 SNF.

Because of schedule issues, use of a storage cask or dual-purpose cask for the PWR Core 2 SNF interim storage is being evaluated as a contingent approach. If this approach is utilized instead, the ISMP will be revised to reflect a separate SARP and CSB SAR modification for cask storage by the SNF Project instead of the baseline approach.

- The SNF Project will construct a 200 Area ISA. The SNF Project will subsequently transfer 400 Area ISA SNF to the 200 Area ISA for interim storage. The CSB will 
support interim storage operations at the 200 Area ISA. The CSB SAR will be amended by the SNF Project to cover the other SNF, including fuel storage and maintenance operations at both the CSB and 200 Area ISA. Additionally, a CSER will be completed.

- Three fuel types are or will be stored at PFP: LAMPRE SNF, FFTF SNF, and University of Washington High-Enriched Uranium SNF. Because of physical differences, the storage systems for each of these SNF types will vary. The planning basis assumes that these SNF inventories will remain at PFP until transport for final disposition, except for potential repackaging at the CSB to satisfy interim storage criteria.

Currently, the LAMPRE SNF is packaged in three EBR-II casks, which have primarily been used as on-site transportation casks. The SNF was initially managed as remote-handled transuranic material and has only recently been relocated to the protected area at PFP. The three casks are stored inside a concrete vault to provide an additional security barrier and supplement the casks' lead shielding. A review of the cask for continued dry storage will be completed. The LAMPRE SNF will be repackaged if necessary for interim storage. At a minimum, the SNF will be repackaged prior to transport off-site for final disposition.

The ISCs containing FFTF SNF designated for storage at PFP will be transported to an outdoor location inside PFP's protected area for storage on a precast concrete pad. This transfer is expected to take place by November 1998 as discussed above.

The PFP Transition Project is responsible for establishing and maintaining the safety authorization basis for storage of the SNF at PFP. The SNF Project will review the existing authorization basis for storage of the LAMPRE SNF and identify any deficiencies to the PFP Transition Project for resolution. The SNF Project will review and concur with the revision to the PFP SAR for the FFTF SNF storage. The SNF Project will be responsible for the one-time Safety Evaluation for Packaging, the CSB SAR revision, and the SARP for the repackaged SNF that will be required to support transport of the LAMPRE SNF to the CSB for repackaging, repackaging the SNF, and returning the repackaged SNF to PFP for interim storage, if required.

Based on preliminary discussions with EM-67, slightly irradiated fuel from the University of Washington will be stored at PFP, but is not likely to be managed as SNF. Contingent on formal direction from EM-67, the SNF Project will not be responsible for any aspect of managing the University of Washington fuel.

- Thirteen drums of Oregon State University TRIGA $\otimes$ SNF are buried under four feet of soil in Trench 7 of the 218-W-4C Burial Facility of the 200 West Area LLBG in TRIGA $($ Standard Fuel Element Storage Drums. A total of 90 TRIGA $\otimes$ elements are stored in the drums. 
The SNF at the LLBG will be exhumed simultaneous with solid waste retrieval, which is currently planned for 2005 by the SNF Project baseline. The retrieval may occur as late as 2015-2016 based on recent input from the Solid Waste Program. The drums will be overpacked and transferred to the CSB for repackaging in an approved storage canister. The canistered SNF will be staged at the 200 Area ISA until shipment off-site for final disposition.

Responsibilities for these actions are currently being defined. The SNF Project assumes that the Solid Waste Program will develop safety documentation to support SNF retrieval, overpacking, and transfer to the CSB. The SNF Project will concur on the documentation for all actions except retrieval. The SNF Project will be responsible for the CSB SAR amendment to support repackaging and storage at the 200 Area ISA.

Several casks of SNF materials managed as remote-handled transuranic waste are also stored at the LLBG. The material will potentially be reclassified as $\mathrm{SNF}$, based on EM-67 discussions with the Waste Isolation Pilot Project. If these materials are reclassified, transfer to the CSB and repackaging for storage at the 200 Area ISA is likely. The SNF Project assumes the responsibilities would be equivalent to those established for the Oregon State University TRIGA® SNF, although schedule drivers may reflect the need for earlier transfer of the materials. If the materials are reclassified as SNF, the ISMP will be revised to incorporate the added scope.

- The SNF Project will transload sodium-bonded FFTF SNF from Interim Storage Casks into T-3 casks for transport to Argonne National Laboratory - West (ANL-W) for treatment prior to final disposition. The sodium bonded FFTF SNF will be initially stored in ISCs and later transloaded into T-3 Casks at the CSB, pending the results of an on-going evaluation. The $\mathrm{C}$ of $\mathrm{C}$ for the T-3 Cask is currently being amended to accommodate full assemblies or an increased number of pins to curtail the number of shipments to ANL-W. The total number of SNF shipments will be eight, consisting of six assemblies and two pin containers. The FFTF Transition Project is responsible for the current $\mathrm{C}$ of $\mathrm{C}$ renewal.

The CSB SAR will be revised for actions to enable transloading at the CSB. The T-3 $\mathrm{C}$ of $\mathrm{C}$ will be modified and renewed to support the transfer to ANL-W, as necessary.

- Transfer of other SNF, except sodium-bonded FFTF SNF, off-site for final disposition will occur after 2015. The current baseline assumes a transloading system will be provided to transfer all SNF inventories into Multi-purpose Canisters (MPCs). The Office of Civilian Radioactive Waste Management (OCRWM) recently revised the planning assumptions for receipt of SNF and has tentatively agreed that SNF could be shipped instead in MCOs or equivalent size overpacks. Due to facility requirements and associated costs, the SNF Project baseline will likely be modified to 
eliminate the MPC transloading capability after receipt of formal input from EM-67 or OCRWM.

Based on the projected requirements, the CSB SAR will require modification to support potential overpacking of FFTF CCCs, MCOs and other SNF canisters, potential repackaging of miscellaneous SNF, and loading of all SNF containers into a transport cask for off-site shipments. A C of C will be required to enable off-site shipment of the SNF. The SNF Project's successor organization will be responsible for the CSB SAR revision and ensuring a $\mathrm{C}$ of $\mathrm{C}$ is established for the off-site shipment.

The other projects, operational surveillance, and compliance activities will be described in later revisions to this ISMP. 


\subsection{TECHNICAL SUPPORT ACTIVITIES}

The safety analysis process: (1) provides systematic identification of hazards for each SNF Project subproject; (2) identifies and analyzes the adequacy of the measures taken to eliminate, control, or mitigate the identified hazards; (3) evaluates potential accidents; (4) identifies structures, systems, and components, operational limits, and administrative controls necessary to manage the risks posed by the hazards; and (5) documents the facility safety basis in the safety analysis or SAR, TSRs, and commitments. Achieving this for the SNF Project requires close integration of design and safety analysis activities with the identification of appropriate technologies for application by the projects, development of analytic processes and safety models, validation of the model assumptions via either literature review or by characterization of the fuel and sludge, testing, and systematic documentation of the evaluations.

This section provides an overview of the technical support activities that are detailed in program-specific schedules, plans, and reports. The project schedules provide the time-phased logic relationships between design, safety analysis, technology acquisition, SNF/sludge characterization and testing programs.

\subsection{OVERVIEW OF MAJOR TECHNICAL SUPPORT PROGRAMS}

The SNF Project has established an aggressive, success-oriented schedule for removal of the deteriorating fuel from $\mathrm{K}$ Basins. The schedule objectives necessitate an implementation of equipment/facility design and construction in parallel with safety analysis and technical issue resolution. Systems engineering methodology is utilized to establish project and subproject missions, functions, and technical requirements. The process hazards assessment and safety analysis methodology described in Section 2.0 of this ISMP identify key process hazards and technical issues that must be resolved to ensure safe and efficient implementation of project objectives. In order to address the major technical challenges of the SNF Project in a timely fashion, the following technical support programs were implemented by the Project:

(1) Technology Acquisition, (2) Project Technical Databook, and (3) Characterization and Testing. Overviews of these three programs are summarized below.

\subsubsection{Technology Acquisition}

The SNF Project Technology Acquisition Program (TAP) (WHC 1995u) was established to systematically identify technical and safety issues associated with the SNF Project, and to establish an overall plan to provide the information and data necessary to close those issues. The initial TAP issue identification was developed by a team composed of project and site representatives from the technology, characterization, design, systems engineering, safety, operations and quality assurance organizations. This team identified tasks required for issue closure and assigned responsibility for subtask performance. The TAP team met weekly as 
analyses and test/characterization information was assembled. The dialogue between key organizational representatives provided a forum for reviewing safety and design impacting information. The initial phase of technology acquisition planning identified major technical uncertainties and activities needed to resolve these issues for each major SNF process element. The TAP identified both safety and process design issues as part of the planning process.

Subsequent TAP planning defined how the TAP tasks supported project-related issue closure and tied to activities in the safety and design schedule. Subsequent revisions of TAP plans involved an issue closure focus rather than the issue identification processes. Activities to close these issues included efforts by Characterization, Technology Acquisition, and subproject Engineering.

One TAP effort produced the Project Technical Databook (WHC 1995v) to compile the generic technical information that is needed by all the SNF subproject elements and safety. The SNF Project Databook is discussed further in Section 3.1.2 below. A success tree analysis was also performed as part of the TAP efforts to systematically establish the basis for the hot conditioning process product criteria (WHC 1996g). This success tree was also used as input to the development of the project safety assessment activities.

Areas that benefit from continued technology acquisition team support include validation of the model assumptions via literature review, performance of analyses integrated across several subprojects, and process verification testing. It is expected that the technology acquisition role in the integration of analyses that transcend single subprojects will be continued at least until the initial fuel moves are completed. Key technology acquisition and characterization integration is contained in the project schedules and supports the Chapter 3 safety analysis planning process described in Appendix A. Actual technology acquisition activities can be found integrated into the subproject-specific planning and schedules. Appendix B identifies key analytical models that support design and safety-related accident analyses (Tables B-1 and B-2) and provides a correlation of all the necessary TAP, characterization, and process engineering reports to the design and safety analysis models being supported (Tables B-3 and B-4).

\subsubsection{SNF Project Technical Databook}

The SNF Project Technical Databook provides integration and consistency in the use of analytic assumptions across the various subprojects by capturing major technical data in a single location that can be referenced. Topics covered include MCO decay heat, radionuclide inventories, material properties for zirconium and fuel (e.g., irradiated uranium air and water vapor reaction rate data or zirconium emmisivity), irradiated uranium reaction rates in water, and sludge drying performance. Characterization data such as confirmation of sludge drying behavior, chemical reactivity, and confirmation of assumptions will be captured in the SNF Project Technical Databook, as well, if generic in nature. 
The SNF Project Technical Databook is being controlled and modified per the requirements of the SNF Project Configuration Management Plan (WHC 1995j). Subprojectspecific data required to support design or safety bases are contained in subproject documentation.

\subsubsection{Characterization and Testing}

Characterization and process testing are closely related in scope and function. Characterization activities provide the physical and chemical characteristics of the feed materials and some of the process streams for a given process. Process testing provides the basic process parameters that will be used in supporting safety analyses and the design process. Process tests will verify the process and safety envelopes, close technical issues, and confirm design/safety models and assumptions (see Appendix B, Tables B-1 and B-2). Frequently, the same information required for the safety or design basis might be provided from either the characterization program or the process test program. An example of such information would be the sludge drying curves that could be classified as either physical characteristics of the feed material or verification of cold vacuum drying process parameters. A close integration of the activities between the characterization and process verification test program is required.

The test programs addressed within this technical support discussion must also be distinguished from the equipment acceptance testing, integrated system testing, and facility cold test programs. These test programs are usually included within the scope of the design authority to assure that the requirements allocation, process, and equipment specifications have been achieved by the facility process elements. These test programs are required, ultimately, to support the readiness review process and facility turnover to operations.

It is expected that all technical information required for process safety and safety analyses will be obtained from the characterization and testing programs, or from existing technical information (WHC 1995v, WHC 1996h). Detailed project integration planning and schedules establish specific logic ties from the planned characterization and testing to the safety analysis process. Appendix A, Figure A-4, provides an example of the logic ties in integration planning.

\subsection{PROCESS CHARACTERISTICS AFFECTING SAFETY ANALYSIS}

Key technical issues have been identified via combined systems engineering, safety analysis, and technology acquisition program activities. In order to support the project's schedule objectives, the SNF Project is organized into several subprojects. However, the major technical issues tend to crosscut many of the subprojects. This section provides a summary level discussion of the major potential process hazards that drive the safety analysis for the subproject elements that involve K Basin fuel handling, processing, and storage. The safety analysis for each of the new SNF Project facilities consider a comprehensive set of equipment failures, design and construction defects, operator errors, natural phenomena hazards (e.g., seismic, wind, etc.), 
external events (e.g., fire), and process hazards that could challenge safety barriers or defense-indepth mitigating features. The summary provided here focuses only on the key technical issues that may require characterization or validation testing to resolve important technical uncertainties.

Table 3-1 identifies the process characteristics and related process hazards that drive the safety analysis for the SNF subprojects for those subproject elements that involve K Basins fuel handling, processing, and storage. Six major categories of process-related hazards have been identified.

The retained water inventory (free water plus adsorbed and chemically bound hydrogen/oxygen) drives the process control strategy for all of the process elements (i.e., subprojects). MCO process and administrative controls are established to optimize process efficiency and maintain process operations within an acceptable safety envelope. Table 3-2 shows a summary of the key process control points and safety envelopes for the major process elements.

Analyses are being performed and documented that address each of the major processrelated hazards. Models will be developed where necessary and conservative enabling assumptions will be established, when necessary, to allow analysis to proceed without impacting project schedules. Characterization testing required to verify enabling assumptions will be performed prior to SAR approval. Table 3-3 identifies key technical products necessary to address the major process-related hazards identified by Table $3-1$ and show the process element supported by these products (see Section 3.4.3).

\subsection{INTEGRATION OF TECHNICAL SUPPORT FOR SUBPROJECTS}

Planning and integration of the needed SNF safety analysis and process design support activities (namely, technology acquisition, characterization, and testing) is in progress and is (or will be) documented in the following SNF Project planning documents:

- SNF Project Technology Acquisition Plan (WHC 1995u),

- Plan for Characterization of K Basins Fuel and Sludge (WHC 1995w),

- SNF Project Integrated Test Strategy (WHC 1996h),

- SNF Project Safety Analysis planning sheets and schedules (See Appendix A).

These plans are living documents. Currently, planning is in varying stages of completion and should be expected to evolve as the SNF Project progresses and as technical understanding 
Table 3-1. Process Characteristics and Potential Hazards that Drive Safety Analysis.

\begin{tabular}{||l|l|l||}
\hline \multicolumn{1}{|c|}{ Process Characteristics } & \multicolumn{1}{|c|}{ Potential Hazard } & \multicolumn{1}{|c|}{ Accident Condition } \\
\hline $\begin{array}{l}\text { Fissile content of fuel and/or } \\
\text { sludge }\end{array}$ & $(\mathbf{H}-1)$ Criticality $\left(\mathrm{K}_{\text {eff }}>1\right)$ & Nuclear excursion \\
\hline $\begin{array}{l}\text { Chemical reactivity of the } \\
\text { fuel }\end{array}$ & $\begin{array}{l}\text { (H-2) Rapid } \mathrm{U} / \mathrm{H}_{2} \mathrm{O} \text { reaction } \\
(\mathbf{H}-3) \text { Rapid } \mathrm{U} / \mathrm{O}_{2} \text { reaction } \\
(\mathbf{H}-4) \mathrm{Slow} \mathrm{U} / \mathrm{H}_{2} \mathrm{O} \text { reaction } \\
(\mathbf{H}-5) \mathrm{H}_{2} / \mathrm{O}_{2} \text { reaction }\end{array}$ & $\begin{array}{l}\text { MCO overpressurization } \\
\mathrm{H}_{2} \text { detonation/MCO or tube } \\
\text { overpressurization }\end{array}$ \\
\hline Radiolysis & $\begin{array}{l}\text { (H-6) } \mathrm{H}_{2} \mathrm{O} \text { decomposition } \\
(\mathbf{H}-5) \mathrm{H}_{2} / \mathrm{O}_{2} \text { reaction }\end{array}$ & $\begin{array}{l}\text { MCO overpressurization } \\
\mathrm{H}_{2} \text { detonation/MCO or tube } \\
\text { overpressurization }\end{array}$ \\
\hline
\end{tabular}

Table 3-2. Process Control Strategy for Retained Water Inventory Issue. (NOT A CONTROLLED PROJECT REQUIREMENTS DOCUMENT)

\begin{tabular}{||l|l|l|l||}
\hline \multicolumn{1}{|c|}{$\begin{array}{c}\text { Process Element } \\
\text { (Subprojects) }\end{array}$} & Control Parameter & \multicolumn{1}{|c|}{$\begin{array}{c}\text { Process Control } \\
\text { Points }\end{array}$} & \multicolumn{1}{|c||}{ Safety Envelope } \\
\hline Fuel Retrieval & Retained sludge & $<16 \mathrm{~kg}$ & $<277 \mathrm{~kg}^{1}$ \\
\hline Cold Vacuum Drying & $\begin{array}{l}\text { Free water vapor } \\
\text { pressure }\end{array}$ & $\begin{array}{l}<3 \text { torr for } 1 \text { hour } \\
\text { with no pressure rise } \\
\text { followed by heating } \\
\text { to } 75^{\circ} \mathrm{C} . \\
\mathrm{H}_{2} \text { generation rate at } \\
75^{\circ} \mathrm{C} .\end{array}$ & $\begin{array}{l}\text { Same (recycle if } \\
\text { necessary) }\end{array}$ \\
\hline Transportation & Time, temperature & 12 hours, $75^{\circ} \mathrm{C}$ & $25 \mathrm{psig}$ \\
\hline Staging & Pressure & $\begin{array}{l}\text { Vent/purge pressure } \\
\text { build up }\end{array}$ & $25 \mathrm{psig}$ \\
\hline Hot Conditioning/ \\
Storage
\end{tabular}

1 Proposed safety envelope limit related to the MCO radioactive release accident analysis discussed in the June 14, 1996 letter from J.C. Fulton to C.A. Hansen (Fulton 1996b). The currently accepted assumption for $\mathrm{MCO}$ release is a sludge limit of $16 \mathrm{~kg}$ and $150 \mathrm{psig}$. 
Table 3-3. Key Safety-Related Technical Products.

\begin{tabular}{||l|c|c|c|c|c|c|c|c||}
\hline & \multicolumn{7}{|c|}{ Process Step } \\
\cline { 2 - 10 } Technical Product & $\begin{array}{c}\text { Process } \\
\text { Hazard }\end{array}$ & $\begin{array}{c}\text { Fuel } \\
\text { Retrie- } \\
\text { val }\end{array}$ & $\begin{array}{c}\text { Fuel } \\
\text { Trans- } \\
\text { fer }\end{array}$ & $\begin{array}{c}\text { Ship } \\
\text { CVD }\end{array}$ & $\begin{array}{c}\text { Stage } \\
\text { in } \\
\text { CVD } \\
\text { CSB }\end{array}$ & $\begin{array}{c}\text { Store } \\
\text { in } \\
\text { CSB }\end{array}$ \\
\hline Criticality analysis & $\mathrm{H}-1$ & $\mathrm{X}$ & $\mathrm{X}$ & $\mathrm{X}$ & $\mathrm{X}$ & $\mathrm{X}$ & $\mathrm{X}$ & $\mathrm{X}$ \\
\hline Radiolysis analysis & $\mathrm{H}-5, \mathrm{H}-6$ & & & & & $\mathrm{X}$ & & $\mathrm{X}$ \\
\hline $\begin{array}{l}\mathrm{H}_{2} \text { deflagration and } \\
\text { detonation analysis }\end{array}$ & $\mathrm{H}-5$ & & $\mathrm{X}$ & $\mathrm{X}$ & $\mathrm{X}$ & $\mathrm{X}$ & & $\mathrm{X}$ \\
\hline $\mathrm{U} / \mathrm{H}_{2}$ 0 reaction analysis & $\mathrm{H}-2, \mathrm{H}-4$ & & $\mathrm{X}$ & $\mathrm{X}$ & $\mathrm{X}$ & $\mathrm{X}$ & & \\
\hline U/O ${ }_{2}$ reaction analysis & $\mathrm{H}-3$ & & $\mathrm{X}$ & $\mathrm{X}$ & $\mathrm{X}$ & $\mathrm{X}$ & $\mathrm{X}$ & $\mathrm{X}$ \\
\hline $\begin{array}{l}\text { Fuel/sludge drying } \\
\text { curves }\end{array}$ & $\begin{array}{l}\mathrm{H}-2, \mathrm{H}-3 \\
\mathrm{H}-4, \mathrm{H}-5\end{array}$ & & & $\mathrm{X}$ & $\mathrm{X}$ & & $\mathrm{X}$ & $\mathrm{X}$ \\
\hline MCO pressurization & $\begin{array}{c}\mathrm{H}-2 \text { thru } \\
\mathrm{H}-5\end{array}$ & & & $\mathrm{X}$ & $\mathrm{X}$ & & $\mathrm{X}$ & $\mathrm{X}$ \\
\hline $\begin{array}{l}\text { Thermal-hydraulic } \\
\text { analysis }\end{array}$ & $\begin{array}{c}\text { Supports } \\
\text { key } \\
\text { models }\end{array}$ & & $\mathrm{X}$ & $\mathrm{X}$ & $\mathrm{X}$ & $\mathrm{X}$ & $\mathrm{X}$ & $\mathrm{X}$ \\
\hline $\begin{array}{l}\mathrm{O}_{2} \text { consumption/ } \\
\text { Gettering analysis }\end{array}$ & $\mathrm{H}-5$ & & $\mathrm{X}$ & $\mathrm{X}$ & $\mathrm{X}$ & $\mathrm{X}$ & & $\mathrm{X}$ \\
\hline
\end{tabular}

of issues mature. Planned TAP tasks are scheduled and funded. Routine interaction of this program with project engineering staff provides for continuing evolution of TAP activities to meet overall SNF Project and individual subproject requirements. The characterization plan is also relatively mature, and is currently on schedule to support identified information needs and data quality objectives. The data quality objective process has included all known data requirements to support the safety analysis process. Safety analysis planning for the CSB and CVD facility includes resource-loaded schedules. Analysis needs have been defined along with required supporting information needs. Safety analysis planning is in progress for the hot conditioning system, but is less mature than the CSB and CVD work. Process test planning is partially complete at this time. An integrated test strategy has been developed that defines major testing needs. Test planning is expected to be completed in August 1996 in sufficient detail to identify the tests needed to verify the models and assumptions used in the safety analysis. 
Planning details are generally not included in this ISMP; however, a summarized identification of major technical support requirements and their relationship to resolution of the major subproject safety analysis activities and key crosscutting technical assumptions/ uncertainties is provided in the body of the report and the supporting appendices for the purpose of providing management level visibility of the technical integration activities.

The major crosscutting technical support programs such as TAP, characterization, safety analysis, and testing must be integrated so that they meet the subproject technical needs and programmatic (schedule and budget) constraints. Section 3.4 provides a management summary or the crosscutting technical activities that support development and approval of the SNF Project SARs, including related enabling assumptions, modeling, and analyses.

\subsection{TECHNICAL SUPPORT ACTIVITIES TO SUPPORT DESIGN AND SAFETY ANALYSIS (SUMMARY LEVEL)}

Table B-1 in Appendix B provides a summary of the major process design models and analyses, and summarizes the major verification, validation, and testing required to support completion of Project designs. Table B-2 provides a similar summary of safety analyses (i.e., SAR Chapter 3 analyses) and modeling needs for the new facilities being constructed by the SNF Project, along with an identification of data needs and model validation plans.

Appendix A provides a summary description of the SAR Chapter 3 analysis planning and scheduling process. This Appendix includes examples of the detailed data input logic for the CSB MCO pressurization/rupture disk relief analysis and the detailed planning sheet for that analysis. The analysis planning process is used to develop detailed project schedules (including integration logic to assure that technical support, model development, validation and verification, and testing) to support the overall project objectives.

\subsubsection{Characterization and Technology Acquisition Program Support of Safety Analysis}

The SNF Project has developed and is implementing a characterization testing program to determine the physical characteristics and behavior of the $\mathrm{K}$ Basins fuel and sludge (WHC 1995w). The SNF Characterization Program provides necessary data to support the IPS scope and schedules for the SNF and sludge stored in the Hanford $\mathrm{K}$ Basins. The program is driven by the schedule to begin fuel transfer by December 1997. The program is structured for four years (i.e., FY 1995 through FY 1998) and includes in-situ and laboratory examinations of the SNF and sludge in the $\mathrm{K}$ East and $\mathrm{K}$ West Basins.

The SNF Project has also implemented a Technology Acquisition Program (WHC 1995u) to identify and resolve major Project-wide technical issues. The literature searches, studies, model development, and analyses performed through the TAP are closely coordinated with and complement the fuel and sludge characterization activities. 
The intent of the characterization and TAP programs is to provide information required to establish bounding behavior for the fuel and processing methods, and to confirm the acceptability for the transfer of the sludge to the double-shell tanks. Fuel behavior and properties investigated in the laboratory include physical condition, hydride and oxide content, conditioning testing, chemical reaction kinetics, and dry storage behavior. These laboratory examinations are expected to provide the necessary data to establish or confirm fuel conditioning process limits and support safety analysis. Sludge laboratory examinations include measurement of quantity and content, measure of properties for equipment design and recovery processes, tank farm acceptance, simulant development, measurement of corrosion products, and measurements of drying behavior.

Once analytic process models and safety models have been identified, model assumptions must be validated via either literature review or by characterization of the fuel and sludge. Safety modeling has proceeded to a sufficient depth to confirm the initial assumptions in key areas for which further data development was necessary. These areas include chemical reactivity of irradiated N Reactor fuel uranium with atmospheres containing oxygen and water vapor, the drying characteristics of sludge, and sludge compatibility with the waste tanks. Each of these parameters are being evaluated in a phased fashion, tied to specific analyses. The phased SAR submittals will include available technical information and enabling assumptions to support construction authorization decisions. Technical issues and enabling assumptions that serve as the basis for operation of the SNF facilities will be resolved/verified and summarized in formal data reports to be incorporated into the phased SAR submittals. The reporting process will demonstrate that any risks associated with unresolved technical issues or unverified safety assumptions are acceptable until final verification/confirmation prior to submittal of the complete SAR. Major technical topics are summarized below.

Although extensive literature exists for the chemical reactivity of uranium, it consists of two major data sets: unirradiated uranium and irradiated gas-reactor-metallic fuel. Projections based on existing data and knowledge of the fuel form suggest that $\mathrm{N}$ Reactor fuel should show limited reaction, even when exposed to air at elevated temperatures. Since data specific to $\mathrm{N}$ Reactor fuel is currently limited, the project has elected to provide design features that limit air ingress, limiting the potential for release from fuel oxidation. Severe accident analyses (beyond design basis accidents) and some process projections will be based on existing modeling and thermal analysis projections, using conservative assumptions and data from the characterization program. Assumptions for the severe accident and process projections will be verified by confirmatory characterization and testing reports that will be reflected in the phased SAR submittals. The reporting process will demonstrate that any risks associated with unresolved technical issues or unverified safety assumptions are acceptable until final verification/confirmation prior to the final SAR submittal.

Irradiated uranium oxide and sludge drying characteristics are required to support the conclusion that an MCO can be sealed. The current information on the release of bound water from oxidized fuel is limited to data obtained from unirradiated oxides and from basin floor sludge samples containing less than $25 \%$ uranium oxide. These are being supplemented by 
analyses of oxides associated with existing fuel samples and will provide the basis for interim analyses. Final confirmation of the sludge drying characteristics will be reflected in the final characterization data report for sludge drying that will be subsequently reflected in completed SARs. The interim reporting process will demonstrate that any risks associated with unresolved technical issues or unverified safety assumptions associated with the partial submittals are acceptable until final verification/confirmation prior to the final SAR submittal.

Residual basin sludge will be transferred to the waste tanks (pending DOE approval). Sludge compatibility with the waste tanks or with other disposal routes will require further characterization. Preliminary reviews have identified the following issues that will be resolved prior to transfer: chemical reactivity of dry sludge, composition of the sludge, hydraulic properties of the sludge, corrosion rates of uranium particles in $\mathrm{pH}$ ranges characteristic of the waste tanks ( $\mathrm{pH}$ from 6.0 to 12.0), gas generation rate, and gas buildup potential. The schedule for sludge management will be developed further once agreement in principle is obtained between DOE-RL divisions on the transfer of sludge to the waste tanks. Preliminary schedules provide perspective on this activity and the relational logic of supporting characterization activities.

Measurable process parameter (i.e., gas composition, temperatures, and pressures) correlation to the CVD and HCS product criteria will be verified during the process equipment test program and safety analyses (see Appendix B, Tables B-1 and B-2) to demonstrate effective process control. These correlations will verify the bounding chemical reactions, coupled with process monitoring, precision, and macro behavior of the MCO during heat up/cooldown and inert/purge cycles that have been established based upon the TAP and characterization data and safety/design models.

In Appendix B, Tables B-3 (for TAP), B-4 (for characterization), and B-5 (for Process Engineering) provide a list of TAP, characterization, and process engineering reports, that are required to support the SNF Project. These tables also identify the models and safety analyses (by reference to Tables B-1 and B-2) that are supported by these inputs. The reports listed in these three tables represent a planning snapshot in time. They are provided here to illustrate the integration process between the technical support activities and the safety analysis process. Report schedules and scopes can be expected to change as new information is developed.

\subsubsection{Integrated Testing Support of Safety Analysis}

The SNF Project testing ranges from process development testing through acceptance and operational testing. The process development testing supplements the analyses and characterization data provided by engineering analyses and characterization activities. Generic project-level test integration needs are identified in the SNF Project Integrated Test Strategy (WHC 1996h). This strategy will be updated (i.e., scheduled for completion by August 1996) to identify and integrate all SNF Project testing. 
Specific test plans to generate technical data/information for the safety or design bases and models will be prescribed by data quality objectives. These test plans will be designed to supplement the information already supplied by literature search, technology, and design studies/analyses, and characterization efforts.

Acceptance testing and operational testing are facility-specific, providing confirmation of those elements of the design that are unique to the facility as constructed. Acceptance and operational test plans will be developed on a subproject level according to the general guidelines developed in the SNF Project Integrated Test Strategy (WHC 1996h).

Table B-1 lists the major process design confirmation and verification tests that are currently considered sufficient to meet the verification needs of the subprojects. It should be recognized that the current test planning will be more fully developed when the integrated SNF Project test plan scheduled for August 1996 is completed.

\subsubsection{SAR Schedule Interfaces}

Tables 3-4 and 3-5 provide summary-level visibility of how the major technical support activity products (i.e., TAP, characterization, process engineering, and testing) meet the timephased data requirements of the safety analysis for the CSB, CVD, and HCS subprojects. These tables are intended to illustrate how the integration of the technical support activities with preparation of the SNF Project SARs is achieved. They represent a snapshot in time of the planning status. The scheduled completion dates can be expected to evolve as planning and technical understandings mature. The integrated baseline project schedules (not the following tables) should be referenced for up-to-date planning details. 
Table 3-4. Integration of Technical Support Activities with CSB-Phased SAR (3 Sheets).

\begin{tabular}{|c|c|c|c|c|c|c|c|c|}
\hline \multirow{2}{*}{\multicolumn{2}{|c|}{$\begin{array}{c}\text { Phased SAR } \\
\text { Submittals } \\
\text { (See Figure 2-6) }\end{array}$}} & \multirow[b]{2}{*}{ Date $^{1}$} & \multicolumn{6}{|c|}{ Major Technical Support Reports Supporting the CSB SAR } \\
\hline & & & $\begin{array}{l}\text { Characterization Inputs } \\
\text { (Numbered Reports from } \\
\text { Appendix B, Table B-4) }\end{array}$ & \multirow{2}{*}{$\frac{\text { Date }^{\mathrm{i}, 2}}{1 / 96}$} & \multirow{2}{*}{$\begin{array}{l}\text { TAP and Process } \\
\text { Engineering Inputs } \\
\text { (Numbered Reports } \\
\text { from Appendix B, } \\
\text { Table B-3 and B-5) } \\
\text { T4, T5, T13-T15, } \\
\text { T17, T21-T27, T31- } \\
\text { T34, T38, T41, T44, } \\
\text { T46-T49 }\end{array}$} & \multirow{2}{*}{$\frac{\text { Date }^{1,2}}{1 / 96}$} & \multirow[t]{2}{*}{$\begin{array}{l}\text { Test Activities } \\
\text { Issue ModeV } \\
\text { Process Test }\end{array}$} & \multirow[t]{2}{*}{ Date ${ }^{1,2}$} \\
\hline I. & $\begin{array}{l}\text { Substructure } \\
\text { construction } \\
\text { Chapters: } 1,2,3 \text {, } \\
4,6,14,16,17 \\
\text { (Partial) }\end{array}$ & $\begin{array}{l}1 / 96 \\
\text { done }\end{array}$ & $\mathrm{Cl}$ & & & & & \\
\hline II. & $\begin{array}{l}\text { Operating deck } \\
\text { construction } \\
\text { Chapters } 1,6 \text { and } \\
\text { FHA (complete): } \\
\text { Chaps: } 2,3,4 \text {, } \\
16 \text { (Partial) }\end{array}$ & $6 / 96$ & $\mathrm{C} 1, \mathrm{C} 2, \mathrm{C} 6, \mathrm{C} 8, \mathrm{C} 9$ & $6 / 96$ & $\begin{array}{l}\text { T1a, T2, T4, T5, T8- } \\
\text { T11, T13-T18, T21- } \\
\text { T29, T31-T35, T38, } \\
\text { T39, T41-T54, P2, } \\
\text { P5-P8 }\end{array}$ & $6 / 96$ & None & \\
\hline & $\begin{array}{l}\text { Superstructure } \\
\text { Chapters } 2,3,4, \\
16 \text { (Partial) }\end{array}$ & $8 / 96$ & $\begin{array}{l}\mathrm{C} 1, \mathrm{C} 2, \mathrm{C} 6, \mathrm{C} 8, \mathrm{C} 9, \mathrm{C} 14, \mathrm{C} 20 \\
\mathrm{C} 21, \mathrm{C} 24\end{array}$ & $8 / 96$ & $\begin{array}{l}\text { T1a/b, T2, T4-T11, } \\
\text { T13-T19, T21-T29, } \\
\text { T31-T35, T38, T39, } \\
\text { T41-T54, P2, P5-P7 }\end{array}$ & $8 / 96$ & None & \\
\hline & $\begin{array}{l}\text { Chapters } 2,7,8 \text {, } \\
9 \text {, and } 16 \\
\text { (Complete) }\end{array}$ & $10 / 96$ & None & $10 / 96$ & $\begin{array}{l}\text { T1-T11, T13-T19, } \\
\text { T21-T29, T31-T36, } \\
\text { T38, T39, T41-T54, } \\
\text { P1-P9 }\end{array}$ & $10 / 96$ & None & \\
\hline
\end{tabular}


Table 3-4. Integration of Technical Support Activities with CSB-Phased SAR (3 Sheets).

\begin{tabular}{|c|c|c|c|c|c|c|c|}
\hline \multirow[b]{2}{*}{$\begin{array}{c}\text { Phased SAR } \\
\text { Submittals } \\
\text { (See Figure 2-6) }\end{array}$} & \multirow[b]{2}{*}{ Date $^{1}$} & \multicolumn{6}{|c|}{ Major Technical Support Reports Supporting the CSB SAR } \\
\hline & & $\begin{array}{l}\text { Characterization Inputs } \\
\text { (Numbered Reports from } \\
\text { Appendix B, Table B-4) }\end{array}$ & Date $^{1,2}$ & $\begin{array}{l}\text { TAP and Process } \\
\text { Engineering Inputs } \\
\text { (Numbered Reports } \\
\text { from Appendix B, } \\
\text { Table B-3 and B-5) }\end{array}$ & Date $^{1,2}$ & $\begin{array}{l}\text { Test Activities } \\
\text { Issue Model } \\
\text { Process Test }\end{array}$ & Date ${ }^{1,2}$ \\
\hline $\begin{array}{l}\text { V. } \begin{array}{l}\text { Chapters } 3,4 \\
\text { (Complete) }\end{array} \\
\text { Direct Support } \\
\text { Confirmatory }\end{array}$ & $12 / 96$ & $\begin{array}{l}\mathrm{C} 1, \mathrm{C} 2, \mathrm{C} 3, \mathrm{C} 4, \mathrm{C} 6, \mathrm{C} 8, \mathrm{C} 9, \mathrm{C} 10, \\
\mathrm{C} 14, \mathrm{C} 21, \mathrm{C} 22, \mathrm{C} 25 \\
\mathrm{C} 5, \mathrm{C} 7, \mathrm{C} 11, \mathrm{C} 12, \mathrm{C} 13, \mathrm{C} 15, \mathrm{C} 16 \text {, } \\
\mathrm{C} 17, \mathrm{C} 18, \mathrm{C} 19, \mathrm{C} 20, \mathrm{C} 23, \mathrm{C} 24, \\
\mathrm{C} 26, \mathrm{C} 27\end{array}$ & $12 / 96$ & $\begin{array}{l}\text { T1-T1I, T13-T54, P1- } \\
\text { P9 }\end{array}$ & $12 / 96$ & 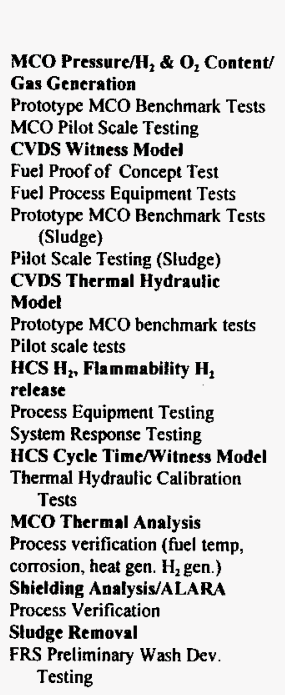 & $\begin{array}{l}12 / 96 \\
12 / 96 \\
1069 \\
10 / 96 \\
10 / 96 \\
10 / 96 \\
\\
10 / 96 \\
10 / 96 \\
12 / 96 \\
12 / 96 \\
12 / 96 \\
10 / 96 \\
10 / 96 \\
7 / 96\end{array}$ \\
\hline $\begin{array}{l}\text { VI. Chapters } 10,11 \text {, } \\
\begin{array}{l}12,13,14,15 \text {, and } \\
17 \text { (Complete) }\end{array}\end{array}$ & $1 / 97$ & None & & None & & None & \\
\hline
\end{tabular}


Table 3-4. Integration of Technical Support Activities with CSB-Phased SAR (3 Sheets).

\begin{tabular}{|c|c|c|c|c|c|c|c|}
\hline \multirow[b]{2}{*}{$\begin{array}{c}\text { Phased SAR } \\
\text { Submittals } \\
\text { (See Figure 2-6) }\end{array}$} & \multirow[b]{2}{*}{ Date $^{1}$} & \multicolumn{6}{|c|}{ Major Technical Support Reports Supporting the CSB SAR } \\
\hline & & $\begin{array}{l}\text { Characterization Inputs } \\
\text { (Numbered Reports from } \\
\text { Appendix B, Table B-4) }\end{array}$ & Date $^{1,2}$ & $\begin{array}{l}\text { TAP and Process } \\
\text { Engineering Inputs } \\
\text { (Numbered Reports } \\
\text { from Appendix B, } \\
\text { Table B-3 and B-5) }\end{array}$ & Date $^{1,2}$ & $\begin{array}{l}\text { Test Activities } \\
\text { Issue Model } \\
\text { Process Test }\end{array}$ & $\dot{D}^{\prime a t e}{ }^{1,2}$ \\
\hline $\begin{array}{l}\text { VII. Chapter 5, } \\
\text { Executive } \\
\text { Summary, and } \\
\text { TSR (Complete) }\end{array}$ & $2 / 97$ & & & & & & \\
\hline Direct Support & & $\begin{array}{l}\mathrm{C} 1, \mathrm{C} 2, \mathrm{C} 3, \mathrm{C} 4, \mathrm{C} 6, \mathrm{C} 7, \mathrm{C} 8, \mathrm{C} 9 \\
\mathrm{C} 10, \mathrm{C} 14, \mathrm{C} 21, \mathrm{C} 22, \mathrm{C} 25\end{array}$ & $2 / 97$ & T1-T54, P1-P9 & $2 / 97$ & $\begin{array}{l}\text { See testing for Chapter } 3 \\
\text { completion above. }\end{array}$ & $\begin{array}{l}\text { See } \\
\text { above }\end{array}$ \\
\hline Confirmatory & & $\begin{array}{l}\mathrm{C} 5, \mathrm{C} 11, \mathrm{C} 12, \mathrm{C} 13, \mathrm{C} 15, \mathrm{C} 16 \\
\mathrm{C} 17, \mathrm{C} 18, \mathrm{C} 19, \mathrm{C} 22, \mathrm{C} 23, \mathrm{C} 26 \\
\mathrm{C} 27\end{array}$ & & & & & \\
\hline $\begin{array}{l}\text { VIII. Complete SAR } \\
\text { to DOE }\end{array}$ & $5 / 97$ & & & & & & \\
\hline Direct Support & & $\begin{array}{l}\mathrm{C} 1, \mathrm{C} 2, \mathrm{C} 3, \mathrm{C} 4, \mathrm{C} 5, \mathrm{C} 6, \mathrm{C} 7, \mathrm{C} 8 \\
\mathrm{C} 9, \mathrm{C} 10, \mathrm{C} 11, \mathrm{C} 12, \mathrm{C} 14, \mathrm{C} 21, \\
\mathrm{C} 22, \mathrm{C} 25\end{array}$ & $5 / 97$ & T1-T54, P1-P9 & $5 / 97$ & $\begin{array}{l}\text { See the test program } \\
\text { submittal for Chapter } 3 \\
\text { completion above. }\end{array}$ & $\begin{array}{l}\text { See } \\
\text { above }\end{array}$ \\
\hline & & $\begin{array}{l}\mathrm{C} 13, \mathrm{C} 15, \mathrm{C} 16, \mathrm{C} 17, \mathrm{C} 18, \mathrm{C} 19 \\
\mathrm{C} 20, \mathrm{C} 23, \mathrm{C} 24, \mathrm{C} 26, \mathrm{C} 27\end{array}$ & $9 / 98$ & & & & \\
\hline
\end{tabular}

1 Required submittal date.

2 Refer to Appendix B Tables for actual submittal dates of individual reports. 
Table 3-5. Integration of Technical Support Activities with CVD- and HCS-Phased SARs and MCO Topical ( 9 Sheets).

\begin{tabular}{|c|c|c|c|c|c|c|c|}
\hline \multirow[b]{2}{*}{$\begin{array}{c}\text { Phased SAR } \\
\text { Submittals }\end{array}$} & \multirow[b]{2}{*}{ Date $^{1}$} & \multicolumn{6}{|c|}{ Major Technical Support Reports Supporting the Phased SARs and MCO Topical } \\
\hline & & $\begin{array}{l}\text { Characterization Inputs } \\
\text { (Numbered Reports from } \\
\text { Appendix B, Table B-4) }\end{array}$ & Date $^{\mathrm{t}, 2}$ & $\begin{array}{l}\text { TAP and Process } \\
\text { Engineering Inputs } \\
\text { (Numbered Reports } \\
\text { from Appendix B, } \\
\text { Table B-3 and B-5) }\end{array}$ & Date $^{1,2}$ & Test Activities & Date $^{1,2}$ \\
\hline \multicolumn{8}{|l|}{$\begin{array}{l}\text { Vacuum drying: } \\
\text { (Figure 2-7) }\end{array}$} \\
\hline $\begin{array}{l}\text { 1. Start of } \\
\text { Construction }\end{array}$ & $8 / 96$ & $\begin{array}{l}\mathrm{C} 1, \mathrm{C} 2, \mathrm{C} 6, \mathrm{C} 8, \mathrm{C} 9, \mathrm{C} 14, \mathrm{C} 21 \text {, } \\
\mathrm{C} 22, \mathrm{C} 25\end{array}$ & $8 / 96$ & $\begin{array}{l}\text { T1a/b, T2, T4-T11, T13- } \\
\text { T19, T21-T29, T31-T35, } \\
\text { T38, T39, T41-T54, P2, } \\
\text { P5-P7 }\end{array}$ & $8 / 96$ & $\begin{array}{l}\text { See the test program } \\
\text { submittal for Chapter } 3 \\
\text { completion above. }\end{array}$ & $\begin{array}{l}\text { See } \\
\text { above }\end{array}$ \\
\hline $\begin{array}{l}\text { II. Fire Hazards } \\
\text { Analysis }\end{array}$ & $9 / 96$ & None & & None & & None & \\
\hline
\end{tabular}


Table 3-5. Integration of Technical Support Activities with CVD- and HCS-Phased SARs and MCO Topical (9 Sheets).

\begin{tabular}{|c|c|c|c|c|c|c|c|}
\hline $\begin{array}{l}\text { Phased SAR } \\
\text { Submittals }\end{array}$ & Date $^{1}$ & \multicolumn{6}{|c|}{ Major Technical Support Reports Supporting the Phased SARs and MCO Topical } \\
\hline $\begin{array}{l}\text { III. Equipment } \\
\text { Installation } \\
\text { Chapters; 2, 3, 4, } \\
16 \text { (Partial); } \\
\text { Chapters 6, 14, } \\
17 \text { (Complete) } \\
\text { Direct Support } \\
\text { Confirmatory }\end{array}$ & 1/97 & $\begin{array}{l}\mathrm{C} 1, \mathrm{C} 2, \mathrm{C} 3, \mathrm{C} 4, \mathrm{C} 6, \mathrm{C} 7, \mathrm{C} 8, \mathrm{C} 9, \\
\mathrm{C} 10, \mathrm{C} 14, \mathrm{C} 21, \mathrm{C} 22, \mathrm{C} 25 \\
\mathrm{C} 5, \mathrm{C} 11, \mathrm{C} 12, \mathrm{C} 13, \mathrm{C} 15, \mathrm{C} 16 \\
\mathrm{C} 17, \mathrm{C} 18, \mathrm{C} 19, \mathrm{C} 20, \mathrm{C} 21, \mathrm{C} 24, \\
\mathrm{C} 25, \mathrm{C} 26, \mathrm{C} 27\end{array}$ & $1 / 97$ & T1-T54, P1-P9 & $1 / 97$ & 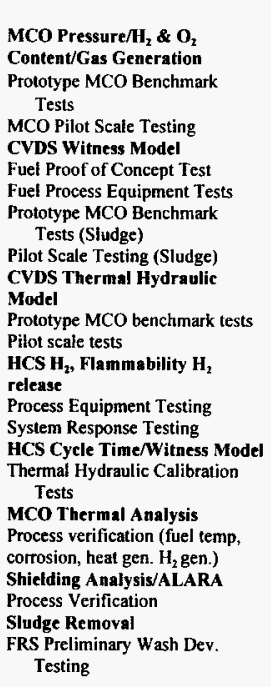 & $\begin{array}{l}12 / 96 \\
12 / 96 \\
10 / 96 \\
10 / 96 \\
10 / 96 \\
10 / 96 \\
\\
10 / 96 \\
10 / 96 \\
12 / 96 \\
12 / 96 \\
12 / 96 \\
10 / 96 \\
10 / 96 \\
\\
7 / 96\end{array}$ \\
\hline
\end{tabular}


Table 3-5. Integration of Technical Support Activities with CVD- and HCS-Phased SARs and MCO Topical (9 Sheets).

\begin{tabular}{|c|c|c|c|c|c|c|c|c|}
\hline \multirow{2}{*}{\multicolumn{2}{|c|}{$\begin{array}{l}\text { Phased SAR } \\
\text { Submittals }\end{array}$}} & \multirow[b]{2}{*}{ Date $^{1}$} & \multicolumn{6}{|c|}{ Major Technical Support Reports Supporting the Phased SARs and MCO Topical } \\
\hline & & & $\begin{array}{l}\text { Characterization Inputs } \\
\text { (Numbered Reports from } \\
\text { Appendix B, Table B-4) }\end{array}$ & Date $^{1,2}$ & $\begin{array}{l}\text { TAP and Process } \\
\text { Engineering Inputs } \\
\text { (Numbered Reports } \\
\text { from Appendix B, } \\
\text { Table B-3 and B-5) }\end{array}$ & Date $^{1,2}$ & Test Activities & Date $^{1,2}$ \\
\hline IV. & $\begin{array}{l}\text { Complete } \\
\text { Chapters 2, 7,8, } \\
9,16\end{array}$ & $2 / 97$ & & & & & & \\
\hline & $\begin{array}{l}\text { Direct Support } \\
\text { Confirmatory }\end{array}$ & & $\begin{array}{l}\mathrm{C} 1, \mathrm{C} 2, \mathrm{C} 3, \mathrm{C} 4, \mathrm{C} 6, \mathrm{C} 7, \mathrm{C} 8, \mathrm{C} 9, \\
\mathrm{C} 10, \mathrm{C} 14, \mathrm{C} 21, \mathrm{C} 22, \mathrm{C} 25 \\
\mathrm{C} 5, \mathrm{C} 11, \mathrm{C} 12, \mathrm{C} 13, \mathrm{C} 15, \mathrm{C} 16 \\
\mathrm{C} 17, \mathrm{C} 18, \mathrm{C} 19, \mathrm{C} 20, \mathrm{C} 23, \mathrm{C} 24, \\
\mathrm{C} 26, \mathrm{C} 27\end{array}$ & $\begin{array}{l}2 / 97 \\
9 / 98\end{array}$ & T1-T54, P1-P9 & $1 / 97$ & $\begin{array}{l}\text { See the test program } \\
\text { submittal for process } \\
\text { equipment installation } \\
\text { above. }\end{array}$ & $\begin{array}{l}\text { See } \\
\text { above }\end{array}$ \\
\hline VI. & $\begin{array}{l}\text { Complete } \\
\text { Chapters } 10,11 \text {, } \\
12,13,14,15 \text {, } \\
\text { and } 17\end{array}$ & $4 / 97$ & None & & None & & None & \\
\hline
\end{tabular}


Table 3-5. Integration of Technical Support Activities with CVD- and HCS-Phased SARs and MCO Topical (9 Sheets).

\begin{tabular}{|c|c|c|c|c|c|c|c|}
\hline \multirow[b]{2}{*}{$\begin{array}{l}\text { Phased SAR } \\
\text { Submittals }\end{array}$} & \multirow[b]{2}{*}{ Date $^{1}$} & \multicolumn{6}{|c|}{ Major Technical Support Reports Supporting the Phased SARs and MCO Topical } \\
\hline & & $\begin{array}{l}\text { Characterization Inputs } \\
\text { (Numbered Reports from } \\
\text { Appendix B, Table B-4) }\end{array}$ & Date $^{1,2}$ & $\begin{array}{l}\text { TAP and Process } \\
\text { Engineering Inputs } \\
\text { (Numbered Reports } \\
\text { from Appendix B, } \\
\text { Table B-3 and B-5) }\end{array}$ & Date ${ }^{1,2}$ & Test Activities & Date $^{1,2}$ \\
\hline $\begin{array}{l}\text { VII. Complete } \\
\text { Chapter 5, } \\
\text { Exec. Summary, } \\
\text { and TSR } \\
\text { Document. } \\
\text { Direct Support } \\
\\
\text { Confirmatory }\end{array}$ & $4 / 97$ & $\begin{array}{l}\mathrm{C} 1, \mathrm{C} 2, \mathrm{C} 3, \mathrm{C} 4, \mathrm{C} 5, \mathrm{C} 6, \mathrm{C} 7, \mathrm{C} 8, \\
\mathrm{C} 9, \mathrm{C} 10, \mathrm{C} 11, \mathrm{Cl} 14, \mathrm{C} 21, \mathrm{C} 22, \\
\mathrm{C} 25 \\
\mathrm{C} 12, \mathrm{C} 13, \mathrm{C} 15, \mathrm{C} 16, \mathrm{C} 17, \mathrm{C} 18, \\
\mathrm{C} 19, \mathrm{C} 20, \mathrm{C} 23, \mathrm{C} 24, \mathrm{C} 26, \mathrm{C} 27\end{array}$ & $\begin{array}{l}4 / 97 \\
9 / 98\end{array}$ & T1-T54, P1-P9 & $1 / 97$ & $\begin{array}{l}\text { See the test program } \\
\text { submittal for process } \\
\text { equipment installation } \\
\text { above. }\end{array}$ & $\begin{array}{l}\text { See } \\
\text { above }\end{array}$ \\
\hline $\begin{array}{l}\text { VIII. Complete SAR } \\
\text { to DOE }\end{array}$ & $5 / 97$ & & & & & & \\
\hline $\begin{array}{l}\text { Direct Support } \\
\text { Confirmatory }\end{array}$ & & $\begin{array}{l}\mathrm{C} 1, \mathrm{C} 2, \mathrm{C} 3, \mathrm{C} 4, \mathrm{C} 5, \mathrm{C} 6, \mathrm{C} 7, \mathrm{C} 8, \\
\mathrm{C} 9, \mathrm{C} 10, \mathrm{C} 11, \mathrm{C} 12, \mathrm{C} 14, \mathrm{C} 21, \\
\mathrm{C} 22, \mathrm{C} 25 \\
\mathrm{C} 12, \mathrm{C} 13, \mathrm{C} 15, \mathrm{C} 16, \mathrm{C} 17, \mathrm{C} 18, \\
\mathrm{C} 19, \mathrm{C} 20, \mathrm{C} 23, \mathrm{C} 24, \mathrm{C} 26, \mathrm{C} 27\end{array}$ & $9 / 98$ & T1-T54, P1-P9 & $1 / 97$ & $\begin{array}{l}\text { See the test program } \\
\text { submittal for process } \\
\text { equipment installation } \\
\text { above. }\end{array}$ & $\begin{array}{l}\text { See } \\
\text { above }\end{array}$ \\
\hline
\end{tabular}


Table 3-5. Integration of Technical Support Activities with CVD- and HCS-Phased SARs and MCO Topical (9 Sheets).

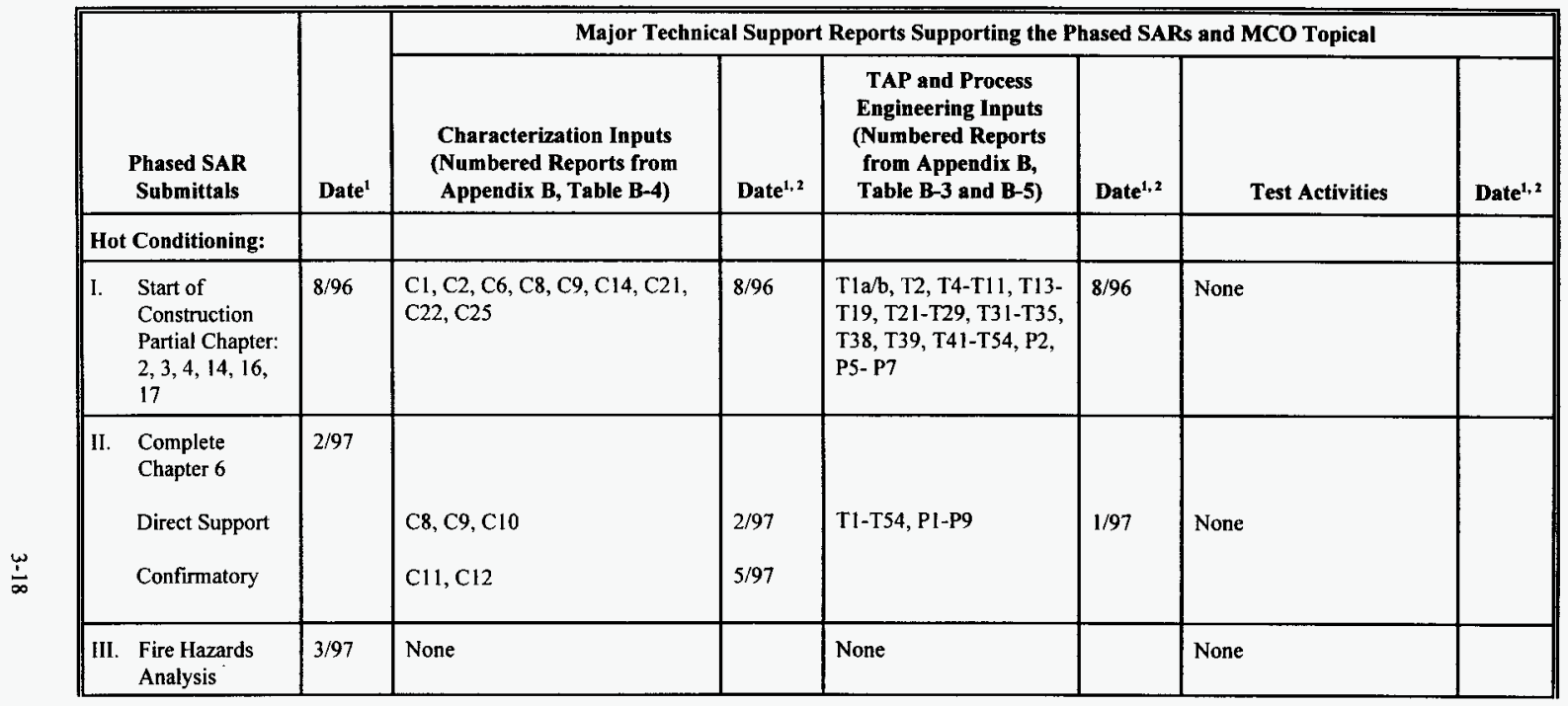


Table 3-5. Integration of Technical Support Activities with CVD- and HCS-Phased SARs and MCO Topical (9 Sheets).

\begin{tabular}{|c|c|c|c|c|c|c|c|c|}
\hline \multirow{2}{*}{\multicolumn{2}{|c|}{$\begin{array}{l}\text { Phased SAR } \\
\text { Submittals }\end{array}$}} & \multirow[b]{2}{*}{ Date' } & \multicolumn{6}{|c|}{ Major Technical Support Reports Supporting the Phased SARs and MCO Topical } \\
\hline & & & $\begin{array}{l}\text { Characterization Inputs } \\
\text { (Numbered Reports from } \\
\text { Appendix B, Table B-4) }\end{array}$ & Date $^{1,2}$ & $\begin{array}{l}\text { TAP and Process } \\
\text { Engineering Inputs } \\
\text { (Numbered Reports } \\
\text { from Appendix B, } \\
\text { Table B-3 and B-5) }\end{array}$ & Date $^{1,2}$ & Test Activities & Date $^{1,2}$ \\
\hline IV. & $\begin{array}{l}\text { Equipment } \\
\text { Installation } \\
\text { Partial Chapters } \\
2,3,4,16,17 \\
\text { Direct Support } \\
\text { Confirmatory }\end{array}$ & $3 / 97$ & $\begin{array}{l}\mathrm{C} 1, \mathrm{C} 2, \mathrm{C} 3, \mathrm{C} 4, \mathrm{C} 5, \mathrm{C} 6, \mathrm{C} 7, \mathrm{C} 8, \\
\mathrm{C} 9, \mathrm{C} 10, \mathrm{C} 14, \mathrm{C} 21, \mathrm{C} 22, \mathrm{C} 25 \\
\mathrm{C} 11, \mathrm{C} 12, \mathrm{C} 13, \mathrm{C} 15, \mathrm{C} 16, \mathrm{C} 17, \\
\mathrm{C} 18, \mathrm{C} 19, \mathrm{C} 20, \mathrm{C} 23, \mathrm{C} 24, \mathrm{C} 26, \\
\mathrm{C} 27\end{array}$ & $\begin{array}{l}3 / 97 \\
9 / 98\end{array}$ & T1-T54, PI-P9 & 1/97 & $\begin{array}{l}\text { MCO Pressure/H, \& } \mathbf{O}_{2} \\
\text { Content/Gas Generation } \\
\text { Prototype MCO Benchmark } \\
\text { Tests } \\
\text { MCO Pilot Scale Testing } \\
\text { CVDS Witness Model } \\
\text { Fuel Proof of Concept Test } \\
\text { Fuel Process Equipment Tests } \\
\text { Prototype MCO Benchmark } \\
\text { Tesss (Sludge) } \\
\text { Pilot Scale Testing (Sludge) } \\
\text { CVDS Thermal Hydraulic } \\
\text { Model } \\
\text { Prototype MCO benchmark tests } \\
\text { Pilot scale tests } \\
\text { HCS H } \\
\text { relesse Flammability, } \mathbf{H}_{2} \\
\text { Process Equipment Testing } \\
\text { System Response Testing } \\
\text { HCS Cycle Time/Witness } \\
\text { Model } \\
\text { Thermal Hydraulic Calibration } \\
\text { Tests } \\
\text { MCO Thermal Analysis } \\
\text { Process verification (fuel temp. } \\
\text { corrosion, heat gen. } \text { H }_{2} \text { gen). } \\
\text { Shielding Analysis/ALARA } \\
\text { Process Verification } \\
\text { Sludge Removal } \\
\text { FRS Preliminary Wash Dev. } \\
\text { Testing }\end{array}$ & $\begin{array}{l}12 / 96 \\
12 / 96 \\
10 / 96 \\
10 / 96 \\
10 / 96 \\
10 / 96 \\
\\
10 / 96 \\
10 / 96 \\
12 / 96 \\
12 / 96 \\
\\
12 / 96 \\
10 / 96 \\
10 / 96 \\
7 / 96\end{array}$ \\
\hline V. & $\begin{array}{l}\text { Complete } \\
\text { Chapters } 2 \text {, } \\
7,8,9,16\end{array}$ & $6 / 97$ & None & & None & & None & \\
\hline
\end{tabular}


Table 3-5. Integration of Technical Support Activities with CVD- and HCS-Phased SARs and MCO Topical (9 Sheets).

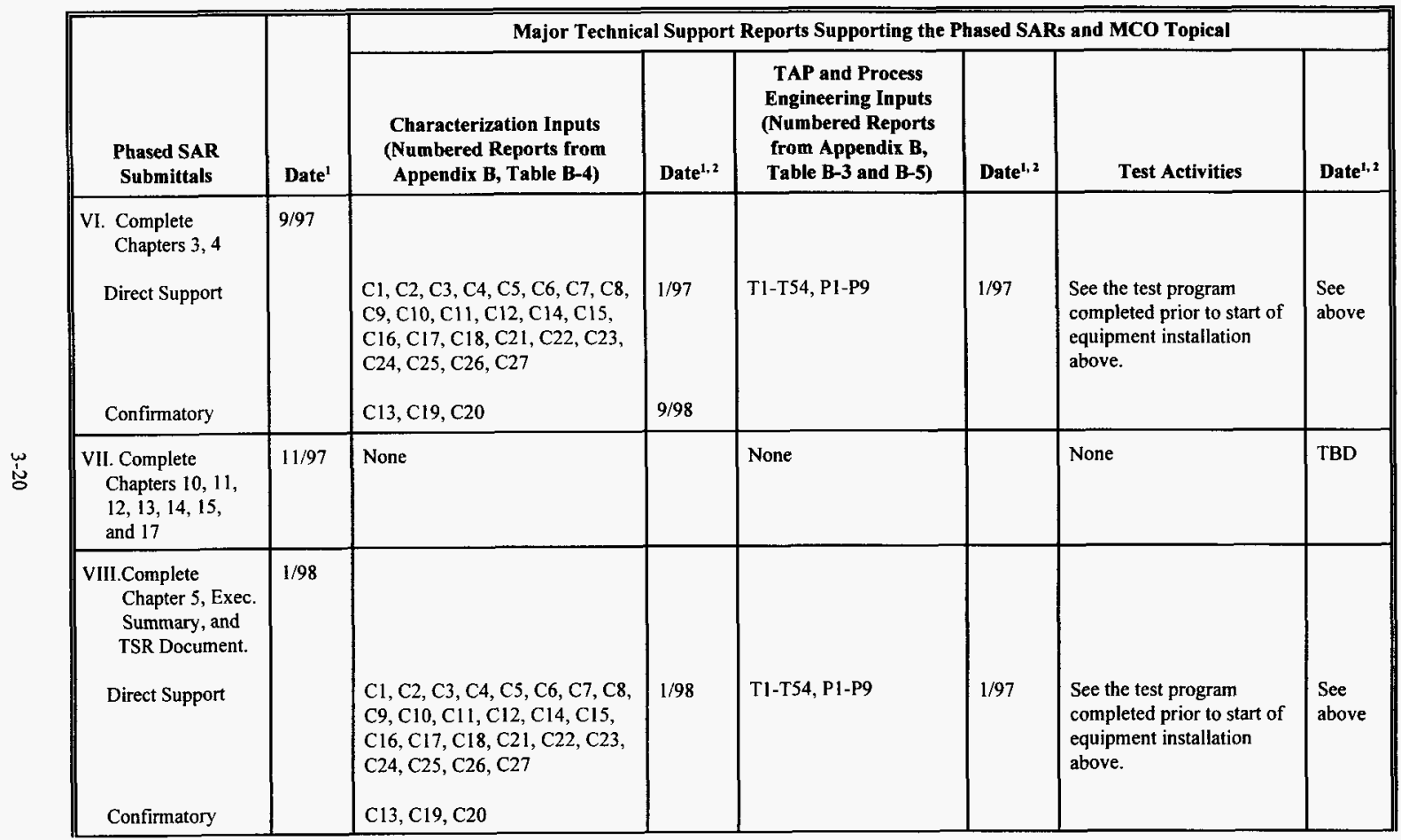


Table 3-5. Integration of Technical Support Activities with CVD- and HCS-Phased SARs and MCO Topical (9 Sheets).

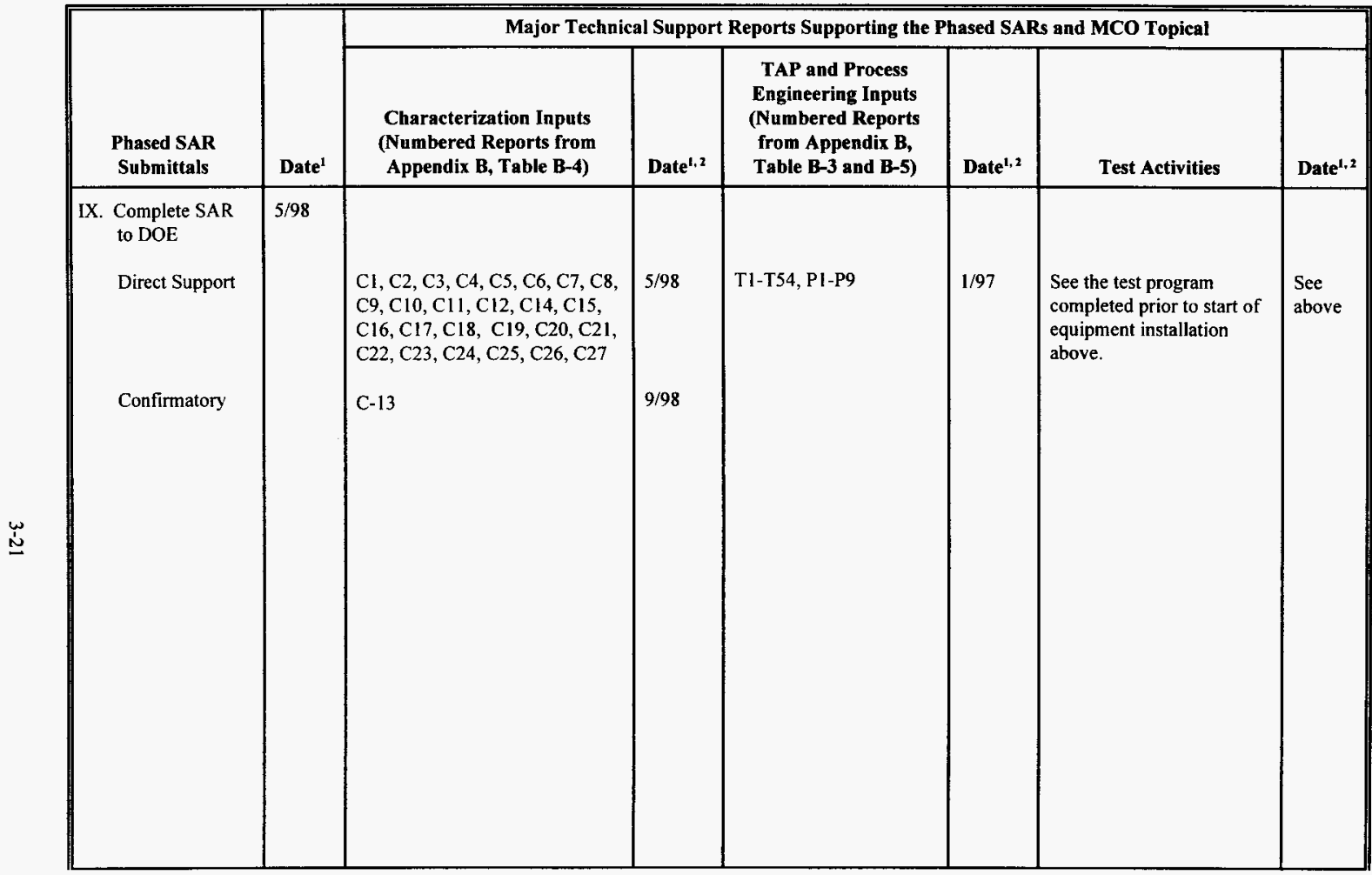


Table 3-5. Integration of Technical Support Activities with CVD- and HCS-Phased SARs and MCO Topical (9 Sheets).

\begin{tabular}{|c|c|c|c|c|c|c|c|}
\hline \multirow[b]{2}{*}{$\begin{array}{l}\text { Phased SAR } \\
\text { Submittals }\end{array}$} & \multirow[b]{2}{*}{ Date' } & \multicolumn{6}{|c|}{ Major Technical Support Reports Supporting the Phased SARs and MCO Topical } \\
\hline & & $\begin{array}{l}\text { Characterization Inputs } \\
\text { (Numbered Reports from } \\
\text { Appendix B, Table B-4) }\end{array}$ & Date $^{1,2}$ & $\begin{array}{l}\text { TAP and Process } \\
\text { Engineering Inputs } \\
\text { (Numbered Reports } \\
\text { from APpendix B, } \\
\text { Table B-3 and B-5) }\end{array}$ & Date $^{1,2}$ & Test Activities & Date $^{1,2}$ \\
\hline \multicolumn{8}{|l|}{ MCO Topical: } \\
\hline
\end{tabular}

${ }^{1}$ Required submittal date.

${ }^{2}$ Refer to Appendix B Tables for actual submittal dates of individual reports. 


\subsection{SNF PROJECT ENVIRONMENTAL DOCUMENTATION}

The SNF Project environmental documentation forms a key portion of the overall authorization basis for approval to start construction and operations of the SNF subprojects. The environmental documentation includes the environmental impact statement and other documents required under the National Environmental Policy Act and implementing DOE regulations, 10 CFR 1021, and facility-specific environmental permits. The environmental documentation for the SNF Project is discussed in detail in the sections that follow.

\subsection{NEPA Documentation}

The Integrated Process Strategy (WHC 1995b) is being implemented based on completed National Environmental Policy Act (NEPA) reviews.

- The Environmental Impact Statement, Management of Spent Nuclear Fuel from the $K$ Basins at the Hanford Site, Richland, Washington, DOE/EIS-0245F (DOE 1996d), which enabled fuel, sludge and debris removal, and the acquisition and operation of systems to achieve interim storage of the fuel (i.e., SNF Project activities for relocating the SNF to the CSB and conditioning the fuel, as required, for interim dry storage.)

- Categorical exclusions and environmental assessments prepared for interim actions in the $\mathrm{K}$ Basins that were performed prior to issuance of the $\mathrm{K}$ Basins SNF Environmental Impact Statement (EIS) Record of Decision (ROD) (DOE 1996e); such as, pilot and development activities, SNF characterization, and facility modifications to maintain safe operations and prepare for fuel relocation.

Pending DOE-RL approval of a Contractor recommendation for management of the other SNF at the CSB and a contiguously located 200 Area ISA, a NEPA review will be initiated for other SNF management at the Hanford site. The NEPA review will likely be satisfied through completion of an Environmental Assessment.

NEPA Environmental Impact Statement and Record of Decision. DOE decided to implement the preferred alternative evaluated in the Final Environmental Impact Statement (FEIS) with two modifications, and that decision was documented in a ROD issued March 4, 1996 (DOE 1996e). The preferred alternative consists of removing the SNF from the basins and vacuum drying, conditioning, and sealing the SNF in inert gas-filled canisters for dry vault storage for up to 75 years in a new facility to be built at Hanford, pending decisions on ultimate disposition.

The K Basins will continue to be operated until fuel, sludge, and debris removal and cleanup activities are completed and the facility is transitioned to D\&D. The preferred alternative 
also includes transfer of the basin sludge to Hanford's double-shell tanks for management, disposal of non-SNF basin debris in a low-level burial ground at the Hanford site, disposition of the basin water, and deactivation of the basins pending decommissioning.

The two modifications in the ROD are with respect to management of the sludge and the timing of placement of the SNF into the transportation casks. The modification for management of the sludge is that if it is not possible to put the sludge into the double-shell tanks, the sludge will either continue to be managed as SNF, or disposed of as solid waste. The modification regarding placement of the SNF into the transportation casks would reduce the radiation exposure to the workers by placing the MCOs inside the transportation casks before the SNF is loaded in the MCOs, instead of loading the SNF into the MCOs prior to placing them inside the transportation casks.

\subsection{Environmental Regulatory Requirements and Permitting}

In addition to the NEPA and safety documentation, permits will be required for anticipated air emissions and the liquid effluent generated. In general, environmental permits constrain the start of construction or operation. Where applicable, Notices of Construction (NOCs) must be submitted to the State of Washington Department of Health (DOH), the State of Washington Department of Ecology (Ecology) and to the U.S. Environmental Protection Agency (EPA) to address potential air emissions, prior to beginning modifications that could result in increased air emissions to the $\mathrm{K}$ Basins or to construction of new facilities such as the CVD, $\mathrm{CSB}$, and HCS.

A regulatory path for disposition of basin sludge will be negotiated with Ecology and the EPA under the Tri-Party Agreement, and permit applications will be prepared and submitted to Ecology and the EPA for any new or modified industrial wastewater disposal permits that might be required. Permit applications will be submitted to the DOH for installation of domestic wastewater septic systems, as required.

Cultural. historical, and biological reviews of the project will be made and appropriate registrations or consultations will be conducted with the State Historic Preservation Office, the U.S. Fish and Wildlife Service, and any other affected agency.

The regulatory agencies will be involved early in the permit planning process to minimize the potential for delays and to assure that the necessary equipment/facility design and performance data are included in the NOCs and permit applications. Planned activities and milestones for obtaining the permits required to support the SNF Project facilities and activities are included in the Integrated Schedule. 


\subsection{Identification of Required Spent Nuclear Fuel Project Environmental Permits}

The matrix shown in Table 4-1 portrays the current scope of environmental regulatory agency permits and approvals that have been identified as necessary for the SNF Project subprojects. The indicated scope could change as design of the subprojects progresses or if the regulatory agencies do not agree with this interpretation of what permits and approvals are required. The matrix identifies only the project-specific permits and approvals that are expected to be required, as distinct from the environmental rules, regulations, and requirements that each subproject must follow to obtain the permits. Also not listed are the routine in-house procedural permits and approvals that are required of all projects (e.g., excavation permits). 
Table 4-1. Matrix of Environmental Documents Required for SNF Project Subprojects (2 Sheets).

\begin{tabular}{|c|c|c|c|c|c|c|c|c|c|c|c|}
\hline PERMIT/APPROVAL & AUTHORITY & CSB & CVD & HCS & KFP & $\begin{array}{l}\text { KW } \\
\text { IWTS }\end{array}$ & $\begin{array}{c}\text { KE } \\
\text { IWTS }\end{array}$ & DRS & $\begin{array}{l}\mathbf{K W} \\
\mathbf{F R}\end{array}$ & $\begin{array}{l}\mathbf{K E} \\
\mathbf{F R}\end{array}$ & SRS \\
\hline National Environmental Policy Act & 10 CFR 1021 & $Y^{1}$ & $Y^{\prime}$ & $Y^{1}$ & $\mathrm{Y}^{2}$ & $Y^{\prime}$ & $Y^{\prime}$ & $\mathrm{Y}^{2}$ & $Y^{\prime}$ & $\mathbf{Y}^{1}$ & $Y^{1,3}$ \\
\hline State Environmental Policy Act & WAC $197-11$ & $\mathrm{~N}^{4}$ & $\mathrm{~N}^{4}$ & $\mathrm{~N}^{4}$ & $\mathrm{~N}^{4}$ & $\mathrm{~N}^{4}$ & $\mathrm{~N}^{4}$ & $\mathrm{~N}^{4}$ & $\mathrm{~N}^{4}$ & $\mathrm{~N}^{4}$ & $\mathrm{~N}^{4}$ \\
\hline $\begin{array}{l}\text { Washington State Department of } \\
\text { Health (DOH) Phase I Rad Air } \\
\text { Notice of Construction (NOC) }\end{array}$ & WAC $246-247$ & $\mathrm{Y}^{5}$ & $\mathrm{Y}$ & $\mathrm{Y}$ & $\mathbf{Y}^{6}$ & $\mathbf{Y}^{7}$ & $\mathrm{Y}^{7}$ & $\mathrm{Y}^{7}$ & $\mathbf{Y}^{7}$ & $\mathrm{Y}^{7}$ & $\mathrm{Y}^{8}$ \\
\hline DOH Phase II Rad Air NOC & $" \quad "$ & $Y$ & $\mathrm{Y}$ & $\mathrm{Y}$ & $\mathrm{N}$ & $\mathrm{N}$ & $\mathbf{N}$ & $\mathbf{N}$ & $\mathbf{N}$ & $\mathrm{N}$ & $\mathbf{N}$ \\
\hline $\begin{array}{l}\text { Washington State Department of } \\
\text { Ecology Phase I Air Toxic Air } \\
\text { Pollutants NOC }\end{array}$ & WAC $173-460$ & $\mathrm{~N}^{9}$ & $\mathbf{Y}$ & $\mathbf{Y}$ & $\mathbf{N}$ & $\mathbf{Y}^{10}$ & $Y^{10}$ & $\mathbf{N}$ & $\mathbf{N}$ & $\mathbf{N}$ & $\mathrm{Y}^{10}$ \\
\hline $\begin{array}{l}\text { Washington State Department of } \\
\text { Ecology Phase II Air Toxic Air } \\
\text { Pollutants NOC }\end{array}$ & $" \quad "$ & $\mathrm{~N}^{9}$ & $\mathrm{Y}$ & $\mathrm{Y}$ & $\mathrm{N}$ & $\mathrm{N}$ & $\mathbf{N}$ & $\mathbf{N}$ & $\mathbf{N}$ & $\mathrm{N}$ & $\mathbf{N}$ \\
\hline $\begin{array}{l}\text { U.S. Environmental Protection } \\
\text { Agency (EPA) NESHAPS Rad Air } \\
\text { NOC }\end{array}$ & 40 CFR $61, \mathrm{H}$ & $Y^{11}$ & $\mathbf{Y}$ & $\mathrm{Y}$ & $\mathbf{Y}$ & $\mathrm{Y}$ & $\mathbf{Y}$ & $\mathbf{Y}$ & $\mathrm{Y}$ & $\mathrm{Y}$ & $\mathbf{Y}$ \\
\hline Air Operating Permit & WAC 173-401 & $\mathrm{Y}$ & $\mathrm{Y}$ & $\mathrm{Y}$ & $\mathrm{Y}$ & $\mathrm{Y}$ & $\mathbf{Y}$ & $\mathrm{Y}$ & $\mathbf{Y}$ & $\mathrm{Y}$ & $\mathbf{Y}$ \\
\hline Ecology 216 Wastewater Permit & WAC 173-216 & $\mathbf{N}^{12}$ & $\mathrm{~N}^{12}$ & $\mathrm{~N}^{12}$ & $\mathrm{~N}$ & $\mathrm{~N}$ & $\mathbf{N}$ & $\mathbf{N}$ & $\mathbf{N}$ & $\mathrm{N}$ & $\mathbf{N}$ \\
\hline DOH Sanitary Waste Permit & WAC 246-272 & $\mathbf{N}^{13}$ & $\mathrm{~N}^{13}$ & $\mathrm{~N}^{13}$ & $\mathbf{Y}$ & $\mathrm{N}$ & $\mathbf{N}$ & $\mathbf{N}$ & $\mathbf{N}$ & $\mathbf{N}$ & $\mathbf{N}$ \\
\hline $\begin{array}{l}\text { Ecology Dangerous Waste, } \\
\text { Resource Conservation and } \\
\text { Recovery Act Permit }\end{array}$ & $\begin{array}{l}\text { WAC } 173-303 \\
40 \text { CFR } 264 \\
265,270\end{array}$ & $N^{14}$ & $\mathbf{N}^{14}$ & $\mathrm{~N}^{14}$ & $\mathbf{N}$ & $\mathbf{N}$ & $\mathbf{N}$ & $\mathrm{N}$ & $\mathrm{N}$ & $\mathbf{N}$ & $\mathrm{N}$ \\
\hline $\begin{array}{l}\text { Cultural/Historical Resource } \\
\text { Review }\end{array}$ & 36 CFR 800 & $Y^{15}$ & $Y^{16}$ & $\mathbf{Y}$ & $\mathbf{Y}^{17}$ & $\mathbf{Y}^{17}$ & $Y^{17}$ & $\mathrm{Y}$ & $Y^{17}$ & $\mathbf{Y}^{17}$ & $\mathrm{~N}$ \\
\hline $\begin{array}{r}\text { Legend: CSB } \\
\text { CVD } \\
\text { DRS } \\
\text { HCS } \\
\text { KFP }\end{array}$ & $\begin{array}{l}\text { dilding } \\
\text { ng } \\
\text { ystem } \\
\text { ystem } \\
\text { rojects } \\
\text { hers) }\end{array}$ & $\begin{array}{l}\text { E FR } \\
\text { E IWTS } \\
\text { W FR } \\
\text { W IWTS } \\
\text { RS }\end{array}$ & $\begin{array}{l}\text { K East } \\
\text { K East } \\
\text { K West } \\
\text { K West } \\
\text { Sludge }\end{array}$ & $\begin{array}{l}\text { el Retri } \\
\text { ater Tre } \\
\text { uel Retri } \\
\text { Vater Tre } \\
\text { emoval }\end{array}$ & $\begin{array}{l}\text { al } \\
\text { nent Sys } \\
\text { zal } \\
\text { ment Sy } \\
\text { stem }\end{array}$ & & & & & & \\
\hline
\end{tabular}


Table 4-1. Matrix of Environmental Documents Required for SNF Project Subprojects (2 Sheets).

\begin{tabular}{|c|c|c|c|c|c|c|c|c|c|c|c|}
\hline PERMIT/APPROVAL & AUTHORITY & CSB & CVD & HCS & KFP & $\begin{array}{l}\text { KW } \\
\text { IWTS }\end{array}$ & $\begin{array}{l}\text { KE } \\
\text { IWTS }\end{array}$ & DRS & $\begin{array}{r}\text { KW } \\
\text { FR } \\
\end{array}$ & $\begin{array}{l}\text { KE } \\
\text { FR }\end{array}$ & SRS \\
\hline Biological Resource Review & $\begin{array}{l}10 \text { CFR } 1021 \\
50 \text { CFR } 402.6 \\
\text { DOE } 5484.1\end{array}$ & $Y^{18}$ & $\mathrm{Y}$ & $\mathrm{Y}$ & $\mathrm{Y}$ & $\mathrm{Y}$ & $\mathrm{Y}$ & $\mathrm{N}$ & $\mathrm{N}$ & $\mathrm{N}$ & $\mathrm{N}$ \\
\hline $\begin{array}{l}\text { Baseline Environmental } \\
\text { Monitoring }\end{array}$ & DOE 5400.5 & $\mathrm{Y}^{19}$ & $\mathrm{Y}$ & $\mathrm{Y}$ & $\mathrm{Y}^{20}$ & $\mathrm{Y}^{20}$ & $\mathrm{Y}^{20}$ & $\mathrm{~N}$ & $\mathrm{Y}^{20}$ & $\mathrm{Y}^{20}$ & $Y^{20}$ \\
\hline
\end{tabular}

Legend: CSB Canister Storage Building

KE FR K East Fuel Retrieval

CVD Cold Vacuum Drying

DRS Debris Removal System

KE IWTS K East Water Treatment System

HCS Hot Conditioning System

KFP K Basins Facility Projects

KW FR K West Fuel Retrieval

KW IWTS K West Water Treatment System

(Projects 405 and others)

SRS Sludge Removal System

Notes: I. The Environmental Impact Statement and Record of Decision have been completed.

2. NEPA documentation is in the form of Environmental Assessments or Information Bulletin/Categorical Exclusions.

3. A draft of the TWRS Environmental Impact Statement is out for public review and comment. Acceptance of the K Basins sludge will have to be added to the final EIS.

4. Washington State Department of Ecology can accept NEPA in lieu of SEPA. Closure with Ecology required.

5. DOH approved the Phase I NOC for the CSB on January 11, 1996.

6. The projects that make up "Essential Systems Upgrades" are considered to be minor in nature and fall into the category of routine operations/maintenance.

7. Phased permitting is not planned.

8. NOC to DOH will be a revision of the K East Water Treatment System.

9. Washington State Department of Ecology Toxic Air Pollutants permit not required for the CSB because none are expected to be emitted.

10. Based on limited process information and the presence of PCBs and heavy metals in $105 \mathrm{~K}$ East Basin sludge, this permit is identified at this time pending further evaluation.

11. EPA approved the NOC for the CSB on March 5, 1996.

12. Permit not required if non-contact wastewater streams are not disposed into the ground through an engineered structure or if no contact wastewater will be disposed to the ground.

13. Permit not required if no sanitary waste discharge or if temporary sanitary facilities are used. Permit application in process for CVD facility.

14. Assumes the fuel and basin water processed at the facilities are not state dangerous waste.

15. Complete for CSB (Pacific Northwest National Laboratory letter dated January 31, 1996).

16. Completed for CVD facility.

17. Cultural/historical resource reviews will be conducted based on planned excavation activities and/or modifications to existing facilities.

18. Complete for CSB (Pacific Northwest National Laboratory letter dated February 15, 1996).

19. Baseline monitoring has been started for the CSB.

20. Baseline monitoring requirements are believed to have already been satisfied; justification being transmitted separately to DOE-RL. 
WHC-SD-SNF-PLN-012

Rev. 2

This page intentionally left blank. 


\subsection{REFERENCES}

10 CFR 50, Domestic Licensing of Production and Utilization Facilities.

10 CFR 72, Licensing Requirements for the Independent Storage of Spent Nuclear Fuel and High-level Radioactive Waste.

10 CFR 1021, Compliance with the National Environmental Policy Act.

36 CFR 800, Protection of Archaeological and Cultural Properties.

40 CFR 61, National Emission Standards for Hazardous Air Pollutants

40 CFR 264, Standards for Owners and Operators of Hazardous Waste Treatment, Storage, and Disposal Facilities.

40 CFR 265, Interim Status Standards for Owners and Operators of Hazardous Waste Treatment, Storage, and Disposal Facilities.

40 CFR 270, The Hazardous Waste Permit Program.

Conway, J. T., 1990, Defense Nuclear Facility Safety Board Recommendation 90-2, (letter to James D. Watkins, March 8, U.S. Department of Energy, Washington, D.C.), Defense Nuclear Facility Safety Board, Washington, D.C.

Conway, J. T., 1992, Defense Nuclear Facility Safety Board Recommendation 92-4, (letter to H. R. O'Leary, July 6, U.S. Department of Energy, Washington, D.C.), Defense Nuclear Facility Safety Board, Washington, D.C.

Conway, J. T., 1994, Defense Nuclear Facility Safety Board Recommendation 94-1, (letter to H. R. O'Leary, May 26, U.S. Department of Energy, Washington, D.C.), Defense Nuclear Facility Safety Board, Washington, D.C.

Conway, J. T., 1995, Defense Nuclear Facility Safety Board Recommendation 95-2, (letter to H. R. O'Leary, October 11, U.S. Department of Energy, Washington, D.C.), Defense Nuclear Facility Safety Board, Washington, D.C.

DOE Order 4700.1, Project Management System, U.S. Department of Energy, Washington, D.C.

DOE Order 5400.5, Radiation Protection of the Public and the Environment, Department of Energy, Washington, D.C.

DOE Order 5480.7A, Fire Protection, U. S. Department of Energy, Washington, D.C. 
DOE Order 5480.9A, Construction Project Safety and Health Management, U. S. Department of Energy, Washington, D.C.

DOE Order 5480.21, Unreviewed Safety Questions, U.S. Department of Energy, Washington, D.C.

DOE Order 5480.22, Technical Safety Requirements, U.S. Department of Energy, Washington, D.C.

DOE Order 5480.23, Nuclear Safety Analysis Reports, U.S. Department of Energy, Washington, D.C.

DOE Order 5480.24, Nuclear Criticality Safety, U.S. Department of Energy, Washington, D.C.

DOE Order 5480.31, Startup and Restart of Nuclear Facilities, U.S. Department of Energy, Washington, D.C.

DOE Order 5484.1, Environmental Protection, Safety, and Health Protection Information Reporting Requirements, U.S. Department of Energy, Washington, D.C.

DOE Order 6430.1A, General Design Criteria, U.S. Department of Energy, Washington, D.C.

DOE-STD-1027-92, Hazards Categorization and Accident Analysis Techniques for Compliance with DOE Order 5480.23, Nuclear Safety Analysis Reports, U.S. Department of Energy, Washington, D.C.

DOE-STD-3009-94, Preparation Guide for U.S. Department of Energy Nonreactor Nuclear Facility Safety Analysis Reports, U.S. Department of Energy, Washington, D.C.

DOE, 1994, RLID 5480.31, Startup and Restart of Facilities Operational Readiness Reviews and Readiness Assessments, U.S. Department of Energy, Richland Operations Office, Richland, Washington.

DOE, 1995, K Basins Spent Nuclear Fuel Project - Regulatory Policy, U.S. Department of Energy, Washington, D.C., Draft, May 1995.

DOE, 1996a, Department of Energy Plan for the Development and Implementation of Integrated Safety Management (Implementation Plan for Board Recommendation 95-2),

U.S. Department of Energy, Washington, D.C.

DOE, 1996b, Hanford Site Systems Engineering Policy, RLPD 430.1, U.S. Department of Energy, Richland, Operations Office, Richland, Washington. 
DOE, 1996c, Systems Engineering Criteria Document and Implementing Directive, RLID 430.1, U.S. Department of Energy, Richland, Operations Office, Richland, Washington.

DOE, 1996d, Management of Spent Nuclear Fuel from the $K$ Basins at the Hanford Site, Richland, Washington, DOE/EIS-0245F, U.S. Department of Energy, Washington, D.C.

DOE, 1996e, Record of Decision (ROD) for the Final Environmental Impact Statement (FEIS) on the Management of Spent Nuclear Fuel (SNF) from the K Basins at the Hanford Site, Richland, Washington, DOE/EIS-0245, U.S. Department of Energy, Washington, D.C.

Fulton, 1995, U. S. Department of Energy Actions and Approvals Required for Path Forward Schedule Acceleration, WHC Letter No. 9550592, (letter to C. A. Hansen, January 31 , U.S. Department of Energy, Richland Operations Office), Westinghouse Hanford Company, Richland, Washington.

Fulton, 1996a, Request for Approval of Second Revision of Memorandum of Understanding, WHC Letter No. 9652070, (letter to C. A. Hansen, May 6, U.S. Department of Energy, Richland Operations Office), Westinghouse Hanford Company, Richland, Washington.

Fulton, 1996b, Status of Urgent Actions on Spent Nuclear Fuel Project Issues, WHC Letter No. 9601402 B R2, (letter to C. A. Hansen, June 14, U.S. Department of Energy, Richland Operations Office), Westinghouse Hanford Company, Richland, Washington.

Grumbly, T. P., 1994, Delegation of Review and Approval Authority for Safety Documentation and for Startup/Restart for Environmental Management Field Offices, (memorandum to EM Deputy Assistant Secretaries Organizations and Field Office Managers, August 8), U.S. Department of Energy, Washington, D.C.

Lytle, J. E., 1995, Approval of K-Basins Spent Nuclear Fuel Project Action Plan, (memorandum to Thomas P. Grumbly, March 6), U.S. Department of Energy, Washington, D.C.

National Environmental Policy Act of 1970, 42 USC 4321 et seq.

NRC Regulatory Guide 3.26, Standard Format and Content of Safety Analysis Reports for Fuel Reprocessing Plants, U.S. Nuclear Regulatory Commission, Washington, D.C.

NRC Regulatory Guide 3.48, Standard Format and Content for the Safety Analysis Report for an Independent Spent Fuel Storage Installation (Dry Storage), Revision 1, U.S. Nuclear Regulatory Commission, Washington, D.C.

NRC Regulatory Guide 3.60, Design of an Independent Spent Fuel Storage Installation (Dry Storage), U.S. Nuclear Regulatory Commission, Washington, D.C. 
NRC Regulatory Guide 3.61, Standard Format and Content for a Topical Safety Analysis Report for a Spent Fuel Dry Storage Cask, U.S. Nuclear Regulatory Commission, Washington, D.C.

Resource Conservation and Recovery Act of 1976, 42 USC 6901 et seq.

Valdez, A., 1995, Cancellation of RLID 5480.23, "Safety Requirements for the Packaging and Transportation of Hazardous Materials, Hazardous Substances, and Hazardous Waste" and RLID-5480.1, Change 1, Chapter III, "Safety Requirements for the Packaging of Fissile and Other Radioactive Materials, " DOE Letter No. 95-SWT-186 (letter to Dr. A. L. Trego, March 29, Westinghouse Hanford Company), U.S. Department of Energy, Richland Operations Office, Richland, Washington.

WAC 173-216, State Waste Discharge Permit Program, Washington Administrative Code, Olympia, Washington.

WAC 173-303, Dangerous Waste Regulations, Washington Administrative Code, Olympia, Washington.

WAC 173-401, Effluent Guidelines and Standards: General Provisions, Washington Administrative Code, Olympia, Washington.

WAC 173-460, Controls for New Sources of Toxic Air Pollutants, Washington Administrative Code, Olympia, Washington.

WAC 197-11, SEPA Rules, Washington Administrative Code, Olympia, Washington.

WAC 246-247, Radiation Protection - Air Emissions, Washington Administrative Code, Olympia, Washington.

WAC 246-272, On-site Sewage System, Washington Administrative Code, Olympia, Washington.

Wagoner, J. D., 1994a, Site and Facility Standards/Requirements Identification Documents ( $S / R I D s)$, (memorandum to T. P Grumbly, February 10, U.S. Department of Energy, Washington, D.C.), U.S. Department of Energy, Richland Operations Office, Richland, Washington.

Wagoner, J. D., 1994b, Implementation of Defense Nuclear Facilities Safety Board (DNFSB) Recommendation 90-2, 9402018B, (letter to Dr. A. L. Trego, March 8, Westinghouse Hanford Company), U.S. Department of Energy, Richland Operations Office, Richland, Washington. 
Wagoner, J. D., 1995, RL Approval of the K Basin Standards/Requirements Identification Document, (letter to Dr. A. L. Trego, 95-SFD-203, November 27, Westinghouse Hanford Company), U.S. Department of Energy, Richland Operations Office, Richland, Washington.

WHC, 1994a, Hanford Spent Nuclear Fuel Project Recommended Path Forward, WHC-EP-0830, Rev. 0, Volumes I and II, Westinghouse Hanford Company, Richland, Washington.

WHC, 1994b, Report on Equivalent Safety for Transportation and Packaging of Radioactive Materials, WHC-SD-TP-RPT-001, Westinghouse Hanford Company, Richland, Washington.

WHC, 1994c, Document Control and Records Management Manual, WHC-CM-3-5, "Approval of Environmental, Safety, and Quality Affecting Documents," Chapter 12.7, Rev. 0, Westinghouse Hanford Company, Richland, Washington.

WHC, 1995a, Spent Nuclear Fuel Project Regulatory Strategy, WHC-SD-SNF-SP-002, Westinghouse Hanford Company, Richland, Washington.

WHC, 1995b, Hanford Spent Nuclear Fuel Project Integrated Process Strategy, WHC-SD-SNF-SP-005, Rev. 0, Westinghouse Hanford Company, Richland, Washington.

WHC, 1995c, Spent Nuclear Fuel Systems Engineering Management Plan, WHC-SD-SNFSEMP-001, Westinghouse Hanford Company, Richland, Washington.

WHC, 1995d, Spent Nuclear Fuel Project, Project Management Plan, WHC-SD-SNF-PMP-011, Revision 0 , Westinghouse Hanford Company, Richland, Washington.

WHC, 1995e, Spent Nuclear Fuel Project Path Forward, Nuclear Safety Equivalency to Comparable NRC-Licensed Facilities, WHC-SD-SNF-DB-002, Rev. 1, Westinghouse Hanford Company, Richland, Washington.

WHC, 1995f, Spent Nuclear Fuel Project Path Forward, Additional NRC Requirements, WHC-SD-SNF-DB-003, Rev. 1, Westinghouse Hanford Company, Richland, Washington.

WHC, 1995g, Multi-Canister Overpack, Additional NRC Requirements, WHC-SD-SNF-DB-005, Rev. 1, Westinghouse Hanford Company, Richland, Washington.

WHC, 1995h, Spent Nuclear Fuel Project Seismic Design Criteria, Nuclear Regulatory Commission Equivalency Evaluation Report, WHC-SD-SNF-DB-004, Westinghouse Hanford Company, Richland, Washington. 
WHC, 1995i, Spent Nuclear Fuel Project Tribal, Stakeholder, and Regulatory Communication and Participation Strategy, WHC-SD-SNF-SP-006, Westinghouse Hanford Company, Richland, Washington.

WHC, 1995j, SNF Project Configuration Management Plan, WHC-SD-SNF-CM-001, Westinghouse Hanford Company, Richland, Washington.

WHC, 1995k, $K$ Basins S/RIDs, WHC-SD-SNF-RD-001, Revision 0, Westinghouse Hanford Company, Richland, Washington.

WHC, 1995l, Spent Nuclear Fuel Project Interface Control Plan, WHC-SD-SNF-CM-003, Westinghouse Hanford Company.

WHC, 1995m, Standard Engineering Practices Manual, WHC-CM-6-1, Westinghouse Hanford Company, Richland, Washington.

WHC, 1995n, Establishment, Maintenance, and Control of S/RID Database, WHC Administrative Procedure 1-013-00, Westinghouse Hanford Company, Richland, Washington.

WHC, 1995o, Nuclear Criticality Safety Manual, WHC-CM-4-29, Westinghouse Hanford Company, Richland, Washington.

WHC, 1995p, Uniform Publication System, WHC-CM-3-6, Westinghouse Hanford Company, Richland, Washington.

WHC, 1995q, Hazardous Material Packaging and Shipping, WHC-CM-2-14, Westinghouse Hanford Company, Richland, Washington.

WHC, 1995r, Spent Nuclear Fuel Project Safety Analysis Report for Packaging (SARP) Approval Plan, WHC-SD-SNF-PLN-003, Rev. 0, Westinghouse Hanford Company, Richland, Washington.

WHC, 1995s, K Basin Sludge Packaging Design Criteria (PDC) and Safety Analysis Report for Packaging (SARP) Approval Plan, WHC-SD-SNF-PLN-015, Westinghouse Hanford Company, Richland, Washington.

WHC, 1995t, K Basins Self Assessments, WHC Administrative Procedure 1-010-01, Westinghouse Hanford Company, Richland, Washington.

WHC, 1995u, Spent Nuclear Fuel Project (SNFP) Technology Acquisition Plan, Rev. D, Draft, Westinghouse Hanford Company, Richland, Washington. 
WHC, 1995v, SNF Project Technical Databook, WHC-SD-SNF-TI-015, Westinghouse Hanford Company, Richland, Washington.

WHC, 1995w, Plan for Characterization of K Basins Spent Nuclear Fuel and Sludge, WHC-SD-SNF-PLN-007, Rev. 1, Westinghouse Hanford Company, Richland, Washington.

WHC, 1996a, Spent Nuclear Fuel Project Technical Baseline Document, Fiscal Year 1996, WHC-SD-SNF-SD-005, Westinghouse Hanford Company, Richland, Washington.

WHC, 1996b, SNF Project Quality Assurance Program Plan, WHC-SD-SNF-QAPP-004, Draft, Westinghouse Hanford Company, Richland, Washington.

WHC, 1996c, Safety Analysis Irradiated N Reactor Fuel, WHC-SD-WM-SAR-062, Rev. 2, Westinghouse Hanford Company, Richland, Washington.

WHC, 1996d, Operational Safety Requirements - 100-KE and 100-KW Fuel Storage Basins, WHC-SD-WM-OSR-006, Rev. 1, Westinghouse Hanford Company, Richland, Washington.

WHC, 1996e, Safety Analysis Manual, WHC-CM-4-46, Westinghouse Hanford Company, Richland, Washington.

WHC, 1996f, Standard Operating Procedures, WHC-CM-1-5, Westinghouse Hanford Company, Richland, Washington.

WHC, 1996g, Systematic End Point Criteria Development by Success Tree Analysis, Draft, Westinghouse Hanford Company, Richland, Washington.

WHC, 1996h, SNF Project Integrated Test Strategy, WHC-SD-SNF-CM-004, Westinghouse Hanford Company, Richland, Washington. 
WHC-SD-SNF-PLN-012

Rev. 2

This page intentionally left blank. 


\section{APPENDIX A \\ SPENT NUCLEAR FUEL PROJECT SAFETY ANALYSIS PLANNING PROCESS}

The safety analysis planning process integrates the preparation of accident analysis with the needs of the SNF Project design, construction, and readiness review activities. Preparation of the accident analysis is dependent on the information available from the project, including design detail, fuel characterization, sludge characterization, and operational cycles. The analysis is also dependent on the development of analytical models and testing results. The safety analysis planning objectives are as follows:

- Define safety analysis tools and SAR preparation activities.

- Schedule safety analysis activities in the context of subproject design, construction, and ORR events.

- Identify analysis information needs and need dates.

- Analysis validation needs and need dates.

- Identify and optimize resource utilization.

A general model of the logical relationships for preparation of the SAR Chapter 3 accident analysis is shown on Figure A-1 (all figures are included at the end of the appendix). An expansion of this logic is shown on Figure A-2. The figure demonstrates how, in some instances, the analysis must use the initial data available, then confirm the initial basis as better data is obtained. The planning process is most effective when it can be used to assure that data will be available when it is needed. The planning must also include contingencies for inadequate and/or untimely data supply. The contingency planning should include risk analyses and fall back positions, and/or show that the initial enabling assumptions are adequately conservative.

An overview of the safety analysis planning process is shown of Figure A-3. The preparation of the accident analysis planning sheet and the detailed schedules includes identification of required resources to perform the work and resource-loading of the schedules.

The logic for use of analytical tools and models for the analysis of MCO pressurization is shown as an example in Figure A-4. The data needs from other project sources and evolution of that data is depicted. Similar logics have been prepared for other analyses. Figure A-5 shows the logic of the analysis process for the CSB MCO Rupture Disk Release. The requirements for models, input data, and the analysis tasks are shown as logical blocks. The ties to the need date 
for SAR Chapter 3 submittal, the evolution of the initial basis, and the preparation of the final SAR are also shown.

The information from Figure A-5 is also shown in a matrix format in Figure A-6 (SAR Chapter 3 Accident Analysis Planning Sheet). An Accident Analysis Planning Sheet has been completed for each of the potential accidents to be analyzed for the CSB and CVD SARs. Planning sheets have not been prepared for the HCS SAR.

Figure A-7 is a selected portion of the Level 3 Safety/Permitting Planning Basis Integrated Schedule. This schedule is the vehicle for coordinating all safety and permitting activities within the overall project. The selected portion shows the dates and logical relationships for the accident analysis for the CSB and the CVD facilities with their primary analysis tool, the MCO Pressurization Study. The relationship of data from the design detail and characterization is incumbent, but the activities are not shown on this selection.

The logical relationships in the Level 3 schedule for the CSB MCO Rupture Disk accident analysis are shown on Figure A-8. This figure is produced from the scheduling software in the pure logic format. 
WHC-SD-SNF-PLN-012

Rev. 2

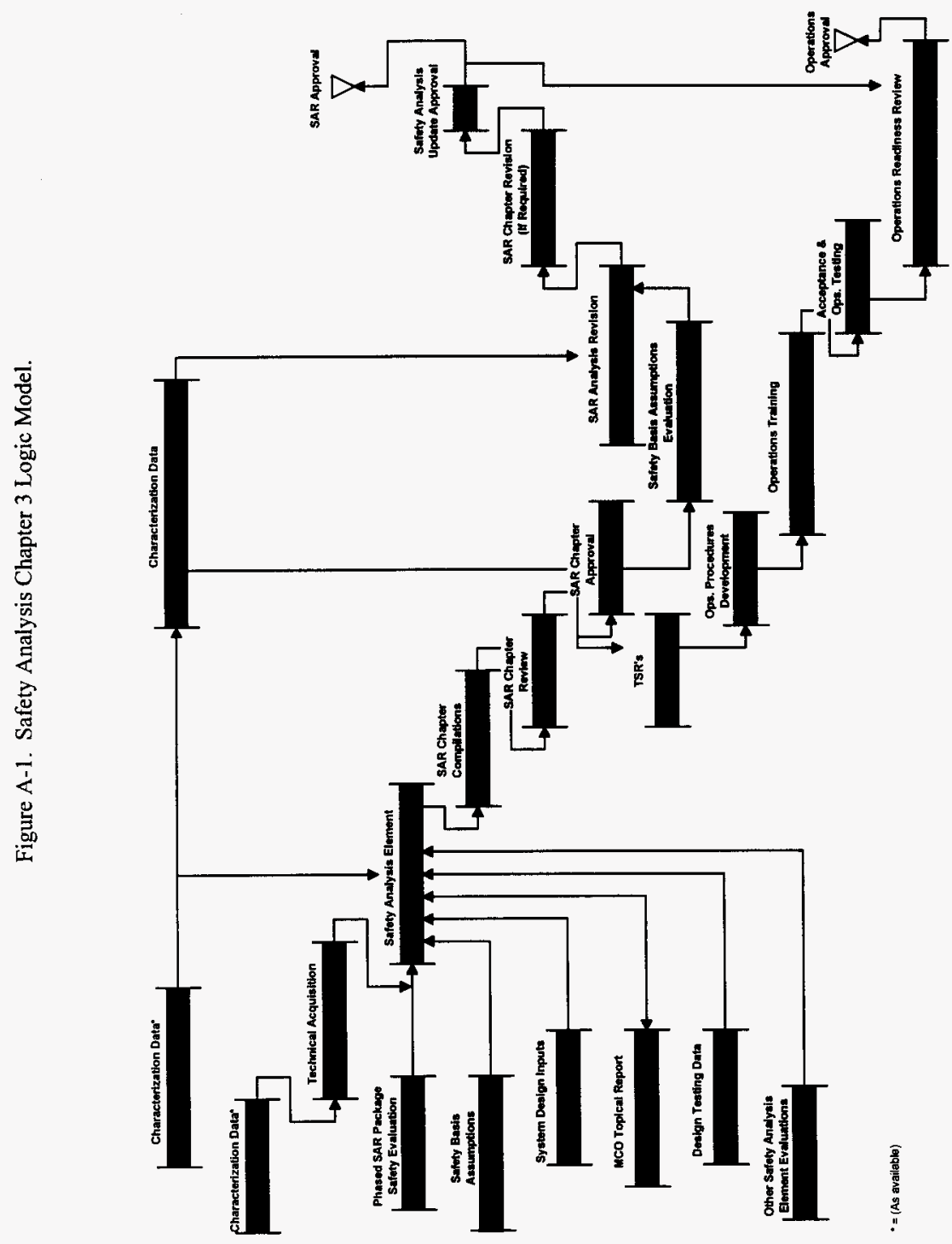


Figure A-2. Accident Analysis Overview and Assumptions Confirmation.

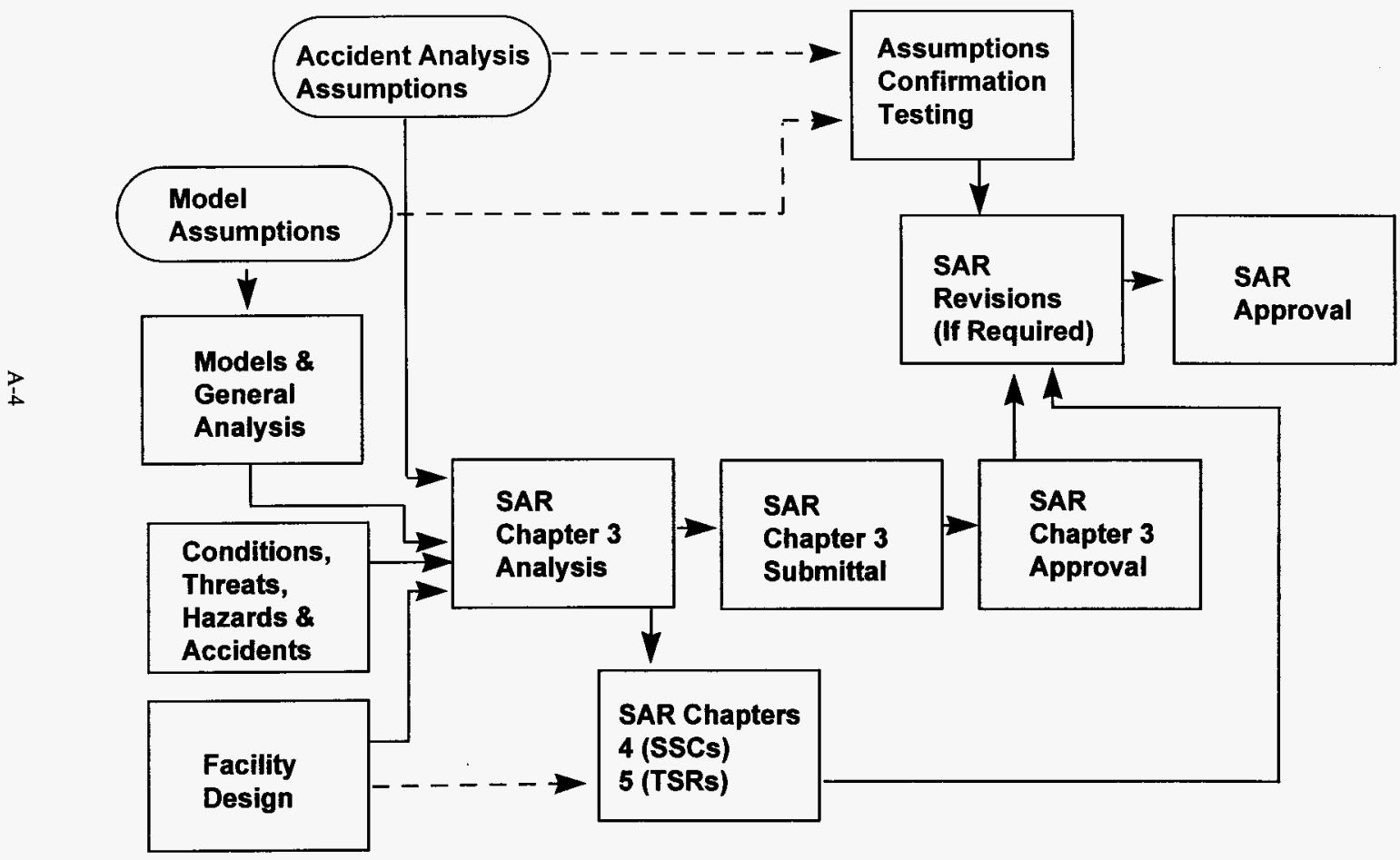


Figure A-3. SAR Accident Analysis Planning Path.

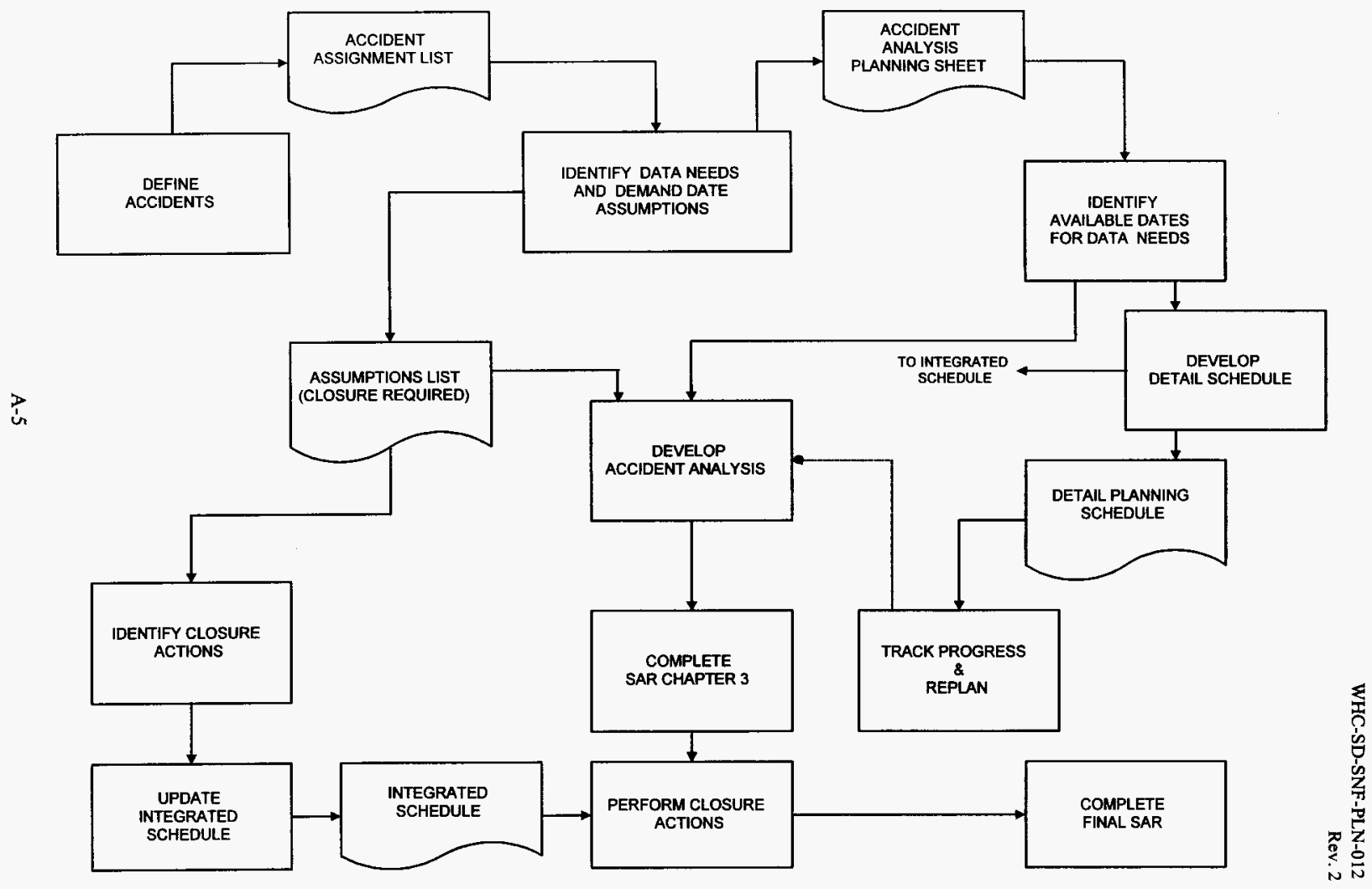


Figure A-4. Safety Evaluation Task \#4 MCO Pressurization Study (2 Sheets).

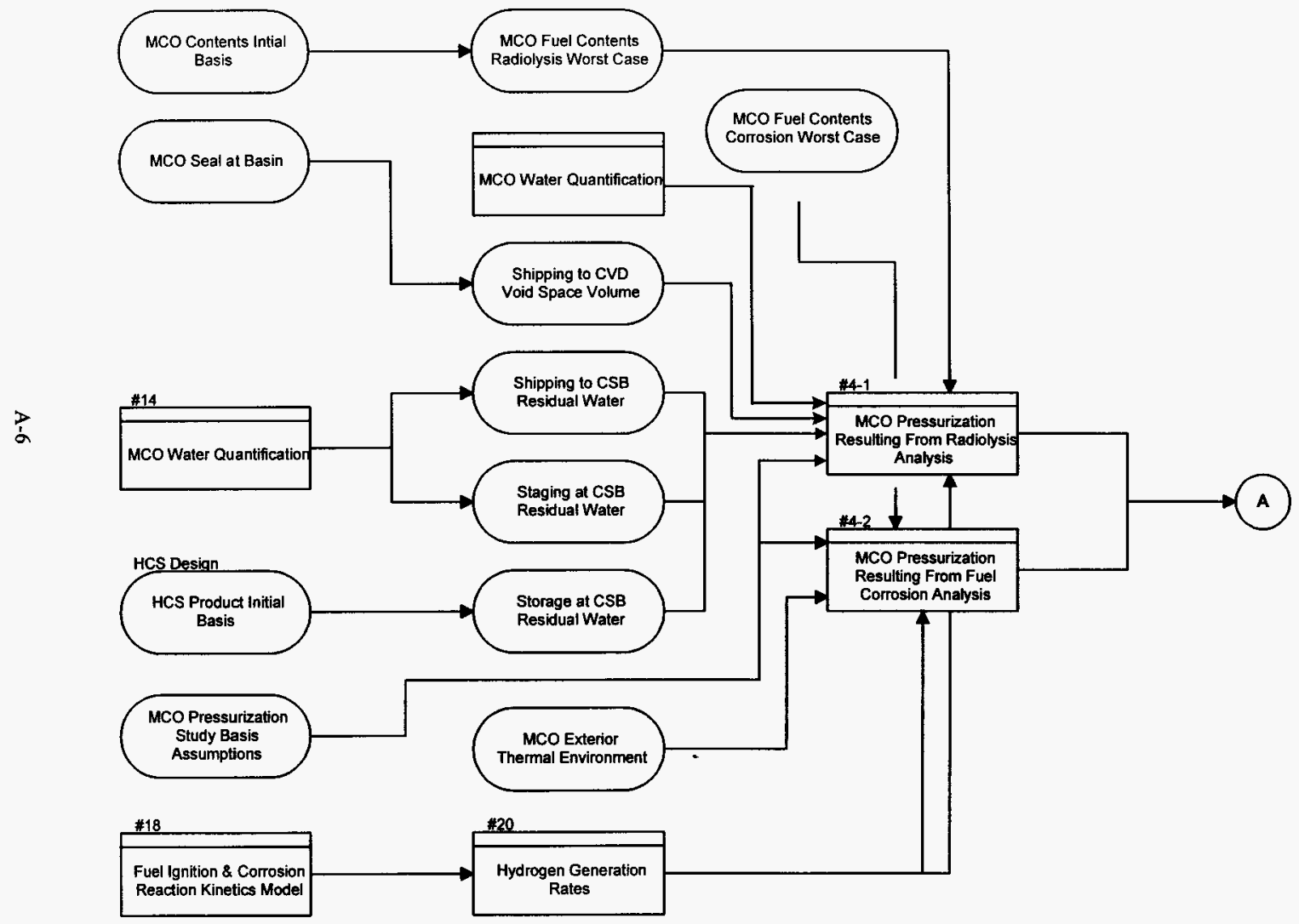


Figure A-4. Safety Evaluation Task \#4 MCO Pressurization Study (2 Sheets).

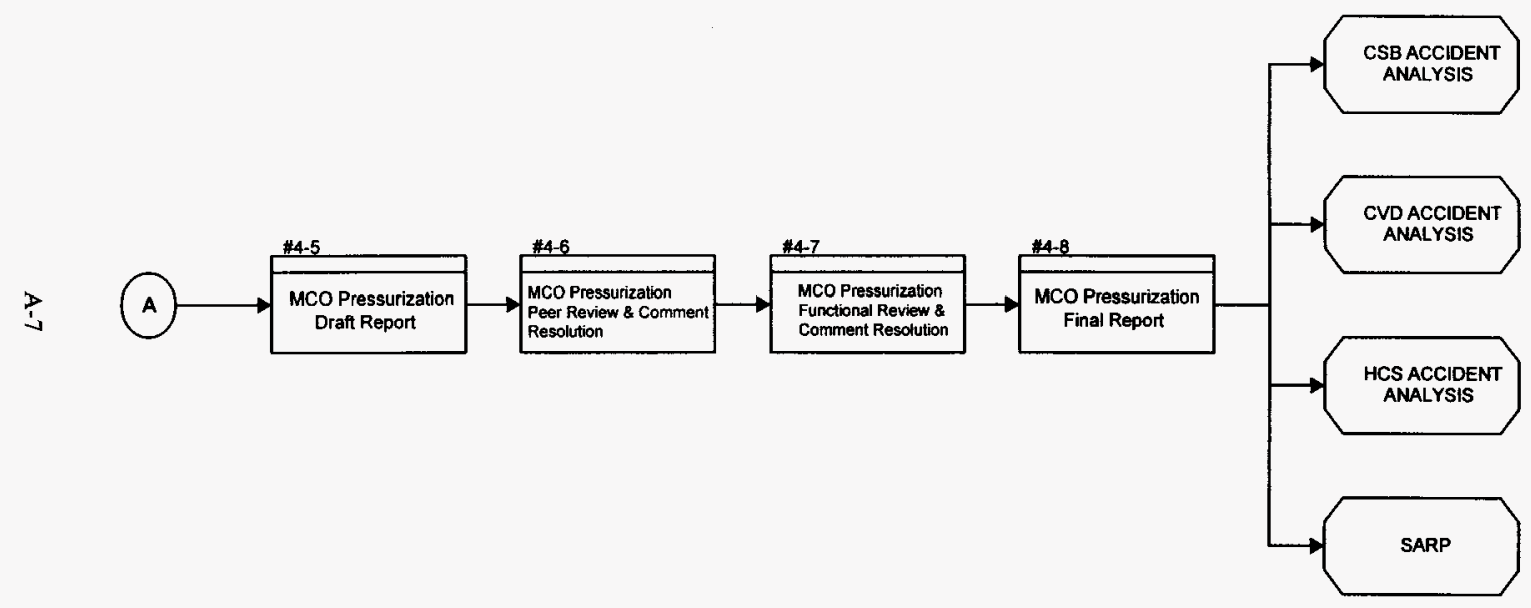




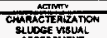

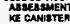

ALUDCE OUNNTTY

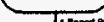

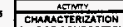

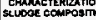

KE FLOOR

SLLDEE COUPONEMTS

Figure A-5. Safety Analysis Basis and Analysis

CSB MCO Rupture Disk Accident (3 Sheets).
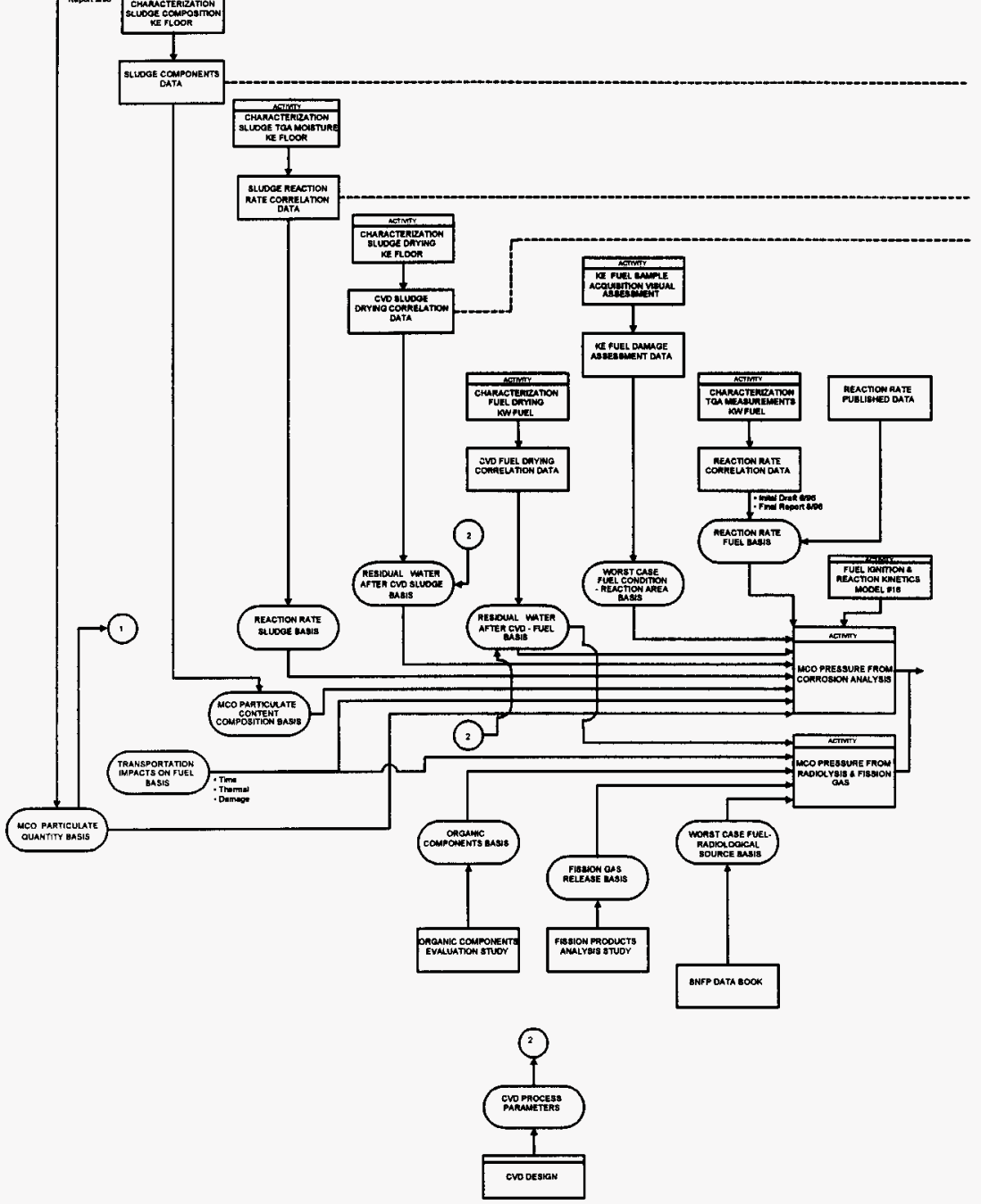
WHC-SD-SNF-PLN-012

Rev, 2

Figure A-5. Safety Analysis Basis and Analysis CSB MCO Rupture Disk Accident (3 Sheets).

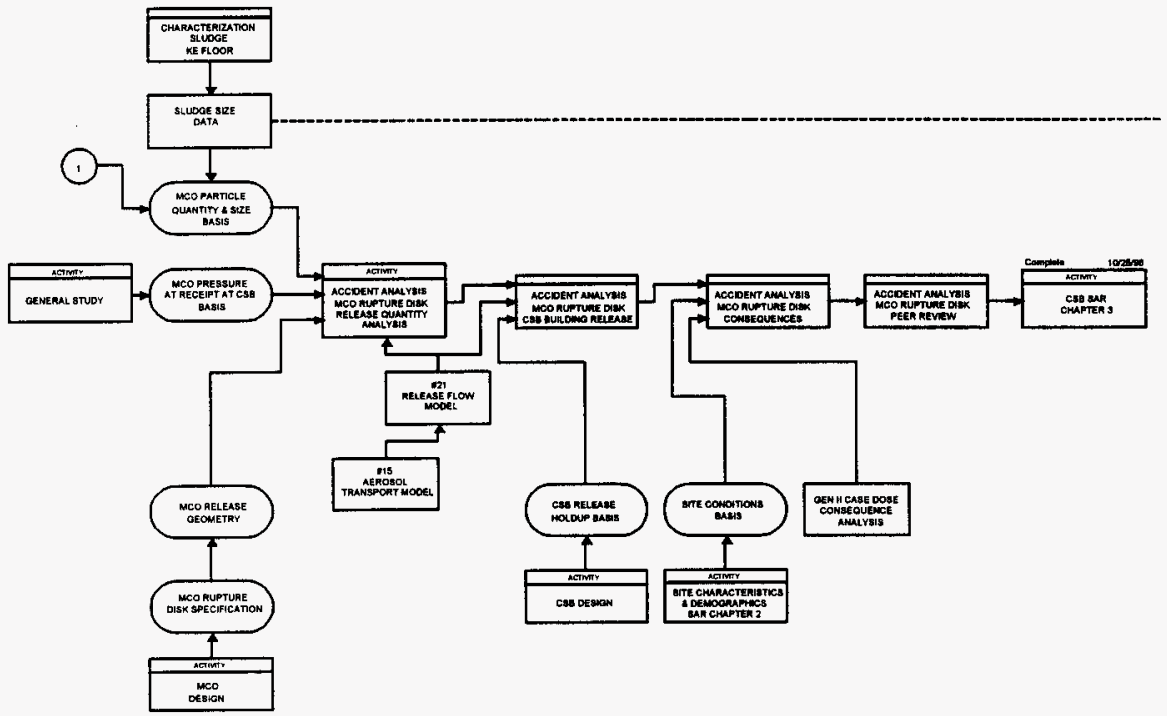


Figure A-5. Safety Analysis Basis and Analysis CSB MCO Rupture Disk Accident (3 Sheets).

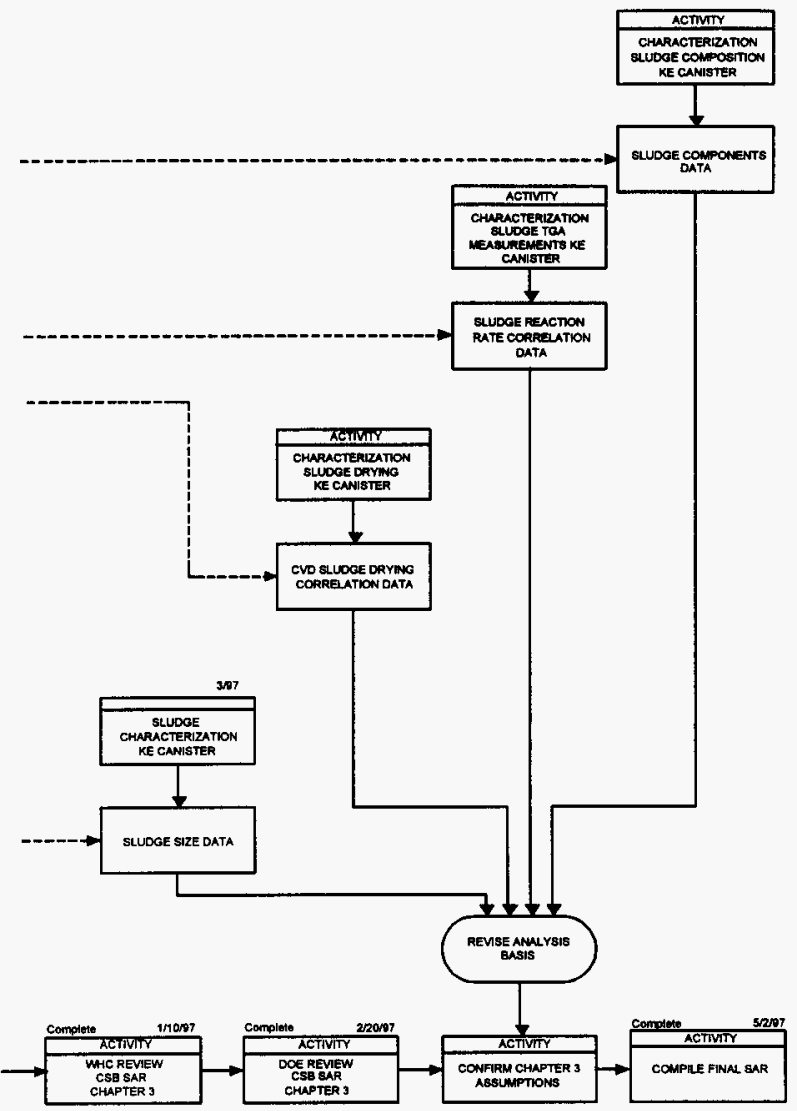


Figure A-6. SAR Chapter 3 Accident Analysis Planning Sheet (2 Sheets).

Facility:

Responsible Analyst:

Completion Demand Date:

Analysis Description:

\section{CANISTER STORAGE BUILDING}

L. Wojdac

MCO Pressurization, Rupture Disk Relief

MCO pressurized beyond the design limit of the rupture disk. This may happen in the CSB when the MCO is sealed (receiving or storage), or in the vented condition if the filter becomes plugged (staging). The specific scenario will depend on which events are deemed credible, based on final design, and which of the credible events is bounding from the standpoint of inventory released from the facility.

\begin{tabular}{|c|c|c|c|}
\hline Accident Analysis Input & Data Requirement & Responsibility & Date \\
\hline \multicolumn{4}{|l|}{ Design Information } \\
\hline $\begin{array}{l}\text { MCO rupture disk size }(\# 13) \\
\text { Pressure Limit } \\
\text { Flow Area }\end{array}$ & MCO Design Information & $\begin{array}{l}\text { MCO Topical Report } \\
\text { Lorenz }\end{array}$ & \\
\hline CSB Facility Configuration & CSB Design Information & Fluor & \\
\hline \multicolumn{4}{|l|}{ Design Assumptions } \\
\hline & $\therefore$ & & \\
\hline \multicolumn{4}{|l|}{ Radionuclide Inventory } \\
\hline MCO Contents - Worst Case & $\begin{array}{l}\text { Assessment of worst case fuel } \\
\text { loading. }\end{array}$ & Technical Databook & Complete \\
\hline Particulate (Oxide) Quantity (\#15) & $\begin{array}{l}\text { Justification for maximum oxide } \\
\text { quantity in MCO. }\end{array}$ & Cowan & \\
\hline \multicolumn{4}{|l|}{ Accident Conditions } \\
\hline Facility internal conditions & Process Information & & \\
\hline \multicolumn{4}{|l|}{ Models \& General Analysis } \\
\hline MCO pressurization (\#4) & $\begin{array}{l}\text { Conditions under which the MCO } \\
\text { can pressurize beyond its design } \\
\text { limit. }\end{array}$ & Duncan & \\
\hline Water Content & $\begin{array}{l}\text { Maximum verifiable water } \\
\text { content in the MCO after CVD, } \\
\text { and after HCS. }\end{array}$ & Wiborg & \\
\hline
\end{tabular}


Figure A-6. SAR Chapter 3 Accident Analysis Planning Sheet (2 Sheets).

\begin{tabular}{|c|c|c|c|}
\hline Accident Analysis Input & Data Requirement & Responsibility & Date \\
\hline $\mathrm{H}_{2}$ Generation Rates $(\# 20$ ) & $\begin{array}{l}\text { Maximum hydrogen generation } \\
\text { from radiolysis and fuel corrosion } \\
\text { during shipping from CVD and } \\
\text { during storage. }\end{array}$ & $\begin{array}{l}\text { Cooper/Wojdac - } \\
\text { Corrosion } \\
\text { Kummerer - Radiolysis }\end{array}$ & \\
\hline $\begin{array}{l}\text { Fuel Reaction Kinetics } \\
(\# 18)\end{array}$ & $\begin{array}{l}\text { Hydrogen generation rates from } \\
\text { corrosion reaction under accident } \\
\text { conditions. }\end{array}$ & Cooper/Wojdac & \\
\hline Reiease Model (\#21) & $\begin{array}{l}\text { Airborne mass transport rates out } \\
\text { of the MCO and facility under } \\
\text { accident conditions. }\end{array}$ & Lee/Kummerer & \\
\hline $\begin{array}{l}\text { Aerosol Transport Model } \\
(\# 17)\end{array}$ & $\begin{array}{l}\text { Release reduction by particulate } \\
\text { retention in the MCO and facility } \\
\text { due to aerosol agglomeration, } \\
\text { plateout and settling. }\end{array}$ & Lee/Kummerer & \\
\hline $\begin{array}{l}\text { Dry Oxide Particle Size } \\
\text { Distribution (\#16) }\end{array}$ & $\begin{array}{l}\text { Particle size distribution of oxide } \\
\text { particles for input to aerosol } \\
\text { transport model. }\end{array}$ & Omberg & \\
\hline \multicolumn{4}{|l|}{ Accident Assumptions } \\
\hline $\begin{array}{l}\text { Oxide particulates same } \\
\text { radionuclide content as worst case } \\
\text { fuel. }\end{array}$ & & & \\
\hline & & & \\
\hline
\end{tabular}


Figure A-7. Level 3 Safety/Permitting Planning Basis Integrated Schedule Bar Chart Format (2 Sheets).

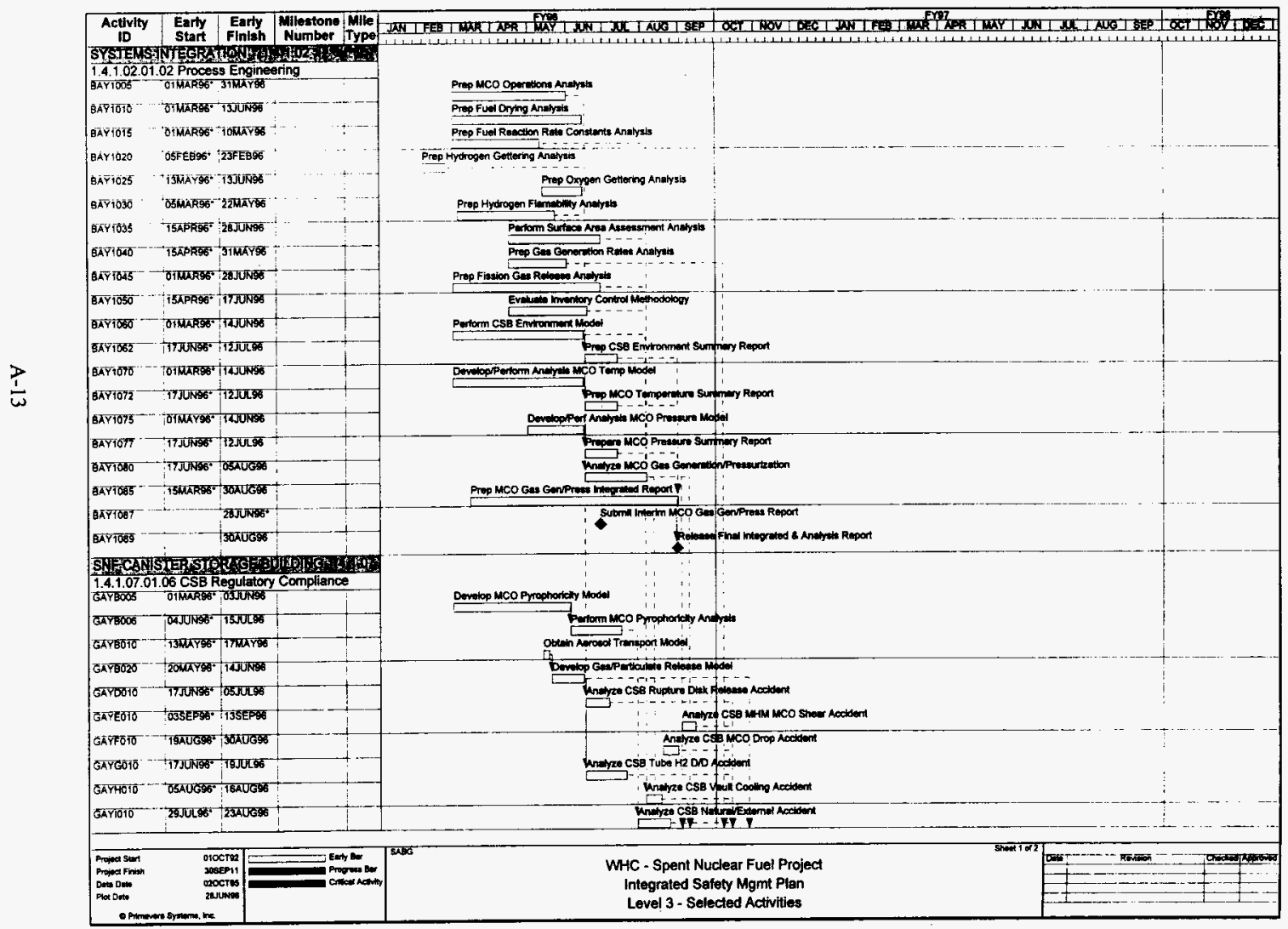




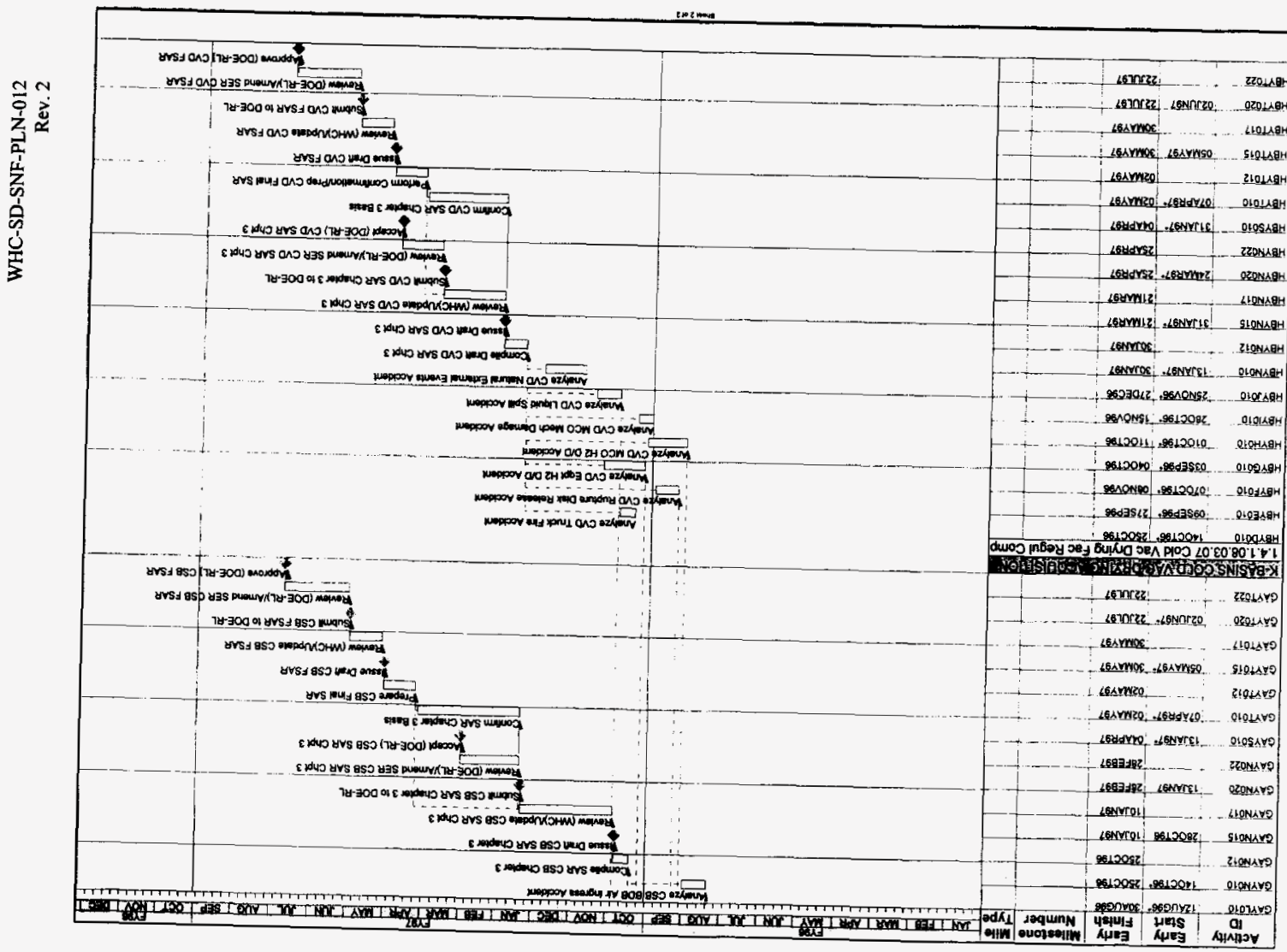

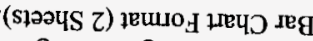

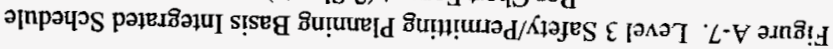


Figure A-8. Level 3 Safety/Permitting Basis Integrated Schedule

\section{Logic Block Format.*}

\subsection{Process Engineering}

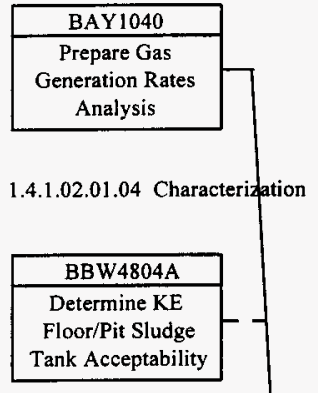

1.4.1.05.01.03 MCO Design

\begin{tabular}{|c|}
\hline FAWA251.1 \\
\hline $\begin{array}{c}\text { [PBF] Complete } \\
\text { MCO Phase I } \\
\text { Design }\end{array}$ \\
\hline
\end{tabular}

1.4.1.07.01.06 CSB Regulatory Compliance

\begin{tabular}{|c|c|c|c|c|}
\hline BAYB020 & & GAYD010 & & GAYN010 \\
\hline $\begin{array}{l}\text { Develop Gas/ } \\
\text { Particulate } \\
\text { Release Model }\end{array}$ & $--\frac{1}{1}$ & $\begin{array}{c}\text { Analyze CSB } \\
\text { Rupture Disk } \\
\text { Release Accident }\end{array}$ & $-\infty$ & $\begin{array}{c}\text { Compile CSB SAR } \\
\text { Chapter } 3\end{array}$ \\
\hline
\end{tabular}

1.4.1.07.01.03 CSB Design,

1

\begin{tabular}{|c|c|}
\hline GAW3304010 & 1 \\
\cline { 1 - 1 } $\begin{array}{c}\text { CSB Definitive } \\
\text { Design }\end{array}$ & 1 \\
FS-50 \\
\hline
\end{tabular}

*This diagram was extracted from a Project Schedule, Primavera Logic Block Format. 
WHC-SD-SNF-PLN-012

Rev. 2

This page intentionally left blank. 


\section{APPENDIX B}

\section{SUMMARY OF TECHNOLOGY ACQUISITION PROGRAM AND CHARACTERIZATION PROGRAM TECHNICAL REPORTS}

Table B-1 provides a summary of the process design models and analyses and summarizes the verification, validation, and testing required to support completion of the SNF Project. Table B-2 provides a similar summary of safety analyses (i.e., SAR Chapter 3 analyses) and modeling needs for the new facilities being constructed by the SNF Project, along with an identification of data needs and model validation plans. This Appendix also provides a listing of the TAP (Table B-3), Characterization Program (Table B-4), and Process Engineering (Table B-5) technical reports that have been completed or that are required to support the SNF Project. The listings includes report numbers, titles, a summary of the report scope/content, and a correlation with the required safety design and safety analysis models that are supported by the technical reports in Tables B-1 and B-2.

The reports listed in these tables represent the necessary and sufficient set of documents currently planned to support the SNF Project safety analysis. They are provided here to illustrate the integration process between characterization/TAP/Process Engineering and the safety analysis process. Report schedules and scopes can be expected to change as new information is developed. 
Table B-1. Spent Nuclear Fuel Process Model Verification Matrix (12 Sheets).

Multi-Canister Overpack - Spent Nuclear Fuel Model Verification Matrix

\begin{tabular}{|c|c|c|c|c|c|c|}
\hline \multirow{2}{*}{$\begin{array}{c}\text { Issue/ } \\
\text { Verification } \\
\text { Model }\end{array}$} & \multicolumn{3}{|c|}{ Design Calculation Support } & \multicolumn{3}{|c|}{ Process Verification } \\
\hline & $\begin{array}{c}\text { Characterization } \\
\text { Tests }\end{array}$ & Date Available & $\begin{array}{c}\text { Date } \\
\text { Needed }\end{array}$ & Process Tests & $\begin{array}{l}\text { Date } \\
\text { Avail. }\end{array}$ & $\begin{array}{c}\text { Date } \\
\text { Needed }\end{array}$ \\
\hline \multirow[t]{2}{*}{$\begin{array}{l}\text { MCO Pressure, } \\
\text { Hydrogen and } \\
\text { Oxygen } \\
\text { Content/Gas } \\
\text { Generation } \\
\text { Report } \\
\end{array}$} & $\begin{array}{l}\text { Fuel } \\
\text { - Drying curves } \\
\text { - } \mathrm{H}_{2} \mathrm{O} \text { Content } \\
\text { - Ignition Potential } \\
\text { - Reaction Kinetics } \\
\text { - } \mathrm{H}_{2} \text { Generation } \\
\end{array}$ & $\begin{array}{l}\text { Fuel highlight reports have been produced on a continual } \\
\text { basis beginning September } 9,1995 \text { for KW fuel with the } \\
\text { first major deliverable due August 1996; similarly data } \\
\text { highlight reports are being produced on a continual basis } \\
\text { for KE fuel beginning May } 1996 \text { with the final report } \\
\text { due August } 1997 \text {. }\end{array}$ & $12 / 96$ & \multirow[t]{2}{*}{$\begin{array}{l}\text { Prototype MCO } \\
\text { Benchmark Tests } \\
\text { (CVD/HCS Pilot } \\
\text { Scale Testing) })^{1,2,3}\end{array}$} & \multirow[t]{2}{*}{$10 / 96$} & \multirow[t]{2}{*}{$12 / 96$} \\
\hline & $\begin{array}{l}\text { Sludge } \\
\text { - Drying Curves } \\
\text { - } \mathrm{H}_{2} \mathrm{O} \text { Content } \\
\text { - Chemical Content } \\
\text { - Particle Size } \\
\text { Distribution }\end{array}$ & $\begin{array}{l}\text { The first data highlight report on KE floor sludge was } \\
\text { issued in January 1996, and the first major report issued } \\
\text { in April 1996; similarly highlight reports are currently } \\
\text { being produced on KE canister sludge with the first } \\
\text { major report due March } 1997 \text {; highlight reports on KW } \\
\text { canister sludge will follow with a major report due in } \\
\text { May } 1997 \text {. }\end{array}$ & $12 / 96$ & & & \\
\hline
\end{tabular}

See attached MCO Test Program Overview.

${ }^{2}$ See CVD and HCS Test Program Overviews.

${ }^{3}$ All tests are budgeted.

\begin{tabular}{|l|l|l||}
\hline \multicolumn{1}{|c|}{ End Point Criteria } & \multicolumn{1}{|c|}{ Basis } & \multicolumn{1}{|c|}{ Interim Assumptions } \\
\hline $\begin{array}{l}\text { MCO } \\
\text { MCO pressure } \leq 150 \mathrm{psig}\end{array}$ & $150 \mathrm{psig}$ nominal design pressure. & $\begin{array}{l}\text { Molar quantities of constituents in MCO after conditioning } \\
\text { that will result in gases < that necessary to limit MCO } \\
\text { pressure to }<150 \mathrm{psig} .\end{array}$ \\
\hline
\end{tabular}


Table B-1. Spent Nuclear Fuel Process Model Verification Matrix (12 Sheets).

Multi-Canister Overpack Test Program Overview

\begin{tabular}{|c|c|c|c|c|c|}
\hline & Process Tests & Description & Test Plan & Start & Finish \\
\hline & $\begin{array}{l}\text { MCO Load } \\
\text { Test }\end{array}$ & $\begin{array}{l}\text { Inserting pre-loaded repack baskets into a mock-up MCO. Three } \\
\text { basket types were tested; Mark IA, Mark IV, and SPR. Tests } \\
\text { included off-center basket loading, basket stacking within the } \\
\text { MCO, and basket load tests at } 125 \% \text { capacity. }\end{array}$ & $\begin{array}{l}\text { Test Plan WHC-SD-SNF-TP-026 } \\
\text { was issued } 4 / 15 / 96 \text {. } \\
\text { Test Report WHC-SD-SNF-TRP-014 } \\
\text { was issued } 5 / 30 / 96 \text {. }\end{array}$ & $4 / 15 / 96$ & $5 / 30 / 96$ \\
\hline \multirow{3}{*}{ ه్ } & Welding Tests & $\begin{array}{l}\text { Development and qualification testing of weld process and } \\
\text { equipment. Includes functional testing on prototype hardware to } \\
\text { demonstrate achievability of weld. Qualification testing will } \\
\text { develop weld parameters per ASME code and lead to drafting of } \\
\text { Weld Procedure Specification. }\end{array}$ & $\begin{array}{l}\text { Draft Closure Weld Test Plan } \\
\text { WHC-SD-SNF-TP-015 out for } \\
\text { review. Scheduled for release } \\
6 / 15 / 96 .\end{array}$ & $7 / 18 / 96$ & $12 / 11 / 96$ \\
\hline & $\begin{array}{l}\text { Mechanical } \\
\text { Closure Tests }\end{array}$ & $\begin{array}{l}\text { Focus on testing quality and integrity of mechanical seal. Leak } \\
\text { rate testing of normally installed seal and off normal condition of } \\
\text { debris left on sealing surface. Includes seal testing after vibration } \\
\text { on a shaker table and after } 100 \mathrm{C} \text { thermal differential between } \\
\text { plug and shell. }\end{array}$ & $\begin{array}{l}\text { Test plan being drafted. Scheduled } \\
\text { for release by } 7 / 1 / 96\end{array}$ & $7 / 24 / 96$ & $8 / 29 / 96$ \\
\hline & $\begin{array}{l}\text { Functional } \\
\text { Tests }\end{array}$ & $\begin{array}{l}\text { Insertion of shield plug and dip tube into MCO, thru repack } \\
\text { baskets; air sparge test to remove water beneath shield plug } \\
\text { preparatory to welding, vessel pressure test, and rupture disc } \\
\text { testing. }\end{array}$ & $\begin{array}{l}\text { Test plan scheduled for release by } \\
8 / 15 / 96\end{array}$ & $8 / 30 / 96$ & $9 / 30 / 96$ \\
\hline
\end{tabular}


Table B-1. Spent Nuclear Fuel Process Model Verification Matrix (12 Sheets).

Cold Vacuum Drying System - Spent Nuclear Fuel Process Model Verification Matrix

\begin{tabular}{|c|c|c|c|c|c|c|}
\hline \multirow{2}{*}{$\begin{array}{l}\text { Issue/ } \\
\text { Verification } \\
\text { Model }\end{array}$} & \multicolumn{3}{|c|}{ Design Calculation Support } & \multicolumn{3}{|c|}{ Process Verification } \\
\hline & $\begin{array}{c}\text { Characterization } \\
\text { Tests }\end{array}$ & Date Available & $\begin{array}{c}\text { Date } \\
\text { Needed }\end{array}$ & Process Tests & $\begin{array}{l}\text { Date } \\
\text { Avail. }\end{array}$ & $\begin{array}{c}\text { Date } \\
\text { Needed }\end{array}$ \\
\hline \multirow[t]{3}{*}{$\begin{array}{l}\text { CVD System } \\
\text { Cycle Time/ } \\
\text { Witness } \\
\text { Model }\end{array}$} & $\begin{array}{l}\text { Fuel } \\
\text { - Drying curves } \\
\text { - } \mathrm{H}_{2} \mathrm{O} \text { Content } \\
\text { - Ignition Potential } \\
\text { - Reaction Kinetics } \\
\text { - } \mathrm{H}_{2} \text { Generation } \\
\end{array}$ & $\begin{array}{l}\text { Fuel highlight reports have been produced on a continual basis } \\
\text { beginning September } 9,1995 \text {, for KW fuel with the first major } \\
\text { deliverable due August 1996; similarly data highlight reports } \\
\text { are being produced on a continual basis for KE fuel beginning } \\
\text { May } 1996 \text { with the final report due August } 1997 \text {. }\end{array}$ & Now & $\begin{array}{l}\text { Proof of Concept } \\
\text { Test }^{1,2}\end{array}$ & $8 / 96$ & $10 / 96$ \\
\hline & & & & $\begin{array}{l}\text { Process Equipment } \\
\text { Testing Pump, RGA, } \\
\text { MCO internal filter }{ }^{1,2}\end{array}$ & $8 / 96$ & $10 / 96$ \\
\hline & $\begin{array}{l}\text { Sludge } \\
\text { - Drying Curves } \\
\text { - } \mathrm{H}_{2} \mathrm{O} \text { Content } \\
\text { - Chemical Content } \\
\text { - Particle Size } \\
\text { Distribution } \\
\end{array}$ & $\begin{array}{l}\text { The first data highlight report on KE floor sludge was issued in } \\
\text { January 1996, and the first major report issued in April 1996; } \\
\text { similarly highlight reports are currently being produced on KE } \\
\text { canister sludge with the first major report due March 1997; } \\
\text { highlight reports on KW canister sludge will follow with a } \\
\text { major report due in May } 1997 \text {. }\end{array}$ & Now & $\begin{array}{l}\text { Prototype MCO } \\
\text { Benchmark Tests } \\
\text { (CVD System Pilot } \\
\text { Scale Testing) }\end{array}$ & $10 / 96$ & $10 / 96$ \\
\hline \multirow[t]{2}{*}{$\begin{array}{l}\text { CVD System } \\
\text { Cycle Time! } \\
\text { Thermal } \\
\text { Hydraulic } \\
\text { Model }\end{array}$} & $\begin{array}{l}\text { Fuel } \\
\text { - Drying Curves } \\
\text { - } \mathrm{H}_{2} \mathrm{O} \text { Content } \\
\text { - } \mathrm{H}_{2} \text { Generation } \\
\text { - Reaction Kinetics } \\
\text { - Ignition Potential }\end{array}$ & $\begin{array}{l}\text { Fuel highlight reports have been produced on a continual basis } \\
\text { beginning September } 9,1995 \text {, for KW fuel with the first major } \\
\text { deliverable due August } 1996 \text {; similarly data highlight reports } \\
\text { are being produced on a continual basis for KE fuel beginning } \\
\text { May } 1996 \text { with the final report due August } 1997 \text {. }\end{array}$ & Now & $\begin{array}{l}\text { Prototype MCO } \\
\text { Benchmark Tests } \\
\text { (CVD System) Pilot } \\
\text { Scale Testing, }{ }^{1,2}\end{array}$ & $10 / 96$ & $10 / 96$ \\
\hline & $\begin{array}{l}\text { Sludge } \\
\text { - Drying curves } \\
\text { - } \mathrm{H}_{2} 0 \text { Content } \\
\text { - Chemical } \\
\text { Composition }\end{array}$ & $\begin{array}{l}\text { The first data highlight report on KE floor sludge was issued in } \\
\text { January 1996, and the first major report issued in April 1996; } \\
\text { similarly highlight reports are currently being produced on KE } \\
\text { canister sludge with the first major report due March 1997; } \\
\text { highlight reports on KW canister sludge will follow with a } \\
\text { major report due in May } 1997 \text {. }\end{array}$ & Now & & & \\
\hline
\end{tabular}

\footnotetext{
See attached CVD Pro
All tests are budgeted.
} 
Table B-1. Spent Nuclear Fuel Process Model Verification Matrix (12 Sheets).

Cold Vacuum Drying System - Spent Nuclear Fuel Process Model Verification Matrix (2 Sheets)

\begin{tabular}{|l|l|l|}
\hline \multicolumn{1}{|c|}{ End Point Criteria } & \multicolumn{1}{|c|}{ Basis } & \multicolumn{1}{|c|}{ Interim Assumptions } \\
\hline CVD & $\begin{array}{l}\text { End point ensures MCO will not } \\
\text { overpressurize during transportation window. }\end{array}$ & $\begin{array}{l}\text { CVD system will remove enough free water } \\
\text { to prevent overpressurization of MCO during } \\
\text { normal transportation conditions. } \\
\text { 2. Mold vacuum }<3 \text { torr for } 1 \text { hour. } \\
<\text { TBD. }\end{array}$ \\
3. MCO temperature cooled to $25^{\circ} \mathrm{C}$ & & \\
\hline
\end{tabular}

\begin{tabular}{||l|l|l||}
\hline \multicolumn{1}{|c|}{ End Point Criteria } & \multicolumn{1}{|c|}{ Measurement } & \multicolumn{1}{|c|}{ Measurement Basis } \\
\hline $\begin{array}{l}\text { CVD } \\
\text { 1. Hold vacuum }<3 \text { torr for } 1 \text { hour. } \\
\text { 2. Measured } \mathrm{H}_{2} \text { generation rate at } 75^{\circ} \mathrm{C} \\
<\text { TBD. }\end{array}$ & $\begin{array}{l}\text { MCO temperature } \leq 25^{\circ} \mathrm{C} . \\
\mathrm{H}_{2} \text { Generation Rate at } 75^{\circ} \mathrm{C}<\mathrm{TBD} .\end{array}$ & $\begin{array}{l}\text { MCO pressure will not }>150 \mathrm{psig} \text { during } \\
\text { transportation window if criteria are met. }\end{array}$ \\
$\begin{array}{l}\text { 3. MCO temperature cooled to } 25^{\circ} \mathrm{C} . \\
\end{array}$ & $\begin{array}{l}\text { Measure pressure after } \mathrm{CVD} \text { to ensure } \\
\text { vacuum maintained }<3 \text { torr for } 1 \text { hour. }\end{array}$ & $\begin{array}{l}\text { Standard Industrial Practice, provides } \\
\text { evidence that free water has been removed. }\end{array}$ \\
\hline
\end{tabular}


Table B-1. Spent Nuclear Fuel Process Model Verification Matrix (12 Sheets).

Cold Vacuum Drying System Project Test Program Overview

\begin{tabular}{|c|c|c|c|c|}
\hline Process Tests & Description & Test Plan & Start & Finish \\
\hline $\begin{array}{l}5.1 \\
\text { Proof of Concept Test } \\
\text { (Water Retention, } \\
\text { baseline testing, mock } \\
\text { fuel drying) }\end{array}$ & $\begin{array}{l}\text { This series of tests examines the amount and location of water } \\
\text { retained in a single-tier MCO basket full of mock fuel and } \\
\text { sludge. These tests shall be performed at the } 305 \text { building. } \\
\text { Equipment required for MCO water retention site is: one full- } \\
\text { scale MCO fuel basket, mock N Reactor fuel (good and very } \\
\text { poor condition), mock fuel bits, mock sludge, and green fuel. }\end{array}$ & $\begin{array}{l}\text { Test Plan in draft } \\
\text { (WHC-SD-SNF-TP-018) } \\
\text { Target release date } 7 / 1 / 96\end{array}$ & $6 / 17 / 96$ & $8 / 2 / 96$ \\
\hline $\begin{array}{l}5.2 \\
\text { Process Equipment } \\
\text { Testing }\end{array}$ & $\begin{array}{l}\text { These tests shall utilize the modified glove box/vacuum } \\
\text { chamber located in the } 306 \mathrm{E} \text { Facility. This section shall } \\
\text { examine the pump performance over a prolonged run, and } \\
\text { Residual Gas Analyzer (RGA) responses to air in-leakage. In } \\
\text { addition, residual water detection, bulk water removal and } \\
\text { totalization, dewpoint residual water detection; and prototype } \\
\text { MCO internal HEPA filter will be tested. Will also test } \\
\text { instrumentation, data collection, and control system operation. } \\
\text { Additional equipment required for the equipment performance } \\
\text { tests are: } \\
\text { - Mock N-Reactor fuel } \\
\text { - Mock sludge } \\
\text { - Scroll pump } \\
\text { - Prototype off-gas monitoring system } \\
\text { - Prototype MCO internal HEPA filter, and } \\
\text { - Bottled xenon or krypton and hydrogen sources. }\end{array}$ & $\begin{array}{l}\text { Test Plan in draft } \\
\text { (WHC-SD-SNF-TP-018) } \\
\text { Target release date } 7 / 1 / 96\end{array}$ & $6 / 17 / 96$ & $8 / 2 / 96$ \\
\hline $\begin{array}{l}5.3 \\
\text { Prototype } \\
\text { Performance Testing } \\
\text { (Full-Scale Design } \\
\text { Testing) }\end{array}$ & $\begin{array}{l}\text { The proof of performance testing allows final laboratory testing } \\
\text { for design adjustments to the prototypes before final } \\
\text { installation. The proof of performance tests shall include full- } \\
\text { scale MCO drying tests, prototype vacuum module tests, and } \\
\text { finally complete prototypic CVD system tests. }\end{array}$ & $\begin{array}{l}\text { Test Plan in draft } \\
\text { (WHC-SD-SNF-TP-018) } \\
\text { Target release date } 7 / 1 / 96\end{array}$ & $8 / 30 / 96$ & $12 / 31 / 96^{1}$ \\
\hline
\end{tabular}

${ }^{1}$ Data available October 1996. 
Table B-1. Spent Nuclear Fuel Process Model Verification Matrix (12 Sheets).

Hot Vacuum Conditioning System - Spent Nuclear Fuel Process Model Verification Matrix (2 Sheets)

\begin{tabular}{|c|c|c|c|c|c|c|}
\hline \multirow{2}{*}{$\begin{array}{c}\text { Issue/ } \\
\text { Verification } \\
\text { Model }\end{array}$} & \multicolumn{3}{|c|}{ Design Calculation Support } & \multicolumn{3}{|c|}{ Process Verification } \\
\hline & $\begin{array}{c}\text { Characterization } \\
\text { Tests }\end{array}$ & Date Available & $\begin{array}{c}\text { Date } \\
\text { Needed }\end{array}$ & Process Tests & $\begin{array}{c}\text { Date } \\
\text { Avail. }\end{array}$ & $\begin{array}{l}\text { Date } \\
\text { Needed }\end{array}$ \\
\hline $\begin{array}{l}\text { HCS } \\
\mathrm{H}_{2} \text { Flammability/ } \\
\mathrm{H}_{2} \text { Release } \\
\text { Calculation }\end{array}$ & $\begin{array}{l}\mathrm{H}_{2} \text { Generation } \\
\mathrm{K} \text { West } \\
\mathrm{H}_{2} \text { Generation } \\
\mathrm{K} \text { East }\end{array}$ & $\begin{array}{l}\text { Fuel highlight reports have been produced } \\
\text { on a continual basis beginning September } 9 \text {, } \\
1995 \text {, for KW fuel with the first major } \\
\text { deliverable due August 1996; similarly data } \\
\text { highlight reports are being produced on a } \\
\text { continual basis for KE fuel beginning May } \\
1996 \text { with the final report due August } 1997 \text {. }\end{array}$ & $12 / 96$ & $\begin{array}{l}\text { Process Equipment } \\
\text { Testing and System } \\
\text { Response } \\
\text { Testing }{ }^{1,3}\end{array}$ & $12 / 96^{2}$ & $12 / 96^{2}$ \\
\hline \multirow[t]{2}{*}{$\begin{array}{l}\text { HCS Cycle } \\
\text { Time/Witness } \\
\text { Model }\end{array}$} & $\begin{array}{l}\text { Fuel } \\
\text { - Drying Curves } \\
\text { - } \mathrm{H}_{2} \mathrm{O} \text { Content } \\
\text { - Reaction } \\
\text { Kinetics } \\
\text { - Ignition } \\
\text { Potential } \\
\end{array}$ & $\begin{array}{l}\text { Fuel highlight reports have been produced } \\
\text { on a continual basis beginning September } 9 \text {, } \\
1995, \text { for KW fuel with the first major } \\
\text { deliverable due August 1996; similarly data } \\
\text { highlight reports are being produced on a } \\
\text { continual basis for KE fuel beginning May } \\
1996 \text { with the final report due August } 1997 \text {. }\end{array}$ & $8 / 96$ & $\begin{array}{l}\text { Thermal Hydraulic } \\
\text { Calibration Tests } 1,3\end{array}$ & $12 / 96^{2}$ & $12 / 96^{2}$ \\
\hline & $\begin{array}{l}\text { Sludge } \\
\text { - Drying Curves } \\
\text { - } \mathrm{H}_{2} 0 \text { Content } \\
\text { - Chemical } \\
\text { Content } \\
\text { - Particle Size } \\
\text { - Distribution }\end{array}$ & $\begin{array}{l}\text { The first data highlight report on KE floor } \\
\text { sludge was issued in January 1996, and the } \\
\text { first major report issued in April 1996; } \\
\text { similarly highlight reports are currently } \\
\text { being produced on KE canister sludge with } \\
\text { the first major report due March } 1997 \text {; } \\
\text { highlight reports on KW canister sludge } \\
\text { will follow with a major report due in May } \\
1997 \text {. }\end{array}$ & $8 / 96$ & & & \\
\hline
\end{tabular}

See attached Hot Conditioning System Test Program Overview.

2 Dates to be finalized in Test Plan.

${ }^{3}$ All tests are budgeted. 
Table B-1. Spent Nuclear Fuel Process Model Verification Matrix (12 Sheets).

Hot Vacuum Conditioning System - Spent Nuclear Fuel Process Model Verification Matrix (2 Sheets)

\begin{tabular}{||l|l|l|}
\hline \multicolumn{1}{|c|}{ End Point Criteria } & \multicolumn{1}{|c|}{ Basis } & \multicolumn{1}{c|}{ Interim Assumptions } \\
\hline $\begin{array}{l}\text { HCS } \\
\text { Total water content of } \mathrm{MCO}<1.67 \mathrm{Kg} \text { after } \\
\text { HCS. }\end{array}$ & Bounds pressure rise to $<150 \mathrm{psig}$. & $\mathrm{O}_{2}$ consumption potential $>\mathrm{O}_{2}$ produced. \\
\hline
\end{tabular}

\begin{tabular}{|l|l|l||}
\hline \multicolumn{1}{|c|}{ End Point Criteria } & \multicolumn{1}{|c|}{ Measurement } & \multicolumn{1}{|c|}{ Measurement Basis } \\
\hline $\begin{array}{l}\text { HCS } \\
\text { Total water content of MCO }<1.67 \mathrm{Kg} \text { after } \\
\text { HCS. }\end{array}$ & $\begin{array}{l}\text { Verify specified fuel conditioning profile has } \\
\text { been achieved. }\end{array}$ & $\begin{array}{l}\text { Fuel Characterization correlations show that } \\
\text { total water will be }<1.67 \mathrm{Kg} \text { after being } \\
\text { subjected to the HCS even with fuel } \\
\text { representing bounding worst case } \\
\text { constituents. }\end{array}$ \\
\hline
\end{tabular}


Table B-1. Spent Nuclear Fuel Process Model Verification Matrix (12 Sheets).

Hot Conditioning System Test Program Overview

\begin{tabular}{|c|c|c|c|c|}
\hline Process Tests & Description & Test Plan & Start & Finish \\
\hline $\begin{array}{l}\text { Process Equipment } \\
\text { Testing }\end{array}$ & $\begin{array}{l}\text { MCO internal filter load tests, vacuum pump tests, } \\
\text { heat ing/cooling system component tests to verify } \\
\text { applicability, accuracy, sizing, etc. }\end{array}$ & $\begin{array}{l}\text { Overall test plan to be issued } \\
\text { for review by } 8 / 2 / 96 \text {. }\end{array}$ & $10 / 96^{1}$ & $12 / 96^{\prime}$ \\
\hline $\begin{array}{l}\text { Thermal Hydraulic } \\
\text { Calibration Tests }\end{array}$ & $\begin{array}{l}\text { Identify system specific characteristics to calibrate } \\
\text { model variables. Heat up/cool down rates and } \\
\text { temperature distribution, gas flow distribution, } \\
\text { pump down rates and flow capacity. }\end{array}$ & $\begin{array}{l}\text { Overall test plan to be issued } \\
\text { for review by } 8 / 2 / 96 \text {. }\end{array}$ & $10 / 96^{1}$ & $12 / 96^{1}$ \\
\hline $\begin{array}{l}\text { System Response } \\
\text { Testing }\end{array}$ & $\begin{array}{l}\text { Perform integrated system testing. Included are } \\
\text { hydrogen concentration control, external/internal } \\
\text { temperature correlation, Process performance } \\
\text { relative to water removal, oxygen gettering } \\
\text { confirmation, and system response time tests. }\end{array}$ & $\begin{array}{l}\text { Overall test plan to be issued } \\
\text { for review by } 8 / 2 / 96 \text {. }\end{array}$ & $10 / 96^{\prime}$ & $12 / 96^{\prime}$ \\
\hline
\end{tabular}

${ }^{1}$ Dates are approximate; to be finalized in the Test Plan. 
Table B-1. Spent Nuclear Fuel Process Model Verification Matrix (12 Sheets).

Canister Storage Building Design Issued Requiring Post Design Verification and Validation

\begin{tabular}{|c|c|c|c|c|c|c|}
\hline \multirow[b]{2}{*}{$\begin{array}{c}\text { Issue/ } \\
\text { Verification }\end{array}$} & \multicolumn{3}{|c|}{ Design Calculation Support } & \multicolumn{3}{|c|}{ Process Verification } \\
\hline & Confirmatory Analysis & Date Available & $\begin{array}{c}\text { Date } \\
\text { Needed }\end{array}$ & $\begin{array}{c}\text { Process } \\
\text { Tests }\end{array}$ & $\begin{array}{l}\text { Date } \\
\text { Avail. }\end{array}$ & $\begin{array}{c}\text { Date } \\
\text { Needed }\end{array}$ \\
\hline $\begin{array}{l}\text { Confirmation that } 250^{\circ} \mathrm{F} \\
\text { maximum surface temperature of } \\
\text { MCO is acceptable design basis } \\
\text { (Thermal Analysis). }\end{array}$ & $\begin{array}{l}\text { Thermal Analysis of } \mathrm{MCO} \\
\text { internals for maximum fuel } \\
\text { temperature - Test Data to show } \\
\text { final fuel temperature acceptable, } \\
\text { corrosion, heat generation, } \mathrm{H}_{2} \\
\text { generation, etc. }\end{array}$ & $\begin{array}{l}\text { Part of MCO Topical } \\
\text { Report } 10 / 96\end{array}$ & $\begin{array}{l}12 / 96 \\
\text { (Support } \\
\text { SAR) }\end{array}$ & 1 & & \\
\hline $\begin{array}{l}\text { Confirmation surface dose when } \\
\text { MCO is in cask in service pit } \\
\text { does not exceed } 100 \mathrm{mr} / \mathrm{hr} \text { on } \\
\text { contact (Shielding/ALARA). }\end{array}$ & $\begin{array}{l}\text { Shielding analysis for } \mathrm{MCO} \text { in } \\
\text { cask with final MCO design, final } \\
\text { cask design, worst case fuel } \\
\text { loading. }\end{array}$ & MCO Final Design & $\begin{array}{l}\text { 12/96 SAR } \\
\text { Prep } \\
\text { 5/97 SAR } \\
\text { Approval } \\
\end{array}$ & 1 & & \\
\hline
\end{tabular}

I The Process Verification activities for staging at the CSB are covered under CVD Testing. The Process Verification activities for storage at the CSB are covered under HCS testing. 
Table B-1. Spent Nuclear Fuel Process Model Verification Matrix (12 Sheets).

Fuel Retrieval System - Spent Nuclear Fuel Process Model Verification Matrix

\begin{tabular}{|c|c|c|c|c|c|c|}
\hline \multirow[b]{2}{*}{$\begin{array}{c}\text { Issue/ } \\
\text { Verification Model }\end{array}$} & \multicolumn{3}{|c|}{ Design Calculation Support } & \multicolumn{3}{|c|}{ Process Verification } \\
\hline & Fuel Tests & $\begin{array}{c}\text { Date } \\
\text { Available }\end{array}$ & $\begin{array}{c}\text { Date } \\
\text { Needed }\end{array}$ & Process Tests & $\begin{array}{l}\text { Date } \\
\text { Avail. }\end{array}$ & $\begin{array}{c}\text { Date } \\
\text { Needed }\end{array}$ \\
\hline $\begin{array}{l}\text { Sludge Removal from Fuel } \\
\text { Exterior Surfaces, } \\
\text { Characterization/Design Validation } \\
\text { Tests }\end{array}$ & $\begin{array}{l}\text { In Basin Fuel Wash Tests } \\
\text { WHC-SD-SNF-TP- } 23^{1.2}\end{array}$ & $6 / 96$ & $6 / 96$ & $\begin{array}{l}\text { Primary Wash Development } \\
\text { Testing } \\
\text { WHC-SD-SNF-TP-027 1,2 }\end{array}$ & $8 / 96$ & $8 / 96$ \\
\hline
\end{tabular}

\begin{tabular}{|c|c|c|}
\hline End Point Criteria & Basis & Interim Assumptions \\
\hline $\begin{array}{l}\text { FRS } \\
\leq 16 \mathrm{~kg} \text { of sludge average per MCO. } \\
\text { WHC-SD-SNF-OCD-001 }\end{array}$ & Process control target. & $\begin{array}{l}\text { The Fuel Retrieval Subproject will qualify its } \\
\text { process by characterizing the cleaning } \\
\text { performance }\end{array}$ \\
\hline $\begin{array}{l}\text { Loaded residual organics controlled. } \\
\text { WHC-SD-SNF-OCD-001 }\end{array}$ & $\begin{array}{l}\text { Gas products from loaded organics shall not } \\
\text { produce more than } 10 \% \text { of the allowed MCO } \\
\text { pressure contingency. }\end{array}$ & $\begin{array}{l}\text { Less than one non-reactor debris item in } 50 \\
\text { canisters. These items can be visually identified } \\
\text { and separated from the fuel and irradiated debris. } \\
\text { (Letter, E. W. Gerber to B. S. Carlisle, 2C000-96- } \\
031 \text { ) }\end{array}$ \\
\hline End Point Criteria & Measurement & Measurement Basis \\
\hline$<16 \mathrm{~kg}$ of sludge average per $\mathrm{MCO}$ & $\begin{array}{l}\text { Visual examination of exterior fuel surfaces with } \\
\text { video cameras viewed without magnification from } \\
\text { a distance of } \leq 2 \mathrm{ft} \text {. (WHC-S-0461) }\end{array}$ & $\begin{array}{l}\text { Process validation methodology can be developed } \\
\text { using } 100 \% \text { inspection of } 50 \text { canisters then } \\
\text { inspection of one element in } 100 \text { throughout } \\
\text { process life. (Letter, E. W. Gerber to B. S. } \\
\text { Carlisle, 2C000-96-031) }\end{array}$ \\
\hline
\end{tabular}

All tests are budgeted.

${ }^{2}$ See attached Test Plan Overview. 
Table B-1. Spent Nuclear Fuel Process Model Verification Matrix (12 Sheets).

Fuel Retrieval Subproject Test Program Overview (2 Sheets).

\begin{tabular}{|c|c|c|c|c|}
\hline Fuel Tests & Description & Test Plan & Start & End \\
\hline \multirow[t]{2}{*}{$\begin{array}{l}\text { Inspect fuel in K East } \\
\text { canisters }\end{array}$} & $\begin{array}{l}\text { Inspection of visually degraded fuel to identify and } \\
\text { classify damage. }\end{array}$ & WHC-SD-SNF-TP-023 & $5 / 96$ & TBD \\
\hline & $\begin{array}{l}\text { Sampling and inspection of visually good fuel to } \\
\text { quantify damage estimates. }\end{array}$ & WHC-SD-SNF-TP-023 & $6 / 96$ & TBD \\
\hline \multirow[t]{4}{*}{$\begin{array}{l}\text { In-situ agitation of sludge } \\
\text { adhered to fuel elements }\end{array}$} & $\begin{array}{l}\text { Underwater fuel swinging and brushing of fuel } \\
\text { elements to evaluate range of sludge adherence. }\end{array}$ & WHC-SD-SNF-TP-023 & $6 / 96$ & $6 / 96$ \\
\hline & $\begin{array}{l}\text { Mechanical tumbling of elements to determine } \\
\text { mechanical interaction between elements. }\end{array}$ & WHC-SD-SNF-TP-023 & $6 / 96$ & $7 / 96$ \\
\hline & $\begin{array}{l}\text { End cap impact tests to determine ease of end } \\
\text { corrosion removal. }\end{array}$ & WHC-SD-SNF-TP-023 & TBD & TBD \\
\hline & $\begin{array}{l}\text { In-situ ultrasonic tests to determine effectiveness on } \\
\text { surface and imbedded sludge. }\end{array}$ & WHC-SD-SNF-TP-023 & TBD & TBD \\
\hline \multirow{3}{*}{$\begin{array}{l}\text { Hot-cell adhered sludge } \\
\text { tests }\end{array}$} & Quantify adhered film on shipped assemblies. & 327 Test Instruction & $6 / 96$ & TBD \\
\hline & Ultrasonic cleaning efficiency tests. & 327 Test Instruction & $6 / 96$ & TBD \\
\hline & $\begin{array}{l}\text { Adhered studge sampling for organic or bonding } \\
\text { agent. }\end{array}$ & 327 Test Instruction & $6 / 96$ & TBD \\
\hline
\end{tabular}


Table B-1. Spent Nuclear Fuel Process Model Verification Matrix (12 Sheets).

Fuel Retrieval Subproject Test Program Overview (2 Sheets).

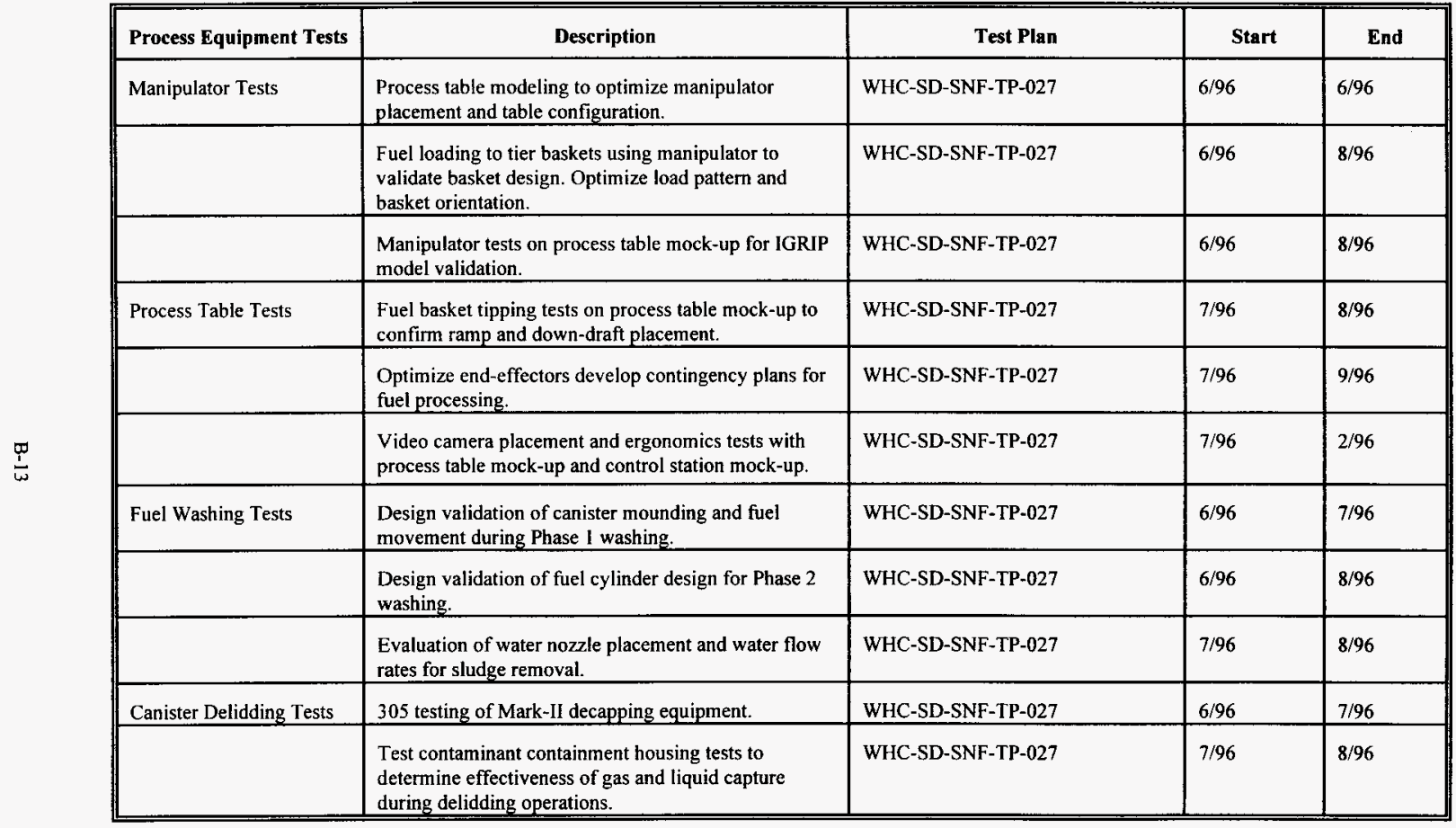


Table B-2. Spent Nuclear Fuel Safety Analysis Model Verification Matrix (8 Sheets).

Cold Vacuum Drying System Accident Analyses Matrix (2 Sheets).

\begin{tabular}{|c|c|c|c|c|c|c|}
\hline $\begin{array}{c}\text { Analysis } \\
\text { Models }\end{array}$ & Brief Description & $\begin{array}{c}\text { Data - Input to } \\
\text { Model }\end{array}$ & $\begin{array}{c}\text { Data to Validate } \\
\text { Model }\end{array}$ & $\begin{array}{c}\text { Verification Data } \\
\text { Available }\end{array}$ & $\begin{array}{c}\text { Need Date } \\
\text { for SAR }\end{array}$ & $\begin{array}{c}\text { Interim } \\
\text { Assumption }\end{array}$ \\
\hline $\begin{array}{l}\text { Fuel lgnition } \\
\text { and Reaction } \\
\text { Kinetics } \\
\text { Correlations } \\
\text { developed from } \\
\text { empirical data }\end{array}$ & $\begin{array}{l}\text { Fuel Reaction Rates } \\
\text { as a function of: } \\
\text { Temperature, } \\
\text { Humidity, Surface } \\
\text { Area. } \\
\text { Provides } \mathrm{H}_{2} \text { and } \mathrm{O}_{2} \\
\text { Generation and } \\
\text { Energy Release }\end{array}$ & $\begin{array}{l}\text { MCO Temperature } \\
\text { and Humidity } \\
\text { Ranges Conditions } \\
\text { During CVD Process }\end{array}$ & $\begin{array}{l}\text { Characterization TGA } \\
\text { Test Providing } \\
\text { Reaction Rates for } \\
\text { Damaged Fuel } \\
\text { - Verifies Bounding } \\
\quad \text { Reaction Rate }\end{array}$ & $\begin{array}{l}\text { Fuel highlight reports have } \\
\text { been produced on a continual } \\
\text { basis beginning September } 9 \text {, } \\
1995 \text { for KW fuel with the } \\
\text { first major deliverable due } \\
\text { August } 1996 \text {; similarly data } \\
\text { highlight reports are being } \\
\text { produced on a continual basis } \\
\text { for KE fuel beginning May } \\
1996 \text { with the final report due } \\
\text { August } 1997 \text {. }\end{array}$ & $\begin{array}{l}08 / 01 / 96 \\
\text { Chapter } 3 \\
03 / 97 \\
\text { Final } \\
\text { Submittal }\end{array}$ & $\begin{array}{l}\text { - Use Published } \\
\text { Data for Fuel } \\
\text { Reaction Rates } \\
\text { - Published data } \\
\text { will be rate- } \\
\text { adjusted to } \\
\text { account for } \\
\text { damaged fuel }\end{array}$ \\
\hline $\begin{array}{l}\text { MCO Release } \\
\text { - Thermal- } \\
\text { hydraulics } \\
\text { flow model } \\
\text { - Aerosol } \\
\text { transport } \\
\text { model }\end{array}$ & $\begin{array}{l}\text { Gas and Entrained } \\
\text { Particulates from } \\
\text { MCO as a Function } \\
\text { of: P, T, V and MCO } \\
\text { Contents, Particle } \\
\text { Size Distribution } \\
\text { Provides Quantity of } \\
\text { Gas and Particle } \\
\text { Releases }\end{array}$ & $\begin{array}{l}\text { Amount of } \\
\text { Particulate in MCO } \\
\text { on Arrival at CVD } \\
\text { system. (See Interim } \\
\text { Assumption 1) }\end{array}$ & $\begin{array}{l}\text { Particle Size } \\
\text { Distribution. (See } \\
\text { Interim Assumption 2) }\end{array}$ & $\begin{array}{l}\text { The first data highlight report } \\
\text { on KE floor sludge was issued } \\
\text { in January 1996, and the first } \\
\text { major report issued in April } \\
\text { 1996; similarly highlight } \\
\text { reports are currently being } \\
\text { produced on KE canister } \\
\text { sludge with the first major } \\
\text { report due March } 1997 \text {; } \\
\text { highlight reports on KW } \\
\text { canister sludge will follow } \\
\text { with a major report due in } \\
\text { May } 1997 \text {. }\end{array}$ & $\begin{array}{l}08 / 01 / 96 \\
\text { Chapter } 3 \\
03 / 97 \\
\text { Final } \\
\text { Submittal }\end{array}$ & $\begin{array}{l}\text { 1. } 277 \mathrm{~kg}^{\prime} \\
\text { particulate } \\
\text { 2. Log Normal } \\
\text { Distribution and } \\
\text { Handbook Data }\end{array}$ \\
\hline
\end{tabular}

1 Proposed safety envelope limit related to the MCO radioactive release accident analysis discussed in a letter from J. C. Fulton to C. A. Hansen on June 14, 1996 (Fulton 1996). The currently accepted assumption for MCO release is a sludge limit of $16 \mathrm{~kg}$ and $150 \mathrm{psig}$. 
Table B-2. Spent Nuclear Fuel Safety Analysis Model Verification Matrix (8 Sheets).

Cold Vacuum Drying System Accident Analyses Matrix (2 Sheets).

\begin{tabular}{|c|c|c|c|c|c|c|}
\hline $\begin{array}{l}\text { Analysis } \\
\text { Models }\end{array}$ & Brief Description & $\begin{array}{l}\text { Data - Input to } \\
\text { Model }\end{array}$ & $\begin{array}{c}\text { Data to Validate } \\
\text { Model }\end{array}$ & $\begin{array}{c}\text { Verification Data } \\
\text { Available }\end{array}$ & $\begin{array}{c}\text { Need Date } \\
\text { for SAR }\end{array}$ & $\begin{array}{c}\text { Interim } \\
\text { Assumption }\end{array}$ \\
\hline $\begin{array}{l}\text { MCO } \\
\text { Pressurization } \\
\text { - Radiolysis } \\
\text { rates } \\
\text { - Reaction } \\
\text { kinetics } \\
\text { model }\end{array}$ & $\begin{array}{l}\text { Determines Pressure } \\
\text { in MCO Based on } \\
\text { Fuel and Particulate } \\
\text { Content, Water } \\
\text { Content and External } \\
\text { Conditions - from } \\
\text { Corrosion and } \\
\text { Radiolysis } \\
\\
\text { - Provides Gas } \\
\text { Composition and } \\
\text { Generation Rates }\end{array}$ & $\begin{array}{l}\text { Volume of Free } \\
\text { Space in Water } \\
\text { Filled MCO, Fuel } \\
\text { Reaction Rates in } \\
100 \% \text { RH } \\
\text { Atmosphere (See } \\
\text { Fuel Ignition and } \\
\text { Reaction Kinetics) } \\
\\
\text { - Fuel Element } \\
\text { Loading and } \\
\text { Particulate } \\
\text { Content After Fuel } \\
\text { Loading in MCO }\end{array}$ & $\begin{array}{l}\text { - Validate with } \\
\text { Characterization } \\
\text { TGA Test } \\
\text { Providing Reaction } \\
\text { Rates for Damaged } \\
\text { Fuel (See Fuel } \\
\text { Ignition) } \\
\\
\text { - Verify/Model by } \\
\text { Peer Review and } \\
\text { Configuration } \\
\text { Control }\end{array}$ & $\begin{array}{l}\text { Fuel highlight reports have } \\
\text { been produced on a continual } \\
\text { basis beginning September } 9 \text {, } \\
1995 \text { for KW fuel with the } \\
\text { first major deliverable due } \\
\text { August 1996; similarly data } \\
\text { highlight reports are being } \\
\text { produced on a continual basis } \\
\text { for KE fuel beginning May } \\
1996 \text { with the final report due } \\
\text { August } 1997 \text {. } \\
\text { - } 6 / 96\end{array}$ & $\begin{array}{l}08 / 96 \\
08 / 96\end{array}$ & $\begin{array}{l}\text { Each MCO will be } \\
\text { qualified for } \\
\text { transportation by } \\
\text { direct measurement } \\
\text { of pressure } \\
\text { behavior }\end{array}$ \\
\hline $\begin{array}{l}\text { Hydrogen } \\
\text { Detonation and } \\
\text { Deflagration }\end{array}$ & $\begin{array}{l}\text { Determines Oxygen- } \\
\text { Hydrogen Ratio at } \\
\text { Which Detonation or } \\
\text { Deflagration will } \\
\text { Occur and the } \\
\text { Transient Behavior } \\
\text { as a Function of } \\
\text { Confining Geometry }\end{array}$ & $\begin{array}{l}\text { - Initial Condition } \\
\text { of Hydrogen } \\
\text { Content and } \\
\text { Generation Rate - } \\
\text { From Reaction } \\
\text { Kinetics } \\
\text { - Oxygen: } \\
\text { Availability Rate } \\
\text { - MCO and CVD } \\
\text { System Design } \\
\text { Configuration }\end{array}$ & Peer Review & Not Required & $08 / 96$ & $\begin{array}{l}\text { - Hydrogen } \\
\text { Constituents } \\
\text { from Worst } \\
\text { Case Reaction } \\
\text { Rate } \\
\text { - Oxygen } \\
\text { Constituents } \\
\text { from Worst } \\
\text { Case Accident } \\
\text { Scenario } \\
\text { MCO and CVD } \\
\text { Definitive } \\
\text { Design Detail }\end{array}$ \\
\hline
\end{tabular}


Table B-2. Spent Nuclear Fuel Safety Analysis Model Verification Matrix (8 Sheets).

Canister Storage Building Accident Analyses Matrix (3 Sheets)

\begin{tabular}{|c|c|c|c|c|c|c|}
\hline $\begin{array}{c}\text { Analysis } \\
\text { Models }\end{array}$ & Brief Description & $\begin{array}{c}\text { Data - Input to } \\
\text { Model }\end{array}$ & $\begin{array}{c}\text { Data to Validate } \\
\text { Model }\end{array}$ & Verification Data Available & $\begin{array}{c}\text { Need Date } \\
\text { for SAR }\end{array}$ & $\begin{array}{c}\text { Interim } \\
\text { Assumption }\end{array}$ \\
\hline $\begin{array}{l}\text { Fuel Ignition } \\
\text { and Reaction } \\
\text { Kinetics } \\
\text { - Correlations } \\
\quad \text { from } \\
\text { empirical } \\
\text { data }\end{array}$ & $\begin{array}{l}\text { Fuel Reaction Rates } \\
\text { as a Function of: } \\
\text { Temperature, } \\
\text { Humidity, Surface } \\
\text { Area } \\
\text { Provides } \mathrm{H}_{2} \text { and } \mathrm{O}_{2} \\
\text { Generation }\end{array}$ & $\begin{array}{l}\text { MCO } \\
\text { Temperature and } \\
\text { Humidity Ranges } \\
\text { for Steady State } \\
\text { Condition in CSB } \\
\text { Staging }\end{array}$ & $\begin{array}{l}\text { - Characterization } \\
\text { TGA Test } \\
\text { Providing Reaction } \\
\text { Rates for Damaged } \\
\text { Fuel } \\
\text { - Verifies Bounding } \\
\text { Reaction Rate }\end{array}$ & $\begin{array}{l}\text { Fuel highlight reports have } \\
\text { been produced on a continual } \\
\text { basis beginning September } 9 \text {, } \\
1995 \text { for KW fuel with the } \\
\text { first major deliverable due } \\
\text { August 1996; similarly data } \\
\text { highlight reports are being } \\
\text { produced on a continual basis } \\
\text { for KE fuel beginning May } \\
\text { I996 with the final report due } \\
\text { August } 1997 \text {. }\end{array}$ & $\begin{array}{l}08 / 01 / 96 \\
\text { Chapter } 3 \\
03 / 97 \\
\text { Final } \\
\text { Submittal }\end{array}$ & $\begin{array}{l}\text { Use Published } \\
\text { Data for Fuel } \\
\text { Reaction Rates } \\
\text { Published data } \\
\text { will be rate- } \\
\text { adjusted to } \\
\text { account for } \\
\text { damaged fuel }\end{array}$ \\
\hline $\begin{array}{l}\text { MCO Release } \\
\text { - Thermal- } \\
\text { hydraulics } \\
\text { model } \\
\text { - Aerosol } \\
\text { transport } \\
\text { model }\end{array}$ & $\begin{array}{l}\text { Gas and Entrained } \\
\text { Particulates from } \\
\text { MCO as a Function } \\
\text { of: P, T, V and MCO } \\
\text { Contents, Particle } \\
\text { Size Distribution } \\
\text { Provides Quantity of } \\
\text { Gas and Particle } \\
\text { Releases }\end{array}$ & $\begin{array}{l}\text { Amount of } \\
\text { Particulate in } \\
\text { MCO on Arrival } \\
\text { at CSB, After } \\
5 \text { Year Staging } \\
\text { and in Storage. } \\
\text { See (Interim } \\
\text { Assumption 1) }\end{array}$ & $\begin{array}{l}\text { Particle Size } \\
\text { Distribution. (See } \\
\text { Interim Assumption } \\
\text { 2) }\end{array}$ & $\begin{array}{l}\text { The first data highlight report } \\
\text { on KE floor sludge was issued } \\
\text { in January 1996, and the first } \\
\text { major report issued in April } \\
1996 \text {; similarly highlight } \\
\text { reports are currently being } \\
\text { produced on KE canister } \\
\text { sludge with the first major } \\
\text { report due March 1997; } \\
\text { highlight reports on KW } \\
\text { canister sludge will follow } \\
\text { with a major report due in } \\
\text { May } 1997 \text {. }\end{array}$ & $\begin{array}{l}08 / 01 / 96 \\
\text { Chapter } 3 \\
\\
03 / 97 \\
\text { Final } \\
\text { Submittal }\end{array}$ & $\begin{array}{l}\text { 1. Staging - } \\
277 \mathrm{~kg}^{1} \\
\text { particulate and } \\
25 \mathrm{psi}^{\prime} \\
\text { - Storage } 1.67 \mathrm{~kg} \\
\text { retained bound } \\
\text { water upon } \\
\text { MCO sealing } \\
\text { 2. Log Normal } \\
\text { Distribution } \\
\text { and Handbook } \\
\text { Data }\end{array}$ \\
\hline
\end{tabular}

: Proposed safety envelope limit related to the MCO radioactive release accident analysis discussed in a letter from J. C. Fulton to C. A. Hansen on June 14, 1996 (Fulton 1996). The currently accepted assumption for MCO release is a sludge limit of $16 \mathrm{~kg}$ and $150 \mathrm{psig}$. 
Table B-2. Spent Nuclear Fuel Safety Analysis Model Verification Matrix (8 Sheets).

Canister Storage Building Accident Analyses Matrix (3 Sheets)

\begin{tabular}{|c|c|c|c|c|c|c|}
\hline $\begin{array}{l}\text { Analysis } \\
\text { Models }\end{array}$ & Brief Description & $\begin{array}{c}\text { Data - Input to } \\
\text { Model }\end{array}$ & $\begin{array}{c}\text { Data to Validate } \\
\text { Model } \\
\end{array}$ & Verification Data Available & $\begin{array}{c}\text { Need Date } \\
\text { for SAR }\end{array}$ & $\begin{array}{c}\text { Interim } \\
\text { Assumption } \\
\end{array}$ \\
\hline $\begin{array}{l}\text { MCO } \\
\text { Pressurization } \\
\text { - } \begin{array}{l}\text { Radiolysis } \\
\text { rates }\end{array} \\
\text { - Fuel } \\
\text { corrosion } \\
\text { reaction } \\
\text { kinetics } \\
\text { model }\end{array}$ & $\begin{array}{l}\text { Determines Pressure } \\
\text { in MCO From } \\
\text { Corrosion and } \\
\text { Radiolysis Based on } \\
\text { Fuel and Particulate } \\
\text { Content, Water } \\
\text { Content and External } \\
\text { Conditions } \\
\text { - Provides Gas } \\
\text { Composition and } \\
\text { Generation Rates }\end{array}$ & $\begin{array}{l}\text { Water Content, } \\
\text { Fuel Reaction } \\
\text { Rates (See Fuel } \\
\text { Ignition and } \\
\text { Reaction Kinetics) } \\
\text { - Fuel Element } \\
\text { Loading and } \\
\text { Particulate } \\
\text { Content at } \\
\text { Receiving and } \\
\text { During Staging }\end{array}$ & $\begin{array}{l}\text { - Validate with } \\
\text { Characterization } \\
\text { TGA Test } \\
\text { Providing Reaction } \\
\text { Rates for Damaged } \\
\text { Fuel (See Fuel } \\
\text { Ignition) } \\
\text { - Verify/Model by } \\
\text { Peer Review and } \\
\text { Configuration } \\
\text { Control } \\
\text { - MCO Water } \\
\text { Content at } \\
\text { Receiving and } \\
\text { During Staging }\end{array}$ & $\begin{array}{l}\text { Fuel highlight reports have } \\
\text { been produced on a continual } \\
\text { basis beginning September } 9 \text {, } \\
1995 \text { for KW fuel with the } \\
\text { first major deliverable due } \\
\text { August } 1996 \text {; similarly data } \\
\text { highlight reports are being } \\
\text { produced on a continual basis } \\
\text { for KE fuel beginning May } \\
1996 \text { with the final report due } \\
\text { August } 1997 \text {. }\end{array}$ & $\begin{array}{l}08 / 96 \\
08 / 96 \\
03 / 97 \\
\text { Final } \\
\text { Submittal }\end{array}$ & $\begin{array}{l}1.67 \mathrm{~kg} \\
\text { retained bound } \\
\text { water upon } \\
\text { MCO sealing }\end{array}$ \\
\hline
\end{tabular}


Table B-2. Spent Nuclear Fuel Safety Analysis Model Verification Matrix (8 Sheets).

Canister Storage Building Accident Analyses Matrix (3 Sheets)

\begin{tabular}{|c|c|c|c|c|c|c|}
\hline $\begin{array}{c}\text { Analysis } \\
\text { Models }\end{array}$ & Brief Description & $\begin{array}{c}\text { Data - Input to } \\
\text { Model }\end{array}$ & $\begin{array}{c}\text { Data to Validate } \\
\text { Model }\end{array}$ & Verification Data Available & $\begin{array}{c}\text { Need Date } \\
\text { for SAR }\end{array}$ & $\begin{array}{c}\text { Interim } \\
\text { Assumption }\end{array}$ \\
\hline $\begin{array}{l}\text { Hydrogen } \\
\text { Detonation and } \\
\text { Deflagration } \\
\text { - Radiolysis } \\
\text { rates } \\
\text { - Fuel } \\
\text { corrosion } \\
\text { reaction } \\
\text { kinetics } \\
\text { model }\end{array}$ & $\begin{array}{l}\text { Determines Oxygen- } \\
\text { Hydrogen Ratio at } \\
\text { Which Detonation or } \\
\text { Deflagration will } \\
\text { Occur and the } \\
\text { Transient Behavior } \\
\text { as a Function of } \\
\text { Confining Geometry }\end{array}$ & $\begin{array}{l}\text { - Initial Condition } \\
\text { of Hydrogen } \\
\text { Content and } \\
\text { Generation Rate - } \\
\text { From Reaction } \\
\text { Kinetics Model } \\
\text { - Oxygen: } \\
\text { Generation and } \\
\text { Consumption Rate } \\
\text { - CSB Design } \\
\text { Configuration }\end{array}$ & $\begin{array}{l}\text { Peer Review } \\
\text { Radiolysis Rate for } \\
\text { MCO Contents }\end{array}$ & Not Required & $08 / 96$ & $\begin{array}{l}\text { - Hydrogen } \\
\text { Constituents } \\
\text { from Worst } \\
\text { Case Reaction } \\
\text { Rate } \\
\text { - Oxygen } \\
\text { Constituents } \\
\text { from Worst } \\
\text { Case Accident } \\
\text { Scenario } \\
\text { CSB Definitive } \\
\text { Design Detail }\end{array}$ \\
\hline
\end{tabular}


Table B-2. Spent Nuclear Fuel Safety Analysis Model Verification Matrix (8 Sheets).

Hot Conditioning System Accident Analyses Matrix (3 Sheets)

\begin{tabular}{|c|c|c|c|c|c|c|}
\hline $\begin{array}{c}\text { Analysis } \\
\text { Models }\end{array}$ & Brief Description & $\begin{array}{c}\text { Data - Input to } \\
\text { Model } \\
\end{array}$ & $\begin{array}{c}\text { Data to Validate } \\
\text { Model } \\
\end{array}$ & Verification Data Available & $\begin{array}{c}\text { Need Date } \\
\text { for SAR }\end{array}$ & $\begin{array}{c}\text { Interim } \\
\text { Assumption }\end{array}$ \\
\hline $\begin{array}{l}\text { Fuel Ignition } \\
\text { and Reaction } \\
\text { Kinetics } \\
\text { - Correlations } \\
\text { from } \\
\text { empirical } \\
\text { data }\end{array}$ & $\begin{array}{l}\text { Fuel Reaction Rates } \\
\text { as a Function of: } \\
\text { Temperature, } \\
\text { Humidity, Surface } \\
\text { Area } \\
\text { Provides } \mathrm{H}_{2} \text { and } \mathrm{O}_{2} \\
\text { Generation }\end{array}$ & $\begin{array}{l}\text { - MCO } \\
\text { Temperature and } \\
\text { Humidity Ranges } \\
\text { for Steady State } \\
\text { Condition in CSB } \\
\text { Staging }\end{array}$ & $\begin{array}{l}\text { Characterization } \\
\text { TGA Test } \\
\text { Providing Reaction } \\
\text { Rates for Damaged } \\
\text { Fuel } \\
\text { - Verifies Bounding } \\
\text { Reaction Rate }\end{array}$ & $\begin{array}{l}\text { Fuel highlight reports have } \\
\text { been produced on a continual } \\
\text { basis beginning September } 9 \text {, } \\
1995 \text { for KW fuel with the } \\
\text { first major deliverable due } \\
\text { August 1996; similarly data } \\
\text { highlight reports are being } \\
\text { produced on a continual basis } \\
\text { for KE fuel beginning May } \\
1996 \text { with the final report due } \\
\text { August } 1997 \text {. }\end{array}$ & $\begin{array}{l}\text { Chapter 3: } \\
\text { TBD } \\
\text { Final } \\
\text { Submittal: } \\
\text { TBD }\end{array}$ & $\begin{array}{l}\text { - Use Published } \\
\text { Data for Various } \\
\text { Fuel Reaction } \\
\text { Rates } \\
\text { - Published data } \\
\text { will be rate- } \\
\text { adjusted to } \\
\text { account for } \\
\text { damaged fuel }\end{array}$ \\
\hline 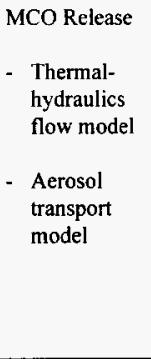 & $\begin{array}{l}\text { Gas and Entrained } \\
\text { Particulates from } \\
\text { MCO as a Function } \\
\text { of: P, T, V and MCO } \\
\text { Contents, Particle } \\
\text { Size Distribution } \\
\text { Provides Quantity of } \\
\text { Gas and Particle } \\
\text { Releases }\end{array}$ & $\begin{array}{l}\text { Amount of } \\
\text { Particulate in } \\
\text { MCO on Arrival } \\
\text { at CSB, After } \\
5 \text { Year Staging } \\
\text { and Hot } \\
\text { Conditioning. } \\
\text { (See Interim } \\
\text { Assumption 1) }\end{array}$ & $\begin{array}{l}\text { Particle Size } \\
\text { Distribution } \\
\text { (See Interim } \\
\text { Assumption 2) }\end{array}$ & $\begin{array}{l}\text { The first data highlight report } \\
\text { on KE floor sludge was issued } \\
\text { in January 1996, and the first } \\
\text { major report issued in April } \\
\text { 1996; similarly highlight } \\
\text { reports are currently being } \\
\text { produced on KE canister } \\
\text { sludge with the first major } \\
\text { report due March 1997; } \\
\text { highlight reports on KW } \\
\text { canister sludge will follow } \\
\text { with a major report due in } \\
\text { May } 1997 \text {. }\end{array}$ & $\begin{array}{l}\text { Chapter 3: } \\
\text { TBD } \\
\text { Final } \\
\text { Submittal: } \\
\text { TBD }\end{array}$ & $\begin{array}{l}\text { 1. } 277 \mathrm{~kg}^{\prime} \\
\text { particulate and } \\
25 \mathrm{psi}^{\mathrm{I}} \\
\text { 2. Log Normal } \\
\text { Distribution and } \\
\text { Handbook Data }\end{array}$ \\
\hline
\end{tabular}

1 Proposed safety envelope limit related to the MCO radioactive release accident analysis discussed in a letter from J. C. Fulton to C. A. Hansen on June 14, 1996 (Fulton 1996). The currently accepted assumption for MCO release is a sludge limit of $16 \mathrm{~kg}$ and $150 \mathrm{psig}$. 
Table B-2. Spent Nuclear Fuel Safety Analysis Model Verification Matrix (8 Sheets).

Hot Conditioning System Accident Analyses Matrix (3 Sheets)

\begin{tabular}{|c|c|c|c|c|c|c|}
\hline $\begin{array}{c}\text { Analysis } \\
\text { Models }\end{array}$ & Brief Description & $\begin{array}{c}\text { Data - Input to } \\
\text { Model }\end{array}$ & $\begin{array}{c}\text { Data to Validate } \\
\text { Model }\end{array}$ & Verification Data Available & $\begin{array}{c}\text { Need Date } \\
\text { for SAR }\end{array}$ & $\begin{array}{c}\text { Interim } \\
\text { Assumption }\end{array}$ \\
\hline $\begin{array}{l}\text { MCO } \\
\text { Pressurization } \\
\text { - Radiolysis } \\
\text { rates } \\
\text { - Fuel } \\
\text { corrosion } \\
\text { reaction } \\
\text { kinetics } \\
\text { model } \\
\text { - MCO } \\
\text { thermal } \\
\text { model }\end{array}$ & $\begin{array}{l}\text { Determines Pressure } \\
\text { in MCO From } \\
\text { Corrosion and } \\
\text { Radiolysis Based on } \\
\text { Fuel and Particulate } \\
\text { Content, Water } \\
\text { Content and External } \\
\text { Conditions } \\
\text { - Provides Gas } \\
\text { Composition and } \\
\text { Generation Rates }\end{array}$ & $\begin{array}{l}\text { - Water Content, } \\
\text { Fuel Reaction } \\
\text { Rates (See Fuel } \\
\text { Ignition and } \\
\text { Reaction Kinetics) } \\
\\
\text { - Fuel Element } \\
\text { Loading and } \\
\text { Particulate } \\
\text { Content at } \\
\text { Receiving, During } \\
\text { Staging and After } \\
\text { Hot Conditioning }\end{array}$ & $\begin{array}{l}\text { - Validate with } \\
\text { Characterization } \\
\text { TGA Test } \\
\text { Providing Reaction } \\
\text { Rates for Damaged } \\
\text { Fuel (See Fuel } \\
\text { Ignition) } \\
\text { - Verify/Model by } \\
\text { Peer Review and } \\
\text { Configuration } \\
\text { Control } \\
\\
\text { MCO Water } \\
\text { Content at } \\
\text { Receiving, During } \\
\text { Staging and After } \\
\text { Hot Conditioning } \\
\end{array}$ & $\begin{array}{l}\text { Fuel highlight reports have } \\
\text { been produced on a continual } \\
\text { basis beginning September } 9 \text {, } \\
1995 \text { for KW fuel with the } \\
\text { first major deliverable due } \\
\text { August 1996; similarly data } \\
\text { highlight reports are being } \\
\text { produced on a continual basis } \\
\text { for KE fuel beginning May } \\
1996 \text { with the final report due } \\
\text { August } 1997 \text {. }\end{array}$ & $\begin{array}{l}\text { Final } \\
\text { Submittal: } \\
\text { TBD }\end{array}$ & $\begin{array}{l}1.67 \mathrm{~kg} \text { retained } \\
\text { bound water upon } \\
\text { MCO sealing }\end{array}$ \\
\hline
\end{tabular}


Table B-2. Spent Nuclear Fuel Safety Analysis Model Verification Matrix (8 Sheets).

Hot Conditioning System Accident Analyses Matrix (3 Sheets)

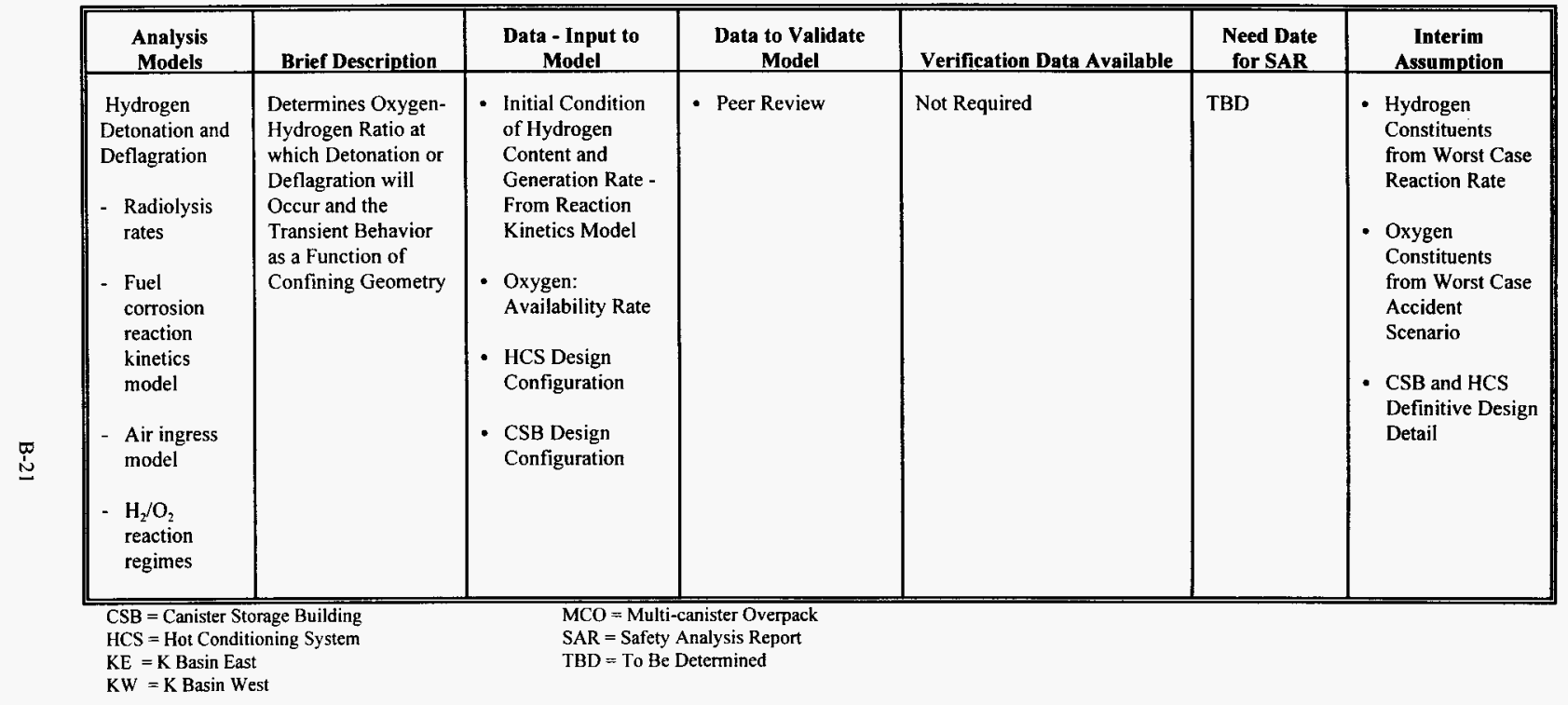


Table B-3. Major Technology Acquisition Reports (7 Sheets).

\begin{tabular}{|c|c|c|c|c|}
\hline & Report & $\begin{array}{c}\text { Date } \\
\text { Available }\end{array}$ & Report Scope & $\begin{array}{l}\text { Safety Analysis Being Supported } \\
\text { (From Table B-2) }\end{array}$ \\
\hline T-1a. & $\begin{array}{l}\text { Spent Nuclear Fuel Project Integrated Test } \\
\text { Strategy (Comprehensive test program), } \\
\text { WHC-SD-SNF-CM-004 } \\
\text { (WHC 1996a)(BCWD142A) } \\
\text { Spent Nuclear Fuel Project Integrated Test } \\
\text { Strategy, WHC-SD-SNF-CM-004 Rev.l } \\
\text { (WHC 1996b)(BCWD143A) } \\
\text { Spent Nuclear Fuel Project Technical Issue } \\
\text { Closure Strategy (TRI 1995) } \\
\text { MCO Topical Report }\end{array}$ & $\begin{array}{l}2 / 96 \\
8 / 96 \\
10 / 95 \\
10 / 96\end{array}$ & $\begin{array}{l}\text { A preliminary test integration } \\
\text { strategy for the SNF Project. } \\
\text { Integrated test strategy based } \\
\text { upor, design and safety data } \\
\text { needs. } \\
\text { A planning/strategy document } \\
\text { for technical issue closure. } \\
\text { Technical basis for MCO } \\
\text { through all subprojects. }\end{array}$ & $\begin{array}{l}\mathrm{H}_{2} \text { Deflagration (D.B.A. - CSB, CVD, HCS) } \\
\text { Air Ingress Model } \\
\text { Radiolysis rates } \\
\text { Reaction Kinetics Model } \\
\mathrm{H}_{2}-\mathrm{O}_{2} \text { Reaction Regimes } \\
\text { MCO Pressurization (D.B.A. - CSB, CVD) } \\
\text { Radiolysis rates } \\
\text { Reaction Kinetics Model } \\
\text { Rapid Fuel Oxidation (D.B.A. - CVD, HCS) } \\
\text { Fuel ignition and reaction kinetics } \\
\text { Empirical data correlations } \\
\text { MCO Overheating (D.B.A. - HCV) } \\
\text { Reaction Kinetics Model } \\
\text { MCO Release } \\
\text { Thermal Hydraulics Flow Model } \\
\text { Aerosol Transport Model }\end{array}$ \\
\hline $\mathrm{T}-6$. & $\begin{array}{l}\text { Technology Status in Support of Refined } \\
\text { Technical Baseline for the SNFP, } \\
\text { WHC-SD-TI-014 (WHC 1995a) } \\
\text { Spent Nuclear Fuel Project Technical } \\
\text { Databook (TDB), WHC-SD-SNF-TI-015 } \\
\text { (WHC 1995b) } \\
\text { Compile TDB for SAR Data (BCS410) } \\
\text { Characterization Data Report (Logic) } \\
\text { (BC410a25) }\end{array}$ & $\begin{array}{l}7 / 95 \\
10 / 95 \\
8 / 95 \\
2 / 96 \\
8 / 96 \\
8 / 96\end{array}$ & $\begin{array}{l}\text { Summarize analytic and } \\
\text { modeling data on technology } \\
\text { issues. } \\
\text { Accumulation of project level } \\
\text { safety and design bases technical } \\
\text { data. } \\
\text { Same as above } \\
\text { Desludging/repackaging, } \\
\text { vacuum drying/staging analysis; } \\
\text { integrate technical data; MCO } \\
\text { decay heat/rad nuc loading, irrad } \\
\text { uranium in air/water vapor/water } \\
\text { reaction rates; sludge drying } \\
\text { curve estimates, sludge drying } \\
\text { curve confirm, confirm all } \\
\text { assumptions; roll into TDB }\end{array}$ & $\begin{array}{l}\mathrm{H}_{2} \text { Deflagration (D.B.A. - CSB, CVD, HCS) } \\
\text { MCO Pressurization (D.B.A. - CSB, CVD) } \\
\text { Rapid Fuel Oxidation (D.B.A. - CVD, HCS) } \\
\text { MCO Overheating (D.B.A. - HCV) } \\
\text { MCO Release }\end{array}$ \\
\hline
\end{tabular}


Table B-3. Major Technology Acquisition Reports (7 Sheets).

\begin{tabular}{|c|c|c|c|c|}
\hline & Report & $\begin{array}{c}\text { Date } \\
\text { Available }\end{array}$ & Report Scope & $\begin{array}{l}\text { Safety Analysis Being Supported } \\
\text { (From Table B-2) }\end{array}$ \\
\hline $\begin{array}{l}\text { T-8. } \\
\text { T-9. }\end{array}$ & $\begin{array}{l}\text { Spent Nuclear Fuel Gas Generation Rates } \\
\text { Spent Nuclear Fuel Containers, } \\
\text { WHC-SD-SNF-TI-TBD } \\
\text { Fission Product Gas Release }\end{array}$ & $6 / 96$ & $\begin{array}{l}\text { Summarizes the earlier studies } \\
\text { on gas generation rates for } \\
\text { MCOs. }\end{array}$ & $\begin{array}{l}\mathrm{H}_{2} \text { Deflagration (D.B.A. - CSB, CVD, HCS) } \\
\text { MCO Pressurization (D.B.A. - CSB, CVD) } \\
\text { Rapid Fuel Oxidation (D.B.A. - CVD, HCS) }\end{array}$ \\
\hline $\mathrm{T}-10$. & $\begin{array}{l}\text { Jouget Detonation Pressure Estimates For } \\
\text { Hydrogen-Oxygen-Diluent Mixtures } \\
\text { Occurring in the Multi-Canister Overpack }\end{array}$ & $2 / 96$ & $\begin{array}{l}\text { Detonation model development } \\
\text { for the } \mathrm{MCO} \text {. }\end{array}$ & $\begin{array}{l}\mathrm{H}_{2} \text { Deflagration (D.B.A. - CSB, CVD, HCS) } \\
\text { MCO Pressurization (D.B.A. - CSB, CVD) }\end{array}$ \\
\hline$T-11$. & $\begin{array}{l}\text { Spent Nuclear Fuel Project Detonation } \\
\text { Phenomena of Hydrogen/Oxygen in Spent } \\
\text { Fuel Containers, WHC-SD-SNF-TI-021 } \\
\text { (WHC 1996c) (BCWC813X) }\end{array}$ & $5 / 96$ & $\begin{array}{l}\text { Assesses the key factors } \\
\text { affecting hydrogen detonation } \\
\text { within the MCO. Identifies } \\
\text { scenario where detonation is } \\
\text { possible. }\end{array}$ & · \\
\hline T-12. & $\begin{array}{l}\text { MCO Hydrogen Generation Safety Analysis } \\
\text { Assumption Confirmation (BCWC816X) }\end{array}$ & $1 / 97$ & $\begin{array}{l}\text { Confirm hydrogen safety } \\
\text { analysis assumptions based upon } \\
\text { process testing. }\end{array}$ & \\
\hline T-13. & $\begin{array}{l}\text { K Basin Corrosion Program Report, } \\
\text { WHC-EP-0877 (WHC 1995c) }\end{array}$ & $9 / 95$ & Empirical data on fuel corrosion. & $\begin{array}{l}\mathrm{H}_{2} \text { Deflagration (D.B.A. - CSB, CVD, HCS) } \\
\text { MCO Pressurization (D.B.A. - CSB, CVD) }\end{array}$ \\
\hline
\end{tabular}


Table B-3. Major Technology Acquisition Reports (7 Sheets).

\begin{tabular}{|c|c|c|c|c|}
\hline & Report & $\begin{array}{c}\text { Date } \\
\text { Available }\end{array}$ & Report Scope & $\begin{array}{l}\text { Safety Analysis Being Supported } \\
\text { (From Table B-2) }\end{array}$ \\
\hline T-14. & $\begin{array}{l}\text { Fuel Corrosion and Gas Evolution During } \\
\text { Retrieval, Transportation and Wet-Fuel } \\
\text { Staging (WHC 1995d) }\end{array}$ & $3 / 95$ & $\begin{array}{l}\text { Preliminary fuel corrosion rate, } \\
\text { gas evolution for retrieval, } \\
\text { transport and wet fuel staging. }\end{array}$ & $\begin{array}{l}\text { Air Ingress (BDBA - CSB, CVD) } \\
\mathrm{H}_{2} \text { Deflagration (D.B.A. - CSB, CVD, HCS) } \\
\text { MCO Pressurization (D.B.A. - CSB, CVD) } \\
\text { Rapid Fuel Oxidation (D.B.A. - CVD, HCS) }\end{array}$ \\
\hline T-15. & $\begin{array}{l}\text { Technical Bases for Assessing Fuel and } \\
\text { Sludge Behavior and Gas Release in an } \\
\text { MCO During Dry Fuel Storage } \\
\text { (SAIC 1995a) }\end{array}$ & $4 / 95$ & $\begin{array}{l}\text { MCO dry fuel storage } \\
\text { performance; fuel and sludge } \\
\text { behavior, gas release. }\end{array}$ & MCO Overheating (D.B.A. - HCV) \\
\hline T-16. & $\begin{array}{l}\text { Surface Area Consideration for Corroding } \\
\text { N Reactor Fuel (PNNL 1996a) }\end{array}$ & $3 / 96$ & $\begin{array}{l}\text { Evaluation of the affect of } \\
\text { surface area on potential uranium } \\
\text { corrosion rates. }\end{array}$ & \\
\hline T-17. & $\begin{array}{l}\text { Reaction Rate Data for Safety Analysis } \\
\text { (WHC 1995e) }\end{array}$ & $10 / 95$ & $\begin{array}{l}\text { Preliminary uranium fuel } \\
\text { reaction rate data for initial } \\
\text { safety bases analysis. }\end{array}$ & \\
\hline T-18. & $\begin{array}{l}\text { Recommended Reaction Rate Constants For } \\
\text { Corrosion of N Reactor Fuel, } \\
\text { WHC-SD-SNF-TI-020 (WHC 1996d) }\end{array}$ & $5 / 96$ & $\begin{array}{l}\text { Recommends uranium reaction } \\
\text { rates for design and safety basis } \\
\text { until characterization data on } \\
\text { actual fuel is available. }\end{array}$ & \\
\hline T-19. & $\begin{array}{l}\text { Surface Area Estimate for N-Fuel in } \\
\text { K East Basin, WHC-SD-SNF-TI-026 } \\
\text { (WHC 1996e) }\end{array}$ & $7 / 96$ & & \\
\hline $\mathrm{T}-20$. & $\begin{array}{l}\text { MCO Chemical Corrosion Safety Analysis } \\
\text { Confirmation,(BCWC716X) }\end{array}$ & $11 / 96$ & $\begin{array}{l}\text { Surface area closure strategy, } \\
\text { radial and isotopic elemental } \\
\text { dist., estimated products of } \\
\text { release, corrosion rates. }\end{array}$ & \\
\hline $\mathrm{T}-21$. & $\begin{array}{l}\text { Materials Guidance for Spent Nuclear Fuel } \\
\text { Multi-Canister Overpack (SAIC 1995b) }\end{array}$ & $4 / 95$ & $\begin{array}{l}\text { Material of construction } \\
\text { technical evaluation. }\end{array}$ & $\begin{array}{l}\text { MCO Pressurization (D.B.A. - CSB) } \\
\text { MCO Overheating (D.B.A. - HCV) }\end{array}$ \\
\hline T-22. & $\begin{array}{l}\text { Structural Integrity of the Spent Nuclear Fuel } \\
\text { Multi-Canister Overpack, WHC-SD-SNF- } \\
\text { ES-015 (WHC 1995f) }\end{array}$ & $5 / 95$ & $\begin{array}{l}\text { MCO structural integrity } \\
\text { assessment. }\end{array}$ & \\
\hline
\end{tabular}


Table B-3. Major Technology Acquisition Reports (7 Sheets).

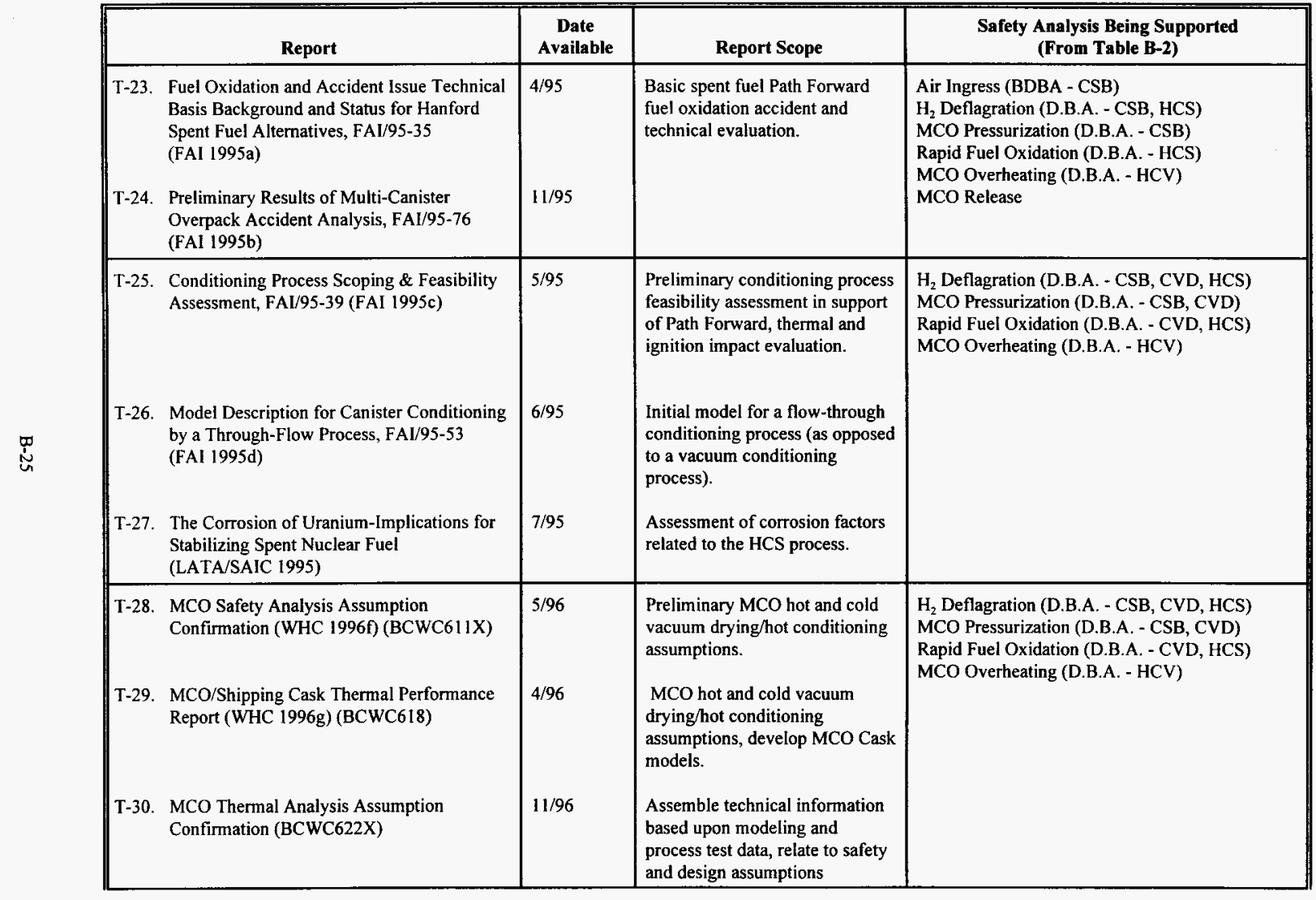


Table B-3. Major Technology Acquisition Reports (7 Sheets).

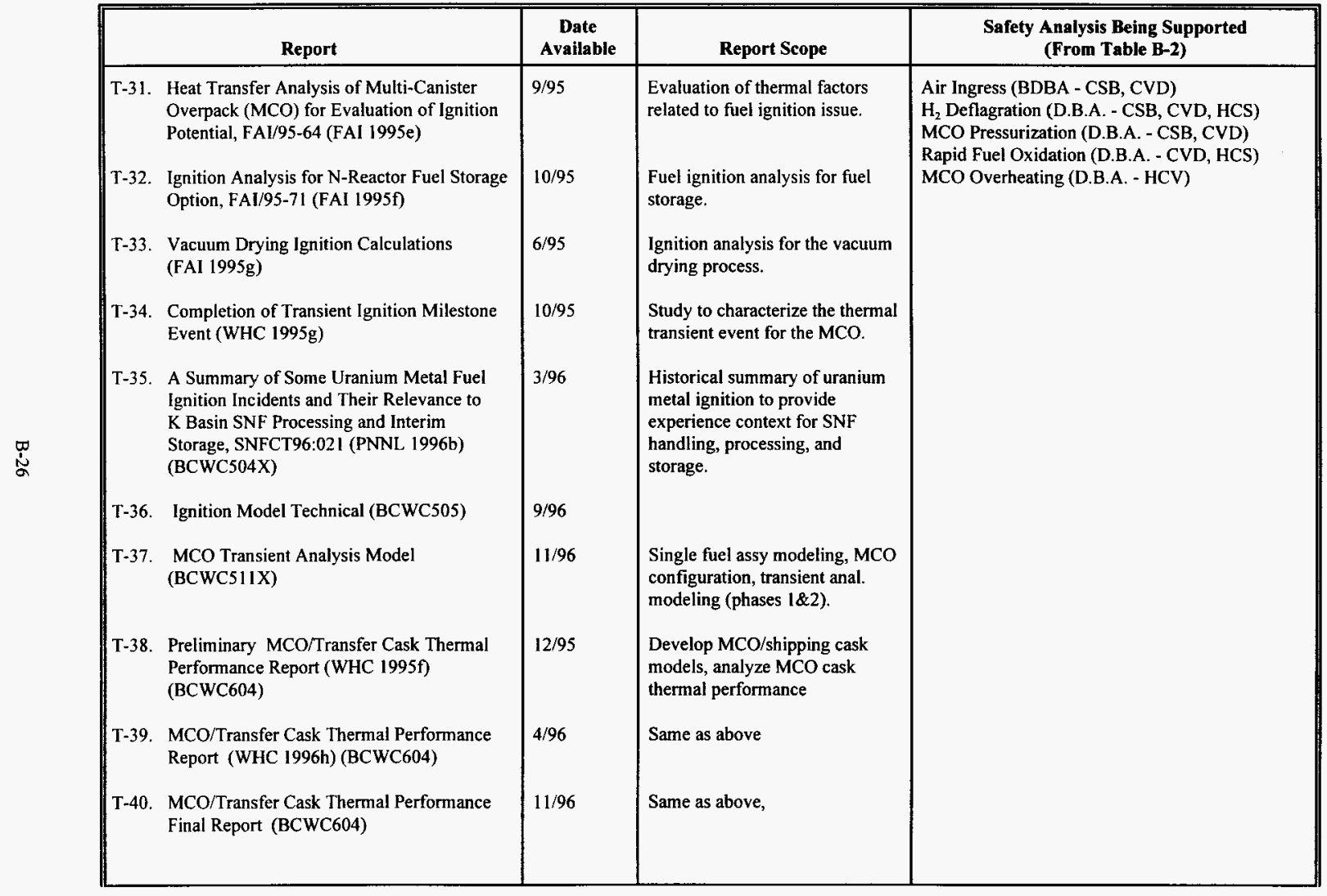


Table B-3. Major Technology Acquisition Reports (7 Sheets).

\begin{tabular}{|c|c|c|c|}
\hline Report & $\begin{array}{c}\text { Date } \\
\text { Available }\end{array}$ & Report Scope & $\begin{array}{l}\text { Safety Analysis Being Supported } \\
\text { (From Table B-2) }\end{array}$ \\
\hline $\begin{array}{l}\text { T-41. Evaluation of MCO Venting and Monitoring } \\
\text { Options During Staging of K Basin Fuel, } \\
\text { WHC-SD-SNF-ES-017 (WHC 1995i) }\end{array}$ & $11 / 95$ & $\begin{array}{l}\text { Explored safety-related issues of } \\
\text { staging in a vented versus a } \\
\text { sealed } \mathrm{MCO} \text {, hydrogen } \\
\text { detonation, gas pressurization, } \\
\text { thermal transients. }\end{array}$ & $\begin{array}{l}\text { Air Ingress (BDBA - CSB, CVD) } \\
\mathrm{H}_{2} \text { Deflagration (D.B.A. - CSB, CVD, HCS) } \\
\text { MCO Pressurization (D.B.A. - CSB, CVD) } \\
\text { Rapid Fuel Oxidation (D.B.A. - CVD, HCS) } \\
\text { MCO Overheating (D.B.A. - HCV) } \\
\text { MCO Release }\end{array}$ \\
\hline $\begin{array}{l}\text { T-42. Desludging of N Reactor Fuel Canister: } \\
\text { Analysis, Test, and Data Requirements, } \\
\text { PNL-10618/UC-510 (PNNL 1996c) }\end{array}$ & $1 / 96$ & $\begin{array}{l}\text { Preliminary definition of data } \\
\text { requirements for } N \text { Reactor fuel } \\
\text { desludging operations in the } \\
\text { K Basins. }\end{array}$ & $\begin{array}{l}\mathrm{H}_{2} \text { Deflagration (D.B.A. - CSB, CVD, HCS) } \\
\text { MCO Pressurization (D.B.A. - CSB, CVD) }\end{array}$ \\
\hline $\begin{array}{l}\text { T-43. Uranium Hydride Formation and Properties: } \\
\text { A Review with Commentary on Handling } \\
\text { and Disposition, SAND96-8206/UC-804 } \\
\text { (SNL 1996) }\end{array}$ & $\begin{array}{l}1 / 96 \\
5 / 95\end{array}$ & $\begin{array}{l}\text { A summary of the practical } \\
\text { experience gained by Sandia } \\
\text { National Laboratories in } \\
\text { handling, transporting, and } \\
\text { storing uranium hydrid. } \\
\text { An evaluation of the issues } \\
\text { related to formation, oxidation } \\
\text { potential, and the effects of } \\
\text { conditioning on uranium } \\
\text { hydride. }\end{array}$ & $\begin{array}{l}\text { Air Ingress (BDBA - CSB, CVD) } \\
\text { Rapid Fuel Oxidation (D.B.A. - CVD, HCS) } \\
\text { MCO Overheating (D.B.A. - HCV) }\end{array}$ \\
\hline $\begin{array}{l}\text { T-45. Thermal Hydraulic Feasibility Assessment } \\
\text { for the Spent Nuclear Fuel Project, } \\
\text { WHC-SD-WM-ER-525 (WHC 1996i) }\end{array}$ & $1 / 96$ & & \\
\hline $\begin{array}{l}\text { T-46. Corrosion of uranium in a Double-Shell Tank } \\
\text { Environment (PNNL 1995) }\end{array}$ & $9 / 95$ & $\begin{array}{l}\text { An evaluation to assess impact } \\
\text { of uranium metal corrosion in a } \\
\text { double-shell tank. }\end{array}$ & Sludge End Point Criteria \\
\hline $\begin{array}{l}\text { T-47. N Reactor Fuel Exposure Characterization in } \\
\text { K Reactor Basin, WHC-SD-SNF-TI-017 } \\
\text { (WHC 1995j) }\end{array}$ & $10 / 95$ & $\begin{array}{l}\text { ALARA assessment for } \\
\text { N Reactor fuel in the } K \text { Basins. }\end{array}$ & Not a basis for D.B.A. \\
\hline
\end{tabular}


Table B-3. Major Technology Acquisition Reports (7 Sheets).

\begin{tabular}{|c|c|c|c|c|}
\hline & Report & $\begin{array}{c}\text { Date } \\
\text { Available }\end{array}$ & Report Scope & $\begin{array}{l}\text { Safety Analysis Being Supported } \\
\text { (From Table B-2) }\end{array}$ \\
\hline T-48. & $\begin{array}{l}\text { N Reactor Fuel Segregation Experience and } \\
\text { Equipment Status (WHC 1995k) }\end{array}$ & $11 / 95$ & $\begin{array}{l}\text { Evaluation of existing } \\
\text { experience and technical base for } \\
\text { segregating } N \text { Reactor fuel. } \\
\text { Estimates the sludge and fuel } \\
\text { segregation issues. }\end{array}$ & $\begin{array}{l}\mathrm{H}_{2} \text { Deflagration (D.B.A. - CSB, CVD, HCS) } \\
\text { MCO Pressurization (D.B.A. - CSB, CVD) } \\
\text { Rapid Fuel Oxidation (D.B.A. - CVD, HCS) } \\
\text { MCO Overheating (D.B.A. - HCV) }\end{array}$ \\
\hline $\begin{array}{l}\text { T-49. } \\
\text { T-50. }\end{array}$ & $\begin{array}{l}\text { K Basins Fuel Decay Heating } \\
\text { Characterization (WHC 1996j) } \\
\text { Assessment of Flour-Daniel Thermal } \\
\text { Approach (WHC 1996k) }\end{array}$ & $\begin{array}{l}12 / 95,1 / 96 \\
3 / 96\end{array}$ & $\begin{array}{l}\text { Establishes preliminary decay } \\
\text { heat contribution to thermal } \\
\text { analysis for the CSB, MCO. } \\
\text { Thermal analysis for the MCO. }\end{array}$ & $\begin{array}{l}\mathrm{H}_{2} \text { Deflagration (D.B.A. - CSB, CVD, HCS) } \\
\text { MCO Pressurization (D.B.A. - CSB, CVD) } \\
\text { Rapid Fuel Oxidation (D.B.A. - CVD, HCS) } \\
\text { MCO Overheating (D.B.A. - HCV) }\end{array}$ \\
\hline T-51. & $\begin{array}{l}\text { Kinetic Data for Oxidation of Zirconium, } \\
\text { Zircaloy, and Stainless Steel (PNNL 1996d) } \\
\text { An Assessment of Getters and Other } \\
\text { Hydrogen Control Technologies for Use } \\
\text { During Pre-Conditioning and Long-Term } \\
\text { Storage of N Reactor Fuels (PNNL 1996e) }\end{array}$ & $\begin{array}{l}1 / 96 \\
3 / 96\end{array}$ & $\begin{array}{l}\text { Establishes reaction rate for } \\
\text { oxidation of MCO material of } \\
\text { construction. Establishes basis } \\
\text { for oxygen gettering estimates. } \\
\text { A comparison of hydrogen } \\
\text { getters and other hydrogen } \\
\text { limiting scenarios. }\end{array}$ & $\begin{array}{l}\mathrm{H}_{2} \text { Deflagration (D.B.A. - CSB, CVD, HCS) } \\
\text { MCO Pressurization (CSB, CVD) }\end{array}$ \\
\hline T-53. & Spent Nuclear Fuel Pyrophoricity & $6 / 96$ & $\begin{array}{l}\text { Documents the preliminary } \\
\text { SNF Project design and safety } \\
\text { bases for pyrophoric reactions in } \\
\text { the MCO. }\end{array}$ & $\begin{array}{l}\text { MCO Pressurization (CSB, CVD) } \\
\text { Rapid Fuel Oxidation (D.B.A. - CVD, HCS) } \\
\text { MCO Overheating (D.B.A. - HCV) }\end{array}$ \\
\hline T-54. & $\begin{array}{l}\text { Surface Area Estimate for Worst Case MCO, } \\
\text { WHC-SD-SNF-TI-TBD }\end{array}$ & $6 / 96$ & $\begin{array}{l}\text { Documents the estimated surface } \\
\text { area for the materials in K East } \\
\text { Basins and a nominal and worst } \\
\text { case for the MCO. }\end{array}$ & $\begin{array}{l}\mathrm{H}_{2} \text { Deflagration (D.B.A. - CSB, CVD, HCS) } \\
\text { MCO Pressurization (D.B.A. - CSB, CVD) } \\
\text { Rapid Fuel Oxidation (D.B.A. - CVD, HCS) } \\
\text { MCO Overheating (D.B.A. - HCV) }\end{array}$ \\
\hline
\end{tabular}


Table B-4. Characterization Reports Supporting Safety Analysis (WHC 1995v) (4 Sheets).

\begin{tabular}{|c|c|c|c|}
\hline Report & $\begin{array}{c}\text { Date } \\
\text { Available }\end{array}$ & Report Scope & $\begin{array}{l}\text { Safety Analysis Being Supported } \\
\text { (From Table B-2) }\end{array}$ \\
\hline 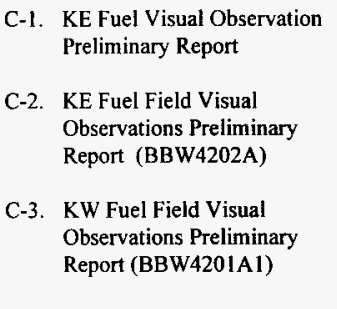 & $\begin{array}{l}2 / 95 \\
6 / 96 \\
9 / 96\end{array}$ & $\begin{array}{l}\text { Video/boreoscope of fuel handling durng } \\
\text { shipping operations. Fuel surface area, fragment } \\
\text { size, entrained deposits. }\end{array}$ & $\begin{array}{l}\mathrm{H}_{2} \text { Deflagration (D.B.A. - CSB, CVD, HCS) } \\
\text { Air Ingress } \\
\text { Radiolysis rates } \\
\text { Reaction Kinetics Model } \\
\mathrm{H}_{2}-\mathrm{O}_{2} \text { Reaction Regimes } \\
\text { MCO Pressurization (CSB, CVD) } \\
\text { Radiolysis Rates } \\
\text { Reaction Kinetics Model } \\
\text { MCO Release } \\
\text { Thermal Hydraulics Flow Model } \\
\text { Aerosol Transport Model }\end{array}$ \\
\hline $\begin{array}{ll}\text { C-4. E Fuel Laboratory Data } \\
\text { Visual Data Report (Related } \\
\text { to BBYA020) } \\
\text { C-5. KW Fuel Laboratory Data } \\
\text { Visual Data Report } \\
\end{array}$ & $\begin{array}{l}10 / 96 \\
3 / 97\end{array}$ & $\begin{array}{l}\text { Initial Lab examinations of fuel shipments } \\
\text { including sectioning and visual observations. Fuel } \\
\text { surface area, entrained deposits, pyrophoric } \\
\text { observations. }\end{array}$ & $\begin{array}{l}\mathrm{H}_{2} \text { Deflagration (D.B.A. - CSB, CVD, HCS) } \\
\text { MCO Pressurization (D.B.A. - CSB, CVD) } \\
\text { MCO Release }\end{array}$ \\
\hline $\begin{array}{l}\text { C-6. KW Fuel Data Interim } \\
\text { Report (WHC 1996l) } \\
\text { C-7. } \\
\text { KW Fuel Data Report } \\
\text { (BBW4304A) }\end{array}$ & $2 / 97$ & $\begin{array}{l}\text { Hydride oxide content, ignition testing, } \\
\text { conditioning testing, oxidation kinetics, energetic } \\
\text { reactions/pyrophoric behavior, } \\
\text { CVD behavior, dry storage behavior, pyrophoric } \\
\text { behavior, oxidation behavior, } \\
\mathrm{H}_{2} \text { evolution, moisture content, thermal behavior. }\end{array}$ & $\begin{array}{l}\mathrm{H}_{2} \text { Deflagration (D.B.A. - CSB, CVD, HCS) } \\
\text { MCO Pressurization (CSB, CVD) } \\
\text { Rapid Fuel Oxidation (D.B.A. - CVD, HCS) } \\
\text { Fuel ignition and reaction kinetics } \\
\text { Empirical data correlations } \\
\text { MCO Overheating (D.B.A. - HCV) } \\
\text { Reaction Kinetics Model } \\
\text { MCO Release }\end{array}$ \\
\hline
\end{tabular}


Table B-4. Characterization Reports Supporting Safety Analysis (WHC 1995v) (4 Sheets).

\begin{tabular}{|c|c|c|c|}
\hline Report & $\begin{array}{c}\text { Date } \\
\text { Available }\end{array}$ & Report Scope & $\begin{array}{l}\text { Sa fety Analysis Being Supported } \\
\text { (From Table B-2) }\end{array}$ \\
\hline $\begin{array}{ll}\text { C-8. } & \text { KE Floor Sludge } \\
\text { Composition Report } \\
\text { (WHC 1996m) } \\
\text { (BBW4801A1) }\end{array}$ & $1 / 96$ & $\mathrm{KE}$ sludge composition analysis. & $\begin{array}{l}\mathrm{H}_{2} \text { Deflagration (D.B.A. - CSB, CVD, HCS) } \\
\text { MCO Pressurization (CSB, CVD) } \\
\text { Rapid Fuel Oxidation (D.B.A. - CVD, HCS) } \\
\text { MCO Release }\end{array}$ \\
\hline $\begin{array}{l}\text { C-9. KE Floor Sludge Evaluation } \\
\text { Report (WHC 1996n) } \\
\text { C-10. KE Canister Sludge } \\
\text { Evaluation Report } \\
\text { (BBW4902AX2) }\end{array}$ & $\begin{array}{l}5 / 96 \\
9 / 96\end{array}$ & $\begin{array}{l}\text { Floor sludge drying behavior, and particle size, } \\
\text { pyrophoric behavior, oxidation behavior, } \mathrm{H}_{2} \\
\text { evolution, moisture content, sludge energetic } \\
\text { reactions, sludge } \mathrm{H}_{2} \mathrm{O} \text { content, sludge CVD } \\
\text { behavior, sludge conditioning behavior, sludge } \\
\text { dry storage behavior, physical properties, } \\
\text { quantity, radiological/radionuclides, energetic } \\
\text { reactions/pyrophoricity, endo- and exothermic } \\
\text { reactions, chemical constituents. }\end{array}$ & \\
\hline $\begin{array}{l}\text { C-11. KE Canister Sludge } \\
\text { Evaluation Report } \\
\text { (BBW4906AX2) }\end{array}$ & $4 / 97$ & & \\
\hline $\begin{array}{l}\text { C-12. KW Canister Sludge } \\
\text { Evaluation Report }\end{array}$ & $5 / 97$ & Same as above & \\
\hline $\begin{array}{l}\text { C-13. KW Floor Sludge Tank } \\
\text { Acceptability Report } \\
\text { (BBW4924A) }\end{array}$ & $9 / 98$ & $\begin{array}{l}\text { Final Tank/SNF sludge compatibility assessment, } \\
\text { Sludge compliance assessment with Tank Farm } \\
\text { Acceptance criteria. }\end{array}$ & \\
\hline
\end{tabular}


Table B-4. Characterization Reports Supporting Safety Analysis (WHC 1995v) (4 Sheets).

\begin{tabular}{|c|c|c|c|}
\hline Report & $\begin{array}{c}\text { Date } \\
\text { Available }\end{array}$ & Report Scope & $\begin{array}{l}\text { Safety Analysis Being Supported } \\
\text { (From Table B-2) }\end{array}$ \\
\hline $\begin{array}{l}\text { C-14. KW Fuel Drying Preliminary } \\
\text { Report (BBW35202A1) } \\
\text { C-15. KE Fuel Drying/Conditioning } \\
\text { Test Report (BBW4605AX) } \\
\text { C-16 KW Fuel Drying Final } \\
\text { Report (BBW4512AX) } \\
\text { C-17. Fuel Dry Storage Report } \\
\text { (BBW4506AX) } \\
\text { C-18. KW Fuel Dry/Load Test } \\
\text { Report (BBW4512AX) } \\
\text { C-19. KW Fuel Dry Storage Test } \\
\text { Report (BBW4521AX) } \\
\text { C-20. KE Fuel Dry Storage Test } \\
\text { Report (BBW4607AX) }\end{array}$ & $\begin{array}{l}7 / 96 \\
6 / 97 \\
8 / 97 \\
9 / 97 \\
8 / 97 \\
2 / 98 \\
2 / 98\end{array}$ & $\begin{array}{l}\text { Fuel sample drying behavior/conditioning testing; } \\
\text { energetic reactions, pyrophoric behavior, CVD } \\
\text { behavior, conditioning behavior, dry storage } \\
\text { behavior, oxidation behavior, } \mathrm{H}_{2} \text { evolution, } \\
\text { moisture content, thermal behavior, sludge } \\
\text { energetic reactions, sludge } \mathrm{H}_{2} \mathrm{O} \text { content, sludge } \\
\text { CVD behavior, sludge conditioning behavior, } \\
\text { sludge dry storage behavior. }\end{array}$ & $\begin{array}{l}\mathrm{H}_{2} \text { Deflagration (D.B.A. - CSB, CVD, HCS) } \\
\text { MCO Pressurization (D.B.A. - CSB, CVD) } \\
\text { MCO Release }\end{array}$ \\
\hline $\begin{array}{l}\text { C-21. KW Fuel TGA Measurement } \\
\text { Report (BBW4514AX) } \\
\text { C-22. KW Fuel TGA Test Report } \\
\text { (BBW4516AX) } \\
\text { C-23. KE Fuel TGA Final Test } \\
\text { Report } \\
\text { C-24. KW Fuel TGA Final Test } \\
\text { Report }\end{array}$ & $\begin{array}{l}8 / 96 \\
8 / 96 \\
6 / 97 \\
9 / 97\end{array}$ & $\begin{array}{l}\text { Limited to furnace data; fuel oxidation } \\
\text { rate/kinetics, bound water release, energetic } \\
\text { reactions/pyrophoric behavior, CVD behavior, dry } \\
\text { storage behavior, pyrophoric behavior, oxidation } \\
\text { behavior, } \mathrm{H}_{2} \text { evolution, moisture content, thermal } \\
\text { behavior. Tests performed on successive fuel } \\
\text { shipments. }\end{array}$ & $\begin{array}{l}\mathrm{H}_{2} \text { Deflagration (D.B.A. - CSB, CVD, HCS) } \\
\text { MCO Pressurization (D.B.A. - CSB, CVD) } \\
\text { Rapid Fuel Oxidation (D.B.A. - CVD, HCS) } \\
\text { MCO Overheating (D.B.A. - HCV) } \\
\text { MCO Release }\end{array}$ \\
\hline
\end{tabular}


Table B-4. Characterization Reports Supporting Safety Analysis (WHC 1995v) (4 Sheets)

\begin{tabular}{|c|c|c|c|}
\hline Report & $\begin{array}{c}\text { Date } \\
\text { Available }\end{array}$ & Report Scope & $\begin{array}{l}\text { Safety Analysis Being Supported } \\
\text { (From Table B-2) }\end{array}$ \\
\hline $\begin{array}{l}\text { C-25. KW Fuel Ignition Test } \\
\text { Preliminary Report } \\
\text { (BBW4503AX) } \\
\text { C-26. KE Fuel lgnition Test Final } \\
\text { Report (BBW40606AX) }\end{array}$ & $\begin{array}{l}8 / 96 \\
6 / 97\end{array}$ & $\begin{array}{l}\text { Highlight reports; KW fuel ignition behavior: } \\
\text { energetic reactions/pyrophoric behavior, } \\
\text { conditioning behavior, dry storage behavior, } \\
\text { pyrophoric behavior, thermal behavior. Highlight } \\
\text { reports issued frequently with only major reports } \\
\text { listed as milestones. }\end{array}$ & $\begin{array}{l}\mathrm{H}_{2} \text { Deflagration (D.B.A. - CSB, CVD, HCS) } \\
\text { MCO Pressurization (D.B.A. - CSB, CVD) } \\
\text { Rapid Fuel Oxidation (D.B.A. - CVD, HCS) } \\
\text { MCO Overheating (D.B.A. - HCV) } \\
\text { MCO Release }\end{array}$ \\
\hline $\begin{array}{l}\text { C-27. KW Fuel Ignition Test Final } \\
\text { Report (BBW4513AX) }\end{array}$ & $9 / 97$ & & \\
\hline
\end{tabular}


Table B-5. Major Process Design Reports (2 Sheets).

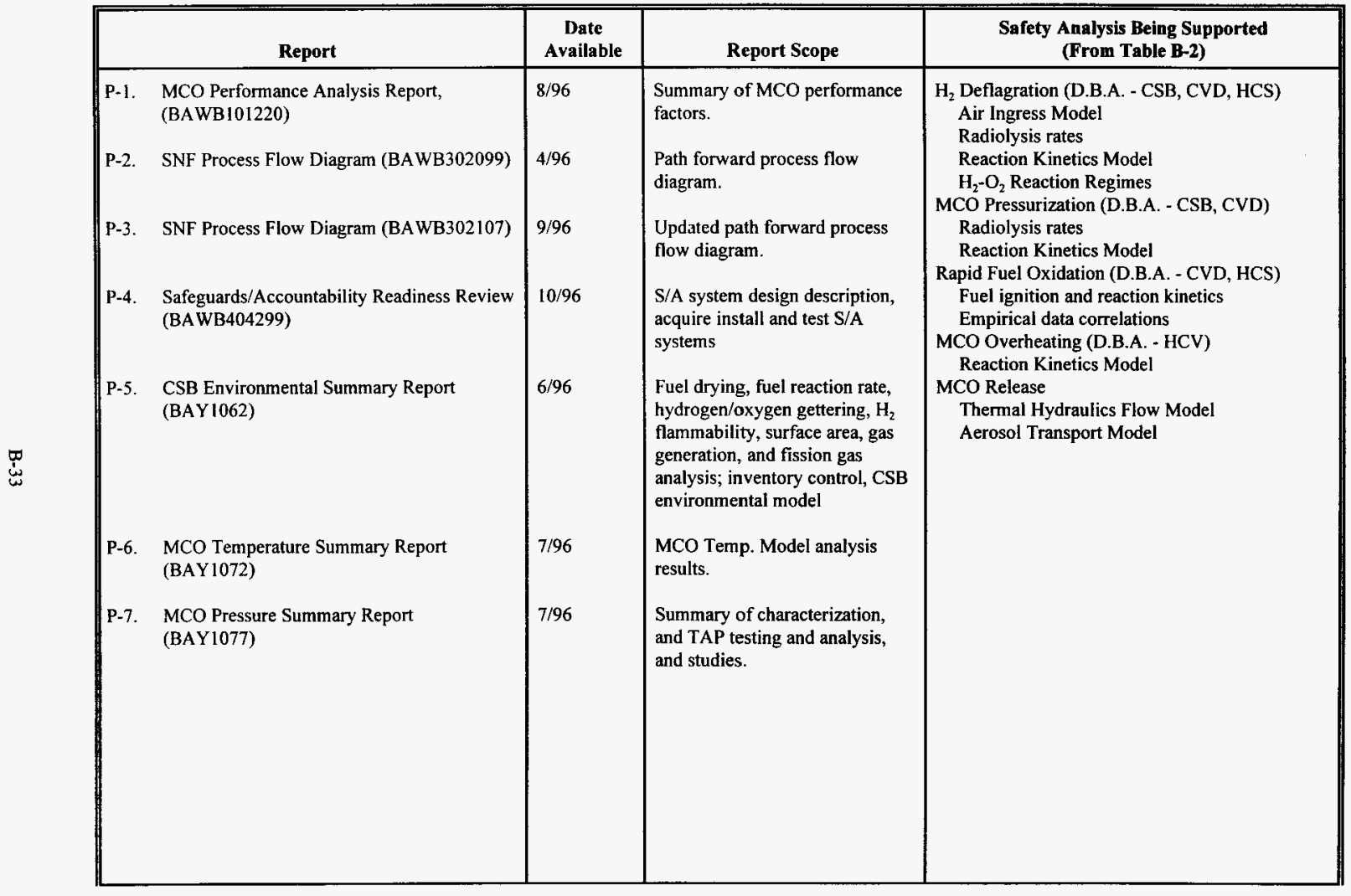


Table B-5. Major Process Design Reports (2 Sheets).

\begin{tabular}{||l|l|l|l||}
\hline \multicolumn{1}{|c|}{ Report } & \multicolumn{1}{c|}{$\begin{array}{c}\text { Date } \\
\text { Available }\end{array}$} & \multicolumn{1}{c|}{ Report Scope } & \multicolumn{1}{c|}{$\begin{array}{c}\text { Safety Analysis Being Supported } \\
\text { (From Table B-2) }\end{array}$} \\
\hline P-8. $\quad \begin{array}{l}\text { Interim MCO Gas Generation/Press } \\
\text { Integrated Report (BAY1087) }\end{array}$ & $6 / 96$ & $\begin{array}{l}\text { Summarize analytic and } \\
\text { modeling data on gas generation } \\
\text { and pressurization technology } \\
\text { issues. }\end{array}$ & $\begin{array}{l}\text { H, Deflagration (D.B.A. - CSB, CVD, HCS) } \\
\text { MCO Pressurization (D.B.A. - CSB, CVD) } \\
\text { Rapid Fuel Oxidation (D.B.A. - CVD, HCS) } \\
\text { MCO Overheating (D.B.A. - HCV) }\end{array}$ \\
P-9. $\begin{array}{l}\text { Final MCO Gas Generation/Press Integrated } \\
\text { Report (BAY 1089) }\end{array}$ & $8 / 96$ & Finalize above report & MCO Release \\
\hline
\end{tabular}




\section{REFERENCES}

FAI, 1995a, Fuel Oxidation and Accident Issue - Technical Basis Background and Status for Hanford Spent Fuel Alternatives, FAI/95-35, Fauske and Associates, Burr Ridge, Illinois.

FAI, 1995b, Preliminary Results of Multi-Canister Overpack Accident Analysis, FAI/95-76, Fauske and Associates, Burr Ridge, Illinois.

FAI, 1995c, Conditioning Process Scoping \& Feasibility Assessment, FAI/95-39, Fauske and Associates, Burr Ridge, Illinois.

FAI, 1995d, Model Description for Canister Conditioning by a Through-Flow Process, FAI/95-53, Fauske and Associates, Burr Ridge, Illinois.

FAI, 1995e, Heat Transfer Analysis of Multi-Canister Overpack (MCO) for Evaluation of Ignition Potential, FAI/95-64, Fauske and Associates, Burr Ridge, Illinois.

FAI, 1995f, Ignition Analysis for N-Reactor Fuel Storage Options, FAI/95-71, Fauske and Associates, Burr Ridge, Illinois.

FAI, 1995g, Vacuum Drying Ignition Calculations, Fauske and Associates, Burr Ridge, Illinois.

Fulton, 1996, Status of Urgent Actions on Spent Nuclear Fuel Project Issues, WHC Letter No. 9601402B R2, (letter to C. A. Hansen, June 14, U.S. Department of Energy, Richland Operations Office), Westinghouse Hanford Company, Richland, Washington.

LATA/SAIC, 1995, The Corrosion of Uranium-Implications for Stabilizing Spent Nuclear Fuel, Paper \#13d, Draft, Los Alamos Technical Associates, Incorporated/Science Applications International, Incorporated, Richland, Washington.

PNNL, 1995, Letter Report on Corrosion of Uranium in a Double-Shell Tank Environment, Pacific Northwest National Laboratories, Richland, Washington.

PNNL, 1996a, Surface Area Consideration for Corroding N Reactor Fuel, Pacific Northwest National Laboratories, Richland, Washington.

PNNL, 1996b, A Summary of Some Uranium Metal Fuel Ignition Incidents and Their Relevance to K Basin SNF Processing and Interim Storage, SNFCT96:021, Revision 0, Pacific Northwest National Laboratories, Richland, Washington.

PNNL, 1996c, Desludging of N Reactor Fuel Canisters: Analysis, Test, and Data Requirements, PNL-10618/UC-510, Pacific Northwest National Laboratories, Richland, Washington. 
PNNL, 1996d, Kinetic Data for Oxidation of Zirconium, Zircaloy, and Stainless Steel, Pacific Northwest National Laboratories, Richland, Washington.

PNNL, 1996e, An Assessment of Getters and Other Hydrogen Control Technologies for Use During Pre-Conditioning and Long-Term Storage of N-Reactor Fuels, Pacific Northwest National Laboratories, Richland, Washington.

SAIC, 1995a, Technical Bases for Assessing Fuel and Sludge Behavior and Gas Release in an MCO During Dry Fuel Storage, Science Applications International, Incorporated, Richland, Washington.

SAIC, 1995b, Materials Guidance for Spent Nuclear Fuel Multi-Canister Overpack, Science Applications International, Incorporated, Richland, Washington.

SNL, 1996, Uranium Hydride Formation and Properties: A Review with Commentary on Handling and Disposition, SAND96-8206/UC-804, Sandia National Laboratories, Albuquerque, New Mexico.

SNL/LLNL, 1995, Hydride Formation, Hydride Oxidation and Conditioning, Sandia National Laboratories/Lawrence Livermore National Laboratories, Albuquerque, New Mexico/Livermore, California.

TRI, 1995, Spent Nuclear Fuel Project Technical lssue Closure Strategy, Technical Resources International, Incorporated, Richland, Washington.

WHC, 1995a, Technology Status in Support of Refined Technical Baseline for the Spent Nuclear Fuel Project, WHC-SD-SNF-TI-014, Rev. 1, Westinghouse Hanford Company, Richland, Washington.

WHC, 1995b, SNF Project Technical Databook, WHC-SD-SNF-TI-015, Westinghouse Hanford Company, Richland, Washington.

WHC, 1995c, K Basin Corrosion Program Report, WHC-EP-0877, Westinghouse Hanford Company, Richland, Washington.

WHC, 1995d, Fuel Corrosion and Gas Evolution During Retrieval, Transportation and WetFuel Staging, Draft, Westinghouse Hanford Company, Richland, Washington.

WHC, 1995e, Reaction Rate Data for Safety Analysis, Westinghouse Hanford Company, Richland, Washington.

WHC, 1995f, Structural Integrity of the Spent Nuclear Fuel Multi-Canister Overpack, WHC-SD-SNF-ES-015, Westinghouse Hanford Company, Richland, Washington. 
WHC, 1995g, Completion of Transient Ignition Milestone Event, Westinghouse Hanford Company, Richland, Washington.

WHC, 1995h, Preliminary MCO/Transfer Cask Thermal Performance Report, Westinghouse Hanford Company, Richland, Washington.

WHC, 1995i, Evaluation of MCO Venting and Monitoring Options During Staging of K Basin Fuel, WHC-SD-SNF-ES-017, Rev. 0, Westinghouse Hanford Company, Richland, Washington.

WHC, 1995j, N Reactor Fuel Exposure Characterization in K Reactor Basin, WHC-SD-SNF-TI-017, Draft, Westinghouse Hanford Company, Richland, Washington.

WHC, 1995k, N Reactor Fuel Segregation Experience and Equipment Status, Westinghouse Hanford Company, Richland, Washington.

WHC, 1996a, SNF Project Integrated Test Strategy (comprehensive test program), WHC-SD-SNF-CM-004, Westinghouse Hanford Company, Richland, Washington.

WHC, 1996b, SNF Project Integrated Test Strategy, WHC-SD-SNF-CM-004, Rev. 1, Westinghouse Hanford Company, Richland, Washington.

WHC, 1996c, Spent Nuclear Fuel Project Detonation Phenomena of Hydrogen/Oxygen in Spent Fuel Containers, WHC-SD-SNF-TI-021, Rev. 0, Westinghouse Hanford Company, Richland, Washington.

WHC, 1996d, Recommended Reaction Rate Constants for Corrosion of N Reactor Fuel, WHC-SD-SNF-TI-020), Westinghouse Hanford Company, Richland, Washington.

WHC, 1996e, Surface Area Estimate for N-Fuel in K East Basin, WHC-SD-SNF-TI-026, Westinghouse Hanford Company, Richland, Washington.

WHC, 1996f, MCO Safety Analysis Assumption Confirmation, Westinghouse Hanford Company, Richland, Washington.

WHC, 1996g, MCO/Shipping Cask Thermal Performance Report, Westinghouse Hanford Company, Richland, Washington.

WHC, 1996h, MCO/Transfer Cask Thermal Performance Final Report, Westinghouse Hanford Company, Richland, Washington.

WHC, 1996i, Thermal Hydraulic Feasibility Assessment for the Spent Nuclear Fuel Project, WHC-SD-WM-ER-525, Westinghouse Hanford Company, Richland, Washington. 
WHC, 1996j, K Basin Fuel Decay Heating Characterization, Rev. 1, Westinghouse Hanford Company, Richland, Washington.

WHC, 1996k, Assessment of Fluor-Daniel Thermal Approach, 74A50-96FJH-008, Fluor Daniel Incorporated, Richland, Washington.

WHC, 1996l, KW Fuel Data Interim Report, Westinghouse Hanford Company, Richland, Washington.

WHC, 1996m, KE Floor Sludge Composition Report, Westinghouse Hanford Company, Richland, Washington.

WHC, 1996n, KE Floor Sludge Evaluation Report, Westinghouse Hanford Company, Richland, Washington. 


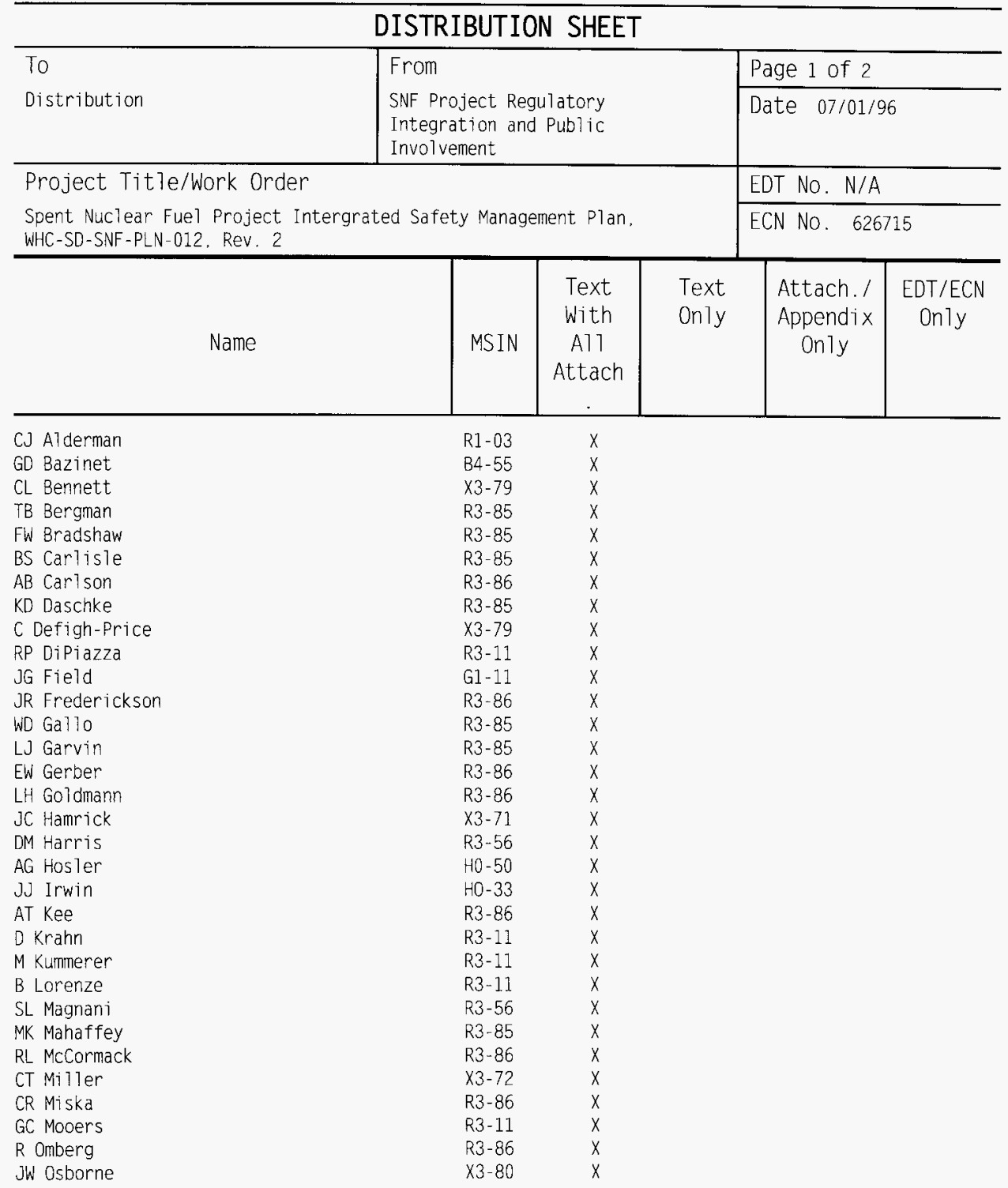




\begin{tabular}{|c|c|c|c|c|c|}
\hline \multicolumn{6}{|c|}{ DISTRIBUTION SHEET } \\
\hline \multirow{2}{*}{$\begin{array}{l}\text { To } \\
\text { Distribution }\end{array}$} & & \multirow{2}{*}{$\begin{array}{l}\text { From } \\
\text { SNF Project Regulatory } \\
\text { Integration and Public } \\
\text { Involvement }\end{array}$} & \multicolumn{2}{|l|}{ Page 2 of 2} \\
\hline & & & & \multicolumn{2}{|l|}{ Date $07 / 01 / 96$} \\
\hline \multirow{2}{*}{\multicolumn{3}{|c|}{$\begin{array}{l}\text { Project Title/Work Order } \\
\text { Spent Nuclear Fuel Project Intergrated Safety Management Plan, } \\
\text { WHC-SD-SNF-PLN-012, Rev. } 2\end{array}$}} & & \multicolumn{2}{|l|}{ EDT No. N/A } \\
\hline & & & & \multicolumn{2}{|c|}{ ECN No. 626715} \\
\hline Name & MSIN & $\begin{array}{l}\text { Text } \\
\text { With } \\
\text { Al1 } \\
\text { Attach }\end{array}$ & $\begin{array}{l}\text { Text } \\
\text { Only }\end{array}$ & $\begin{array}{l}\text { Attach. / } \\
\text { Appendix } \\
\text { Only }\end{array}$ & $\begin{array}{c}\mathrm{EDT} / \mathrm{ECN} \\
\text { Only }\end{array}$ \\
\hline KL Pearce & R3-48 & $x$ & & & \\
\hline SH Peck & R3-85 & $x$ & & & \\
\hline CC Pitkoff & $\mathrm{R} 3-48$ & $x$ & & & \\
\hline JP Schmidt & $\times 3-78$ & $x$ & & & \\
\hline PA Scott & R3-86 & $x$ & & & \\
\hline DW Siddoway & $\times 3-79$ & $x$ & & & \\
\hline EJ Shen & $\mathrm{HO}-40$ & $x$ & & & \\
\hline DW Smith & $\mathrm{R} 3-11$ & $x$ & & & \\
\hline CE Swenson & $58-07$ & $x$ & & & \\
\hline JA Swenson & R3-11 & $x$ & & & \\
\hline DJ Watson & $\times 3-79$ & $x$ & & & \\
\hline JC Wiborg & R3-86 & $x$ & & & \\
\hline MJ Wiemers & $\times 3-85$ & $x$ & & & \\
\hline ME Witherspoon & R3-85 & $x$ & & & \\
\hline JC Womack & R3-86 & $x$ & & & \\
\hline
\end{tabular}

